\title{
The Scars of Sarajevo \& Skenderija's Place
}

by

Sara Beslic

A thesis submitted to the Faculty of Graduate and Postdoctoral Affairs in partial fulfillment of the requirements for the degree of

\section{Master of Architecture}

Azrieli School of Architecture \& Urbanism

Carleton University

Ottawa, Ontario

(C) 2019

Sara Beslic 
// the scars of
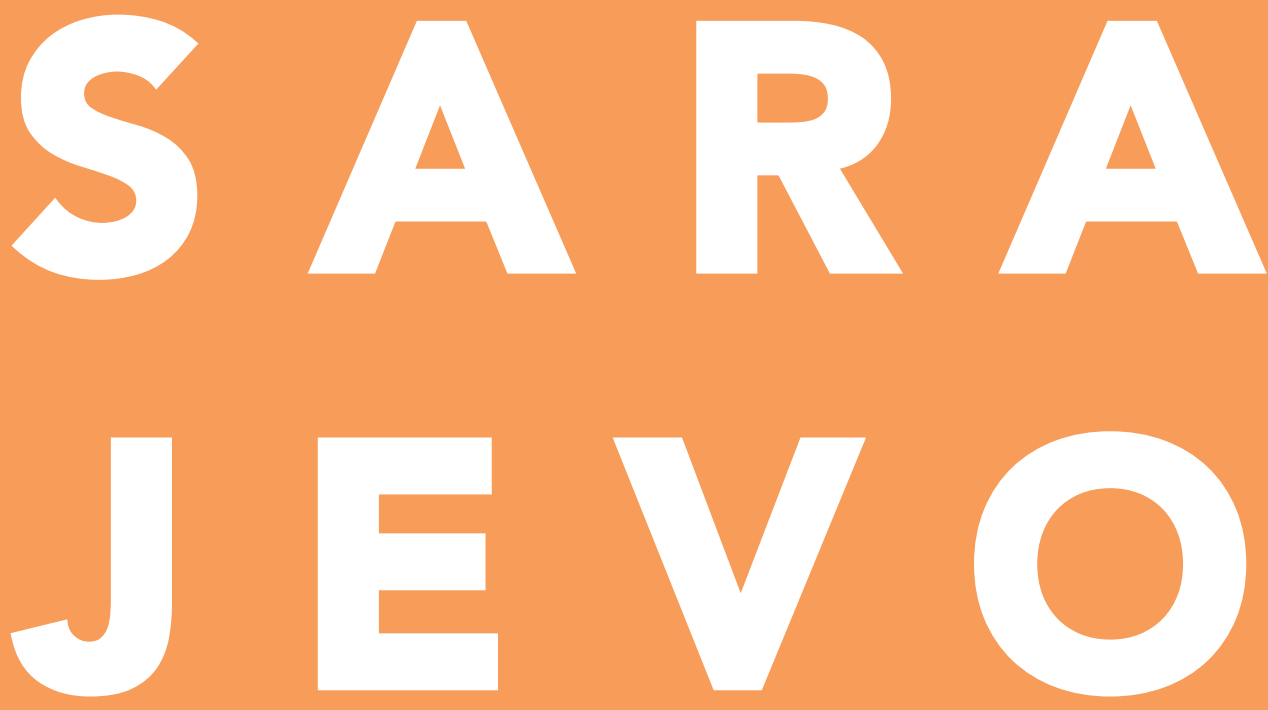

\& Skenderija's place // 

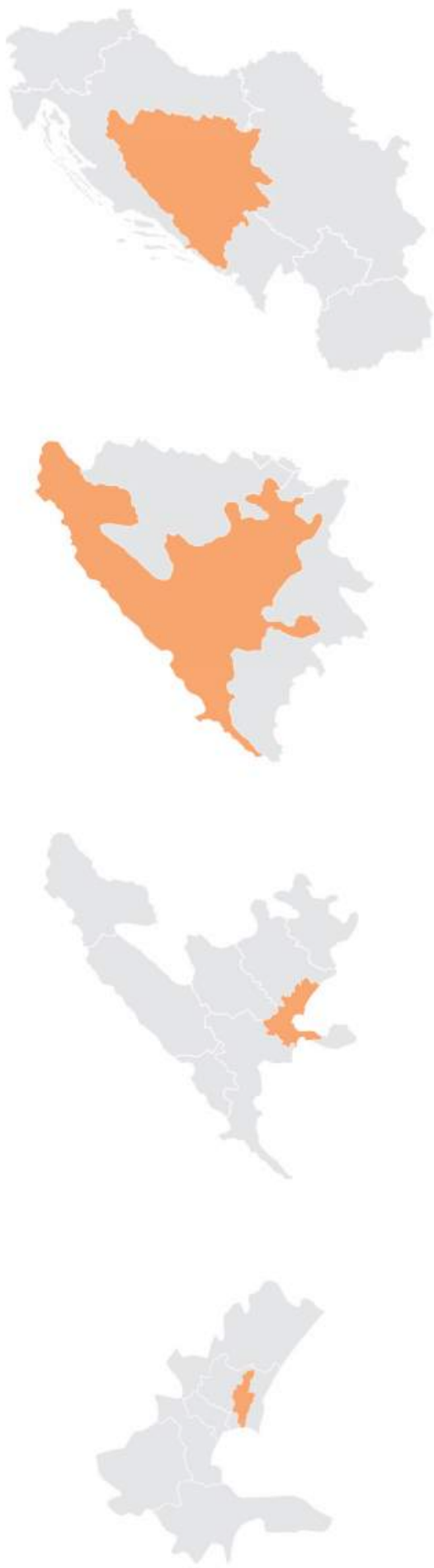


\section{ABSTRACT}

// THE SCARS OF SARAJEVO \& SKENDERIJA'S PLACE

The city of Sarajevo is commonly understood through the lens of two events, almost polar opposites in their effect on the city and its people: the 1984 Winter Olympic Games, unveiling Sarajevo to the rest of the world, and the 1992-1995 Siege of Sarajevo, broadcasted worldwide less than a decade later. This thesis reimagines a central node in the city, hoping to contribute to a rehabilitation of the emotional and physical scars left on Sarajevo. The focus for revitalization of this urban site is Kulturni i Sportski Centar (KSC) Skenderija, one of the 1984 Olympic sites located in the city centre.

Skenderija is a site that pertains to the memory and identity of Sarajevo's citizens as well as to the diaspora who fled during or after the war. To honour the importance of this complex, which no longer connects to the vibrant life that once surrounded it, the design emphasis will be on connective networks between public and recreational spaces, as well as the inclusion of new programs to further post-war recovery. In particular, I plan to draw from the city's distinct cosmopolitan way of living, alongside its prominent layers of architectural history and the contemporary life of the city around festivals and sports. The proposed design focuses on architectural intervention, cultural integration, and social connections. Re-establishing this iconic place of gathering will rescue its identity, creating spaces for the future to unite.

I understand Sarajevo as the place that was my first home, and hope that this project will incorporate the richness and history that I remember. The city's long tradition of living together without separation was damaged by the war, and today's Sarajevans are filled with nostalgia for the strong, confident global city that hosted the Olympic games, celebrating a time of peace and unity. By reinventing the site of Skenderija, I hope to imagine a new future firmly rooted in the city's complex past. 


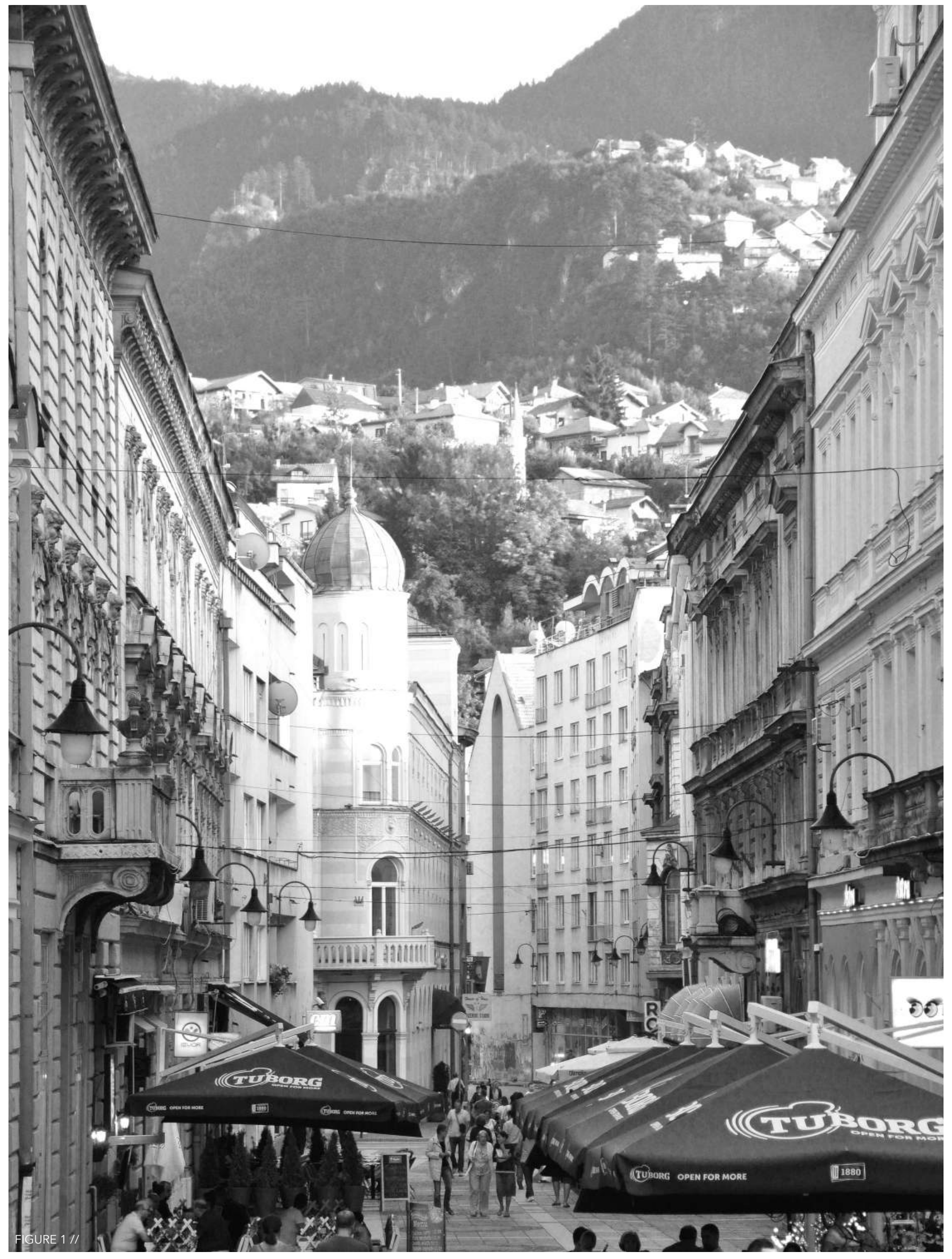




\section{ACKNOWLEDGEMENTS}

// THE SCARS OF SARAJEVO \& SKENDERIJA'S PLACE

To my parents, Bahra and Dragan,

thank you for your courage in revisiting 'memory lane' - nothing I will ever do in life will be harder than what you have endured in yours. Words are insufficient to properly express my gratitude.

To my advisor, Catherine Bonier,

thank you for your constant encouragement and unparalleled guidance throughout this year. You are brilliant and it was my pleasure to be able to work with you.

To my sister, Nina,

thank you for being my first friend and my biggest fan. You always remind me to look at the bigger picture and push me to be better in every way.

To my partner, Alex,

thank you for making sure I took care of myself, and was always well fed and caffeinated. Your unwavering support through this and everything else in life keeps me motivated.

To the rest of my family and friends,

thank you for your reassurance and gentle reminders to take breaks and laugh. You keep me balanced. 


\section{TABLE OF CONTENTS}

// THE SCARS OF SARAJEVO \& SKENDERIJA'S PLACE

ABSTRACT

ACKNOWLEDGEMENTS

iv

TABLE OF CONTENTS

Part 1: Preface

AUTHOR'S NOTE

Part 2: Biography of a City

THE OLYMPIC CITY

25

THE BESIEGED CITY

32

A WAR OVER NAMES

32

A LANDSCAPE OF FEAR

36

RE-APPROPRIATING MEMORY

44

THE STRENGTH OF RESISTANCE

54

THE DIVERSE CITY

67

THE OTTOMAN EMPIRE

67

THE AUSTRO-HUNGARIAN MONARCHY

72

THE SOCIALIST ERA

Part 3: Interpretation of Place

ZAJEDNIČKI ŽIVOT

85

A CULTURAL PROFILE

88

A SOCIAL DIALOGUE

96 
Part 4: Imagination of a Building 108

EVOLUTION OF SKENDER-BEY 109

TITO'S SKENDERIJA 113

OLYMPIC SYMBOLISM 119

Part 5: Cultural Reintegration 125

$\begin{array}{ll}\text { SITE IMPRESSIONS } & 127\end{array}$

CONDITIONAL ASSESSMENT 127

CONTEXTUAL ASSESSMENT 133

SKENDERIJA REACTIVATED 136

SKENDERIJA TAKES CENTRE STAGE 140

$\begin{array}{ll}\text { Conclusion } & 160\end{array}$

Appendices 163

$\begin{array}{ll}\text { GLOSSARY OF TERMS } & 164\end{array}$

PHOTO DOSSIER 171

$\begin{array}{lr}\text { Endnotes } & 172\end{array}$

List of Illustrations 178

$\begin{array}{ll}\text { Bibliography } & 196\end{array}$ 


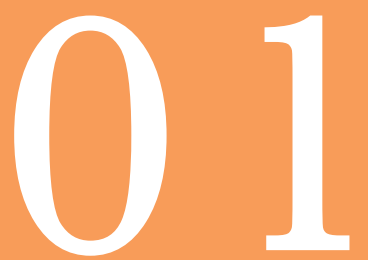

// PREFACE

Author's Note

Pronunciation Guide

Important Dates 


\section{AUTHOR'S NOTE}

// PREFACE

There is no country that has an untroubled past, however Bosnia \& Herzegovina $(\mathrm{BiH})$ is among those with a surplus of history, changes of rule, and permanent consequences. Despite its all too frequent encounters with death, Sarajevo is a city that pulsates with life. Fragmented edges, overlaps and blurring of historical boundaries, the moment you think you're in a city of the East, a few steps forward you'll find yourself on a typical Central European street, surrounded by buildings of differing historical styles. A few more steps and you'll enter an ambient space of contemporary western influences. Although it may appear disjointed at first glance, as you move through Sarajevo, there is a smooth transition between all its moving parts; the multitude of different cultural, social and physical elements combine together and form a cohesive whole.

Geographically it's Sarajevo's position that shaped its destiny. The city formed in a linear fashion, originating at the narrowest end of the valley through the Dinaric Alps and along the Miljacka River, running longitudinally from east to west. The low-lying hills and mountaintops significantly defined the urban layout of the city, allowing modest homes to perch along winding uphill cobblestoned streets. This gave way for the city's commerce and trades to develop centrally on either side of the river. Sarajevo's location allowed the direct possibility for all conquering armies to access its land. Through journeys across Europe, attempts at territorial expansion in this part of the world were common. Centuries of frequently alternating regimes produced a place of diverse cultural and religious fluctuations, each leaving evidence of their traces in an almost chronological order along the valley. An Orthodox church, a cathedral, a mosque and a synagogue are all visible without turning your head, framing the character of the city's 
multicultural state. Sarajevo witnessed the surrender from Ottoman to Austro-Hungarian rule, the assassination of Archduke Franz Ferdinand that instigated the beginning of WWI, the rise and fall of fascism, hosting the 1984 Winter Olympic Games, the rise and fall of socialism, and the horrific siege of Sarajevo in the early 1990s. Throughout all periods of destruction and reconstruction, the only constant remained its diversity.

Sarajevo's diverse existence has made for a complex political landscape that is difficult to understand. The siege of Sarajevo was one of the first wars whose enormous suffering of its people was internationally televised in real time, with live recordings for a global audience. This tragedy violated the shared life once lived by the Socialist Federal Republic of Yugoslavia (SFRY) under the dream of brotherhood and unity, completely disregarding collective memories of the anti-fascist national-liberation and the socialist Yugoslav identity. In what was principally a territorial struggle, the Serbs, Bosnia's second largest ethnic group, violently opposed the country's independence in hopes of creating a 'Greater Serbia'. Sarajevo's amphitheatric appearance with its treasured hills heartbreakingly trapped the Muslim-majority residents of the valley, as the city fell under Serb control. To see a country that hosted an international event of the highest regard uniting disparate nations on its soil, transformed into a country torn apart by its national differences is difficult to comprehend.

The current state of $\mathrm{BiH}$ is separated into two entities, possessing three separate flags, three separate "languages", two separate alphabets, and two national anthems. For most, Former Yugoslavia and the beliefs associated with it appear utopian in nature, a time when everything was better. Coming out of the war as both a post-socialist and a post-conflict society, Sarajevo was moulded once again by another array of drastic transitions. Though it may seem paradoxical in nature, Sarajevo has retained both the charm of a picturesque small town and the attributes of a major cosmopolitan city. If a 
city can truly have a soul, Sarajevo certainly has a formidable one - you may not be able to understand it completely, but you will surely fall in love with it. At the heart of the city, Skenderija sits in need of a transitional period of its own. Intertwined in many ways, Skenderija lies within each Sarajevan's collective memory through the socialist dream of unity and brotherhood, the motivated Olympic nation, the resilient Sarajevans of the siege, and the contemporary neglect of its structures that I hope to address in this thesis. 


\section{PRONUNCIATION GUIDE}

// PREFACE

The language known until 1991 as Serbo-Croatian was the mother tongue of Sarajevo, BiH. Since the separation of Former Yugoslavia, the national language of Sarajevo has trifurcated into three closely related and mutually comprehensible languages: Bosnian, Croatian, and Serbian, otherwise known as the "local" language. Serbian is most frequently utilized in the Cyrillic alphabet, whereas Bosnian and Croatian are written in the Latin alphabet. On occasion, there are as many as five consonants that follow each other without an intervening vowel. Here, the rolled " $r$ " acts as a vowel, and all letters are pronounced in the order in which they are written. This guide presents only those letters that are pronounced differently from the English language and consonants with diacritics.

$\begin{array}{ll}\text { A, a } & \text { a in father } \\ \mathrm{C}, \mathrm{c} & \text { ts in cats } \\ \check{\mathrm{C}}, \check{c} & \text { ch in church } \\ \mathrm{C}, \mathrm{c} & \text { soft ch in watch } \\ \mathrm{D} \check{\text { ż dž }} & \text { j in judge } \\ \text { Đ, d } & \text { j in juice } \\ \mathrm{E}, \mathrm{e} & \text { e in let } \\ \mathrm{G}, \mathrm{g} & \text { hard } \mathrm{g} \text { in go } \\ \mathrm{H}, \mathrm{h} & \text { kh in khan } \\ \mathrm{I}, \mathrm{i} & \text { ee in tee } \\ \mathrm{J}, \mathrm{j} & \mathrm{y} \text { in yes } \\ \mathrm{Lj}, \mathrm{lj} & \text { ll in million } \\ \mathrm{Nj}, \mathrm{nj} & \text { ny as in canyon } \\ \mathrm{O}, \mathrm{o} & \text { o in oats } \\ \mathrm{R}, \mathrm{r} & \text { rolled } \\ \check{\mathrm{S}}, \check{\mathrm{s}} & \text { sh in she } \\ \mathrm{U}, \mathrm{u} & \text { oo in too } \\ \mathrm{Z}, \mathrm{z} & \mathrm{z} \text { in zebra } \\ \check{\mathrm{Z}}, \mathrm{z} \mathrm{s} & \mathrm{s} \text { in pleasure }\end{array}$




\section{IMPORTANT DATES}

// PREFACE

$1400 \mathrm{~s}$

The earliest known name for the large central Bosnian region was Vrhbosna. When Sarajevo is ruled under the Ottoman Empire during its 400-year reign, its official name was Saraybosna, meaning Palace of Bosnia: it is still known by that name in modern Turkish today

Sarajevo city becomes part of the Condominium of Bosnia \& Herzegovina of Austria-Hungary. $\mathrm{BiH}$ fell under Austro-Hungarian rule when the Congress of Berlin approved the occupation

1914 Jun. 28

1914 Jul. 28

1918 Nov. 11

1918 Dec. 01

1939 Sep. 01

1941 Apr. 06

1943 Aug. 30

1945 Apr. 06

1945 Sep. 02

1945 Nov. 29

1956 May 18

1956 Jun. 30

1959 May 03

1960 Oct. [n]

1969 Nov. 29
Gavrilo Princip assassinates Archduke Franz Ferdinand and his wife, Sophie Chotek; the catalyst to World War I

World War I officially begins

World War I officially ends

Constitutional monarchy of Kingdom of Yugoslavia is proclaimed and is ruled by the Karađorđević dynasty

World War II officially begins

German occupation in Yugoslavia begins

Oslobođenje, Sarajevo's main newspaper, is founded Yugoslav Partisans liberate Sarajevo from World War II World War II officially ends

The Socialist Federal Republic of Yugoslavia (SFRY) is proclaimed

Bahra Paralija (author's mother) is born

Dragan Tomić-Bešlić (author's father) is born

Trebević Cable Car is opened. The cable car takes you from the Ottoman Old Town to the top of Trebević Mountain in less than ten minutes

International Theatre Festival MESS is founded under the name of The Festival of Small and Experimental Stages of Yugoslavia. MESS is held every year in Sarajevo KSC Skenderija is ceremonially opened by president Josip Broz Tito 
$1972 \mathrm{n} / \mathrm{a}$

1975 Apr. 06

1978 May 18

$1980 \mathrm{n} / \mathrm{a}$

1980 May 04

1984 Feb. 08

1984 Feb. 19

1989 May 09

1990 Apr. 22

1990 Aug. 29

1991 Jun. 25

1991 Sep. 25

1991 Oct. 08

1992 Feb. 29

1992 Mar. 03

1992 Apr. 05

1992 Apr. 06

1992 Apr. 21

1992 May $[\mathrm{n}]$

1992 May 17

1992 May 18
Academy of Fine Arts opens in the renovated and adapted Austro-Hungarian Evangelical Church, as with the departure of most Evangelicals from Sarajevo at the end of World War I, the church began to lose its need Robna Kuća Sarajka opens. At the time of its construction, this is Sarajevo's showpiece state-owned department store Sarajevo is announced as the host city winner of the 1984 Winter Olympic Games

KSC Skenderija site is expanded to accommodate the provision of figure skating and hockey events: Ledena Dvorana [Ice House] is built

Josip Broz Tito dies

The 14th Winter Olympic Games begin in Sarajevo

The 14th Winter Olympic Games end in Sarajevo

Slobodan Milošević becomes president of Serbia

First multi-party elections for the Yugoslav republics; the communists are defeated in Croatia and Slovenia

Nina Bešlić (author's sister) is born

Slovenia declares independence from Yugoslavia

Macedonia declares independence from Yugoslavia

Croatia declares independence from Yugoslavia

A referendum on independence is held in $\mathrm{BiH}$, with a majority of Muslims and Croats voting in favour, and a majority of Serbs boycotting the vote

$\mathrm{BiH}$ declares independence

Sarajevans march in a peace protest in central Sarajevo. Serbian snipers fire from the upper floor of Holiday Inn, killing 2 civilians

The Siege of Sarajevo officially begins

The Olympic Museum is destroyed overnight, including entire collections of artifacts

KSC Skenderija's Dom Mladih [Youth House] destroyed Sarajevo War Theatre opens

Grenade is launched into the living room of the apartment directly below Bahra and Dragan's, completely destroying it and damaging theirs above. By sheer luck, Bahra, Dragan and Nina were at the neighbour's apartment, across the hall 


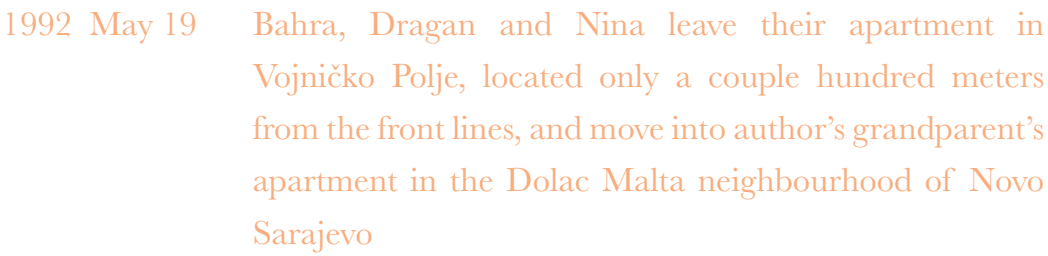

1992 May 25 Olympic Hall Zetra is shelled and destroyed

1992 Jun. 20 Building that houses Oslobođenje Newspaper, Sarajevo's main newspaper, goes up in flames

1992 Jul. 11 Sara Bešlić (author) is born

1992 Aug. 25 Ars Aevi Museum of Contemporary Art is established, serving as a cultural resistance movement during the war Vijećnica (Sarajevo City Hall, housing the famous National and University Library of $\mathrm{BiH}$ ) is set on fire

1992 Aug. 27 Shelling of civilians waiting in line for bread on Ferhadija, killing 3 and injuring 20. This shelling is what sparked the 'cellist of Sarajevo' to play his cello in the street, one day for each victim, showing resistance through art and music Approximately 4:00am, a grenade enters the corner bedroom of the apartment in Dolac Malta, where Bahra, Dragan, Nina and Sara are sleeping. Being only two months old, the author is placed on a separate, makeshift bed of blankets on the floor beside the dresser. The grenade lands a few inches from her head. Grandparents and aunt in the other room, by some miracle, the grenade doesn't explode and no one is injured

1993 Feb. [n] D-B Tunnel below Sarajevo Airport begins construction

1993 May 30 Inela Nogić, 17, is crowned Miss Besieged Sarajevo

1993 Jul, 11 Author turns 1 in Dolac Malta of Novo Sarajevo

1993 Jul. 22

Daily record of shells fired today, totalling 3,777

1993 Jul. 30

D-B Tunnel is completed

1993 Aug. 17 Susan Sontag, prominent American artist, directs the production of Waiting for Godot at the Sarajevo Youth Theatre, performed in the middle of the conflict

1993 Oct. 23 First ever Sarajevo Film Festival begins

1993 Nov. 03 First ever Sarajevo Film Festival ends

1994 Feb. 05 Markale market is targeted by Bosnian Serb Army (BSA). 68 civilians are killed, and 144 wounded. The massacre will be known as the deadliest during the siege of Sarajevo 

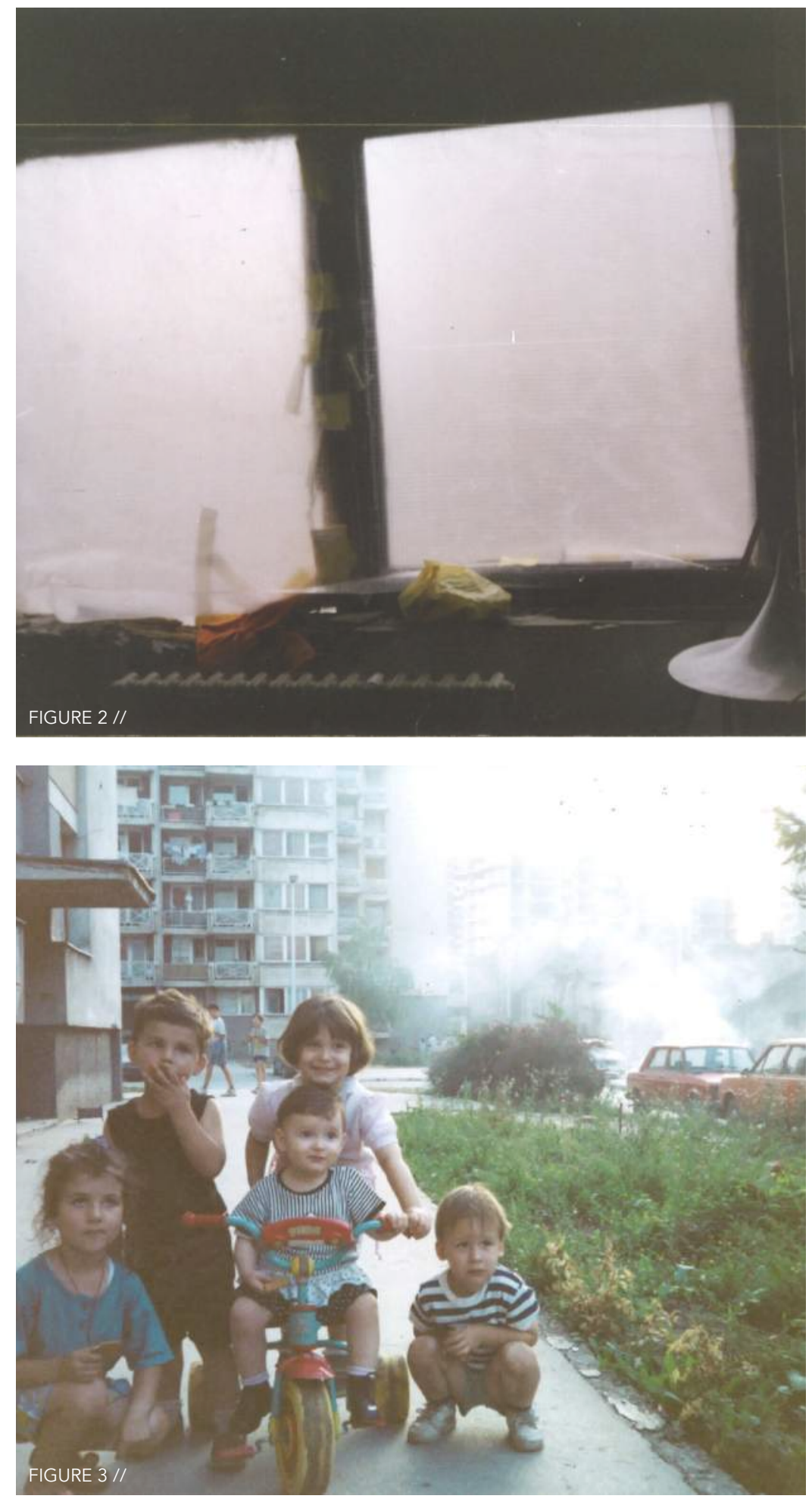

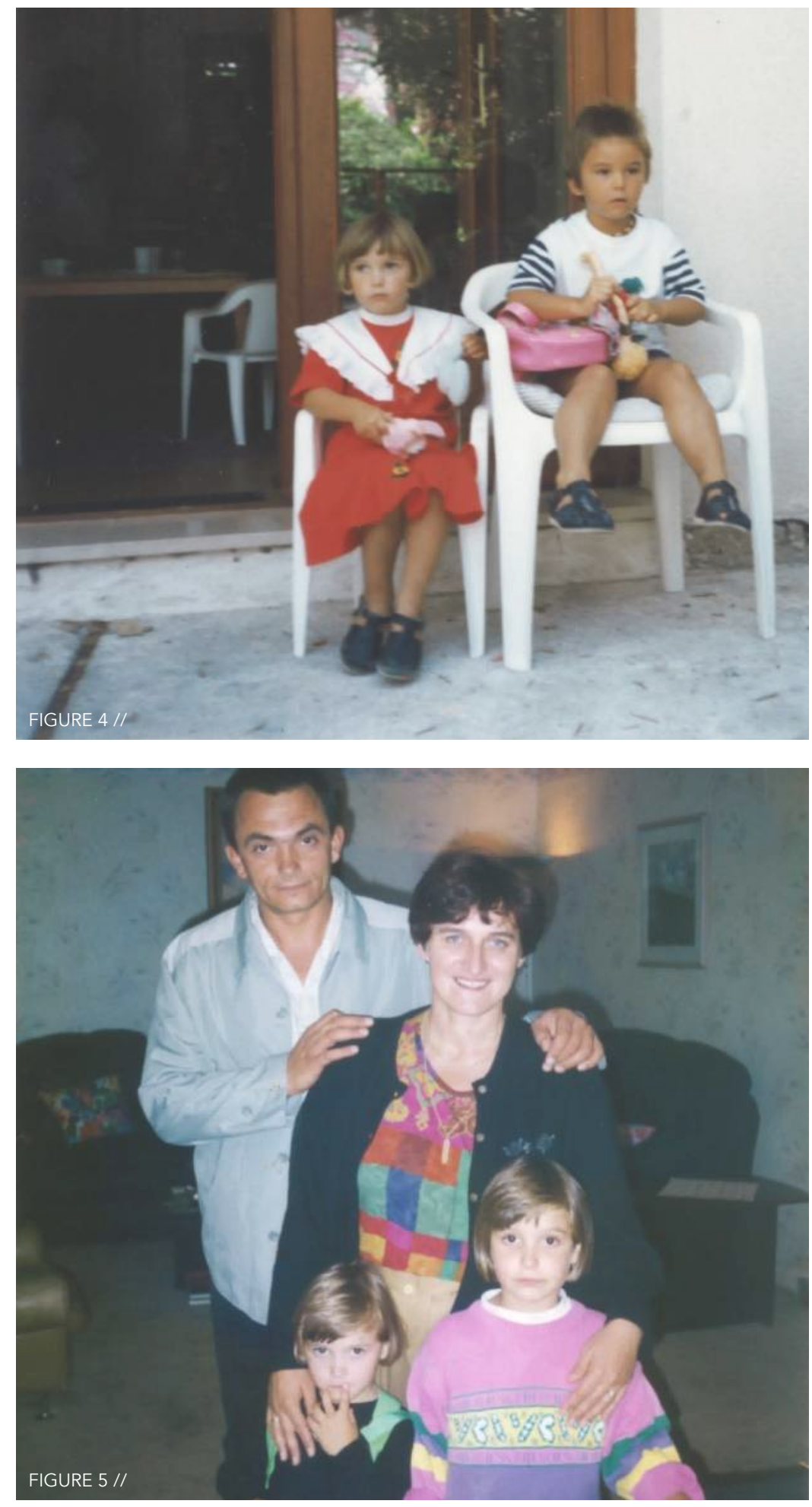
1994 Feb. 28 NATO becomes actively involved, shooting down four Serb aircrafts over central $\mathrm{BiH}$, for violating the United Nations (UN) no-fly zone

1994 Jun. 20 Sarajevo's Orchestra performs Mozart's Requiem in the charred shell of the National Library, conducted by Zubin Mehta

1994 Jul. 11 Author turns 2 in Dolac Malta of Novo Sarajevo

1994 Aug. 10 Bahra, Nina and Sara escape Sarajevo through the D-B Tunnel underneath Butmir Airport. Bahra was granted permission to leave through the tunnel, as all women and children under the age of 5 were allowed to apply for approval papers by legislation. The night was spent in Hrasnica with Bahra's co-worker

1994 Aug. 11 Co-worker arranged a driver to take Bahra, Nina and Sara to Jablanica. The only safe way was to drive through the woods. They stayed at great-aunt Čerima's farm for three days

1994 Aug. 14 Bahra, Nina and Sara wait their turn to get on a bus, passing through Jablanica from other parts of Croatia. They arrive in Makarska, Croatia, staying in the home of Dragan's good friend

1995 Mar. 17 Dragan escapes from his post in the Army of Republic of $\mathrm{BiH}$, on the day of Dragan and Bahra's 5th wedding anniversary

1995 Mar. 18 Dragan arrives in Makarska, Croatia and is reunited with Bahra, Nina and Sara after eight months apart

1995 Jul. 02 UN Headquarters in Sarajevo is shelled by the BSA

1995 Jul. 03 UN convoy on Mount Igman returns fire

1995 Jul. 08 BSA forces move into safe zone of Srebrenica

1995 Jul. 09 BSA forces overrun UN posts in Srebrenica, and take UN troops hostage. UN threatens to call for airstrikes if the BSA doesn't stop

1995 Jul. 11 Author turns 3 on the seaside of Makarska, Croatia

1995 Jul. 11 Srebrenica Massacre begins; more than 8,000 Bosniak boys and men are killed by Bosnian Serb forces

1995 Aug. 28 Markale market is targeted by the BSA for the 2nd time. 38 civilians are killed, and 90 wounded. This was designated to be a safe-zone. NATO responds with bombing 


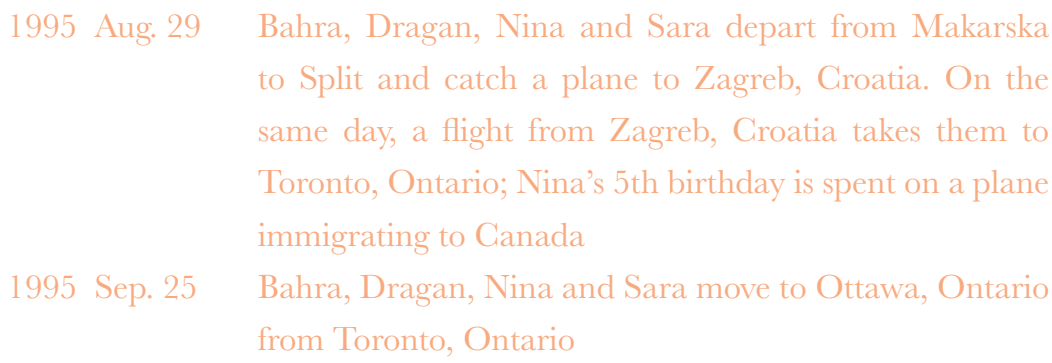

1995 Oct. 12

1995 Oct. 27

1995 Nov. 05

1995 Nov. 21

1995 Dec. 14

1996 Feb. 29

2000 Aug. 15

2002 Feb. 12

2003 Jul. 10

2005 Jun. 24

2006 Mar. 11

2007 Feb. 08

2008 Jul. 21

2008 Jul. 30

2009 Aug. 11

2011 May 31

2012 Feb. 12

2012 Aug. 22

2014 May 09
Brokered by the US, a ceasefire takes effect all over $\mathrm{BiH}$

Second Sarajevo Film Festival begins

Second Sarajevo Film Festival ends

Dayton Peace Agreement reached

Dayton Peace Agreement is signed

BSA forces leave their positions in and around the city of Sarajevo. NATO sends 60,000 peacekeepers to the nation. The Bosnian government officially declares the end of the Siege of Sarajevo

Dragan, Bahra, Nina and Sara return to Sarajevo to visit for the first time since escaping the war

Former Yugoslav President, Slobodan Milošević goes on trial for 66 counts of genocide and war crimes

Dragan, Bahra, Nina and Sara return to Sarajevo to visit Author returns to Sarajevo alone to spend the summer with family before high school

Slobodan Milošević is found dead in his cell at The Hague KSC Skenderija's Dom Mladih reopens after restoration Bosnian Serb wartime president, Radovan Karadzić, responsible for the plan and order of genocide, is arrested Karadzić arrives at the International Criminal Tribunal to face trial for crimes against humanity in The Hague

Bahra and Sara return to Sarajevo to visit

Ratko Mladić, former BSA General known as the Butcher of Bosnia, is extradited to The Hague

KSG Skenderija's Ledena Dvorana roof collapses under weight of heavy snow fall

Festina Lente pedestrian bridge opens, located right in front of the Academy of Fine Arts

Sarajevo iconic National Library, and former City Hall, Vijećnica, reopens after extensive restoration 
2016 Mar. 24 Karadzić is found guilty on 11 counts of war crimes and crimes against humanity and is sentenced to 40 years of imprisonment

2016 Jul. 22 Karadzić files an appeal against his conviction under 'false facts', while The Hague also files an appeal asking to be found guilty of 6 more counts of genocide in other Bosnian municipalities, and lifetime imprisonment

2017 Nov. 22 Mladić is found guilty on 10 counts of war crimes and crimes against humanity, and is sentenced to life in prison. As the top military officer with command responsibility, Mladić is deemed responsible for the Siege of Sarajevo and the Srebrenica massacre

2018 Sep. 05 Author returns to Sarajevo as part of thesis research, not having visited in over nine years

2018 Nov. 16 Dragan's friend sees his old wallet, identity card, and cigarette case in a permanent 'Siege of Sarajevo' exhibit, located at the History Museum of Bosnia \& Herzegovina (Figure 6). These items are placed under the caption of "personal documents and items of victims, stored in the Institute for Emergency Medical Assistance." Having left everything behind at the chance to escape the army, Dragan has no idea how his documents ended up where they did

2019 Feb. 09 European Youth Olympics hosted in Sarajevo begin. Figure skating competitions are held at KSG Skenderija in the main hall

2019 Feb. 16 European Youth Olympics hosted in Sarajevo end 


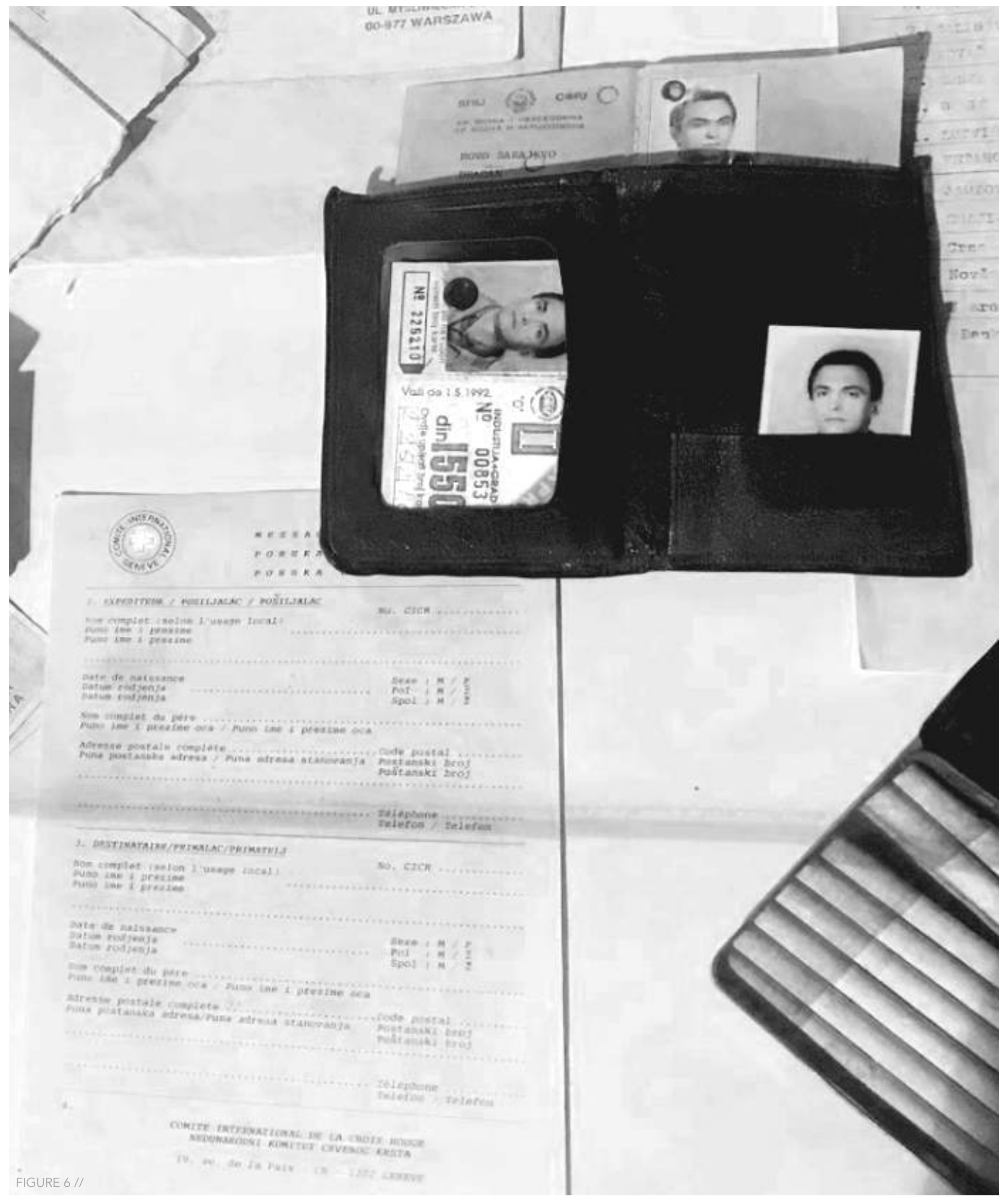




\section{By all accounts it}

was an anomaly, a

\section{hummingbird of a city}

that shouldn't have

existed, but did; the

kind of genuinely multicultural metropolis.

// Kenneth Turan, Sundance to Sarajevo, 92 


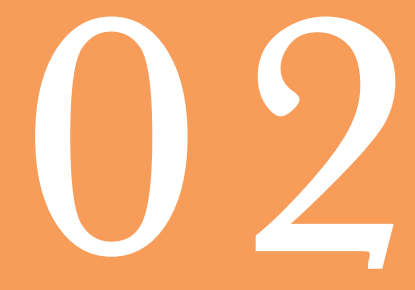

// BIOGRAPHY OF A CITY

The Olympic City

The Besieged City

The Diverse City 


\section{THE OLYMPIC CITY}

// THE OLYMPICS THAT CAPTIVATED THE WORLD

Its success, it could be said, came surprisingly to most who witnessed the Winter Olympic Games in Sarajevo at the start of 1984. Anticipated to be problematic due to the inexperience the country had in this area of urban living, the Olympics that captivated the world were brought together by the united strength of its citizens' love and civic awareness. All Sarajevans combining their efforts to care and love for their city were able to showcase how phenomenal Sarajevo was. On several occasions during the SFRY, $\mathrm{BiH}$ indicated their political, economic and cultural abilities to fall in step with the rhythm of the advancing contemporary world. A predominantly mountainous terrain, $\mathrm{BiH}$ has a unique natural arena of winter sports and tourism playing an integral part in the dynamic life of its people. This especially resonates in Sarajevo where attractive landscapes are conveniently within reach, right from the city centre. The cable car down the street from the Old Town is able to take you to the top of Trebevic Mountain, the winter Olympic venue that hosted the bobsleigh and luge competitions, in just under ten minutes. To have the whole city, from urban city centre to pine forests, lying beneath your feet in such a short period of time is something that very few cities in the world are lucky enough to possess.

In conjunction with its geographic gold, Sarajevo began developing an Olympic corridor in preparation for the events. The construction boom of affordable mass housing throughout the socialist period increased Sarajevo's footprint towards the west, leaving a large portion of land disregarded in the northern direction. As a response, the following strip of land in the northsouth axis was proposed as a green corridor, nicknamed 'ZeTra', or 'zelena transverzala', meaning green transversal. The newly built Zetra Hall, along with this new urban network of green, open spaces, was intended to link the city toward Trebević Mountain. With Skenderija falling directly at the heart 


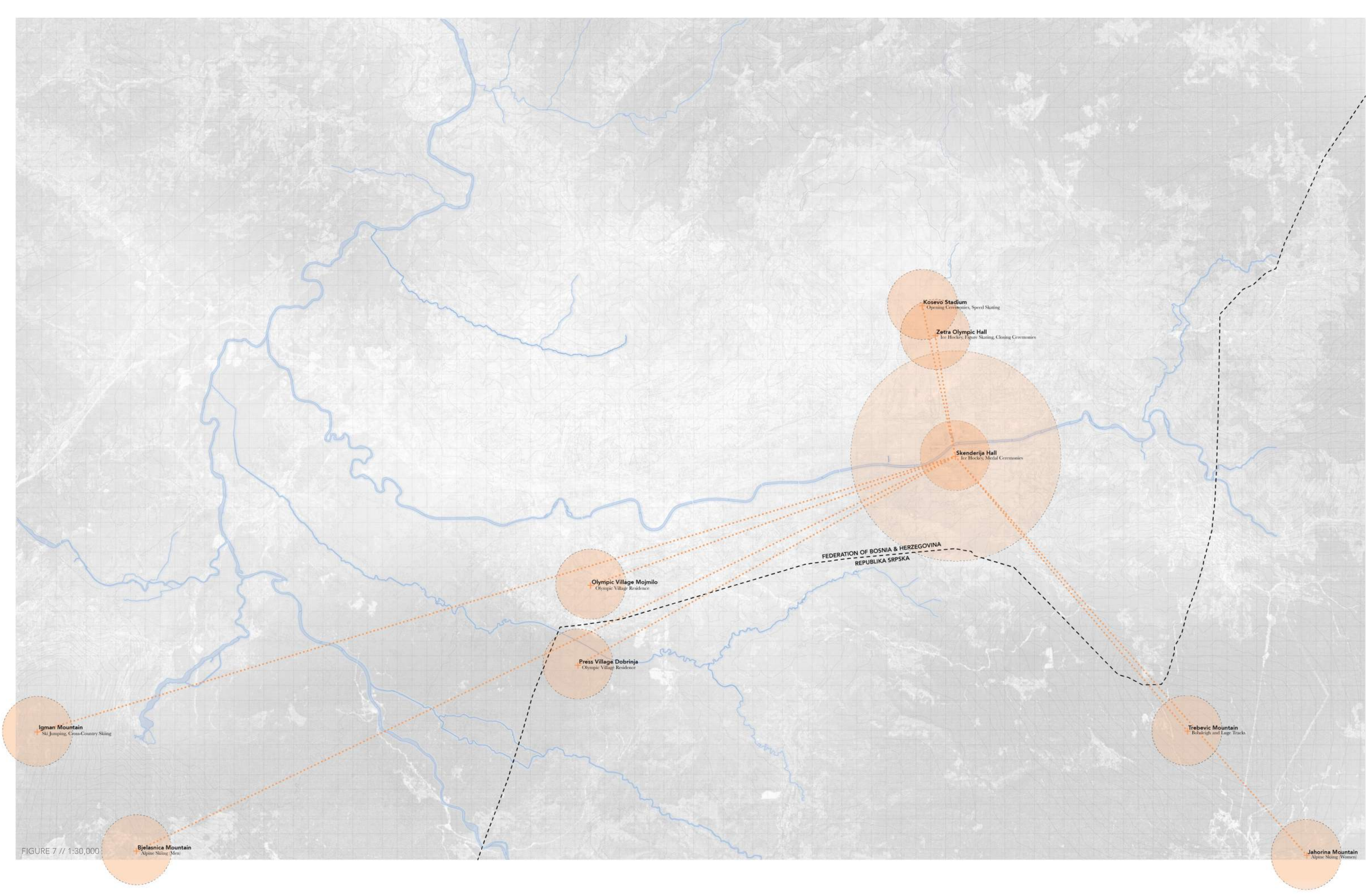


of this axis, an expansion project was planned for a new Ledena Dvorana [Ice House] on its site. With Sarajevo's determination and boldness in accepting such a high calibre event, it implied the confidence in the city's exceptional humans, especially their youth. With over 9,000 youth who got their first jobs in the organization and running of the games, and over 30,000 Sarajevans directly involved in their organization ${ }^{1}$, you could smell the spirit months before; the city was alive day and night. Not only were the 1984 Winter Olympic Games the first to be held in a socialist state, they were also judged to have been the best event of its kind to date, revealing to Sarajevans their own reservoirs of energy and potential, outwardly expressing their character to the rest of the watching world.

The Sarajevo Olympic Games are regarded as a time of tremendous effort and enthusiasm, a time when nothing seemed impossible or unattainable for Sarajevo or any of the SFRY republics. It was the pride and joy for all of Yugoslavia. Visitors at the time collectively remarked the atmosphere of order and politeness that prevailed, adorning the newspapers with abundant words of praise and creating lasting impressions to whomever they came into contact with. "A gold medal should be given to all of the citizens of Sarajevo," ${ }^{2}$ wrote one foreign journalist, reflecting on his time spent in the city. By some accounts, Sarajevans were almost too hospitable: taxis drove around town for free, waiters refused to accept tips, shopkeepers in the Old Town toasted customers with homemade brandy, sometimes handing out cigarettes, and shops, restaurants or banks all simply worked as long as was necessary, not following their fixed schedules. Most notably, those visitors who came to town without reserving accommodations in advance were not rendered homeless, as they would find themselves taken in by a local and welcomed as an expected guest in their home. Sarajevans were touching hearts with every encounter, that directly following the end of the games, more than 10,000 letters or messages of some kind were received by the Organization Committee - in them, expressing their admiration and delight from all corners of the globe. ${ }^{3}$ 

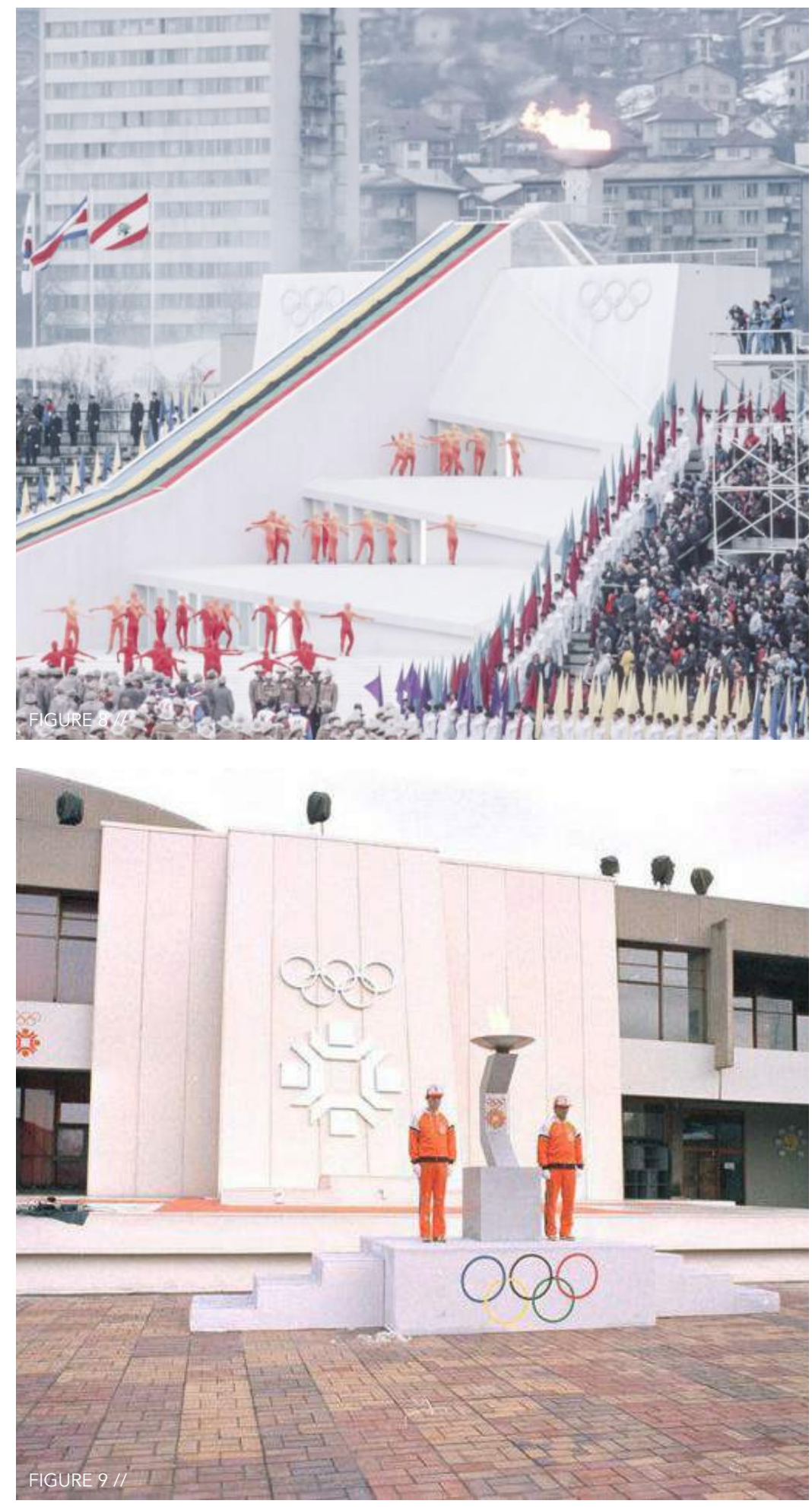


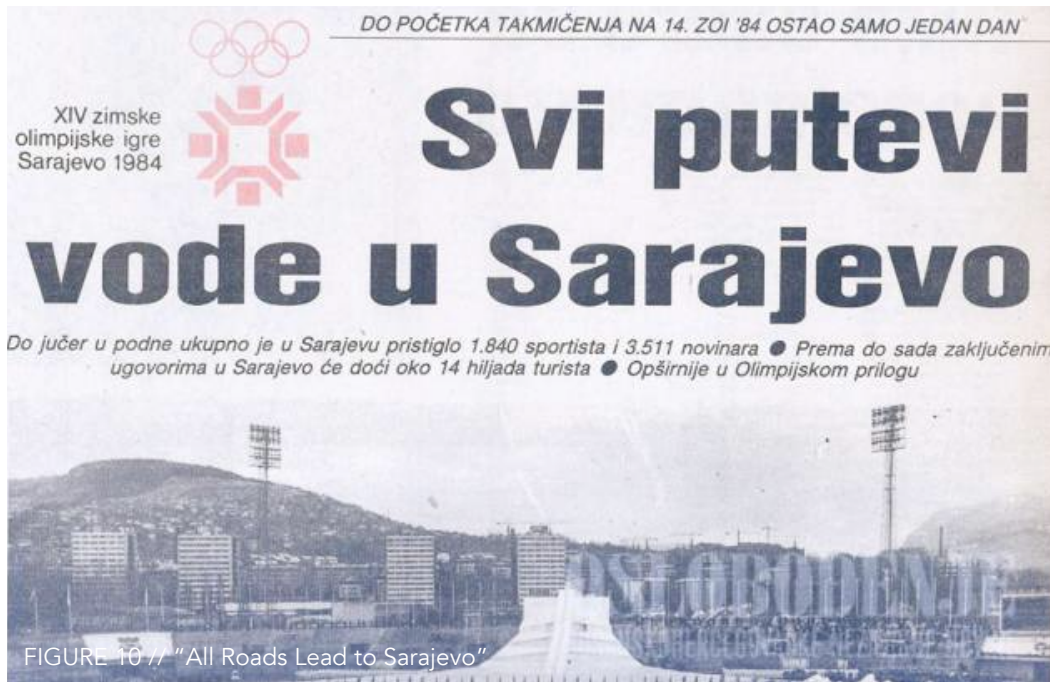

From: Elaine B. Allaine,

Via del Monte, Palas Verdes Estates,

California, 90274, USA

Addressed to: unknown Sarajevo friends

"...You have opened many eyes all over the world and warmed many hearts. Personally, I will never forget Sarajevo..."

After all that was said and done, the success of Sarajevo's future following the 1984 Olympic Winter Games was evident. "The realization of its ambition to become a recognized and famous centre for winter and continental tourism" was well on its way. Sarajevo had outdone itself in a wonderful way, redefining culture, urbanity and emotion for the human scale.

Following the closing fanfares of the Olympic games, Sarajevo was able to climb this ascent for less than a decade before its cruel and horrific descent into destruction began. During the four-year long Siege of Sarajevo, beginning in 1992, cemeteries located outside of the city became unsafe and forced Sarajevans to bury and honour their dead by searching for any available spaces within the city. With nowhere else to go, playgrounds, 
soccer fields and parks were all reappropriated into cemeteries, symbolizing the city's desperation. Among these, Koševo Stadium, home to the opening ceremonies of the Olympic games, was pressed into service as a graveyard. Beauty, honour, peace and optimism, everything that signified what was generously offered in 1984, was taken away by the atrocities of war and nationalistic madness.

Today, Sarajevo still fondly recalls the highly successful time of the 1984 Winter Olympic Games with pride and nostalgia, a time of courage and achievement. Sarajevans are highly attached to the games as they belonged to everyone, regardless of religion and ethnicity; no one cared what your name or ethnic composition was, all that mattered was that the entire country, each individual republic, came together to produce such a successful event. In 2001, Debbie Armstrong, an American gold medalist returning to Sarajevo with a non-profit organization, brought her medal with her. When she met the mayor and handed it to him she was not expecting this thoughtless action to move him to tears, but he just stood there and cried. To him it symbolized "this glorious time of peace and togetherness that'll never happen again." Ismet Huseinovic, a coppersmith working in Baščaršija, agrees that there has never been and will never again be such an event in the city of Sarajevo. "By hosting the games, we defended the city's honour, and not just the city's honour, but the honour of Yugoslavia. We were all in it together." ${ }^{\prime 6}$ Presently, the distant Olympic memories and the bitter experiences of destruction and bloodshed overlap in the collective consciousness of Sarajevans. How such a horrific war of divisions could occur less than a decade after such a beautiful display of unity remains a thought in the back of all minds. This thesis imagines the reuse of the Olympic corridor through the reintegration of Skenderija's Ledena Dvorana and plateau. The potential for rehabilitating its centrally located open space for communities to come together is an initiative that could restore the pride and communal spirit of the Olympic games, presently sitting dormant in the city's collective memory. 
There's no country he can go to where he won't be from Sarajevo. This is his home, and this is the city he wants to be in. He doesn't want to live under siege for the rest of this life, but to abandon the city to the men on the hills would mean that he would be forever homeless. 


\section{THE BESIEGED CITY}

\section{// A WAR OVER NAMES}

In 1990, six years after the end of the winter Olympic games that put Sarajevo on the map and into everyone's hearts, and ten years after the death of President Josip Broz Tito, the first multi-party elections were held for the Yugoslav republics. The first republic to declare independence was Slovenia, quickly followed by Croatia and Macedonia. The separation of republics up until this point was achieved with little resistance, due to the religious beliefs and uniform ethnic compositions of their residents. Without knowing it at the time, this would not be the case for BiH. In March of 1992, BiH declared independence and was internationally recognized the following month - the same month that the "medieval siege in the service of modern nationalism"1 was forced upon Sarajevo. The intent of division along its ethnic lines was stated clearly and publicly; the city and its people were held hostage as a means of coercing BiH's political leaders into agreement, and their architecture and urban spaces were appropriated as a means of achieving this.

Sarajevo, BiH's capital city, is a place known to people of various cultures and confessions harmoniously living intermingled for centuries. It is the city in all the Yugoslav republics that is least to blame for the country's collapse, yet was put under attack as if "the idea of coexistence itself was now marked for destruction."2 The siege of Sarajevo was the beginning of a reign of terror that would go on for 1,425 days, making it the longest siege of a city in modern history. The proportion of innocent civilians affected by war rose from $10 \%$ of casualties in World War I, to $50 \%$ of casualties in World War II, to $90 \%$ in $\mathrm{BiH}^{3}$; the opportunity to die was everywhere. The Bosnian Serb Army (BSA) would shoot at anyone simply trying to cross the street. Whether you were an unarmed man, woman, or child didn't matter, its aim was to terrorize its residents and spread fear. They weren't trying to 
kill a person; they were trying to kill the city. The Sarajevans that remained in the city or were not taken away to detention camps lived without much that we would consider to be 'essential'. They endured the horrific and exhausting shelling and sniping that lasted more than 46 months without free-flowing water, electricity or food. Every tree within the city was cut down for firewood in the first few months of the siege; if there was ever water or electricity, it would be turned on for less than an hour, months apart, and never at the same time; and there was so little food that the average person lost 25 pounds. To some extent, the besieged Sarajevo "operated as a giant concentration camp in which citizens were confined, controlled, and oppressed." A A common 'joke' shared by Sarajevans about the living conditions of the siege was that, unlike Auschwitz where poisonous gas was the main extermination method, its absence in Sarajevo was because the BSA had turned off the city's infrastructure.

Prior to the Bosnian war, the city of Sarajevo was the headquarters for all Muslim communities in the SFRY, but it was equally the seat of the Serbian Orthodox metropolitan and a Roman Catholic archbishop. There was no separate Croat quarter, Serb quarter or even Jewish quarter because all communities overlapped one another; statistically, "a third of the residents were even products of interethnic marriages." "It was Slobodan Milošević, the newly elected Serb nationalist president that had a vision for a 'Greater Serbia'. This was to be known as the creation of a Serb state encompassing all regions of traditional significance to Serbs and all regions outside of Serbia that were populated by Serbs. This ideology included the supposed re-claiming of its own territories in modern day $\mathrm{BiH}$, inspired by the memory of a powerful Serbian Empire that existed preceding the Ottoman conquest of the Balkans.

As Tito's vision was the unification of the south Slavic countries, which promised a new era of brotherhood and unity, the conflict that occurred throughout former Yugoslavia following his death has often been lazily viewed 


$\begin{aligned} \mathbf{5 0 0}, \mathbf{0 0 0} & \text { city population } \\ \mathbf{5 0 \%} & \text { Bosniaks (Muslims) } \\ \mathbf{2 5 \%} & \text { Bosnian Serbs (Orthodox) } \\ \mathbf{7 \%} & \text { Bosnian Croats (Catholic) } \\ \mathbf{1 3 \%} & \text { Yugoslavs } \\ \mathbf{5 \%} & \text { Jews and "others" }\end{aligned}$

256 days without water in 1st year of siege 288 days without electricity in 1st year of siege 1, 425 total days of terror

$\begin{aligned} \mathbf{1 1}, \mathbf{5 4 1} & \text { Sarajevans killed } \\ \mathbf{5 6 , 0 0 0} & \text { Sarajevans wounded } \\ \mathbf{1 5 0 , 0 0 0} & \text { Sarajevans turned refugees } \\ \mathbf{3 2 9} & \text { average number of grenades a day } \\ \mathbf{3 , 7 7 7} & \text { recorded high of grenades in one day } \\ \mathbf{1 , 0 0 0} & \text { grenades launched at hospitals in 1st year } \\ \mathbf{1 2 0 , 0 0 0} & \text { approximate total number of grenades }\end{aligned}$

$\begin{aligned} 24,000 & \text { apartments totally demolished } \\ 35,000 & \text { apartments heavily damaged } \\ \mathbf{2 3} \% & \text { buildings destroyed } \\ 64 \% & \text { buildings damaged }\end{aligned}$


as the continuation of centuries-old conflict re-emerging once his carefully instituted system of checks and balances came to an end. Although conflict existed, Tito's vision wasn't a utopian thought. "The physical evidence, the regions heterodox architectural heritage, was equally a material testimony to coexistence." ${ }^{\prime 6}$ It was Milošević, knowing the Bosnian Serb population to be the most prominent of the republics outside of Serbia itself, who sought after his interests of a 'Greater Serbia.' Ordinary people did not want this division, as it wouldn't make anyone from any faith happy. The legacy of a mix of faiths and shifting empires with the architecture to go along with it, made Sarajevans intensely proud of its modern, multi-ethnic presence in the western world. However, it was this exact modernism of Sarajevo that shocked television viewers witnessing the city's descent into chaos. "Here were a people and a city, recognizably European and cultured, unravelling into barbarism." 
The geography of the siege was simple: Sarajevo is a linear city that formed on a long ribbon of flatland, surrounded on all sides by the Dinaric Alps. In April of 1992, the country's Serbs, who were backed by Milošević, began claiming large chunks of territory throughout the city. They took position at level ground in Grbavica, situated in the middle of the city, and at high ground atop the mountains. The proximity of their elevation was startling; these were the same mountains that once hosted the 1984 Winter Olympic Games and that allowed Sarajevo's glorious coming-out party to the rest of the world. A short eight years following, these same mountains enabled the BSA to encircle the city, firing bullets and mortars, tank shells and grenades, which were all being defended by one tank and small handheld weapons. It isn't difficult to understand: the city was being destroyed. Sarajevo's topography, “its source of astonishing beauty, also became its greatest curse."

The main road, Zmaja od Bosne, runs through the city parallel to its spine, the Miljacka River. Throughout the siege, this street adopted the name Sniper's Alley, which to locals was laughable - it took foreigners and journalists from the airport to the Holiday Inn, standing out as a particularly dangerous intersection to them. Of course in reality it seemed as though every single street in Sarajevo could have had this name, and if by some "act of magnificence there was a street that was impenetrable to the men on the hills, to single that street out for a special name." 9 The landscape of fear established by sniping (Figures 13-24) was a form of infrastructural terrorism aimed towards the traffic networks and flows of movement as a means of paralyzing the city, whereas shelling was aimed at "crowds in urban spaces as a means of denying the public gathering and encountering of residents of different ethnicities." 10 The targeting of mundane places 







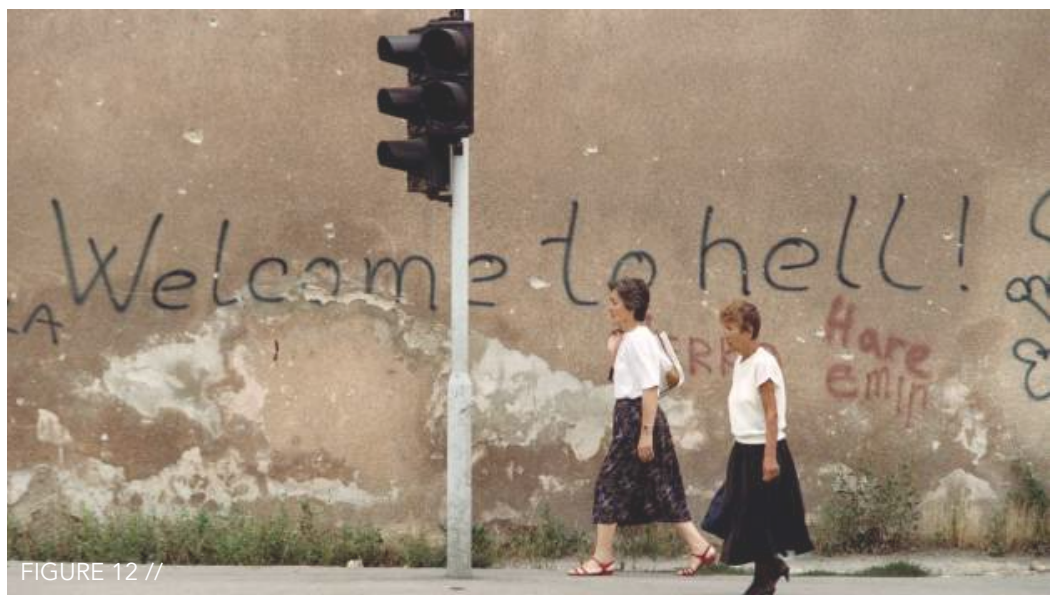

such as hospitals, schools, playgrounds, parks and cemeteries during funerals are some of the most horrifying aspects of this siege. Violence and terror transformed Sarajevo's urban space into a network of danger zones in which anyone at any time was a moving target. Even vulnerable inside their homes, Sarajevans were getting killed by sniper bullets going through their apartment windows. It was an environment for which no one had any previous experience in helping, how could anyone be prepared to see a modern, industrialized country descend into this horror?

It wasn't until the end of 1995 that NATO military action ended the war. Bosnians were ultimately unable to make any progress throughout the siege due to poor weaponry and the significant differences in military power between the two armies. With the BSA being backed by Milošević, they were the clear superiors, and aggressors to Sarajevo's asymmetric warfare. Despite this, the UN elected to treat the conflict as a 'civil war', prohibiting weaponry from entering into $\mathrm{BiH}$ under the assumption that this would escalate the conflict. Being an organization designed to avoid war in order to maintain peace, UN troops on the ground instead provided humanitarian aid to the civilians and supervised both sides without interfering in the fighting, except in the case of direct attacks on UN collateral. ${ }^{11}$ Under these circumstances, in 1993 the UN declared six 'safe zones' where fighting was supposed to cease and protect the population; this was proven ineffective 

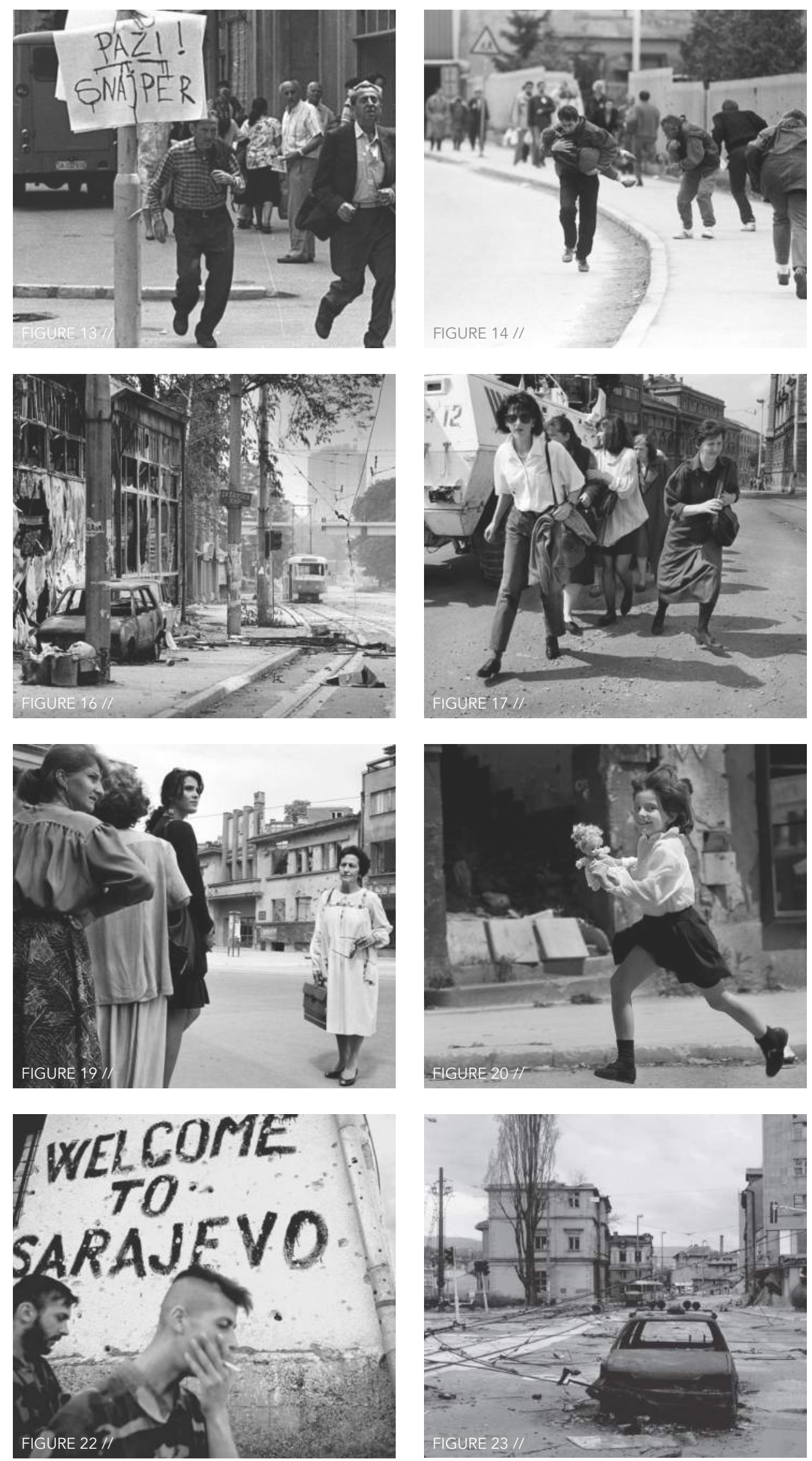
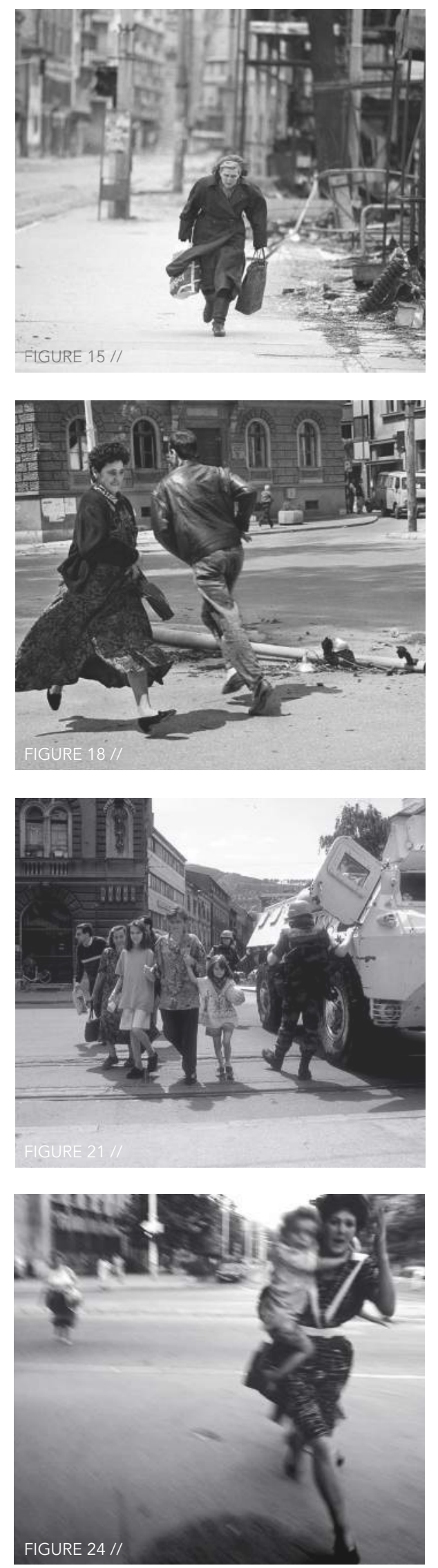

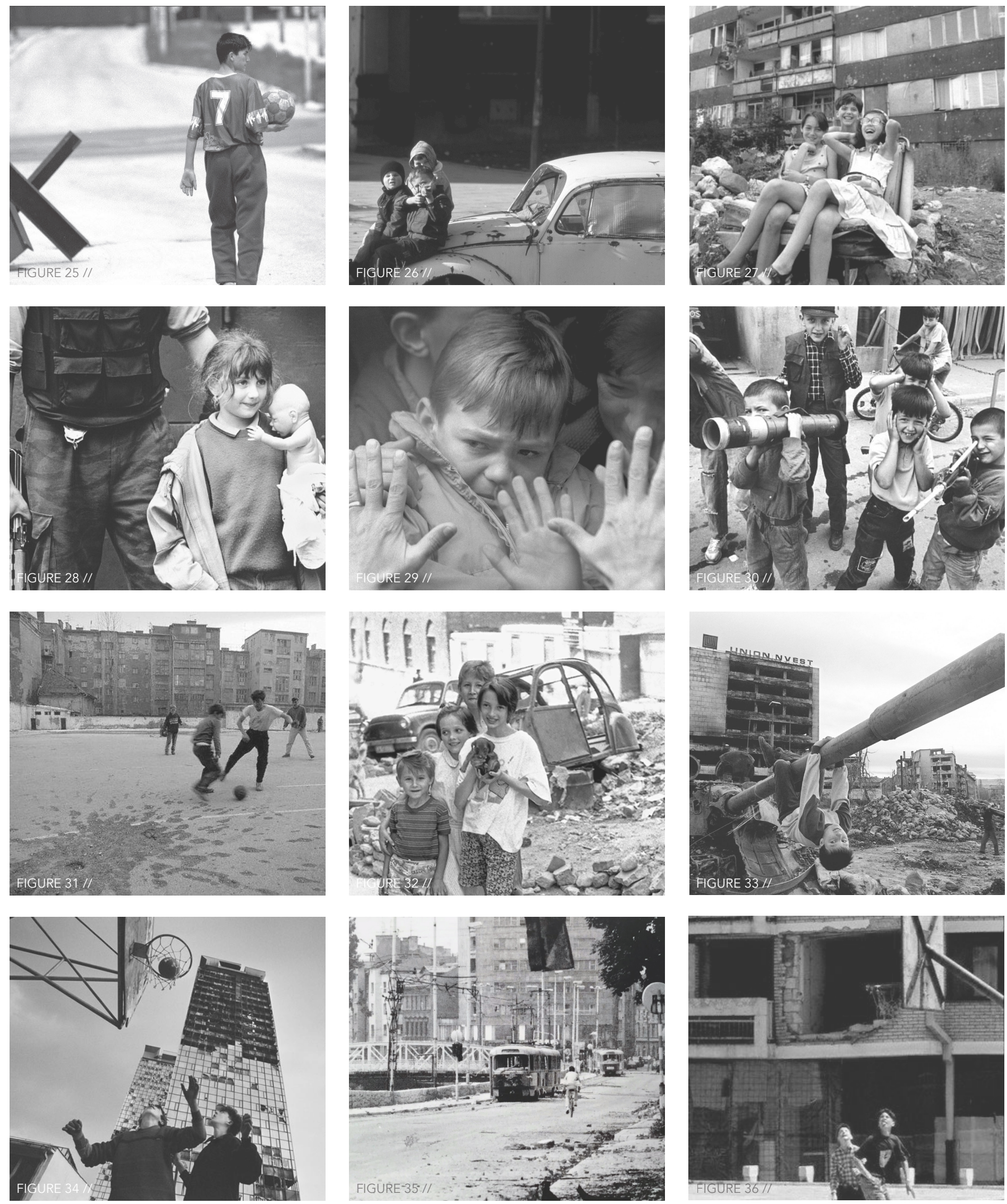
almost immediately. In February of 1994, the BSA attacked Markale Market, one of the six designated 'safe zones', for the first of what would be two separate attacks throughout the duration of the siege. The first instance, killing 68 civilians and wounding 144, was when the UN decided it was time to step in more forcefully.

As its strategy remained unchanged, despite escalating violence, the UN's credibility was diminishing further and NATO's involvement, an organization designed to fight war, if necessary, in order to defend peace, grew in scope. In July of 1995 when the BSA entered Srebrenica, a small mountain town in eastern Bosnia that was another designated 'safe zone', and ordered the genocide of more than 8,000 Muslim boys and men, NATO had reached a breaking point. 'Operation Deliberate Force' began, involving heavy bombing of the BSA until they were ready to negotiate. The second attack on Markale Market occurred just one month after Srebrenica, killing 38 civilians and wounding 90, to which NATO responded with even

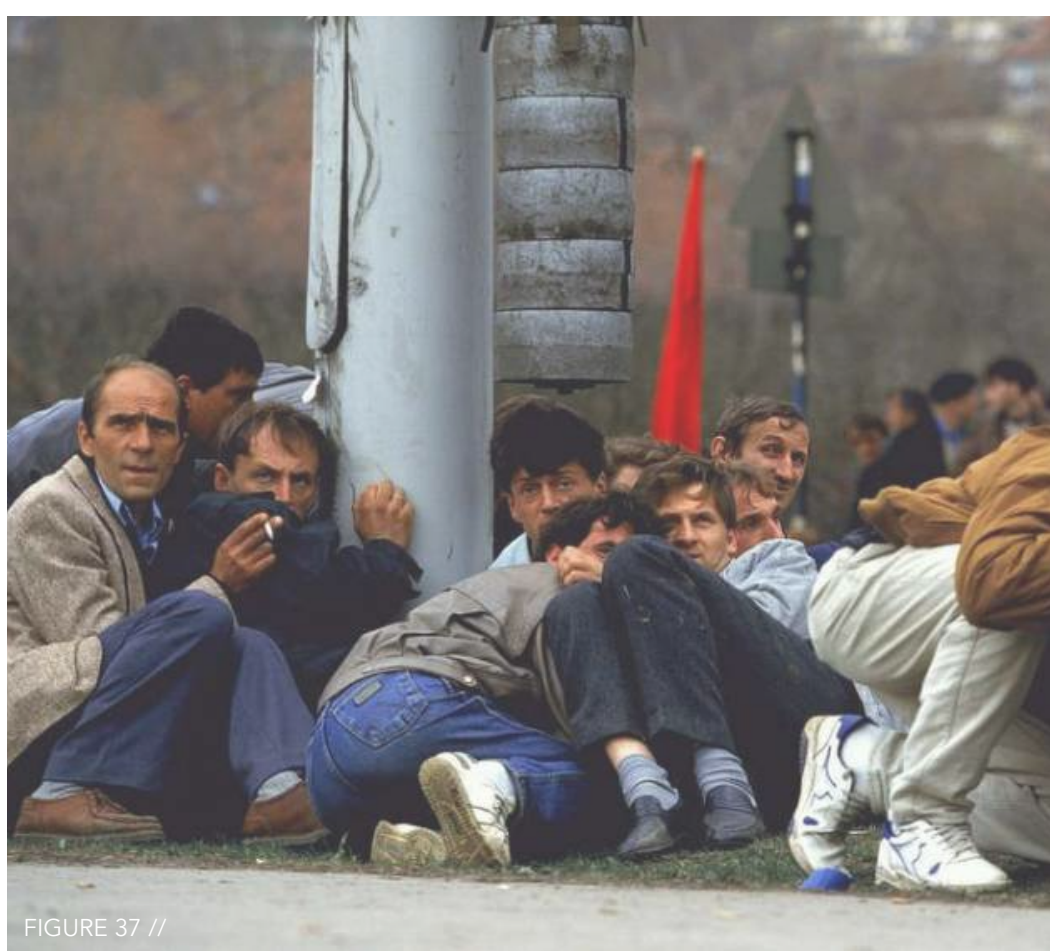




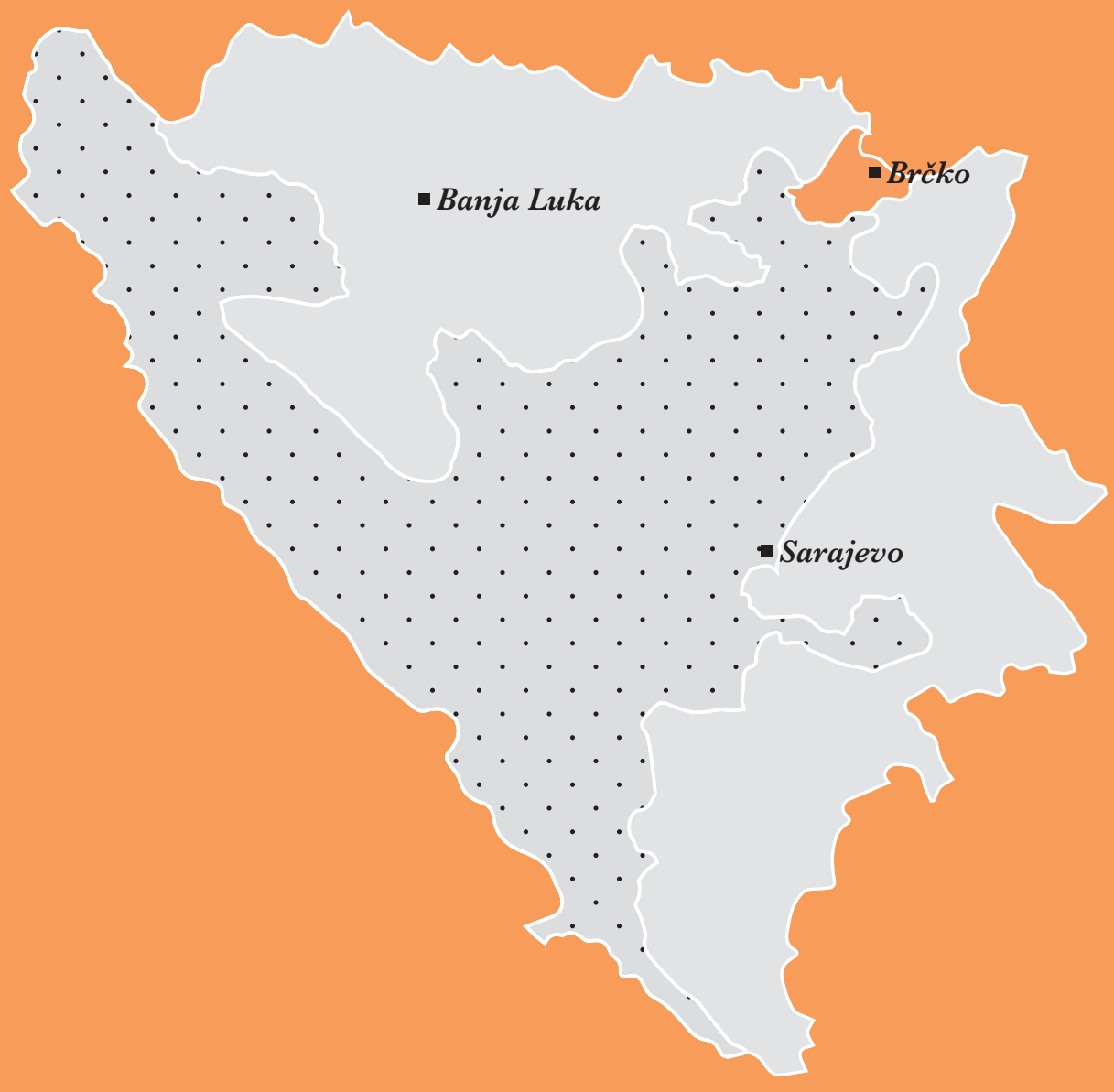

Federation of Bosnia \& Herzegovina

Capital: Sarajevo

Majority: Croat-Muslim

Regions: 10 cantons

$49 \%$

The Republic of Serbia (East Sarajevo)

Capital: Banja Luka

Majority: Orthodox-Serb

Regions: 5 districts

NEU

Brčko District of Bosnia \& Herzegovina

Territory: Neutral

Jurisdiction of the government of $\mathrm{BiH}$ 
more bombing before a ceasefire was reached in October of 1995. These attacks were meant to sow a landscape of fear, intentionally destroying the socio-cultural elements that are the essence of Sarajevo: its ethnic diversity, its vibrant urban life and its culture of communally gathering for arts, fairs, cinema and sporting events.

The war ended with the 1995 Dayton Peace Agreement, forming two separate entities within a unitary state: The Federation of Bosnia \& Herzegovina, possessing $51 \%$ of the country's territory, and the Republic of Serbia, possessing 49\%. Brčko, a small area of land between the two, remains neutral and belongs equally to both entities under the jurisdiction of the government of $\mathrm{BiH}$. To ensure that the treaty was being honoured, NATO sent 60,000 peacekeepers throughout BiH in December of 1995, and the Bosnian government officially declared an end to the siege of Sarajevo on February 29, 1996. The conclusion of the war marked a process of triple transition across the whole country, moving from war to peace, from market socialism to a free-market economy, and from socialist to democratic government. Today, the head of the country's presidency is operated under three members, with one representative each of the Bosnian, Croatian and Serbian people. Among the extent of terror inflicted upon the city, it couldn't possibly be called a war; "this was a horror that has no name."12 But despite it all and with minimal resources, Sarajevans had the strength and will to resist. They managed to maintain their dark sense of humour, to pursue some sort of activity besides survival, and fought to defend their city while preserving their dignity. Sarajevans were the ones who kept their city from falling apart. 
War can damage two different types of identity: a social identity belonging to people within a community, and a collective or group identity, considered to constitute a national heritage. When the war in $\mathrm{BiH}$ began, its pattern of intent was evidently systematic. "There was a clear escalation from simple territorial gain and the murderous expulsion of the local population to actual genocide and systematic cultural cleansing." 13 The erasure of collective memory and honoured history was accompanying the erasure of a people. In support of their goals of ethnic cleansing the BSA undertook a campaign of 'memoricide'; known as the destruction of memory by extermination of the past of its targeted people, with the sole purpose of destroying Sarajevo's cultural history. Throughout the first year of the siege repetitive acts of deliberate cultural destruction were carried out, and numerous public buildings that were symbolic to Sarajevans were the targets. The Olympic Museum was one of the first buildings hit, notably followed by Zetra Olympic Hall, the Post Office, the UNIS Twin Towers (Figure 38), the Parliament and government buildings, the Elektroprivreda Building (Figure 39), Vijećnica; the National and University Library (Figure 40), offices of the Sarajevo Daily Newspaper (Figure 41), the Holiday Inn and Dom Mladih at Skenderija. The pseudo-Moorish built Vijećnica, formerly Sarajevo City Hall, famously housed two million volumes of rare manuscripts and original documents archived in the greater part of the most important library in BiH. During the first few months of the siege, aggressive shellfire and combustible missiles deliberately thrown at Vijećnica caused the library to go up in flames. The library was a clear landmark and symbol of Sarajevo and every single page was irretrievably lost.

The targeting of Vijećnica had no strategic military value and the psychological wounds inflicted by such acts are much more difficult to grasp. 


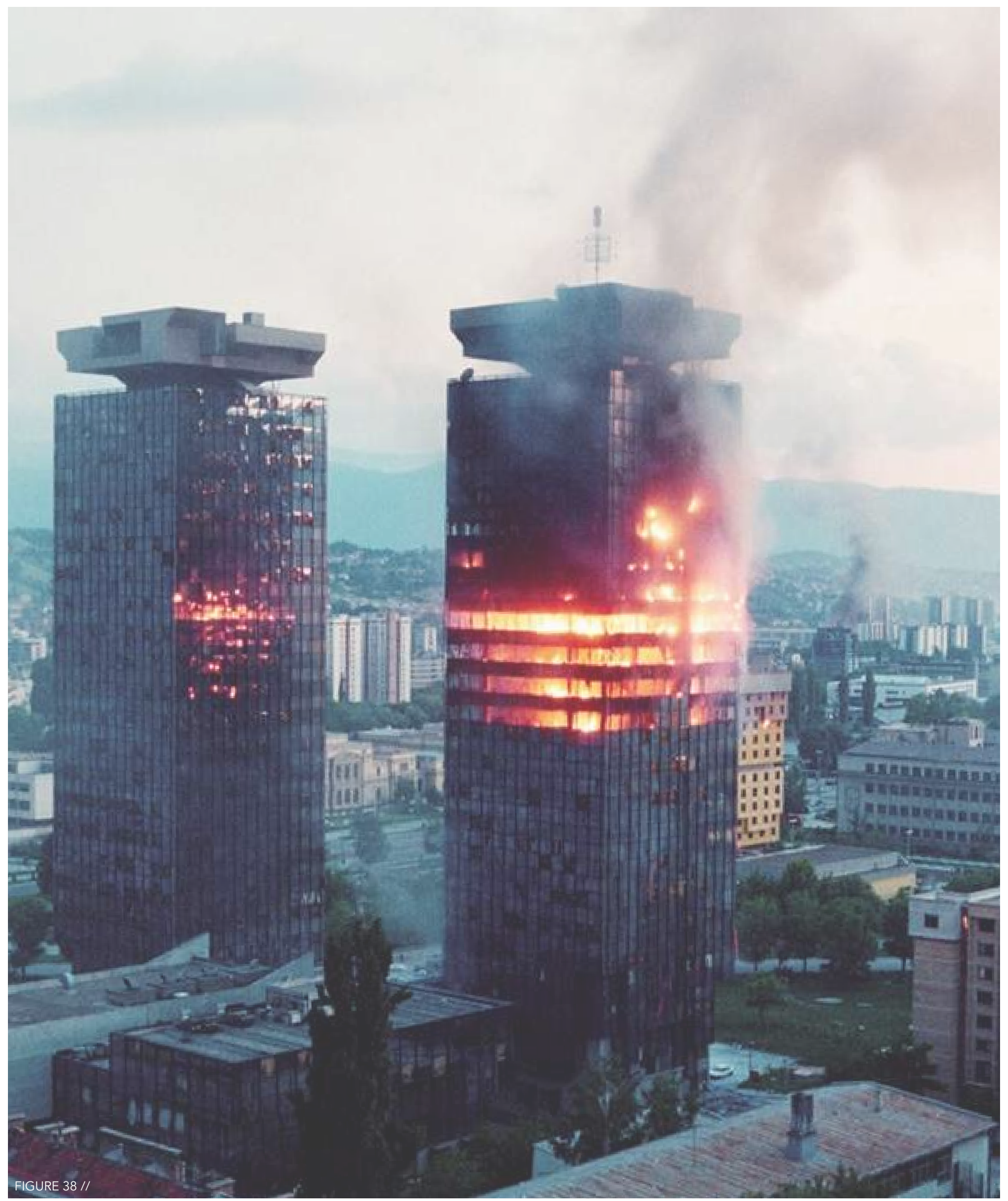




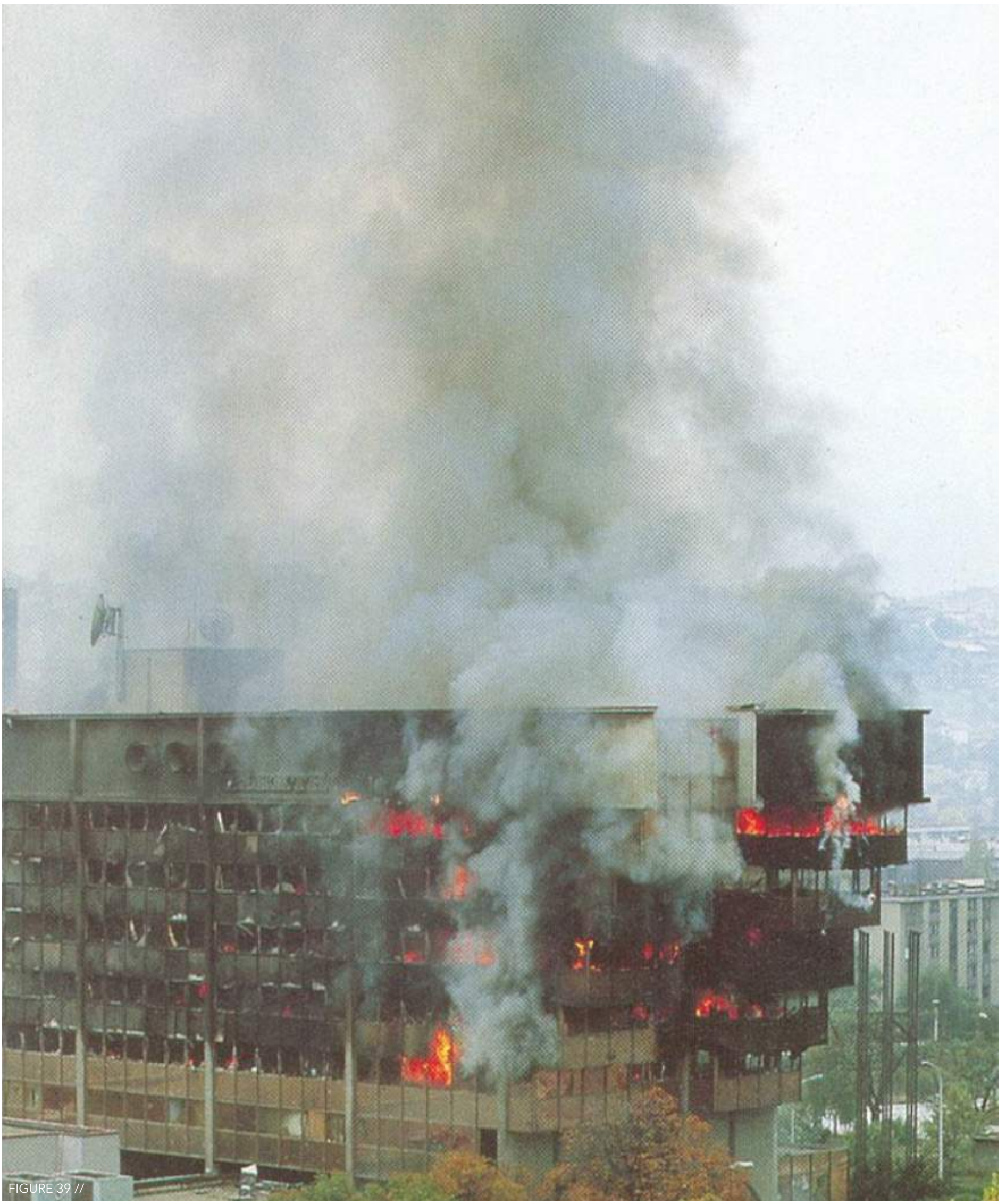




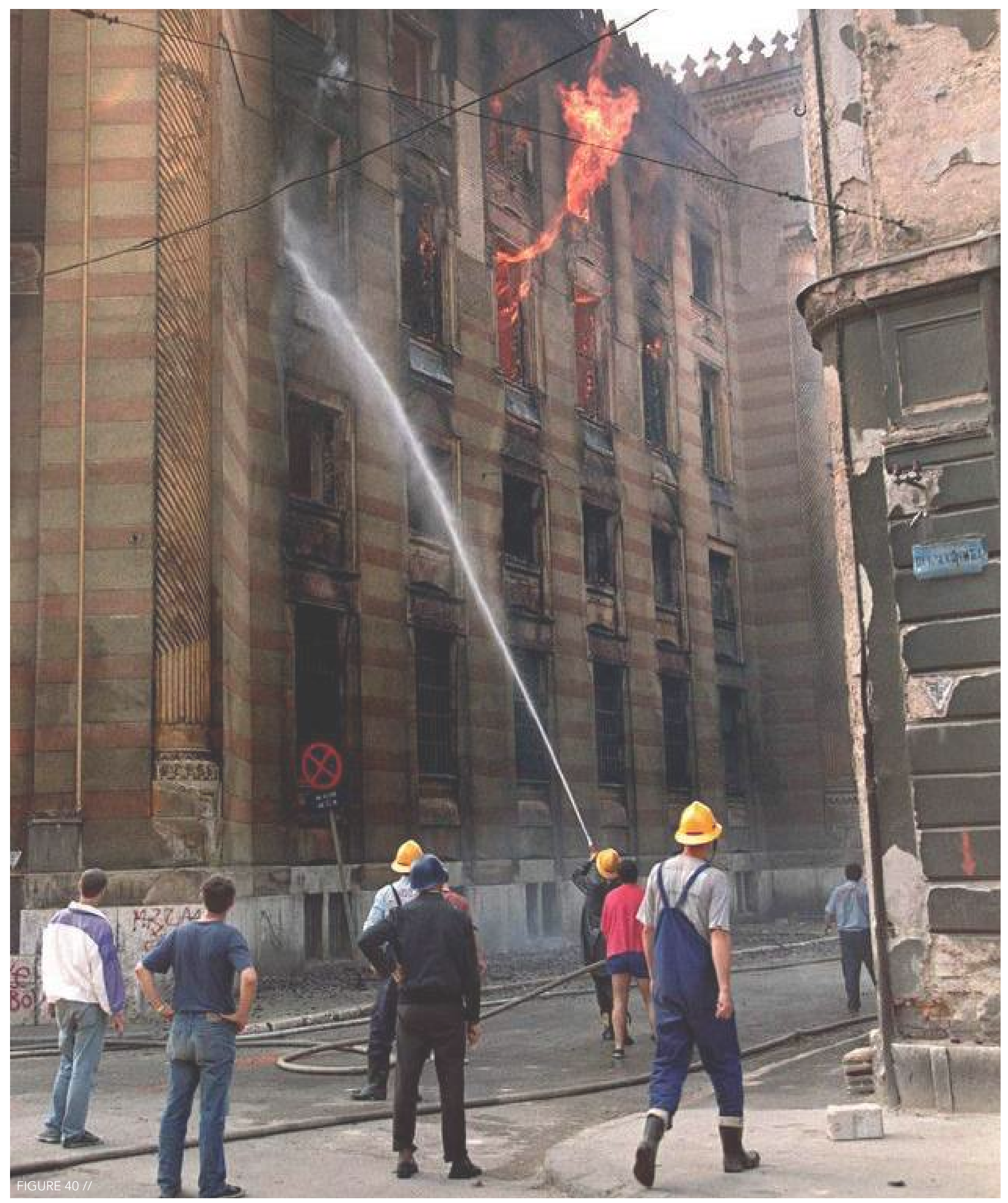




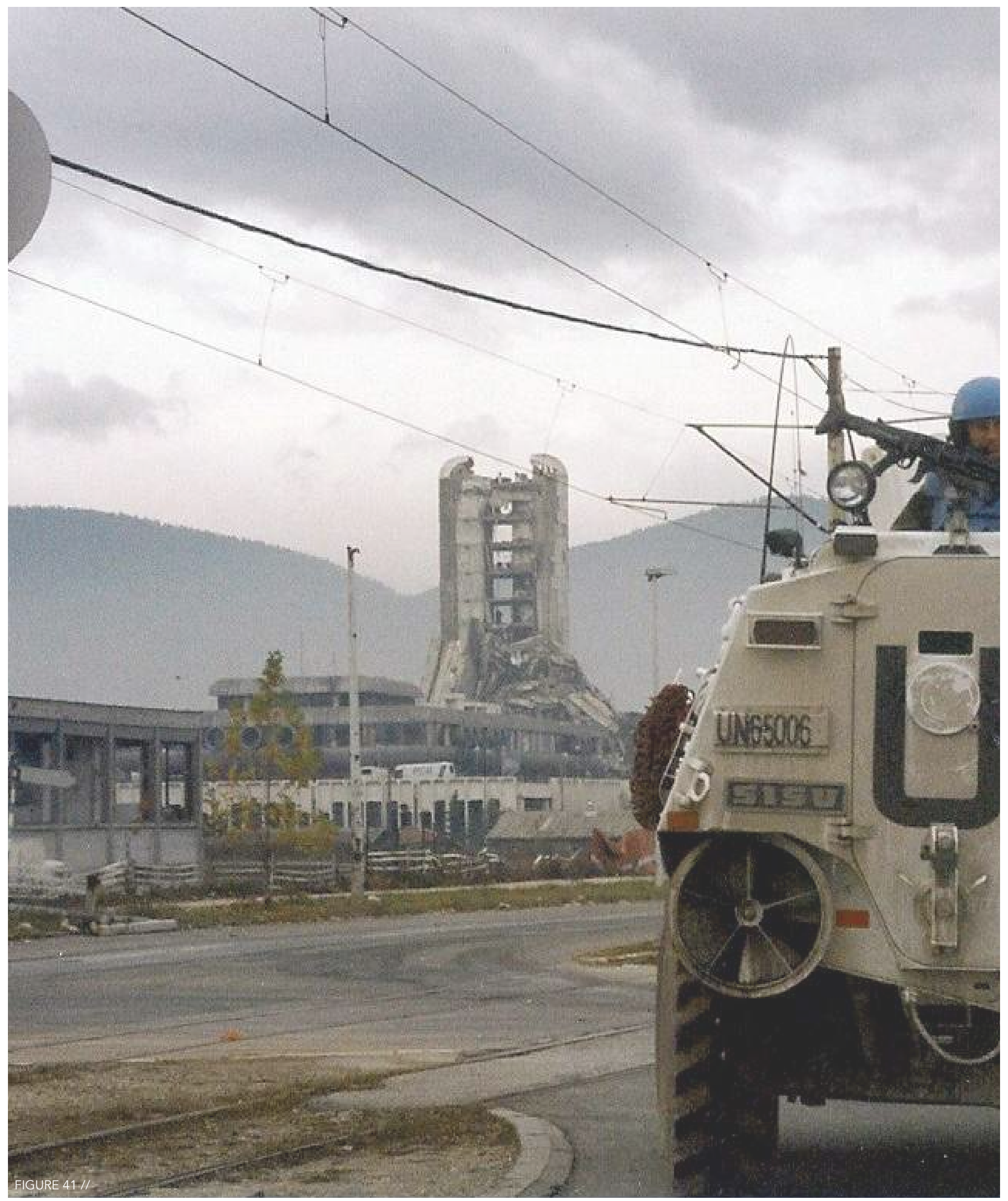


The collections were the very source of the Bosnian and Yugoslavian people's identities showing that past generations of ethnically mixed traditions once successfully shared a common life. The erasure of their remembrance was an attempt to create a society that can be influenced by nationalistic views. Sarajevans were deeply affected by the destruction and burning of their heritage, both literary and architectural, "representing the destruction of their collective identity." ${ }^{14}$ The bombing of Sarajevo's daily newspaper building was another special case in the besieged city. Oslobođenje, meaning 'Liberation', was established after World War II where it became symbolic to "the struggle against fascism, the fight for freedom, and the unification of the Yugoslavian people." ${ }^{15}$ After the $1000^{\text {th }}$ shell hit the building in August of 1992, its staff stopped counting. It seemed as though the BSA had an exceptional desire to destroy Oslobođenje because it reflected the national composition of Sarajevo's society. While a few Bosnian Serb journalists left the newspaper at the beginning of the war, its staff remained ethnically mixed and retained a strong defence of Bosnian-Herzegovinian pluralism. Once the building was knocked down, the editorial rooms and printing presses were moved to the basement beneath all the rubble. Oslobođenje did not miss a single day of publishing throughout the siege, defying that "Serbs, Muslims and Croats can work and live together in harmony."

The notion of 'urbicide', not unlike memoricide, is the purposeful attack on "the human and inert fabric of a city with the intent of destroying the civic values embodied within it." ${ }^{17}$ Destroying buildings and public spaces that served important cultural functions, with which Sarajevans could identify with, were disappearing; their history, culture and identity being erased with it. Vukovar, Mostar and Sarajevo, the three BiH cities that were cosmopolitan, pluralist, ethnically mixed and liberal, were the complete opposite ideology of racial purity that the BSA was striving for. The "comingling of mosques, Catholic and Orthodox churches in Sarajevo, is an embodiment in stone of everything the Serbs were fighting against."18 Urbicide, however, requires more than the physical attack on individual 
buildings of representative communities. It is the accumulation of buildings that foster the environment of shared spaces for interethnic mingling of a community. The mind-set is that the architectural conditions that promote "this heterogeneity have to be destroyed if an ethno-national or ideological homogeneity is to take its place."19

The BSA directly attacked spatial practices of everyday life and disrupted free-flowing space into places of immobility. This wasn't solely done through the destruction of built form, but rather through the addition of spatial boundaries within Sarajevo's urban fabric. Through the establishment of the siege line and the sniper's view-sheds, the city's places of mobility were transformed into barriers confining Sarajevans to ethnic enclaves. The Miljacka River, instead of acting as a connective spine running through the heart of the city, was "transformed into a strip of ethnic division as its bridges, which became exposed and dangerous, disconnected rather than connected people." ${ }^{\prime 20}$ Additionally, the destruction of public architecture indicating the mixing of cultures was three times higher than those linked to particular ethnicities. The fear of death at every turn intimidated the surviving Sarajevans and hindered the ethnic mixing of people, in turn changing the collective identity of Sarajevo as a society.

While a building can be located on any given site, it is the reservoirs of human content, the personal and common values of its memory accumulated over time that turns a building into a place. Place can also be used to describe the urban public spaces that the BSA systematically pursued with artillery attacks against the mixing of people. In destroying public spaces of gathering such as playgrounds, queues, and markets alongside symbolically important places, the tacit goal is to debilitate enemy morale, taking from the besieged people that which would cause the most pain. This was an ever-present tactic of the BSA in the creation of their varying topographies of terror inflicted upon Sarajevans, significantly altering the associated collective memories of each individual. To recognize why this is relevant, 
we must acknowledge two fundamental truths about humans. The first being, without memory we are nothing: if we don't remember the past, we have no structured life. The second, that we are social animals, linked to social memories: if we lived a life in isolation, we would not learn. ${ }^{21}$ Our whole identities are interconnected with memory and history, drawing on cultural and historical understandings of our societies. Our interactions with these built environments and the recollection of such experiences begin to distinguish and create the social identity of a place. From the perspective of the BSA, the numerous shellings of Olympic facilities were successful procedures, as the highly regarded collective memories belonging to an entire nation were being altered drastically. Zetra Hall, where ice hockey and speed skating took place was burned to the ground and its bleachers used as firewood for fuel. Koševo Stadium, where the opening ceremonies were broadcasted for the entire world to see was turned into a cemetery for Sarajevans, as there was nowhere else to bury the dead. Mount Trebević, where the luge and bobsleigh events competed, was repurposed as a Serb military post where sniping and shelling would rain into the city below; sometimes only seconds apart, for the entire day. Similarly, the shelling of main pedestrian zones such as the Markale Market, the busiest place of urban life during the siege, indicates that the BSA was simply looking for the largest number of casualties.

The BSA's threats were effective "by making a psychological impact on their memories," ${ }^{22}$ and conveying the message that any future gathering and mixing of Sarajevans, regardless of ethnicity, was under attack, as was all civil society. The violence that the BSA was investing onto shared urban spaces was aimed at killing all hope for a shared united state, where the mixing of ethnicities would continue in celebration. An individual doesn't need to personally experience an event in order to possess the collective memory of it, but "it must be of such importance that it is thought of in memory rather than in historical terms. ${ }^{\prime 23}$ In this way, the preservation of our collective and social knowledge can be passed through members of a community, ensuring 


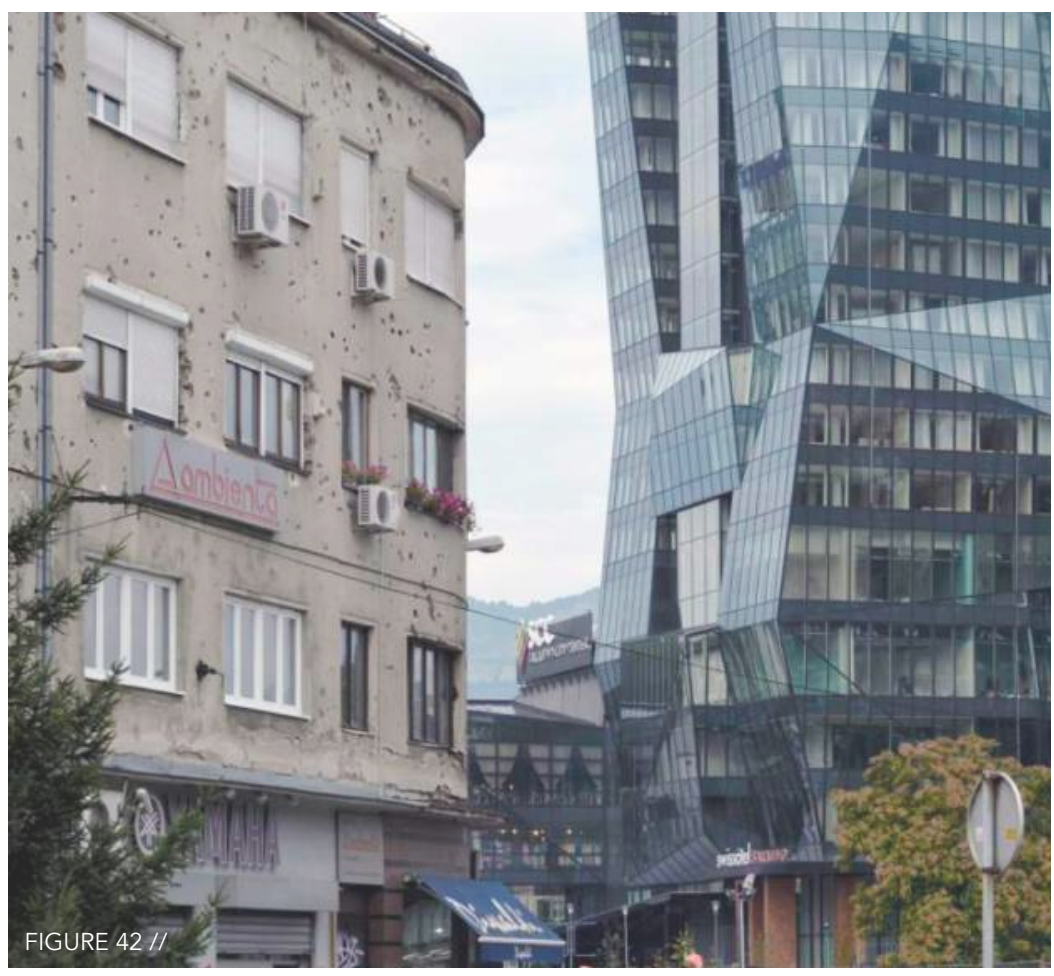

its continuity and sharing a sense of unity. Through the selective memory of memorials, statues and the naming of streets and squares, to the imposed memory of visible scars on built environment and abandoned buildings representing inheritances of the war, an acknowledgement of the siege is deeply embedded into the cityscape.

An effort to embody and preserve the multi-ethnic Sarajevo becomes a form of acceptance for what has been suffered, but more importantly, what has survived. With its proximity to the front line and for what it represents as a multicultural centre, Skenderija was badly damaged at the beginning of the war. When Dom Mladih entirely went up in flames in the first few months of the siege, the UN decided to repurpose the whole complex as their humanitarian aid base camp. Surrounding the site there is a multitude of selective and imposed memories. This thesis intends to merge both within each Sarajevan's collective memory, repairing the wounds as we continue to move towards diversity, and not away from it. 


\section{6}

\section{To go outside is to}

accept the possibility you will be killed.

On the other hand, the same can be said of staying inside.

// Steven Galloway, The Cellist of Sarajevo, 35 
Throughout Sarajevo architecture and urban spaces were adapted in order to resist and persist in the new reality of urban wartime circumstances, which were forced upon Sarajevans and promoted into a permanent condition. In order to survive "residents had to change their spatial thinking about the city and their everyday urban habits." 24 This destruction rarely happened suddenly and totally, but rather gradually and continuously, allowing space for Sarajevans to come to terms with these disruptions and negotiate their new normalcy. When the simple act of crossing the street became possible only at a run, Sarajevans developed strategies to limit their chances of being hit. By counting time between two shots, they could approximate how many seconds they had in order to make it to the other side. When food became a scarcity, plants on balconies and windowsills, where possible, were replaced with lettuce, onions, parsley, carrots, beets, tomatoes, and all sorts of other things, becoming vegetable gardens. Survival techniques, such as constructing trollies to bring water containers home from the Sarajevo Brewery (Figures 44-47), the organized art exhibitions and theatre performances, or the creation of makeshift stoves out of tin cans and fire (Figure 48), were all forms of what was being referred to as the 'imitation of life.' These attempts to preserve normal forms of life through activities that were highly abnormal were a creative acceptance of one's conditions as a form of resistance in itself. ${ }^{25}$

An architectural adaptation of everyday life within these urban rhythms resulted in the development of a typology of physical and visual barriers that were intended to interfere with the snipers' view-sheds. 'Soft barriers' were used in areas of denser morphology between built forms, as it was easier to adapt to resistance by stretching large canvas, curtains or cloth and attaching them from one building façade to another (Figure 50). Despite 

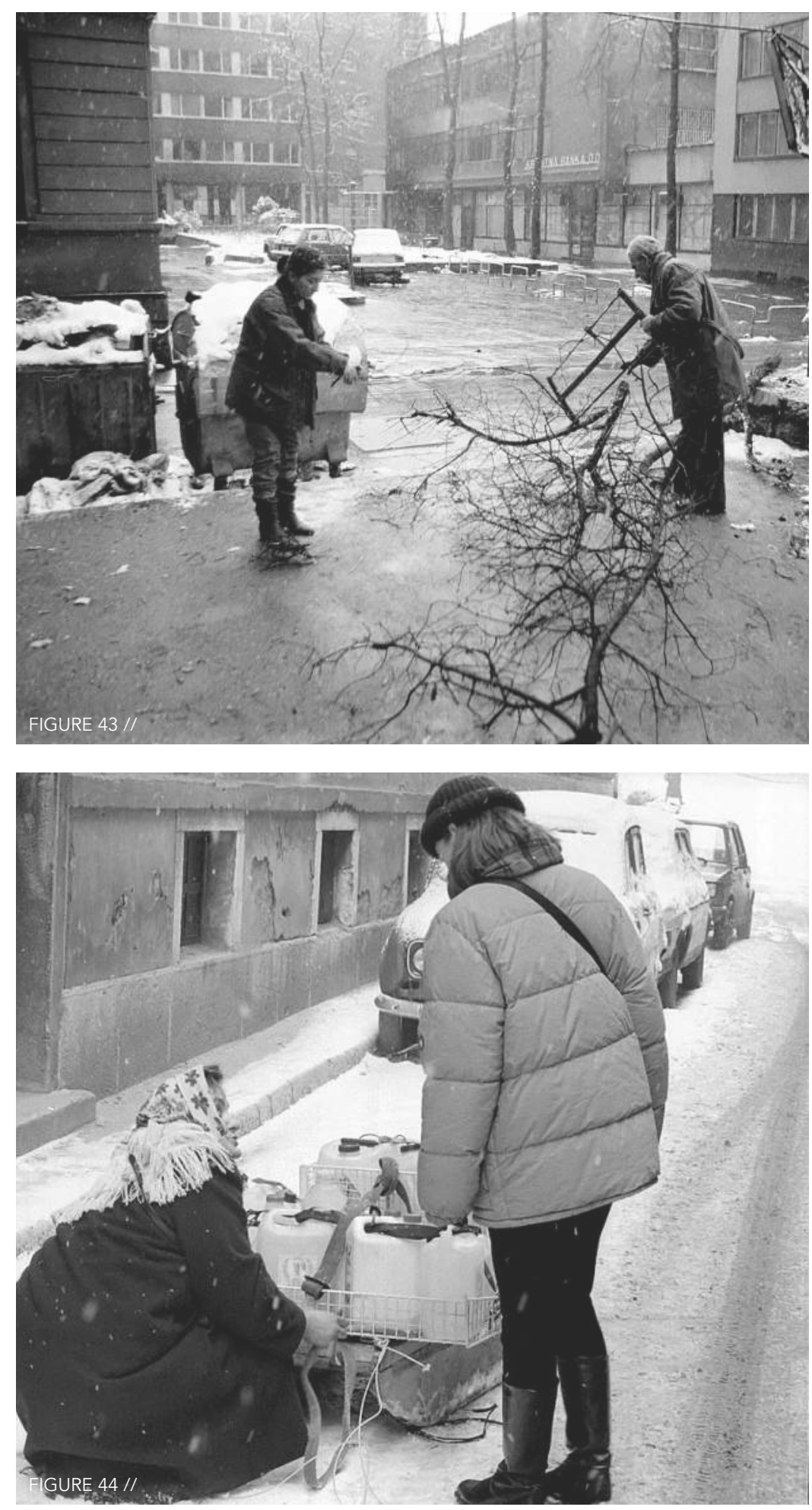

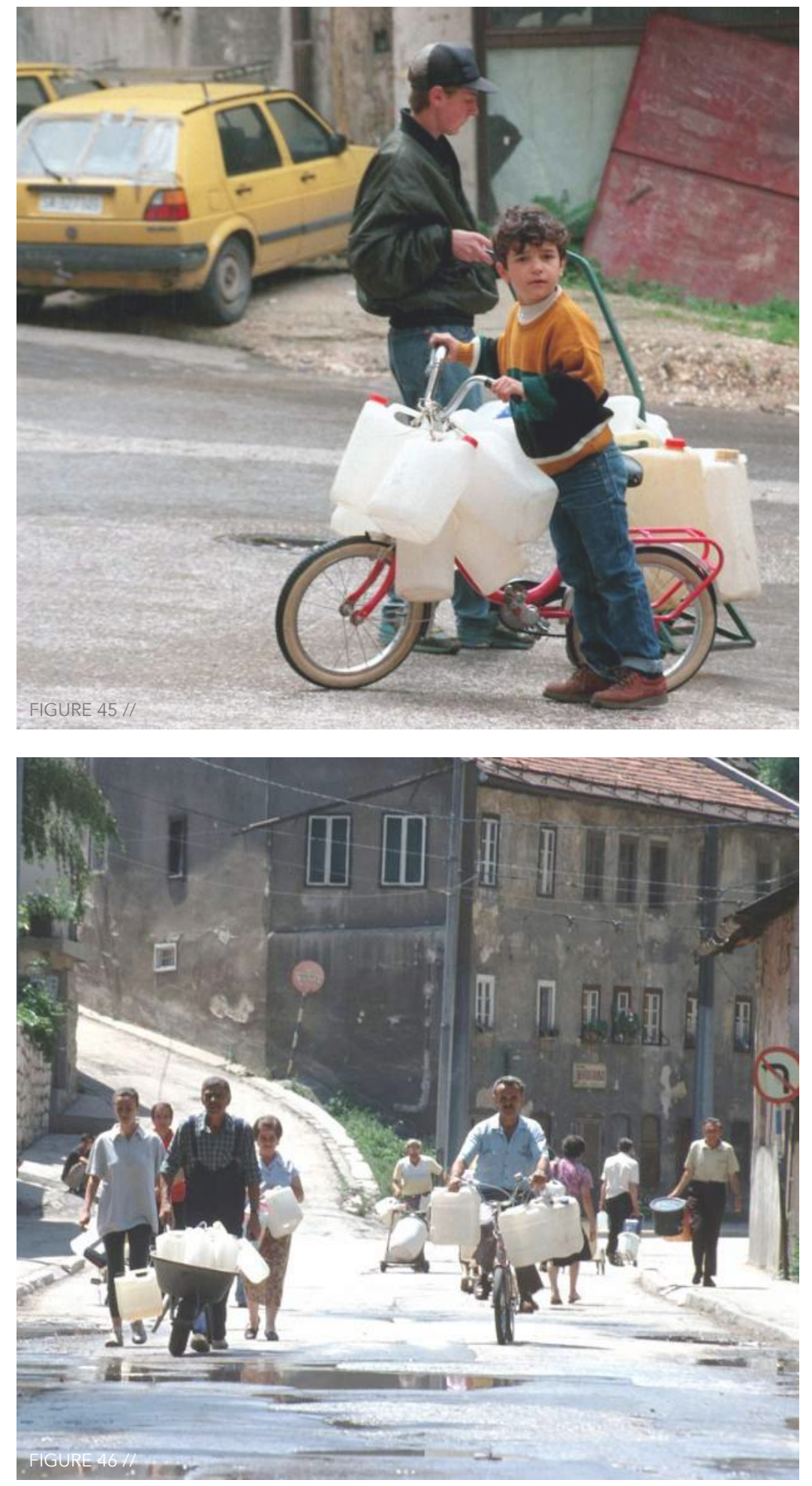

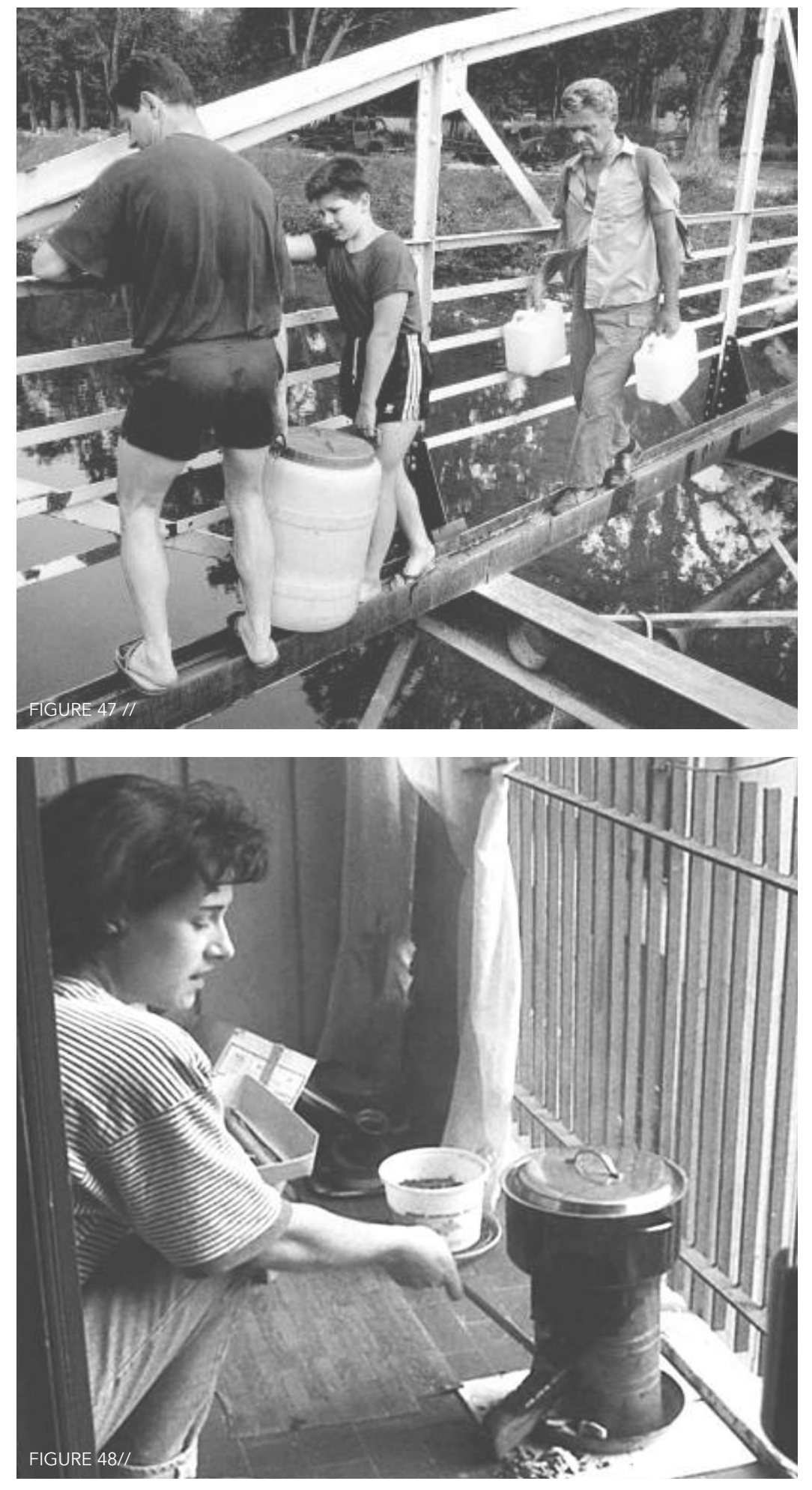


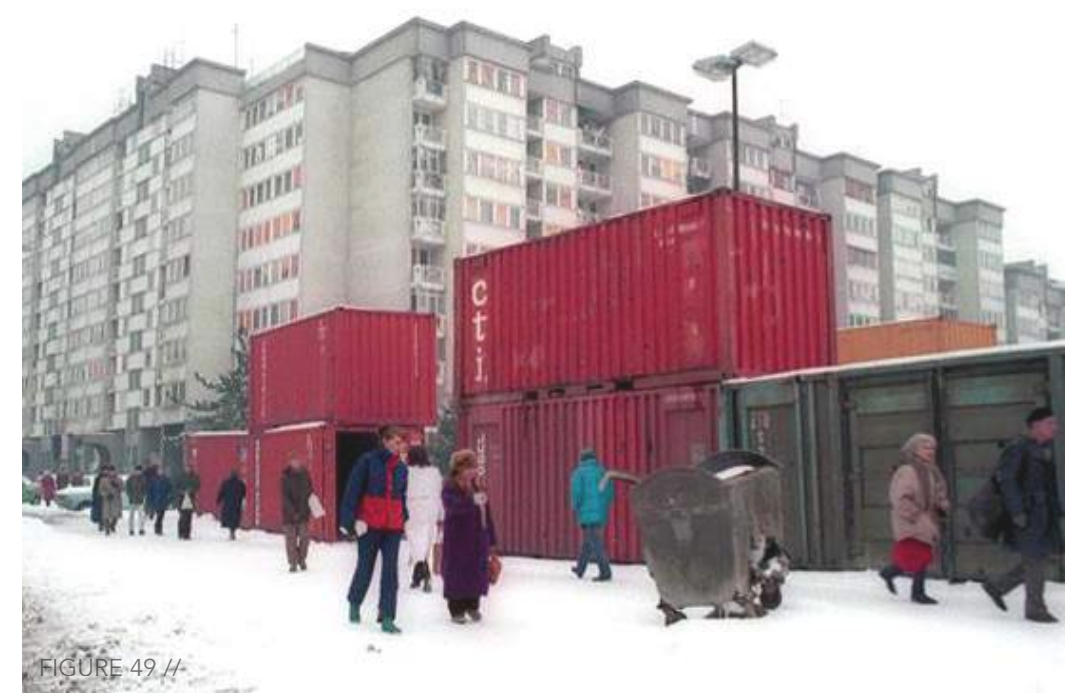

blocking the snipers' views, these were classified as 'soft barriers' as they were not bulletproof - snipers could still shoot at random and kill people passing behind them. In areas of lesser density, 'hard barriers' were made possible with large pieces of cement sheeting (Figure 51), rows of sandbags (Figure 52), shipping containers and destroyed cars and trams piled atop each other (Figure 53). In the socialist town of the city there was a succession of shipping containers lined up side by side, forming a long, protected strip of urban space to the north of Sniper Alley; this became known as 'Put Života', which means 'Road of Salvation' (Figure 49). The boundaries installed paradoxically enabled pathways and flows of movement, reconnecting the city. This lifeline provided an area of perceived safety where Sarajevans "reclaimed their right to move and gain access to places of social encounter and mixing." ${ }^{26}$

Artistically, the need to resist the war resulted in an explosion of cultural life. The desire for pre-war routines and the aspiration to feel a connection to those around you beyond the limits of the siege, initiated an amazingly active life in Sarajevo. The moment power was temporarily restored, hair salons would fill with women getting their hair done; not because they were stupid to risk their lives for mundane things, but because the feeling that 

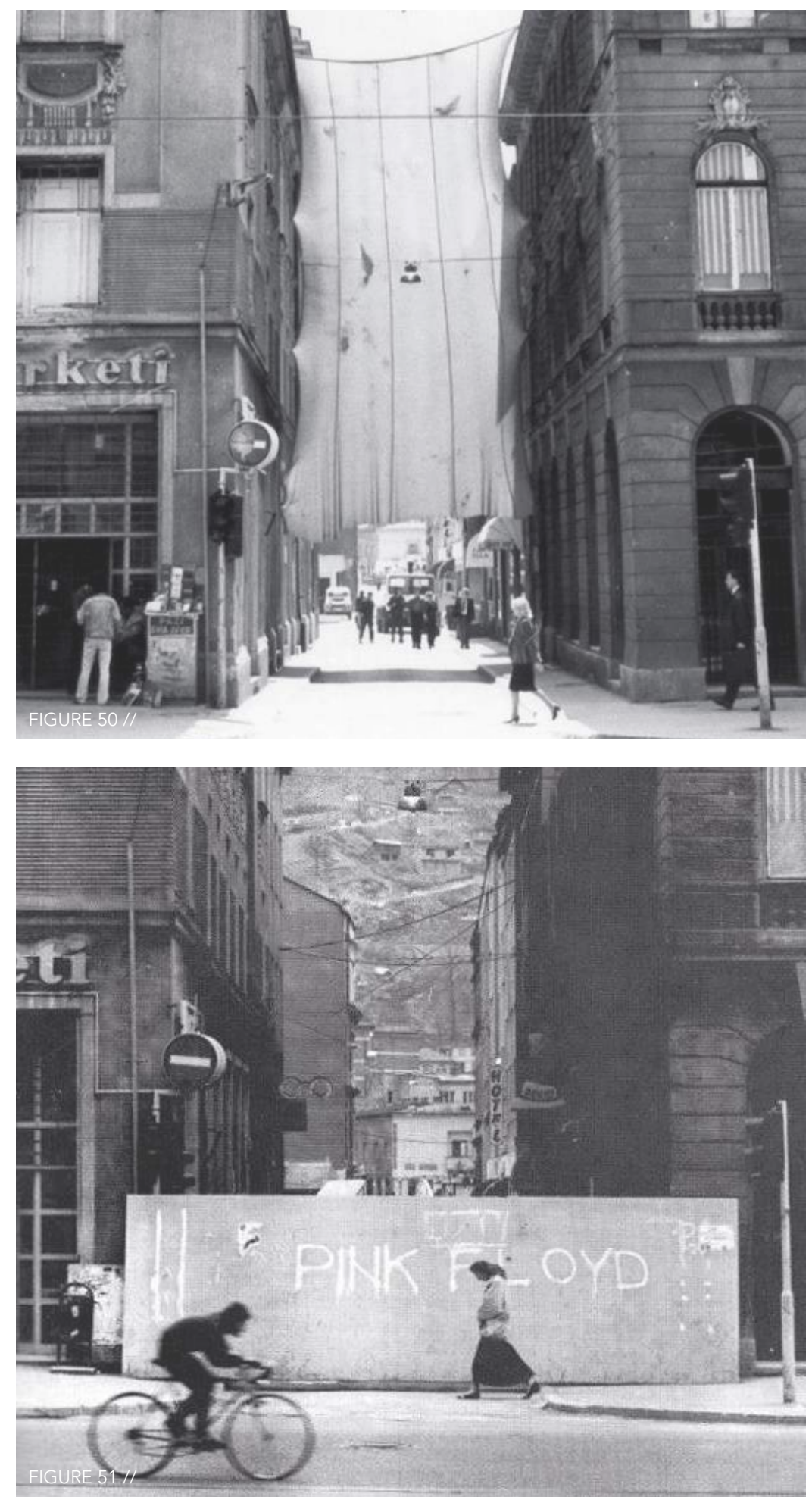

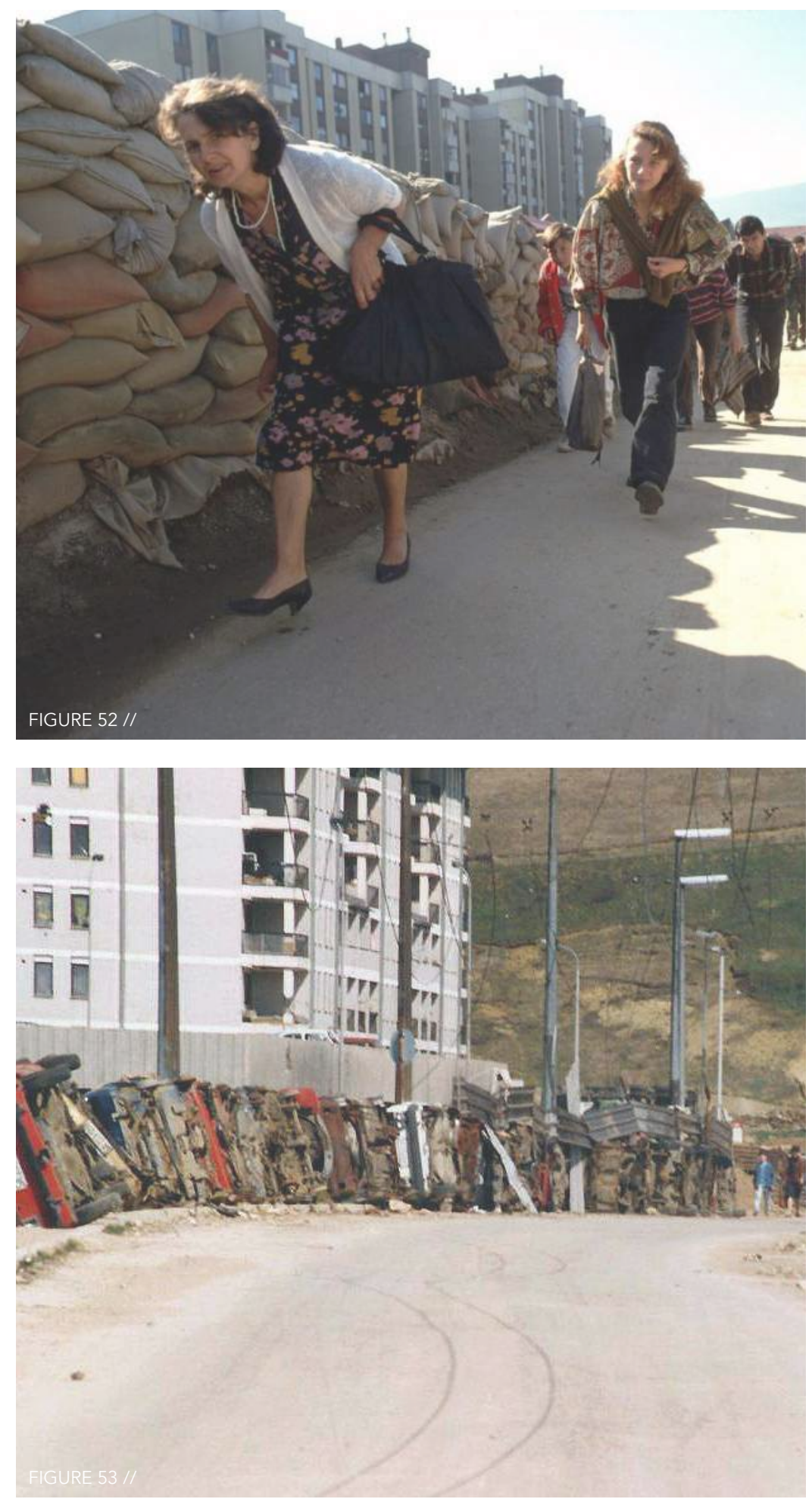

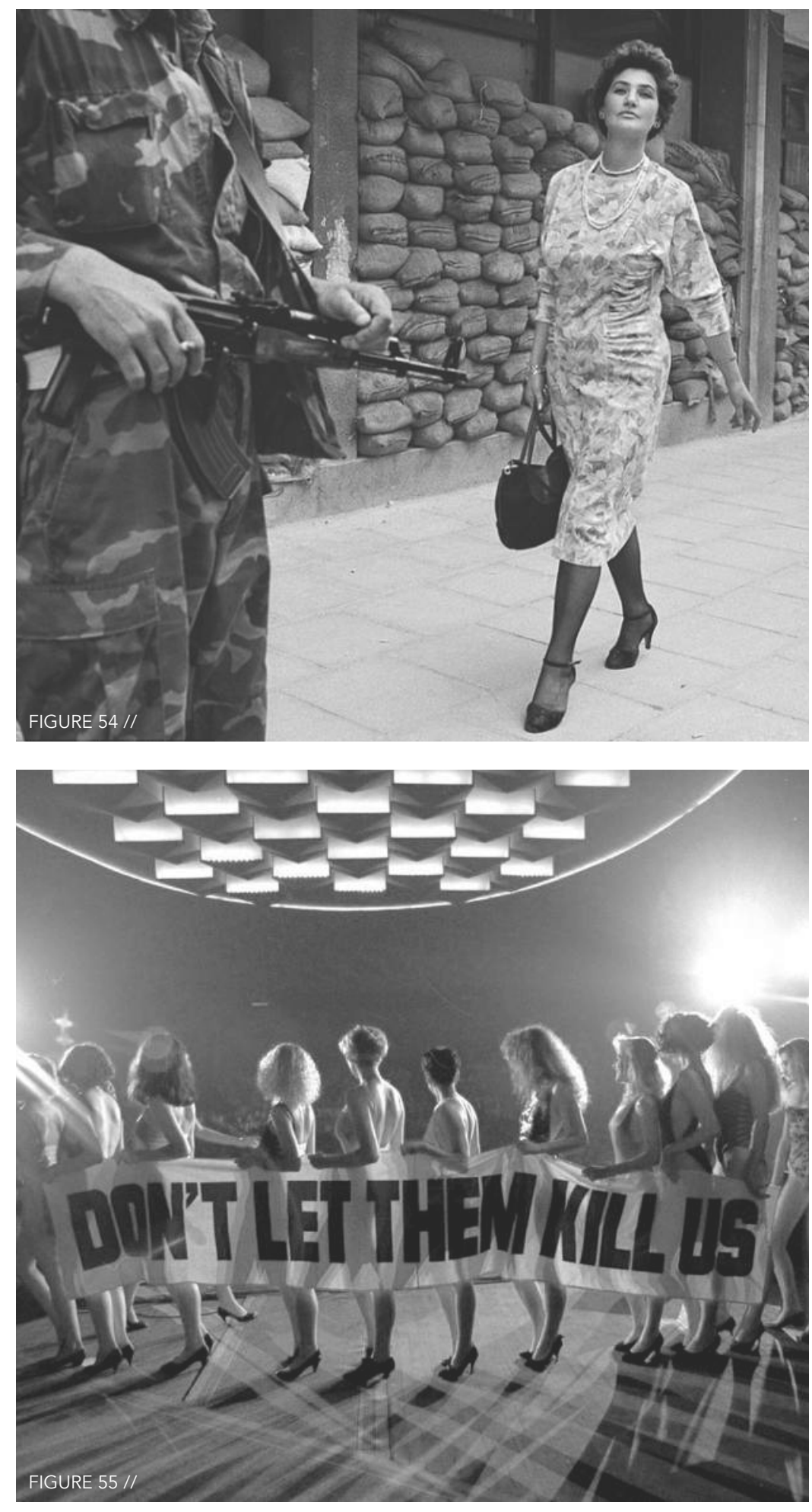


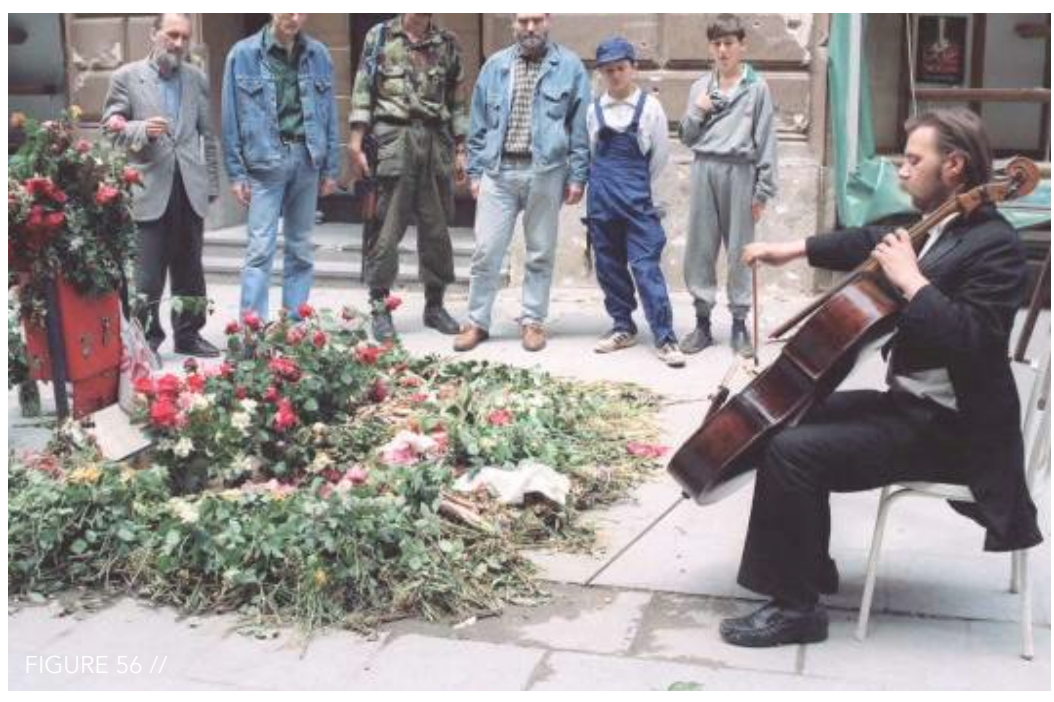

you're human can fade pretty fast. Little things like toothpaste, soap or shampoo were morale-builders like nothing else; there's not much point in fighting if you have to lose your humanity in order to do so. Comparably, many couldn't understand why Vedran Smailović, a local musician, was risking his life to play his cello in public following the shelling of civilians on Ferhadija Street (Figure 56). This was the first massacre of the siege, killing 3 and injuring 20 while they waited in line for bread. Prompting the 'cellist of Sarajevo', he played his cello in the street, one day at a time for each victim, showing resistance through art and music. As the only way to stop things from getting worse was to continue doing the things that you already knew how to do, art and theatre boomed in popularity. This provided an outlet for citizens to express and share the common everyday problems and traumas that were being experienced.

Despite the horrors happening around them, nothing manifested the strength of a human heart more than those who went on with their lives by attending organized concerts, putting on plays and even holding beauty contests. New spaces of urban life emerged by adapting the interiors of buildings into wartime areas of social interaction through the culture of exhibitions, theatre, film and music. Miss Besieged Sarajevo was held in 
the basement of the Holiday Inn during the summer of 1993, where the infamous banner read "Don't Let Them Kill Us" (Figure 55). Series of open spaces, basements of public buildings, and underground shelters were being used for organized movie screenings, and it was the high level of attendance that resulted in the establishment of the Sarajevo Film Festival in October of $1993 .{ }^{27}$ Although entrance fees were either free or the cost of a few cigarettes, the possibility of being killed on your way there was ever-present. Regardless of this possibility, every culturally adapted wartime space was full whenever a performance took place, and every performance was a victory of civilian life over war.

During the war there was "empirical proof that art and culture were as important as water and food." ${ }^{\prime 28}$ Once the performances began, no one in the audience made a sound, and during those few hours, Sarajevo was part of the civilized world. It was unexpected to see the city's cultural life this surprisingly vibrant. Nonetheless to prevent the misconception that Sarajevans engaged in the production and consumption of art daily, "we must note that the significance of these artistic events lay mostly in the fact that they were happening at all and that it was possible once in a while to attend them.. ${ }^{29}$ In order to preserve a sense of normality, one must preserve culture, and Sarajevo showed its spiritual integrity, strength, and resistance by its unbreakable spirit. With this persistence and ingenuity, Sarajevans continued to live and breathe without electricity, heat, food, or water, and it is this same persistence and ingenuity that gives the city its air of buoyant survivalism today. ${ }^{30}$ By the integration of their daily spatial routines, urban habits, and resilient creative minds, this thesis incorporates the cultural significance of film, together with the accessibility of places that promote mixing of ethnicities and building community. 
This is a city where you can travel through five centuries of history in less than half an hour; from an ancient tombstone, to the Holiday Inn, to the 20th-century towers, the distance is a couple hundred meters - and five hundred years. 







\section{THE DIVERSE CITY}

\section{// THE OTTOMAN EMPIRE}

The first significant period of history in BiH belongs to the Ottoman Empire, with the conquest of a citadel known as Vrh-Bosna, founded in 1263. It fell to the Turks in the 1450s and was renamed Bosna-Saraj. The town established an important Turkish military and commercial centre, ceasing to be just a border city and therefore experienced a period of steady progress. Several towns began developing along the rivers, creating crossroads of routes that became centres for trade. The name Sarajevo was later derived from 'saraj' of Turkish origin, meaning castle - in some ancient documents, Sarajevo is even mentioned as 'the City of Good Deeds.'

In the course of these four centuries of Turkish domination, the Ottoman culture stamped a deep impression on the country and its architectural development. Characteristically, it is simple, precise, and defined at the human scale. Apart from carved doors and red-tiled roofs being an integral part of each home, the unwritten rules demanded respect to the right of passage to a house, the right to a view, and the right to privacy. Beyond this, Sarajevo's social system and its characteristic representational spaces were expressed through spaces of worship, as belief was an important part of the daily routine. In order for practice to ensue, each newly appointed ruler considered it his duty to erect a new mosque, allowing the town to grow at an exponential rate. These religious buildings were not only thought of to serve spiritually, but were intended to serve culturally, educationally and socially, creating gathering spaces capable of accommodating collective or public activities.

Life in the Ottoman city was divided into two sections: the bazaar (Figures 59-60), representing the commercial quarter, and the mahalas (Figure 61), representing the residential quarters. Anciently, the mahalas were centred 

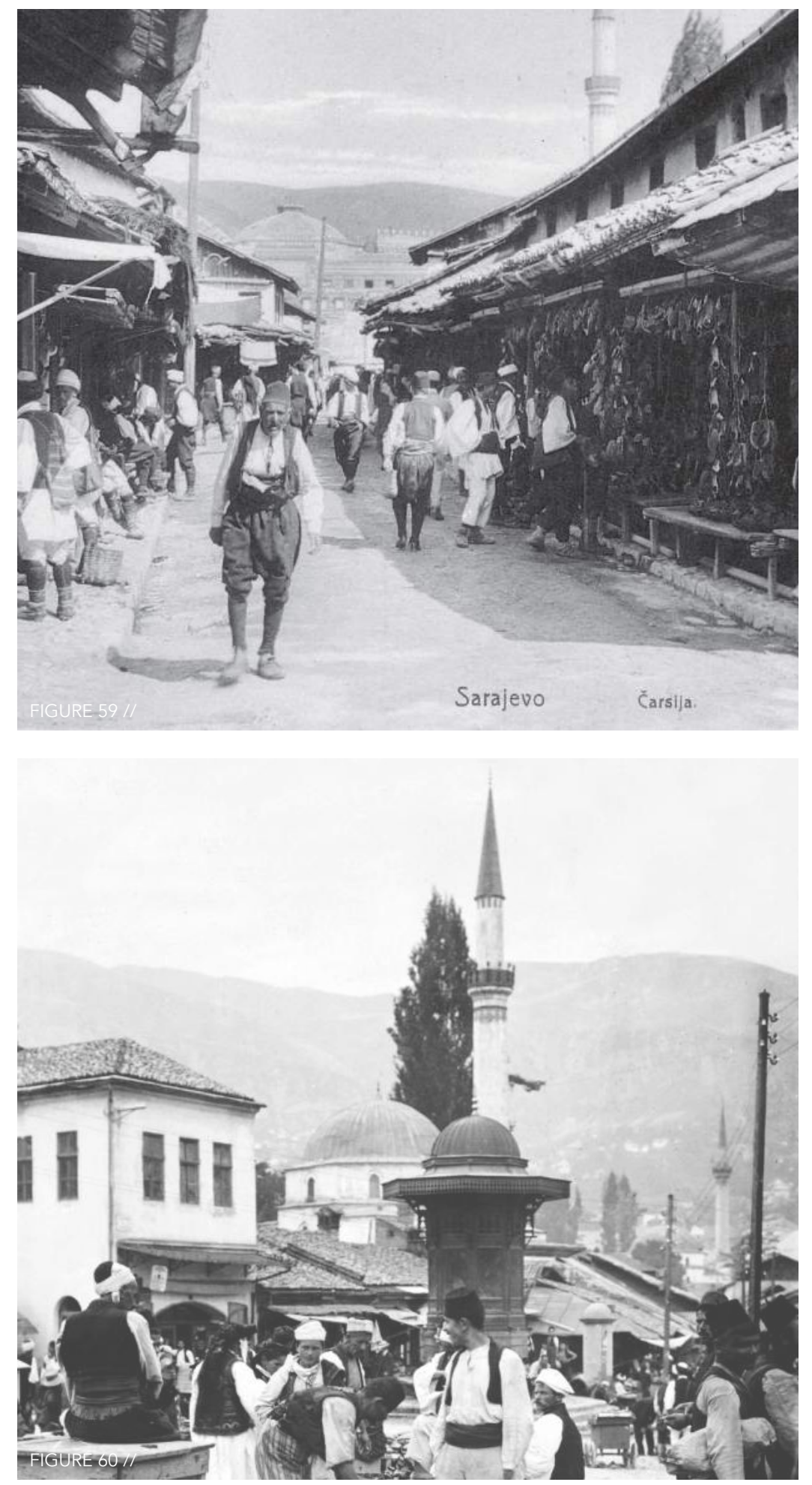

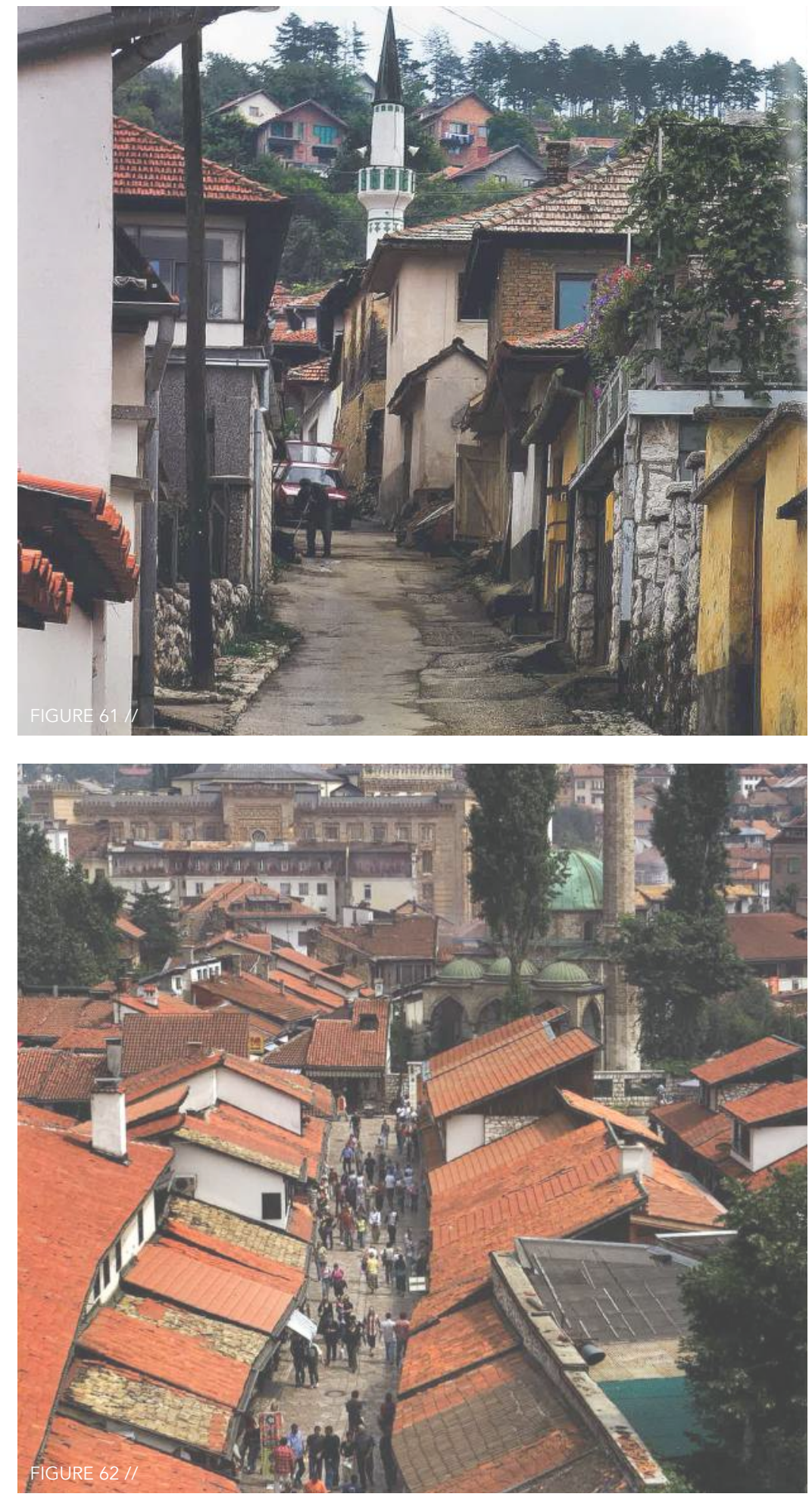


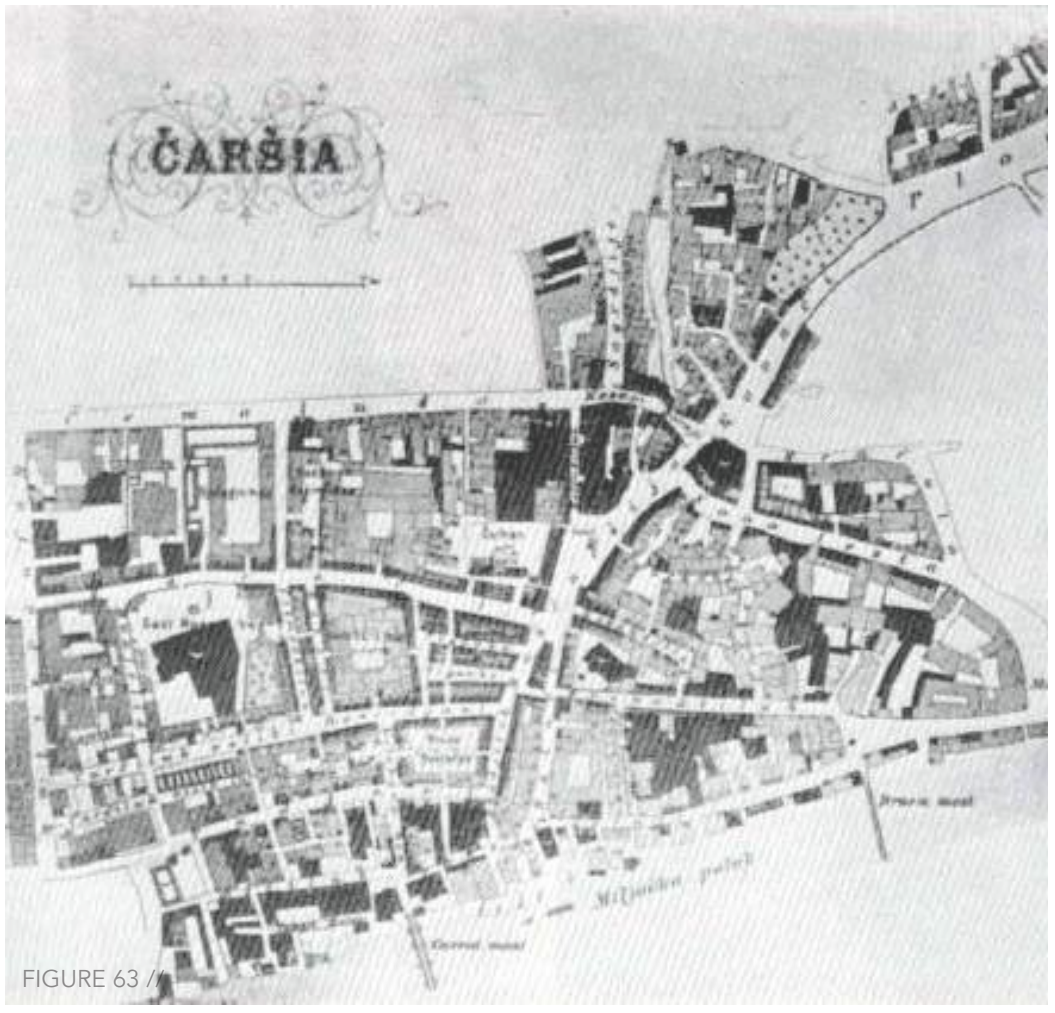

around a mosque and when there was no more room to expand a new mosque would be built elsewhere. This would initiate the development of another mahala, as "mosques and their minarets were the fundamental reference points for each neighbourhood."' Central to all of Sarajevo at the time was Baščaršija, the bazaar. The three main aspects of Baščaršija as a complex were crafts, commerce and catering. The shops of a particular association were grouped together in neighbouring streets, separating the sections of the bazaar per trade. For example, the coppersmiths (kazandžije) formed a bazaar in the complex known as the kazandžiluk. Today the coppersmiths' street and the goldsmiths' street are the two completely preserved 'čaršijas'. With regard to cuisine, for several centuries Baščaršija has been recognized for its notably modest, homey shops that serve cheap, quick and incredible food. Again organized by type, the cevabdžinica specializes in grilled meat, the buregdžinica prepares savoury pastries, and the aščinica is known for their cooked meals. 
Baščaršija in today's Sarajevo is an unusually attractive revitalized environment with strong historic features of narrow streets (Figure 62), mosques and drinking fountains, workshops with the continued devotion to old crafts, shops, and cafes lined side by side to one another. It is an area of Sarajevo where life bustles with the dynamism of an Islamic bazaar. Drawn from Sarajevo's first layer of life, this thesis will combine narrow passageways, café culture, and spatial configurations with varying degrees of privacy, offering the intimate characteristics of a bazaar. 
After four centuries of Ottoman control, BiH underwent another period of foreign occupation and interweaving: the Austro-Hungarian Empire. Following the end of the Russo-Turkish war in 1878, the Treaty of Berlin was aimed at distributing the territories of the Ottoman Empire and the four Balkan states of Greece, Serbia, Romania and Montenegro. The Congress of Berlin, where representatives of the six great powers of the time - Russia, Great Britain, France, Austria-Hungary, Italy and Germany - awarded Sarajevo and the rest of $\mathrm{BiH}$ to Austria-Hungary, where it remained until its 1918 incorporation into the Kingdom of Yugoslavia.

The direct encounter of eastern and western principles in Sarajevo was equally a time of growth and enrichment through contrasting dynamics and coexistence amongst two polarities. During its forty-year rule, the new government of $\mathrm{BiH}$ restructured Sarajevo according to the present day plans of Central European cities, reshaping its development to the west. While preserving the Islamic face of the city, the new administration made significant advancements of European ideals within its new territory. Its pragmatic approach, intensive building, technological developments, and cultural influences allowed the monarchy to draw Sarajevo and BiH into the realm of western thought and culture. Various public and administration buildings, residential blocks, churches, museums and theatres emerged in diverse architectural expressions of neo-Classicism, neo-Renaissance, neoGothicism, and pseudo-Moorish styles, forming Sarajevo's new Marijin Dvor district (Figures 64-67). Early on, the Austro-Hungarian administration founded the Zemaljski Muzej [National Museum], which was the parent institution for all cultural, educational, and scientific institutions in $\mathrm{BiH}$ to follow. In 1885, Sarajevo was the first European city to have an electric tram, serving as a test line for Vienna. It operated with horses for the first ten 

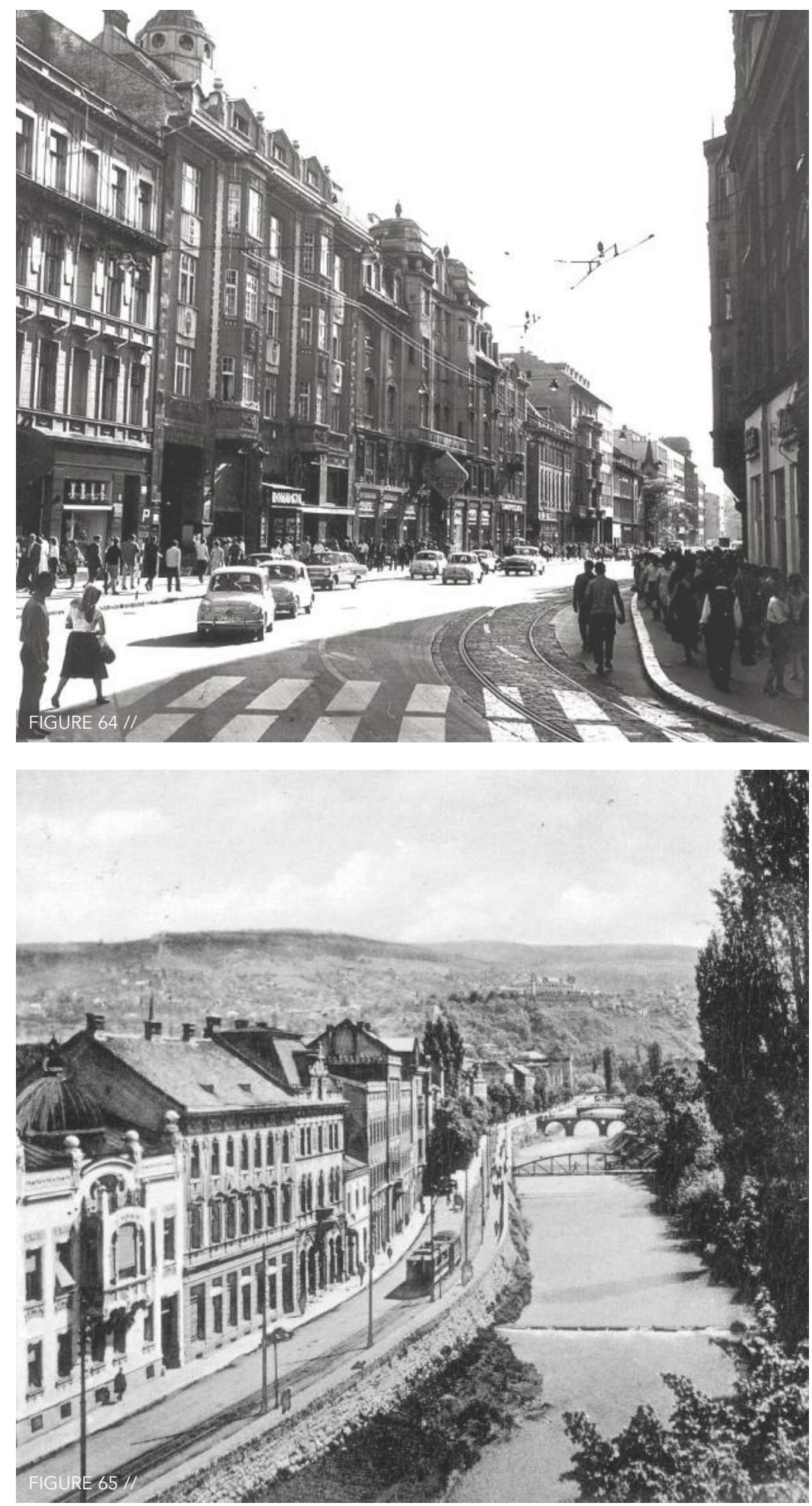

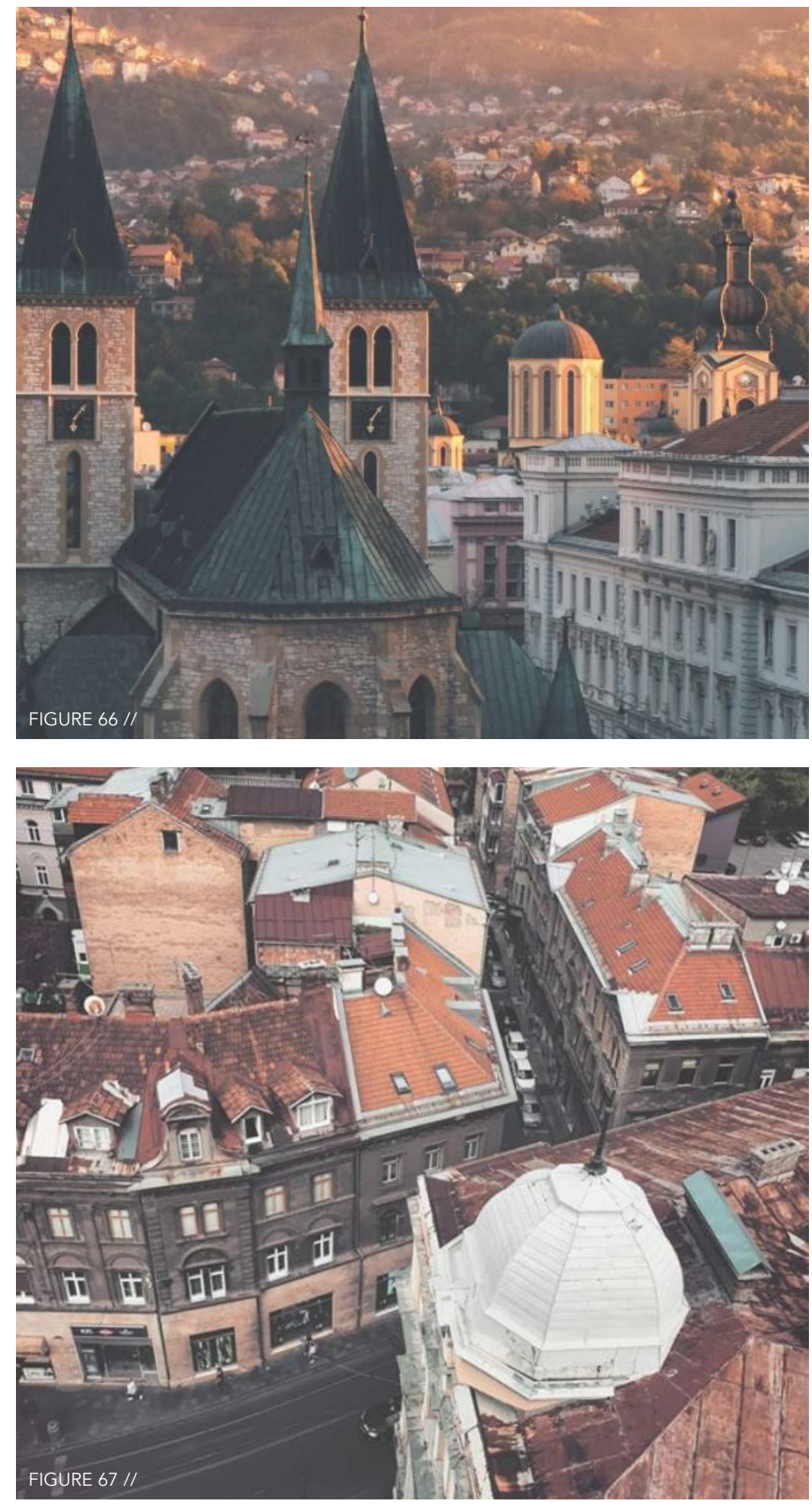
years, and began operating electrically in 1895. Regardless of its efficient expansion of Sarajevo, "the Austro-Hungarian regime was envisaged to communicate with the general population only at the level of exterior appearance and façade décor." It did not in fact invite everyone, and the accessibility of its space was "limited as a privilege of the elite, for the rich and powerful." " Socially, this represented itself as a public life that involved seeing and being seen, and public spaces that allowed this opportunity.

Austria-Hungary made substantial effort with its new inheritance and intended to exploit Sarajevo's many natural resources, especially its timber and mineral wealth. Before this could happen, Archduke Franz Ferdinand, heir to the Austrian throne, together with his wife Sophie Chotek, was assassinated on a visit to Sarajevo in 1914. This erupted into WWI, and the empire collapsed. 
During the interwar period, $\mathrm{BiH}$ was united with the Kingdom of Yugoslavia, under the Serbian Dynasty family of Karađorđević. Yugoslavia, derived from 'yug' meaning south, translates into 'the land of the south Slavs'. It consisted of the six republics of BiH, Serbia, Croatia, Slovenia, Montenegro and Macedonia. Throughout this time, Sarajevo was completely disregarded as anything of value, and turned into a provincial centre deprived of energy and culture. The centralized and unitary state "could not tolerate BiH's aspirations for autonomy and a country complete within its historic boundaries." ${ }^{5}$ Despite this, several dozen buildings influenced by Modernism and the Bauhaus movement were erected in Sarajevo, adding to its valuable architectural heritage. When WWII arrived it descended upon Sarajevo in the form of the German-Ustaša occupation for four years of relentless tyrannical regime, until its eventual liberation on April 6, 1945. Led by Josip Broz Tito, a communist Yugoslav politician, the victorious Partisan guerrilla army fought the most effective anti-Nazi resistance movement that put an end to the National Liberation Struggle. This military success would have never been possible without Tito and the affirmed morality and humanity of the Partisan men. Following a short three-year alliance with Joseph Stalin's Union of Soviet Socialist Republics (USSR) in the post-war period, Yugoslavia's new socialist state pursued an independent brand of socialism, "becoming the torchbearer of a 'Third Way' in the bifurcated world of the Cold War." 6

The birth of the SFRY marked a new history for all its nations and nationalities - this complex genesis of three nations is specifically the Bosnian \& Herzegovinian phenomenon. Quickly becoming the revolutionary symbol in Yugoslavia, Tito was "a triumphal arch between the dark and bloody walls of medieval past and the road to civilization." 7 Tito deliberately defied 
the geopolitical East-West divide by pursuing friendly cultural connections and economic exchanges from both rival blocs. Despite the difficulties of a non-democratic regime, as well as the controversial opinions that surround his leadership decisions today, at the time Tito's vision promised a new era of 'bratstvo i jedinstvo' [brotherhood and unity]. After he won a presidency election outlawing other parties, a period of intense construction began. The faith of religion was replaced by the faith of Slavic brotherhood, unity and self-management. Memorial sites, monuments, and cultural and social homes promptly succeeded religious symbols and places of worship.

The pragmatic expansion of the city into new neighbourhoods notably materialized in Novo Sarajevo [New Sarajevo] and Vojničko Polje [Military Field] in response to pressing housing needs (Figures 68-71). During this period, Sarajevo also became a highly reputable university city, an important industrial, trade and communications centre, the seat of the Academy of Arts and Sciences, and the home of prestigious cultural and sporting institutions. Tito nationalized businesses and industries in a manner similar to the Soviet system based on state ownership of production, farming, manufacturing and administrative planning, but managed to maintain autonomy from the USSR. In the midst of this, Tito decided that the Marijin Dvor district of the city, built during the Austro-Hungarian Empire, had the capacity to spatially connect the old town to the new, marking the transition in the city from historical east, to the urban west. With the city expansion, Marijin Dvor was appointed the administrative and cultural centre of the city, and also acted as "an economic shopping centre that gave this part of town the necessary urban liveliness."

The socialist peak of Sarajevo's cultural life began influencing the recreational needs of people, and as such people began needing spaces for performance, arts, social and recreational activities (Figures 72-75). Architecture began expressing universal and international values that promoted Yugoslavia as an open and diverse country, which was different 

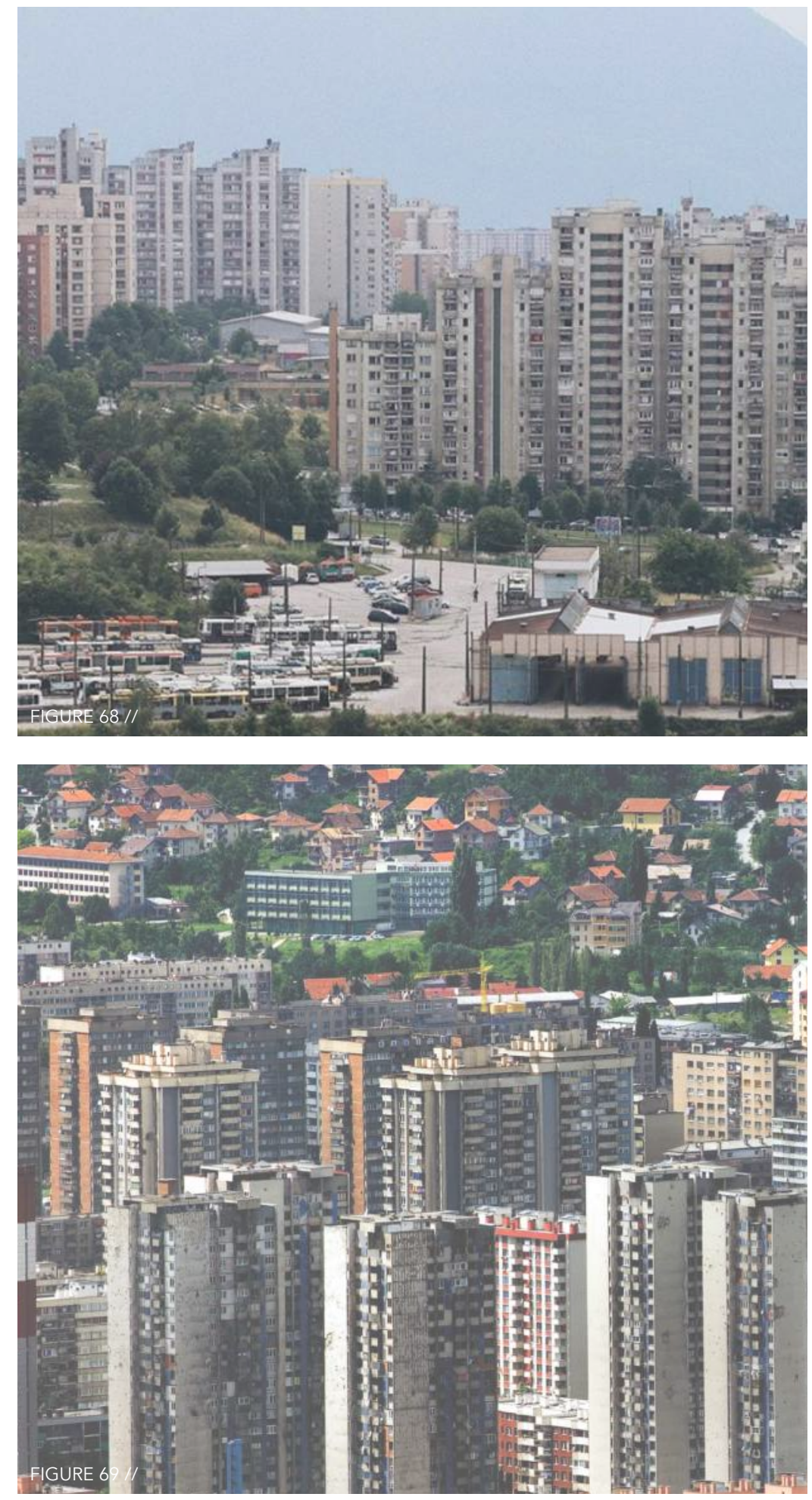

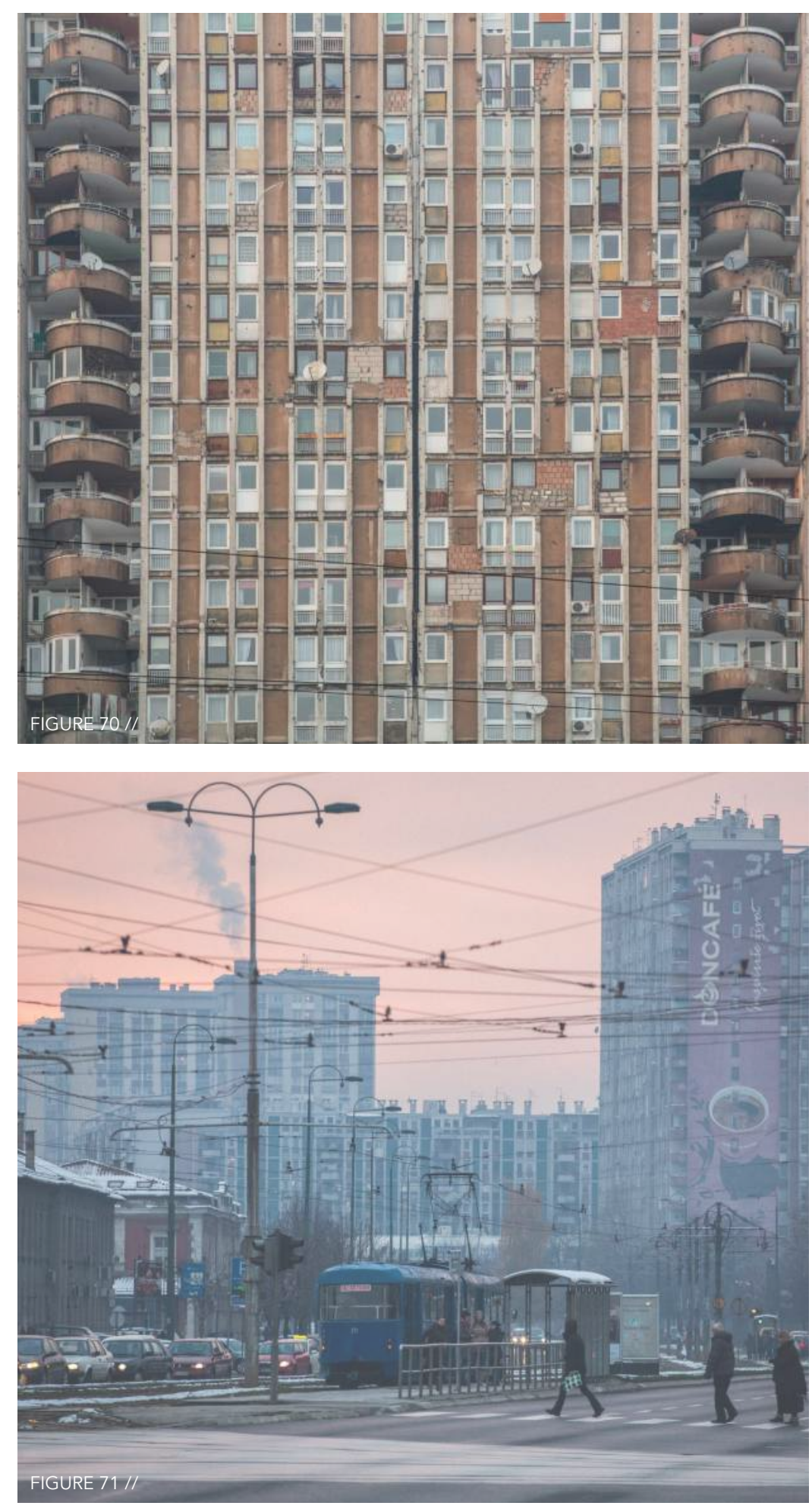

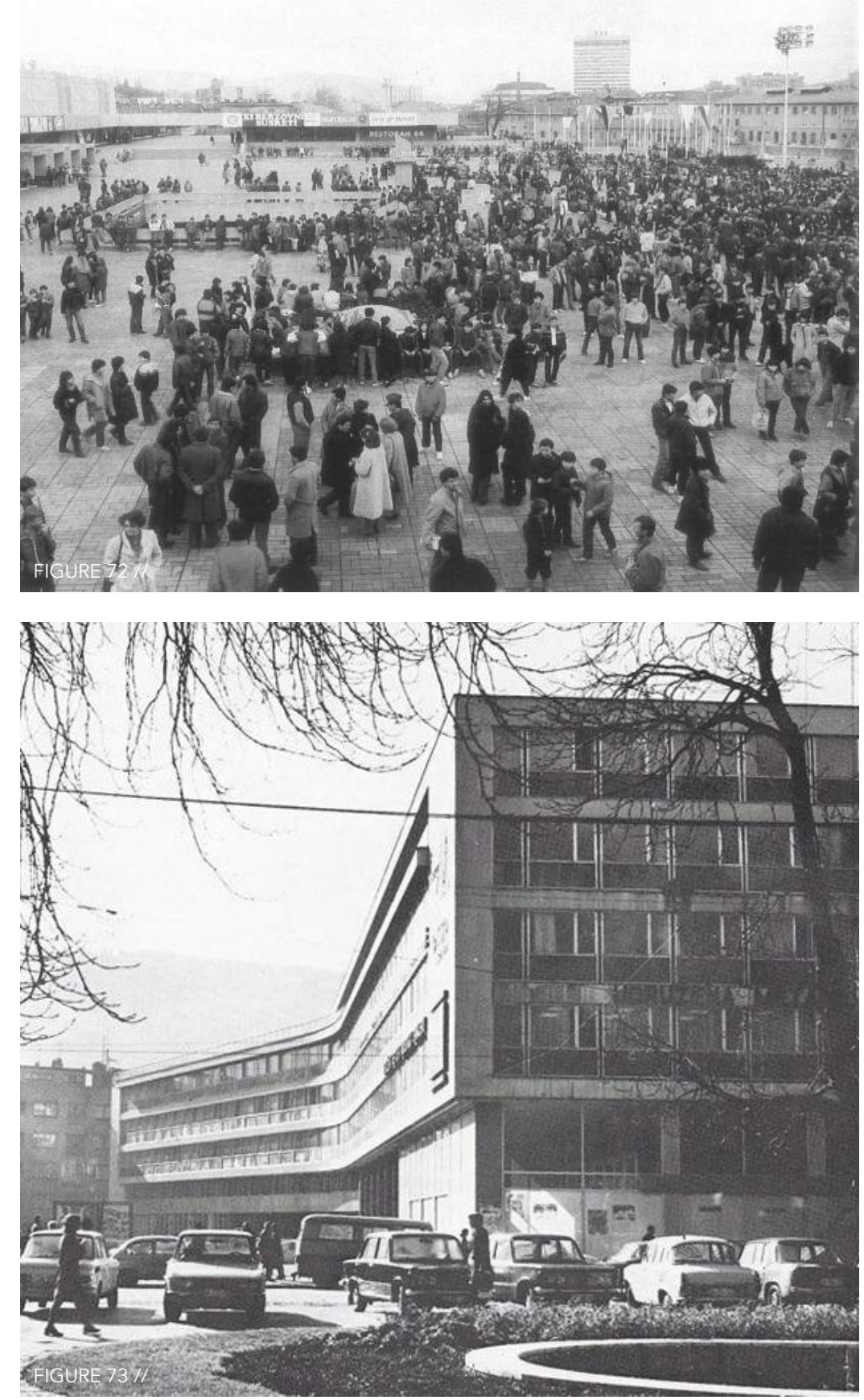

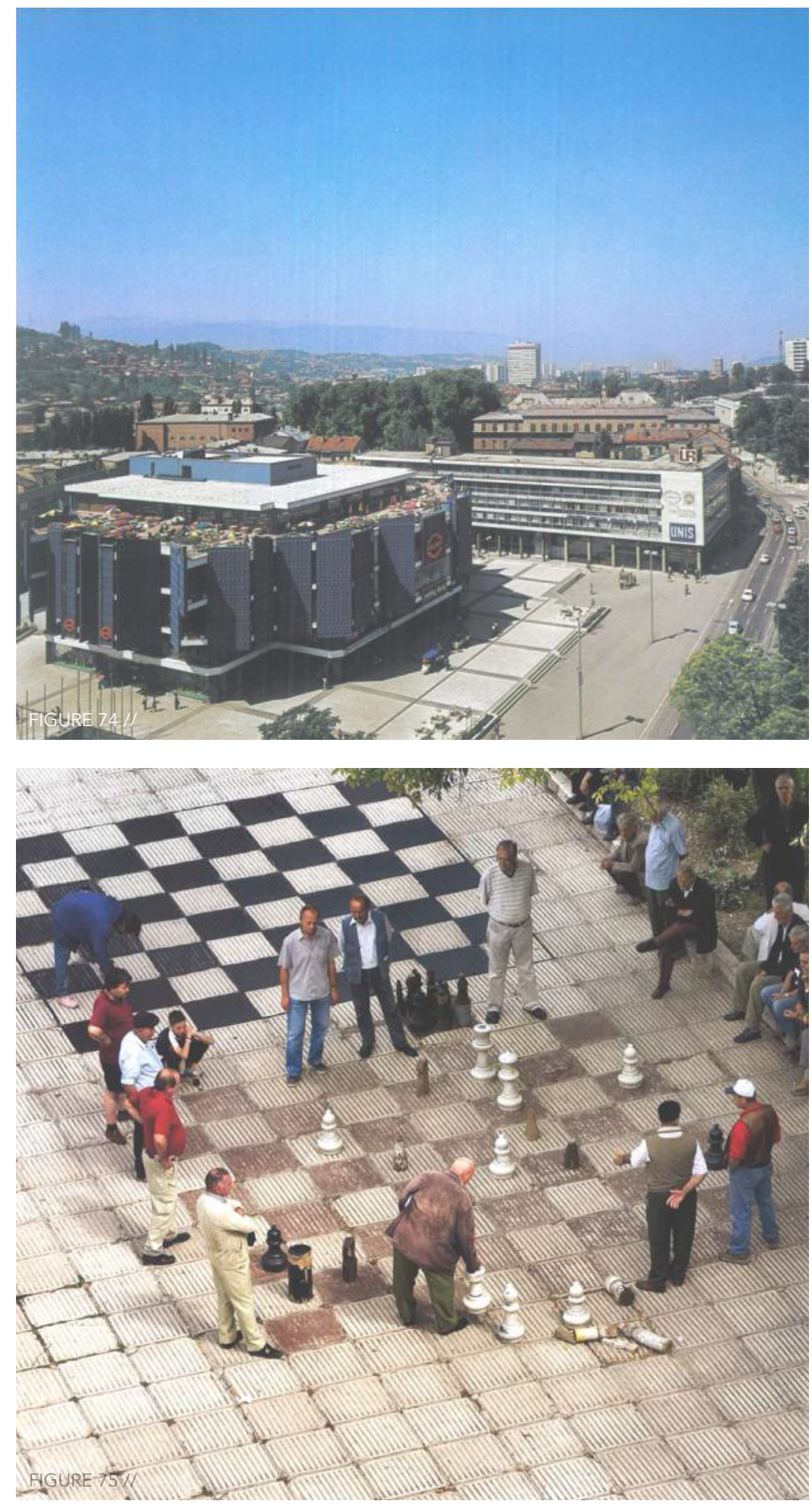
from other communist states. This philosophy was embodied architecturally in new representational typologies, often categorized under social, cultural and sports homes or centres. Tito appreciated sports, entertainment and culture, and saw these as effective tools for influencing the nation towards equal diffusion for all - 'culture for all.' These "polyvalent institutions were designed for large gatherings with the goal of promoting national unity and controlling the socio-cultural life." ${ }^{\prime 9}$ The most representative of these institutions was Tito's KSC Skenderija.

Built in 1969, Skenderija was "a unique architectural achievement in Yugoslavia" 10 that exemplified the specific form of cultural and social hybridity. It integrated culture, sport, leisure, commercial, and entertainment services all under one roof. According to architect Duško Bogunović, the architecture of Skenderija reflected pure international style with emphasis on horizontality, strong mass-void opposition, an open plan and the excessive use of 'béton brut'. In this form, the application of raw concrete with strong, clear modernist lines "connoted the principles of simplicity, honesty, equality and openness to every citizen." "'l Skenderija's symbolic importance to the city and its citizens grew in 1979 when Sarajevo was awarded host city to the Winter Olympic Games of 1984, and an expansion project of the complex was set in place for the addition of an ice house.

When Tito died in 1980, the SFRY was placed under another communist regime where power was rotated within a state presidency that consisted of one representative from each of the six republics. Despite the early 1980s being seen as the glory years of Sarajevo, the new state system gave way to growing political instability, which led to the increasing desire in most republics for independence and democratization. At the intersection of opposing worlds, the entire history of this land is "characterized by two forms of a single trend; exposure to domination and conquest from without, and permanent resistance from within."12 With the fall of communism and the reintroduction of free elections in 1990, the official dissolution of the SFRY followed in 1992. 


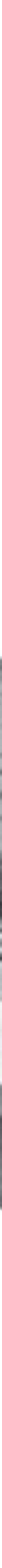




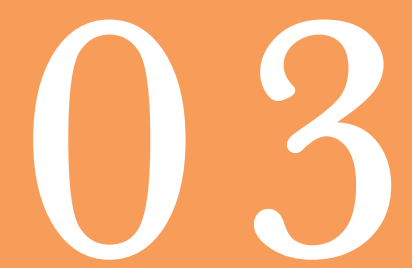

// INTERPRETATION OF PLACE

Zajednički Život

A Cultural Profile

A Social Dialogue 


\section{ZAJEDNIČKI ŽIVOT}

// HOME-MAKING

During the siege, many Sarajevans thought of home in a number of ways outside the apartment. Whether they were displaced from their area of town due to heavy shelling, or whether home was the basement of their apartment block where they would spend hours, sheltered with their family and neighbours. This sense of safety created a sort of community, despite the different ways of coping. Whether it's an apartment, a basement, a café, a restaurant or a park, a city and its spaces become home when inhabitants physically and symbolically appropriate them. Today, Sarajevo is considered home to those who stayed during the war, those who left and came back, and those who sought refuge and opportunities elsewhere in the world. Since the end of hostilities, the rebuilding of Sarajevo was made possible with generous donations and assistance from international organizations and foreign governments. Immediately after the Dayton Peace Agreement, six billion dollars was allocated for the reconstruction of roads, bridges, and schools, the restoration of Sarajevo's electrical and plumbing infrastructure, and the repair of red-tiled roofs on most homes. Now over 20 years since the end of the war, this initial reconstruction was what geographer and social scientist Gruia Badescu calls a step in recovering 'normality', be it through "recreating the familiar or by simply moving forward."

Following the reconstruction of a post-war city, challenges of a destroyed built environment are manageable when compared to those of a traumatized population. For Sarajevans, there's no doubt that Sarajevo is not and will never become the city that it once was before the war. This thesis begs the question of what can still be done for the recreation of moments within the city, whether architectural, cultural, or emotive, in order to re-establish a collective memory that characterizes Sarajevo and its people. Within this, inclusive public spaces must be present, promoting interactions and deeply 
concentrating on 'place-making'. This enables communities to engage with the past while creating meaningful futures. The rebuilding of a space can be as symbolic as the destruction that caused it, permitting "construction to weave the fabric of a former life back together," ${ }^{2}$ and in doing so, new precedents for collective memory form.

Sarajevo's distinctiveness has always lied within "its ability to organically absorb different cultures and traditions, allowing life to flourish without exclusion."”3 If necessary, it would only require one day to see hundreds of examples of ethnically mixed interconnections of people, forms and ideas. Bosniaks, Serbs and Croats interact socially, work together harmoniously and often marry each other. During the post-war reconstruction efforts of the city, only the report from "Sarajevo-based institute for the protection of cultural, historical and natural heritage of Bosnia \& Herzegovina mentions the destruction of architectural legacy of all sides - Bosnian, Croatian and Serbian." "This is a strong reflection of Sarajevans' "commitment to multiethnicity - their cultural self-identity as Bosnians depends on preserving this cosmopolitanism, ${ }^{, 5}$ which is expressed in BiH's architectural pluralism. This notion of cosmopolitan tolerance continues to predicate BiH's identity through its reconstruction and 'home-making'. 


\section{To Americans, who}

create the world's most

popular films but look on the medium as a weekend diversion

that can easily be done without, Sarajevo's kind of intense, almost heartrending passion for film has to be unexpected, almost disconcerting. 


\section{A CULTURAL PROFILE}

// ART STANDS FOR HOPE

Even in the worst of times, cultural life did not stop in Sarajevo. Thanks to Josip Broz Tito, a special part of cultural production in $\mathrm{BiH}$ will always belong to the theatre and film industry. As Tito had an elevated personal appreciation for culture and entertainment, the SFRY became a workshop for the merriment of different ethnicities under one nation by means of media, theatre, film, education and architecture. Movies portrayed in the two decades following the end of WWII focused on themes of national revolution, famous partisan battles, and WWII. Notably, the first screening of 'Battle on Neretva' was ceremoniously showcased at KSC Skenderija's opening night.

Taking place annually in Sarajevo, MESS is known as the oldest experimental theatre festival in all of the Balkans. It was founded under the socialist regime in 1960 with the official name 'Festival Malih i Eksperimentalnih Scena Jugoslavije' [Festival of Small and Experimental Stages of Yugoslavia]. At its conception, it was simply an annual gathering of Yugoslavia's professional theatre companies, with the goal of performing the greatest experimental theatre pieces of that year. Quickly acquiring international attention from similar theatre companies, the concept grew into one of the four major annual showpiece platforms. During the siege of Sarajevo, MESS relaunched as a cultural resistance project, resulting in the organization of the first film festival in 1993; titled "After the End of the World" (Figure 77). Today it's known as the Sarajevo Film Festival (SFF).

Sarajevans believed that art stood for hope during the war, which is why capable citizens decided to fight the destruction of their city with creativity. As a result of this cultural defiance, remarkably theatre and film were thriving industries. Chamber Theatre 55 and Sarajevo Youth Theatre continued to 
operate. Additionally, Mirsad Purivatra and his wife, who founded Obala Theatre Group in 1984, established a small cinema theatre in the basement of the University of Sarajevo's Dramatic Arts Academy building in 1992. Sporadic word-of-mouth film screenings were held on a small theatrical stage that "was reshaped into a cinema theatre by adding a VHS player, a projector and a few additional seats." ${ }^{\prime \prime}$ Old VHS tapes were donated by journalists who had successfully acquired UNPROFOR press cards, which enabled them to use transport aircrafts on their back and forth routes to the military base and humanitarian logistical centre. ${ }^{2}$ Despite being a war cinema with one hundred seats accessible only through a bombed-out hole

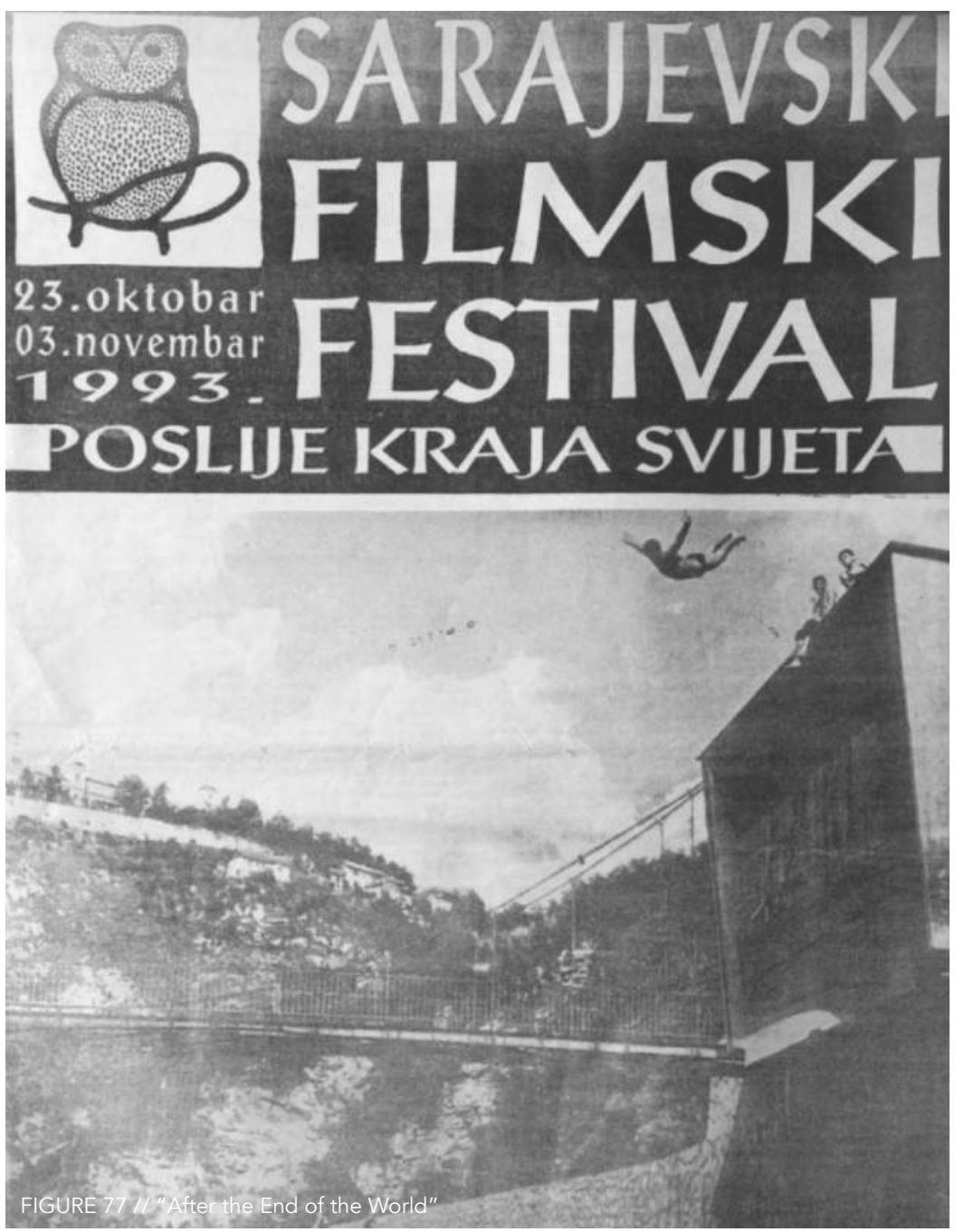



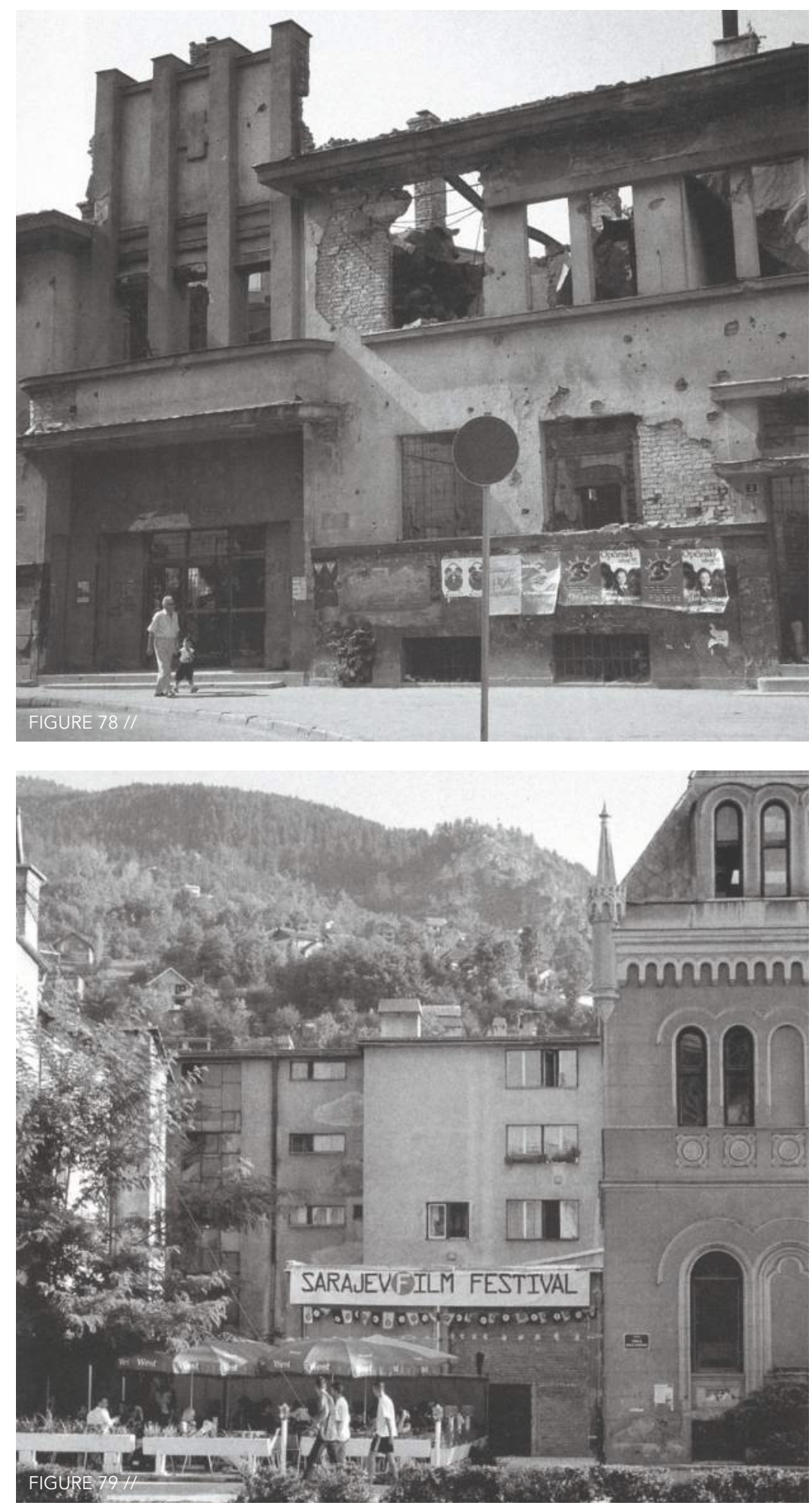

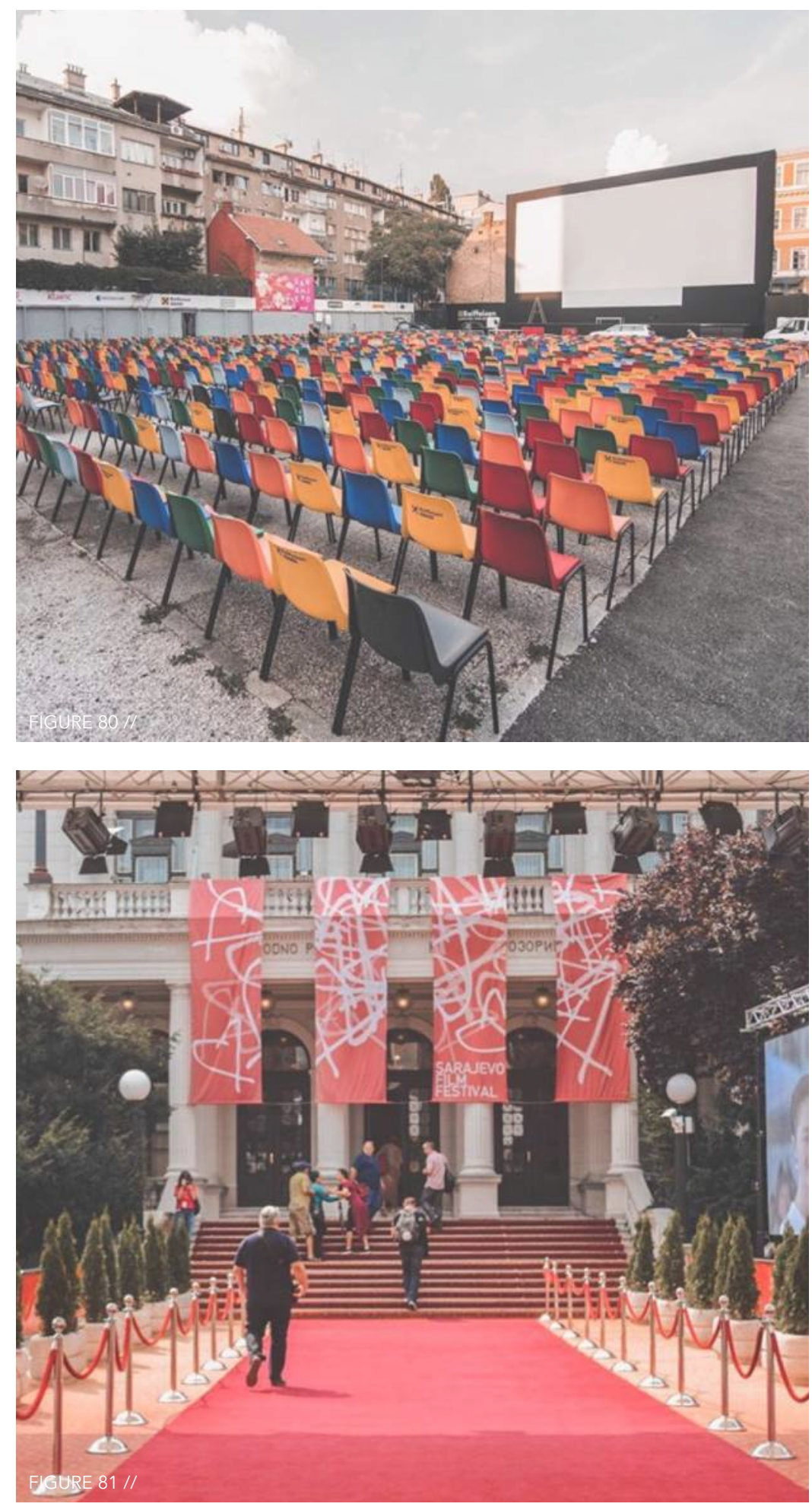
in its surrounding wall and despite the shelling, the theatre was packed every single night there was a showing. The price of a wartime cinema ticket would be near impossible to compare to present day fees, considering Bosnian currency during the siege resembled nothing more than pieces of paper. It wasn't until the first SFF in 1993 that a permanent price was established: seven cigarettes. Throughout the war, cigarettes were used as alternative currency and paid for all sorts of things. Whether you needed food for your family, diapers for your baby, or a Volkswagen Golf - the vehicle would have cost you three cartons of cigarettes.

There was no running water, no electricity, no fuel and extremely limited amounts of food, yet under these circumstances, the SFF "was established as a genuine 'child of war."'? Going to the movies during the war was an act of defiance; it was "proof that the city and its residents were unapologetically alive." "Today, the bombed-out wall whose hole created the entrance to the war cinema, now Obala Art Centre, frames the perimeter of SFF's openair theatre space (Figure 80 ). The damaged wall has only been partially repaired and serves as a discreet reminder for what began as an initiative of reconstructing civil society, evolving into the birth of SFF's cultural identity, and retaining the sophisticated spirit of the city. Post conflict, there was an intense desire to quickly return to a rhythm of everyday life with daily routines. So when the first 'official SFF' was held following the ceasefire in 1995, there was a surprising 15,000 in attendance - today, the event attracts more than 100,000 annually. It is presently the leading film festival in southeast Europe, and is internationally recognized by viewers and professionals as such. In addition to the main events, SFF holds lectures and workshops by world cinematographers for the duration of the festival, providing film students from across the region with foundational knowledge and opportunities to showcase their talent.

Besides theatre and film, Sarajevans show their strength of character in other artistic ways. In contribution to the cultural resistance movement, the 
Ars Aevi Contemporary Museum of Art was established during the first year of the siege; its founding idea was born the same night the original 1984 Winter Olympics Museum was shelled and burned to the ground. Meaning 'Art of the Epoch' in Latin, and hiding the word 'Sarajevo' in it, Ars Aevi was an initiative that promoted intercultural dialogues and hoped to unite by the universal language of art. It seemed unnecessary to make future plans for museums without knowing if you would be alive from one minute to the next. However, the idea was supported internationally and neighbouring cities with their museums donated pieces of contemporary art out of solidarity to the people of besieged Sarajevo; these 150 pieces form the collection. Located in Dom Mladih at Skenderija, Ars Aevi has remained open for the public throughout all these years.

Through impressive efforts of collective will, Sarajevo was not just $a$ city under siege; it became the city under siege. The city, in spite of being under attack, capable of taking violence and ignorance and turning it into a symbol of their cultural defiance through tolerance. As a result of this, "if Sarajevo was not a focal point for cultural events before the war, it definitely became a cosmopolitan place because of it." ${ }^{{ }^{5}}$ With the inclusion of the SFF, this thesis allows the opportunity for further expansion, while providing urban and architectural spaces for use throughout its festivities in maintenance of its cultural and urban qualities year round for Sarajevans. 


\section{Sarajevo is a geography of the soul.}

// Author 


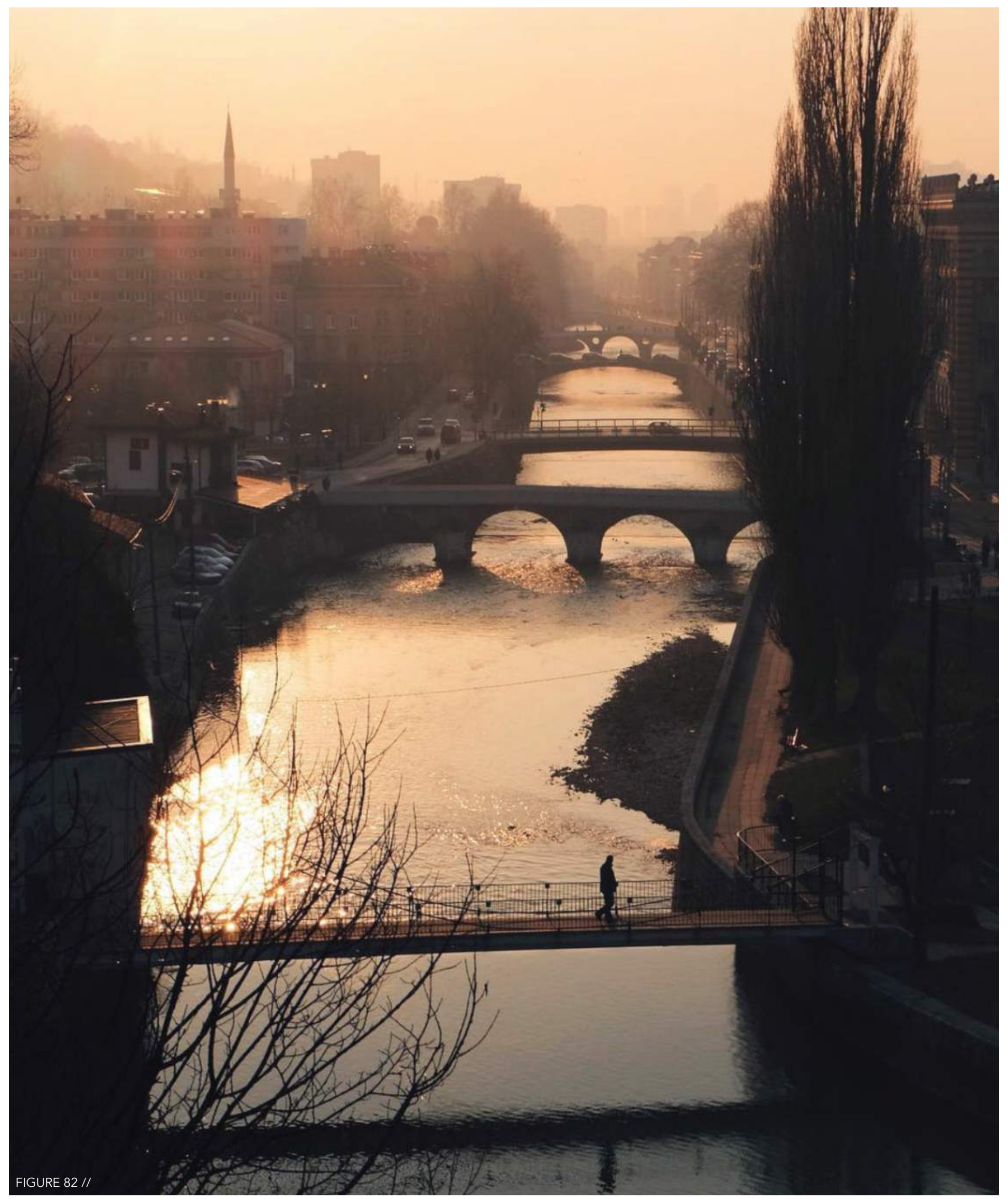




\section{A SOCIAL DIALOGUE}

// A WALKING CULTURE - A COFFEE CULTURE

The relationship between an individual and the places they frequent are susceptible to the way they navigate their environment. Through walking or biking, a strong connection with their surroundings is likely to materialize, whereas vehicular roads are built for transit and not connected to the activity zones within a city. Sarajevo is a great city for walking, nearly impossible to get lost in. If you don't know where you are, all you have to do is go downhill until you hit the river, "and from there it would all be obvious. If you got tired, you could sit in a café and have a coffee, or, if you were hungry, stop at a small restaurant for a meat pie." It's not a pretentious or glamorous city, but it is welcoming and charming, filled with tasty food, good coffee and a spirit that will stir the hearts of everyone who walks its streets.

Sarajevo is an experienced, rather than an imagined, community. Defined by the surrounding hills that form the city, Sarajevo's internal landscape is Baščaršija as the heart, vegetation as the lungs, and the river as the spirit, with its public life largely concentrated within the one kilometre space to either side of the river. The Miljacka River and its many bridges run through the centre of the city, enthralling the attention of each pedestrian. Ivo Andrić, a Yugoslav novelist who won the Nobel Prize in Literature in 1961, considered Miljacka as the spine of Sarajevo, with its bridges, the city's vertebrae. The newest addition is the Festina Lente Bridge, or in Bosnian 'Požuri Polako' [hurry, but slowly]. This enigmatic phrase perfectly captures "that particular Sarajevan mind-set of intensity done at a leisurely pace.”2

The cultural tradition of walking the street is central for the local experience; the unhurried evening strolls in Sarajevo are a social experience in themselves, meeting and greeting people you know along the way. People come out to see and be seen, taking in the rhythms of life happening around 

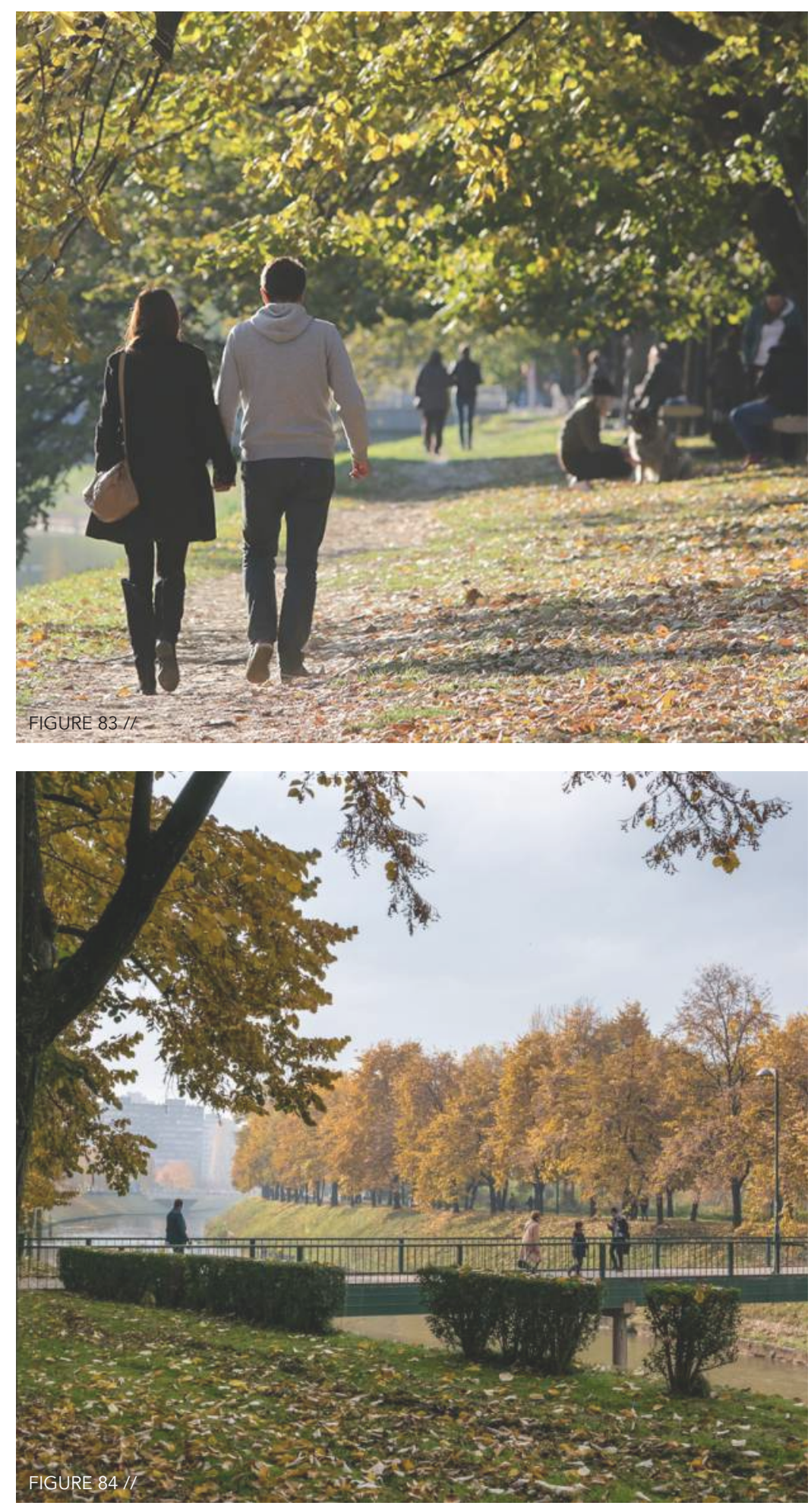

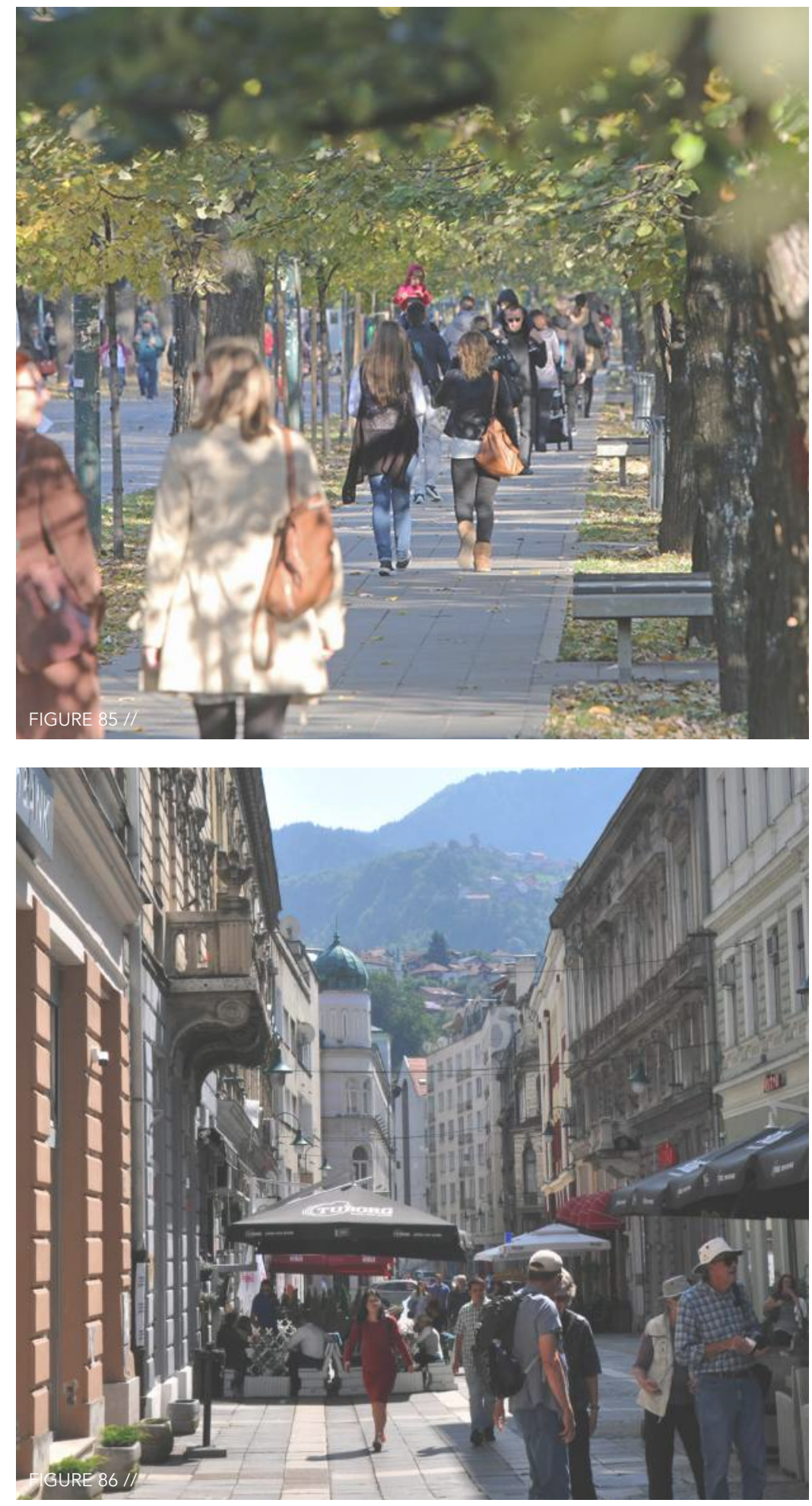

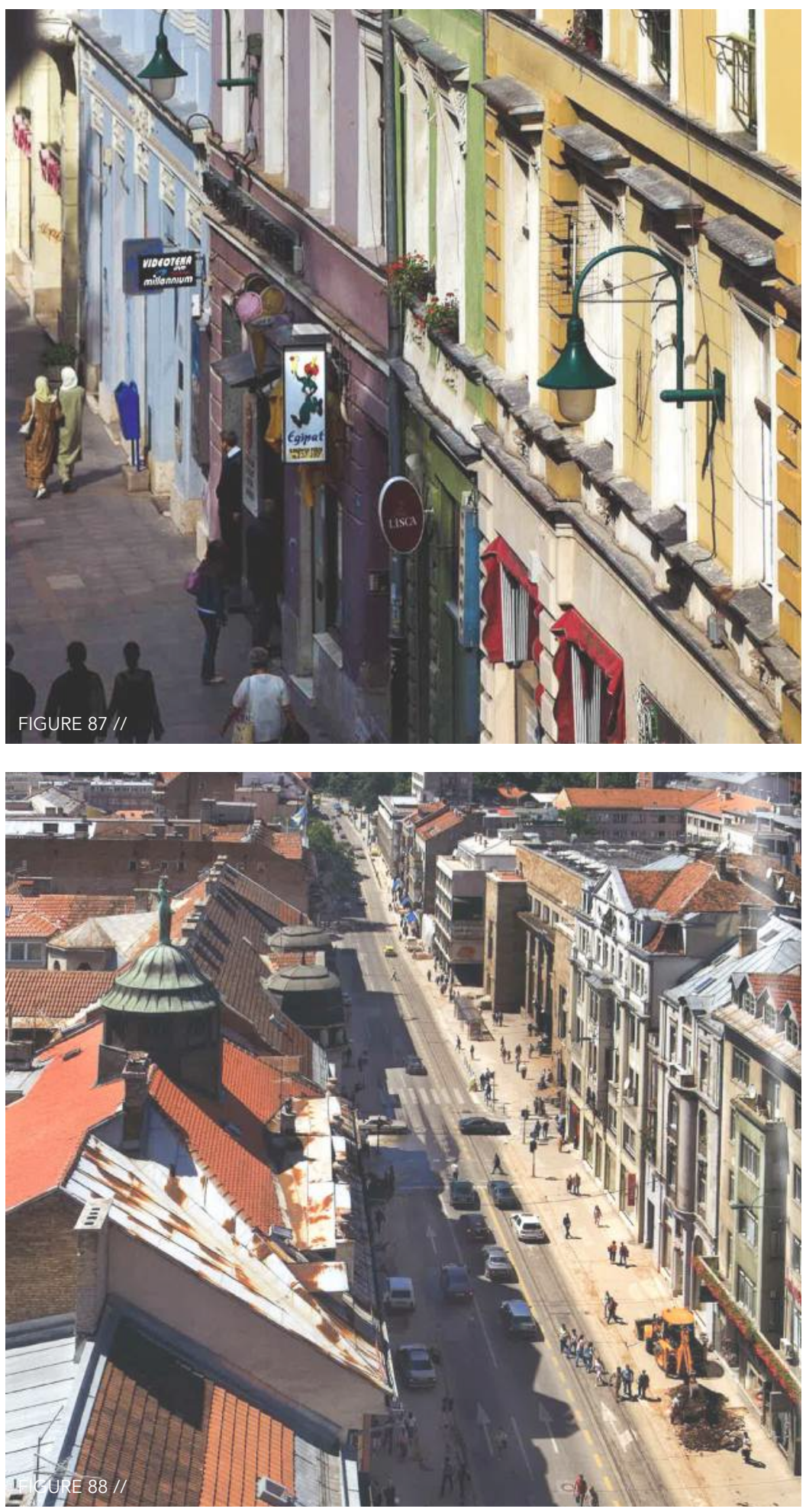
them. Sharing the walkways and streets of the old town, the rituals were always the same: you meet at Vilsonovo Šetalište, walk towards Ferhadija Street and when you finished going up and down as often as you pleased, you'd join the rest of the city at any one of the sidewalk kafanas [cafés] that had room for you. The term 'raja', translating into a crowd or a group of friends, is a fundamental aspect of the Bosnian social life. The culture of sidewalk kafanas is people watching or being people-watched. Whether you're a local or a tourist doesn't make a difference, this rampant social activity is an intrinsic part of your late afternoon or early evening routine.

Vilsonovo Šetalište (Figures 83-85) and Ferhadija Street (Figure 86-87) are two contrasting yet vital pedestrian streets in central Sarajevo. Vilsonovo Šetalište, starting at Dolac Malta neighbourhood in socialist Novo Sarajevo, stretches east along Miljacka River towards Marijin Dvor and Skenderija. Lined with kafanas and restaurants, parks and workout equipment, young and old alike consistently flow through varying activities. Enveloped by thick beautiful trees on both sides, the road is closed to vehicular traffic every weekday after 5:00pm, and all weekend long. Because of its proximity to the front line during the siege, when the city's park trees were all being cut down out of desperation for warmth, Vilsonovo Šetalište survived, untouched. On the other hand, Ferhadija is a $16^{\text {th }}$-century pedestrian street stretching from downtown to the heart of old town. It is the meeting of East-West cultures and was the main thoroughfare during the Austro-Hungarian city. It connects to Maršala Tito Street (Figure 88) on one end and Baščaršija (Figures 89-90) on the other. Resembling a river of humanity, Ferhadija can be referred to as 'the city's 'artery,' because if you spent enough time drinking coffee at one of its many kafanas, the whole city would eventually circulate past you."

The many kafanas lining the streets of Sarajevo are critical to the city's rhythm, dictating a large portion of social interactions and the fabric of how people interrelate each day. With coffee being the backbone of BiH's social 

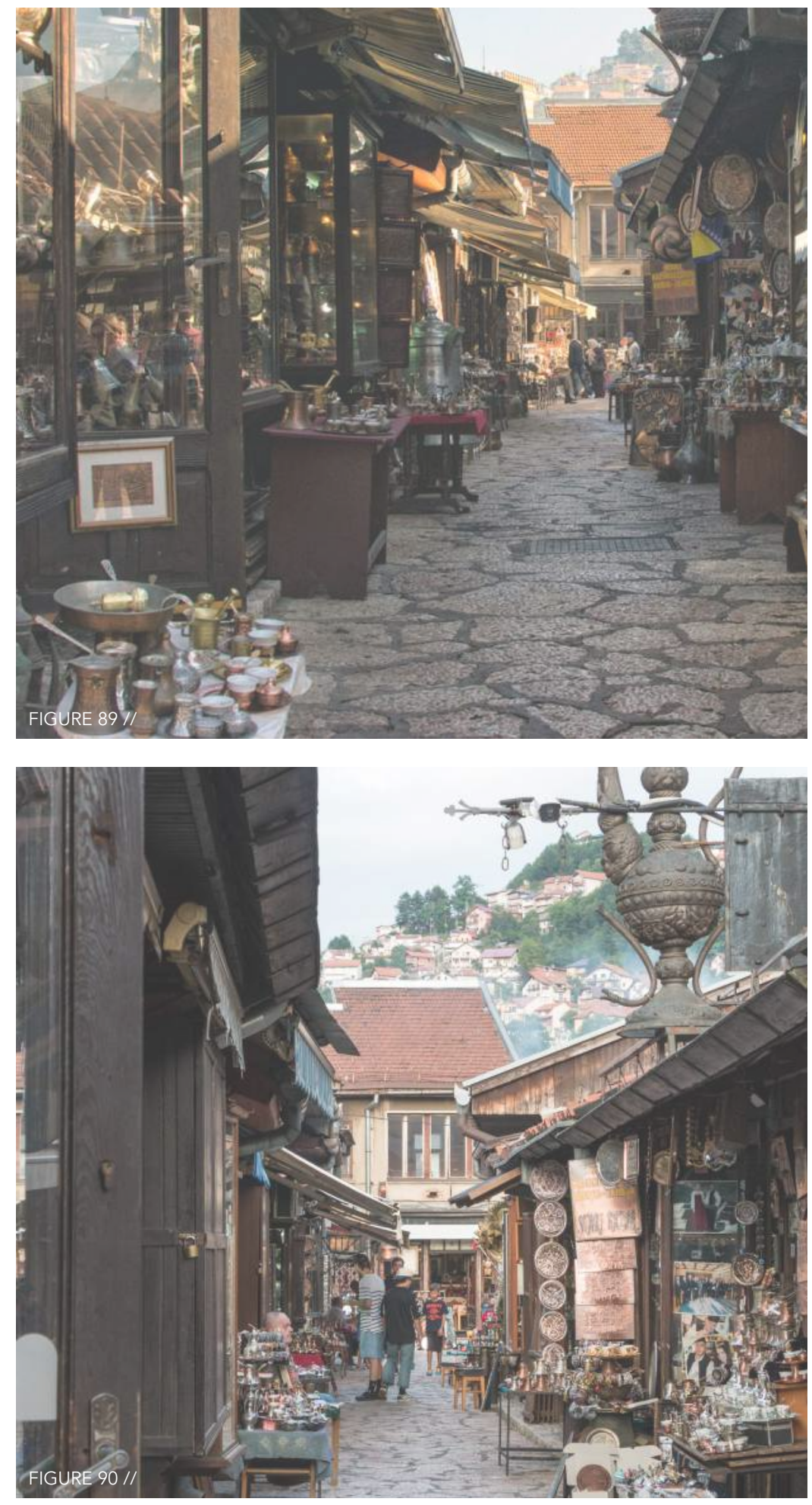

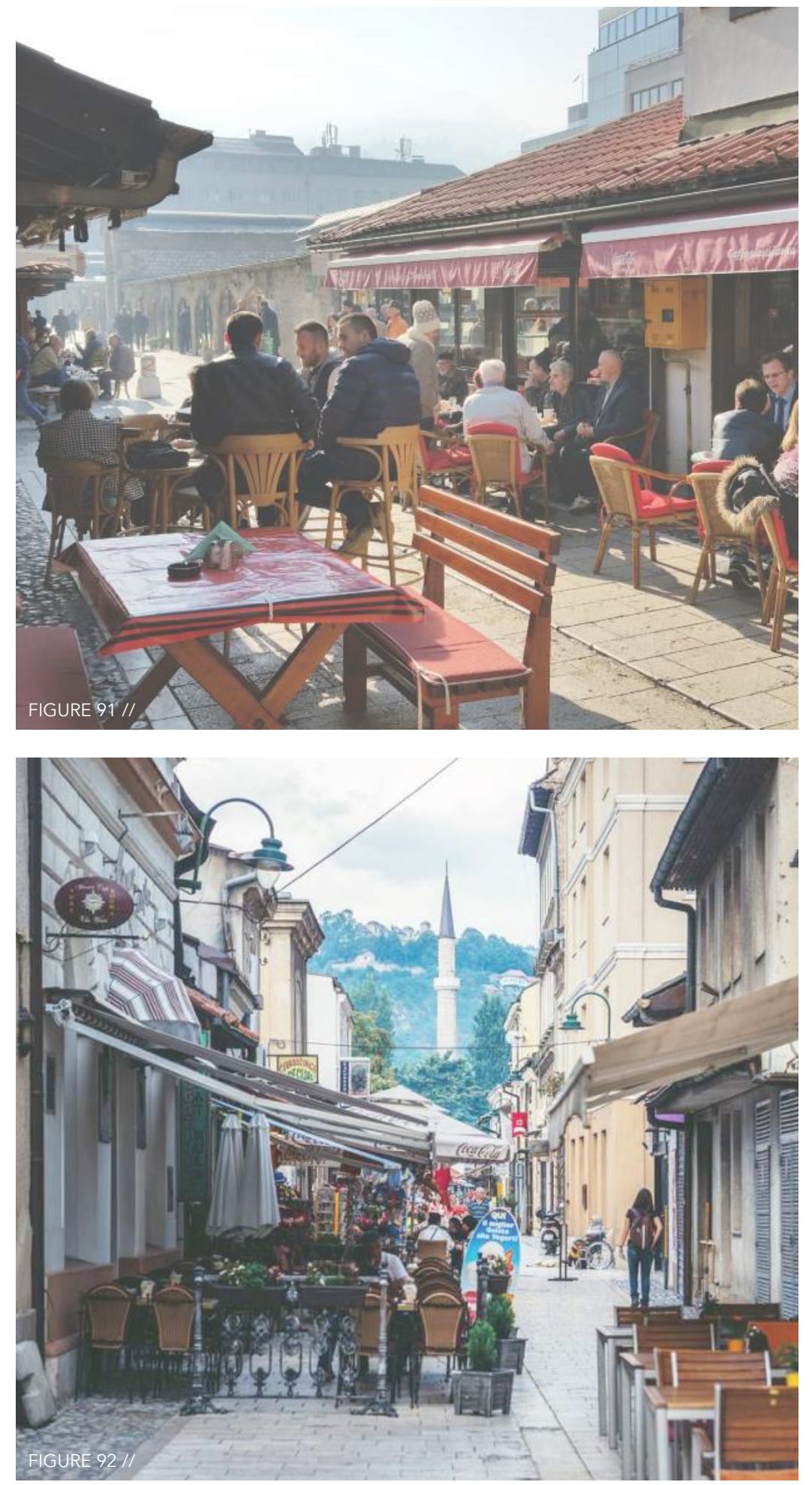

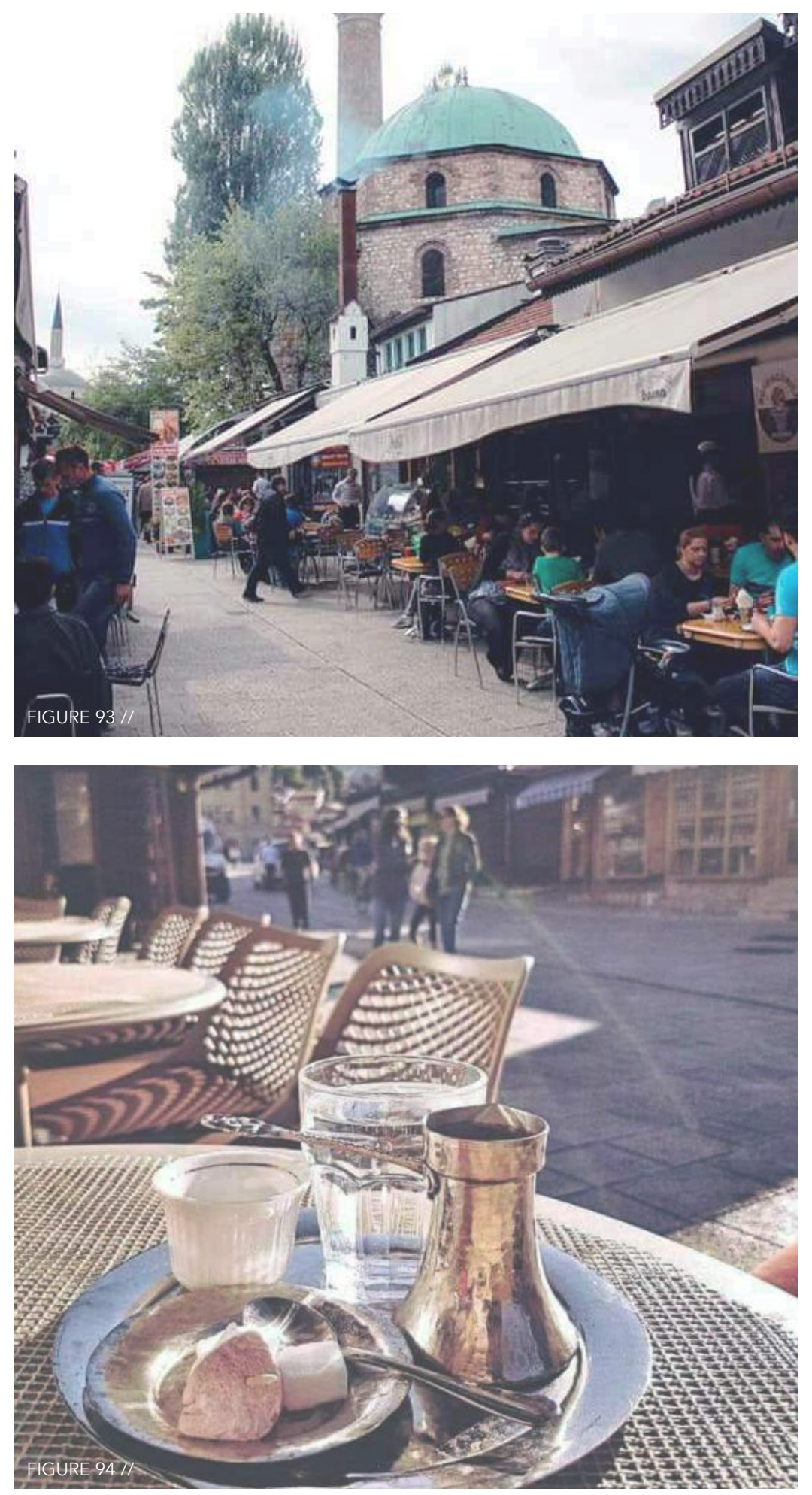


\section{6}

We have no money

here, but what we do

have is time. It is not

uncommon to sit in a

café all day, meeting one

friend after another.

We have time to think

about life. 
life, it's no surprise that Sarajevans will sit for hours in front of a cup, in one of the multitudes of umbrella-ed kafanas, just making conversation (Figures 91-93). In the morning, the first cup is always taken at home, but throughout the day the amounts of coffee breaks that can be taken with friends are endless, regardless of if you are thirsty for one. As communication in all spheres of life is integral in the Bosnian culture, Bosnian coffee is viewed as an initiation to a conversation. Being very social and hospitable, Bosnians enjoy hosting and entertaining guests at home where coffee is served three times: the first coffee is called dočekuša, meaning 'welcome coffee'; the second coffee is called razgovoruša, meaning 'talking coffee'; and when the third coffee, called sikteruša, is served, guests know it's time to go home.

Often interchangeably referred to as Turkish coffee, Bosnian coffee differs in the ways it's prepared, served, and consumed. While both prepare their coffee in a long-necked copper pot called a džezva, Turkish coffee is made with cold water and coffee grounds brought to a boil together and then placed on the stove again. Bosnians bring water to a boil before pouring it overtop of the coffee grounds, and then it is brought to a boil again. In Turkey, the džezva stays in the kitchen and your coffee is brought to you in a single cup. Meanwhile in Bosnia, the whole džezva, containing about three cups, is placed on an iron tray with an empty cup, a glass of water, a dish of sugar cubes, and a 'rahat lokum', often mistaken for a Turkish delight candy (Figure 94). Traditionally, sugar should not be added directly to the coffee as it is in Turkey. In Bosnia, you take a bite of the sugar cube, place it under your tongue, and then sip the coffee, allowing the sugar to dissolve. Despite the differing characteristics, there is one thing that remains the same between both traditions: while a cup of Turkish or Bosnian coffee may be smaller than you're used to, it's definitely stronger.

In a country where the wounds of atrocities are still fresh in its collective memory, having a national identity gains further importance. With coffee culture being an irreplaceable part of Sarajevo's, it's "refreshing to think 
that while most of the world's people are racing to some invisible finish line, Bosnians seem to take a little time to enjoy the small things in life." Its physical beauty is what first draws you to Sarajevo, but it's the people who make you fall in love. This thesis places heavy emphasis on Sarajevo's cultural way of thinking, moving, and being. 


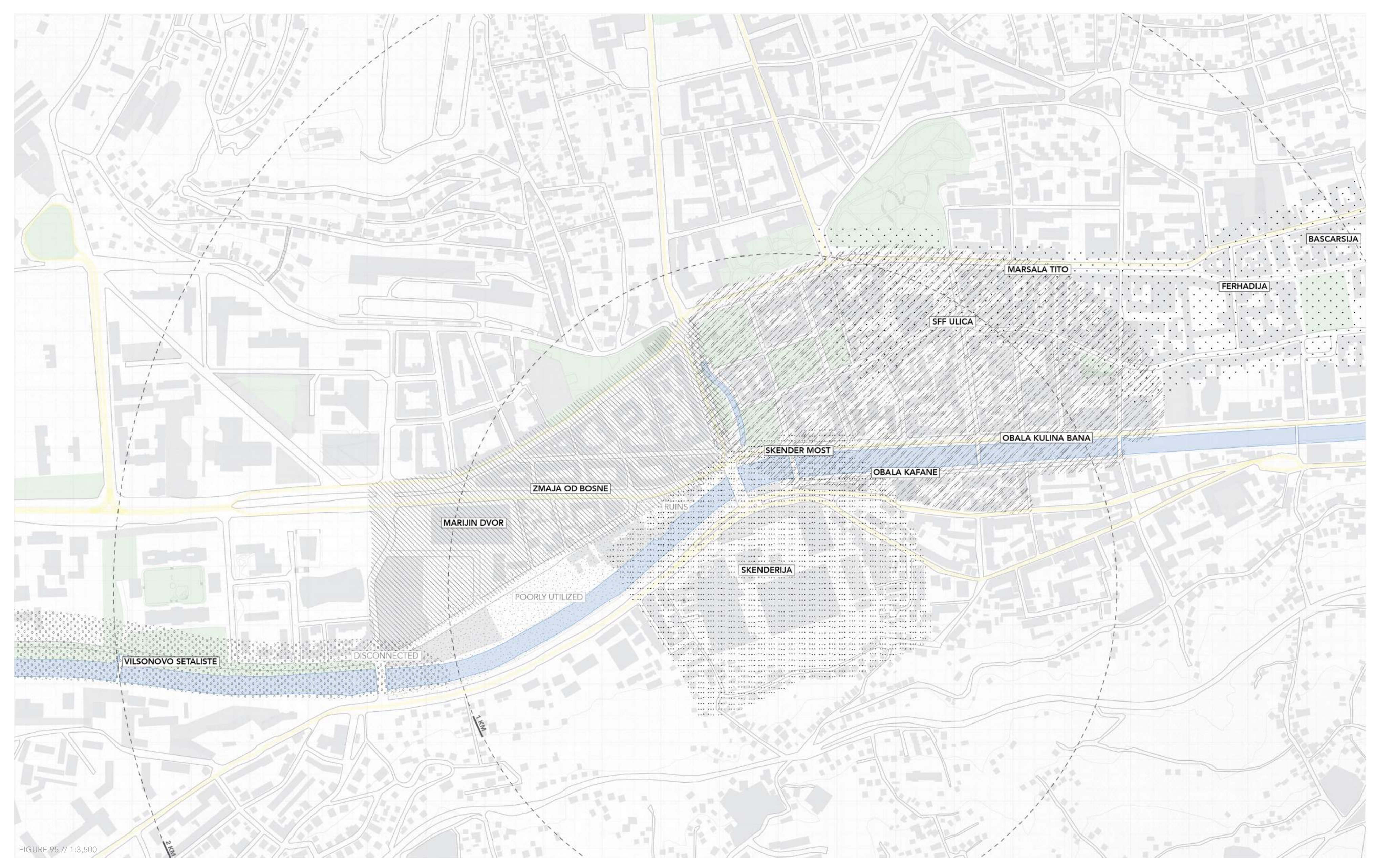




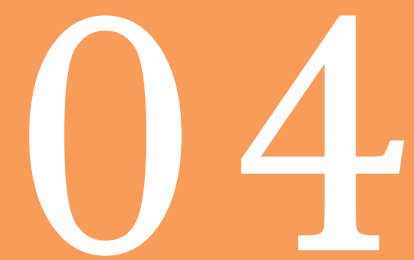

\section{// IMAGINATION OF A BUILDING}

Evolution of Skender-Bey

Tito's Skenderija

Olympic Symbolism 

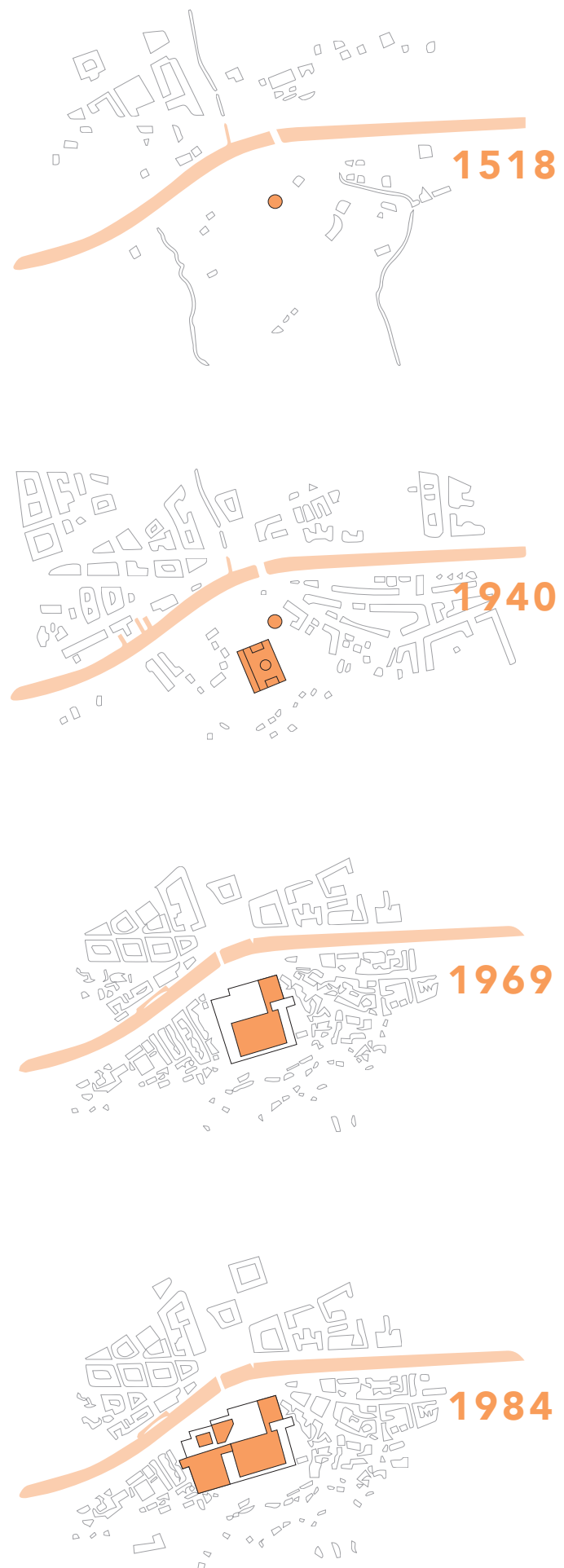

FIGURE 96 // 


\section{EVOLUTION OF SKENDER-BEY}

// IMAGINATION OF A BUILDING

During the Ottoman Empire, Iskender bey Paša Mihaloğlu, known as Skender-Paša, was the Bosnian sanjak-bey of the Bosnian Sanjak for the majority of 1478 to 1504 . Sanjaks were administrative divisions of the Ottoman Empire, and a sanjak-bey was the title given to a military or administrative commander for each district. In 1499, Skender-Paša built a tekke and imaret at the site of what is Skenderija today. Tekke, being the Turkish term for residence or lodge, and imaret, being one of the few names used to identify the public soup kitchens throughout the $14^{\text {th }}$ to $19^{\text {th }}$ centuries. These imarets gave food free of charge to the less fortunate; the concept was not invented by the Ottomans, but was appreciated and further developed under the Muslim religious teachings about charity. As tekkes and imarets were often part of a larger complex, Skender-Paša additionally built himself a caravansary with eleven shops on the grounds located on the other side of the Miljacka. He connected all these individual parts by a bridge, Skender Bridge (Figure 97-98). In 1518, Skender-Paša and his son, Mustafa beg Skenderepašić, lifted the first sub-location mosque in $\mathrm{BiH}$ beside his tekke. This is what began the development of Skender Bey's mahala. Its development extended past the mosque and the caravansary on the other side of the Miljacka, growing exponentially in both directions.

Skender-Paša's original complex was large enough that during the Austro-Hungarian rule it hosted Cirkus Platzon for the entertainment of Sarajevans, along with other activities of similar calibre. After the rulings of the Ottoman and the Austro-Hungarian Empires collapsed, Skender-Paša's grounds were repurposed into a soccer field and other sporting fields alike (Figure 99). In the 1960s when president Josip Broz Tito commissioned the creation of a new sports and multicultural complex, the existence of these fields made it easy to decide the location. As the city expansion went from 

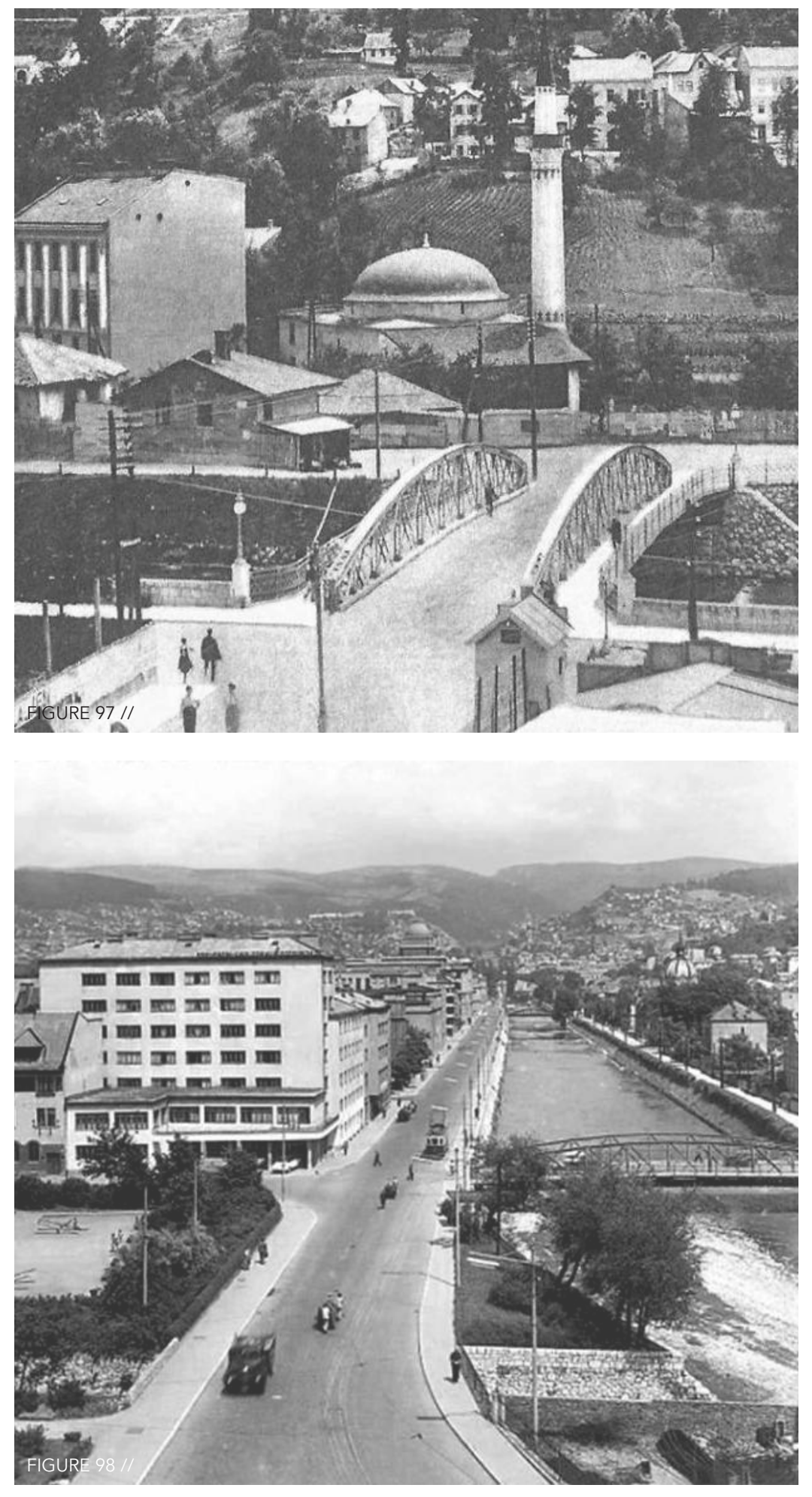


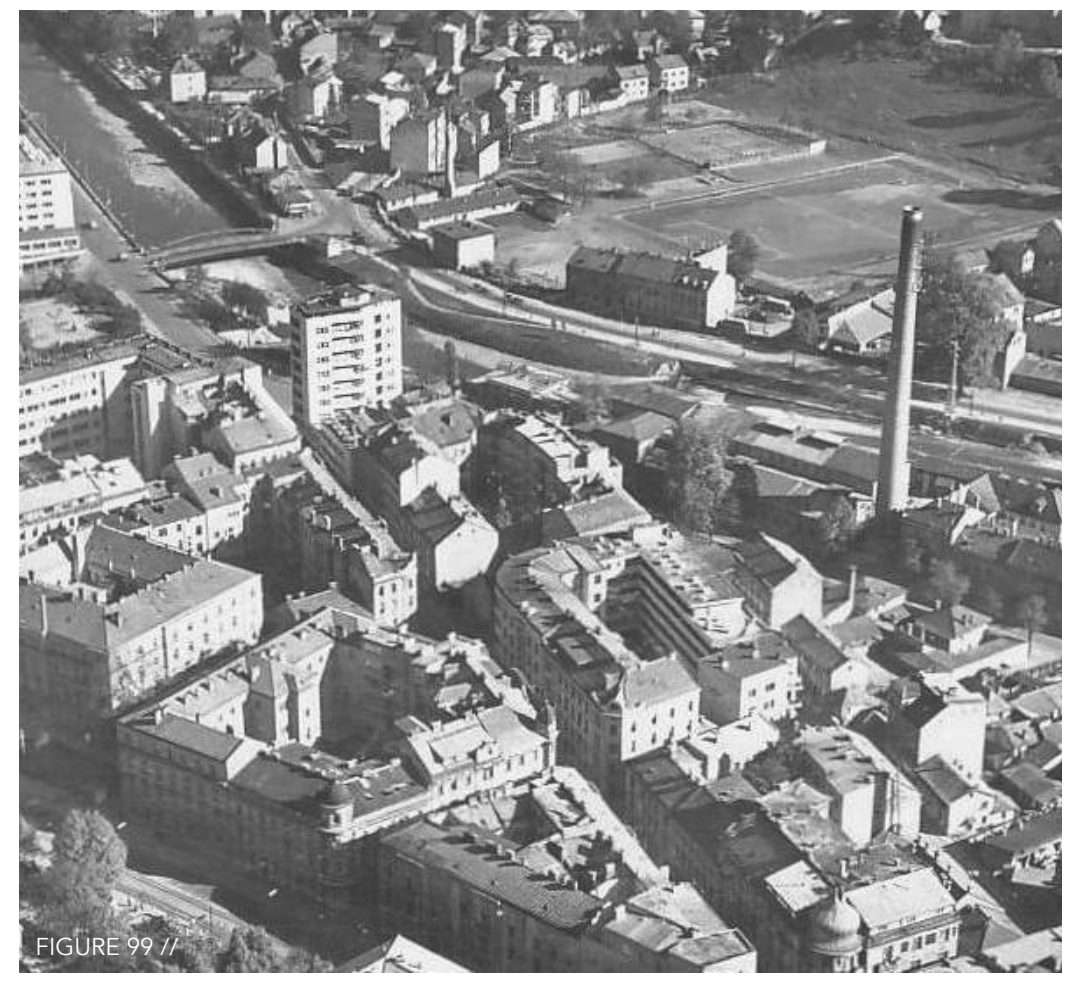

east to west in an almost chronological fashion through history, this allowed the opportunity for the first north-south axis development in the city. A large concrete vehicular bridge was built at its nodal point; this further emphasized Skenderija's newly appointed location. 


\section{TITO'S SKENDERIJA}

// IMAGINATION OF A BUILDING

The concept of these polyvalent institutions, encompassing culture, sport, leisure, commercial and entertainment all under one roof, was brought to life during the socialist period of Sarajevo's development. Designed for large gatherings, it promoted national unity and controlled the socio-cultural life. The undisputed, most representative of these institutions is Tito's Skenderija (Figure 100). Carried out in 1969, the exemplary architectural-spatial concept was realized in SFRY for the first time. The work of architects

Živorad Janković, Halid Muhasinović and Ognjen Malkin, Skenderija was ceremoniously opened by president Tito on November 29, 1969 (Figure 101) for the premier screening of 'The Battle of Neretva' bringing together two of Sarajevo's most prominent cultural faces, national unity and film. Skenderija even received a 'BORBA' award, the most prestigious architecture reward in Yugoslavia at the time, for the best architectural work in the entire country. Albeit achieving national recognition, the design of Skenderija was unique to the city itself and connected Sarajevans of all ages and ethnicities.

The concrete giant gave way to the city's socialist ideals, creating a new symbolism, meaning and rhythm of life for Sarajevans. Famous for their fairs, Skenderija allowed Sarajevo the exceptional ability to adapt to the differing programmatic requirements, within each of its interwoven spaces on site. For the duration of the 1970s, Skenderija hosted innumerable events such as, but not limited to, art exhibitions, ballets, circus performances, rock concerts, movie premieres, international festivals, orchestras, folk and pop culture entertainment, fashion shows, congresses, lectures, and international seminars (Figures 102-113). Skenderija's structure reaffirmed the successful organic integration of a city's social functions that need almost permanently flowing foot traffic from its visitors. 

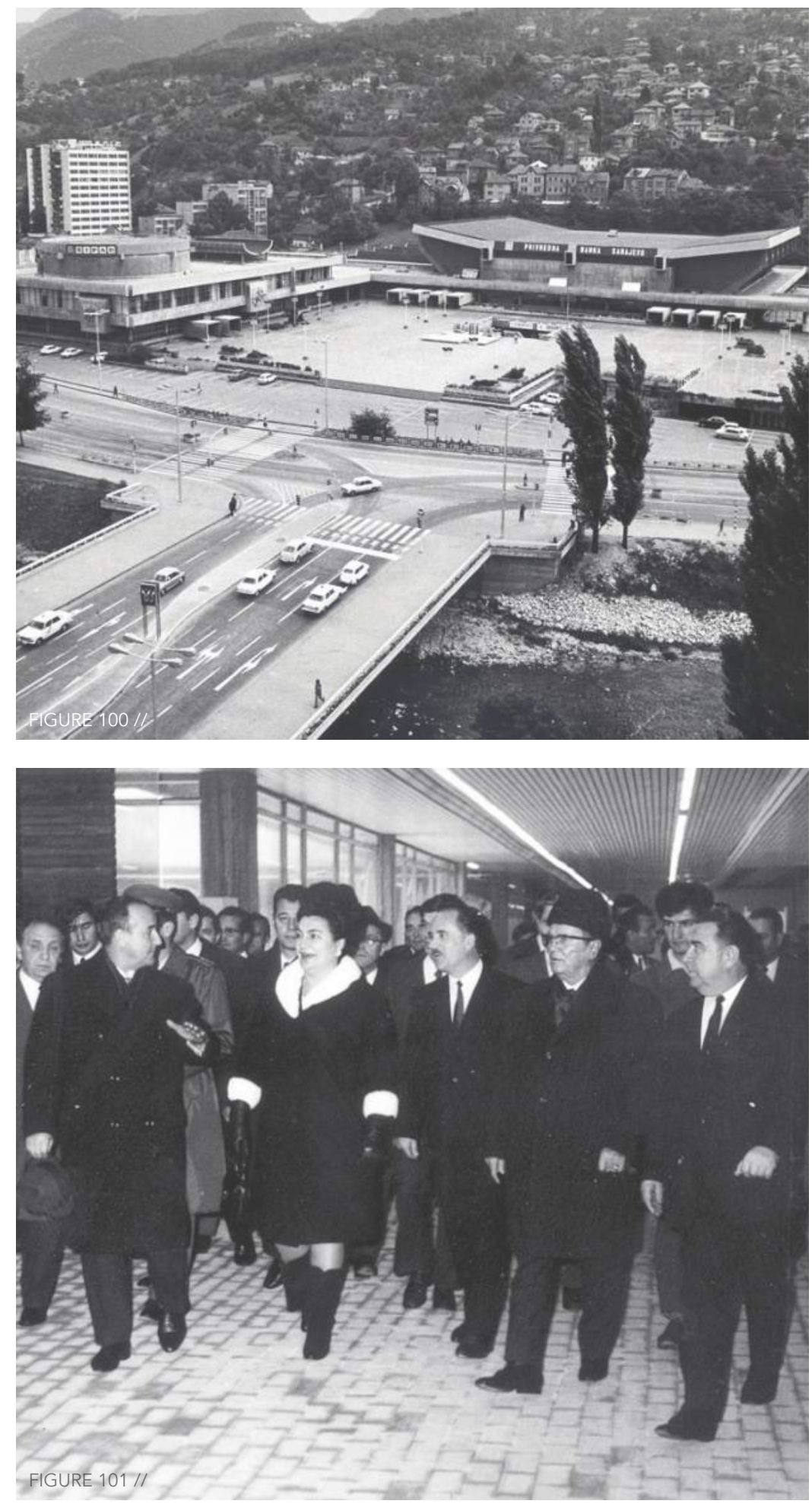

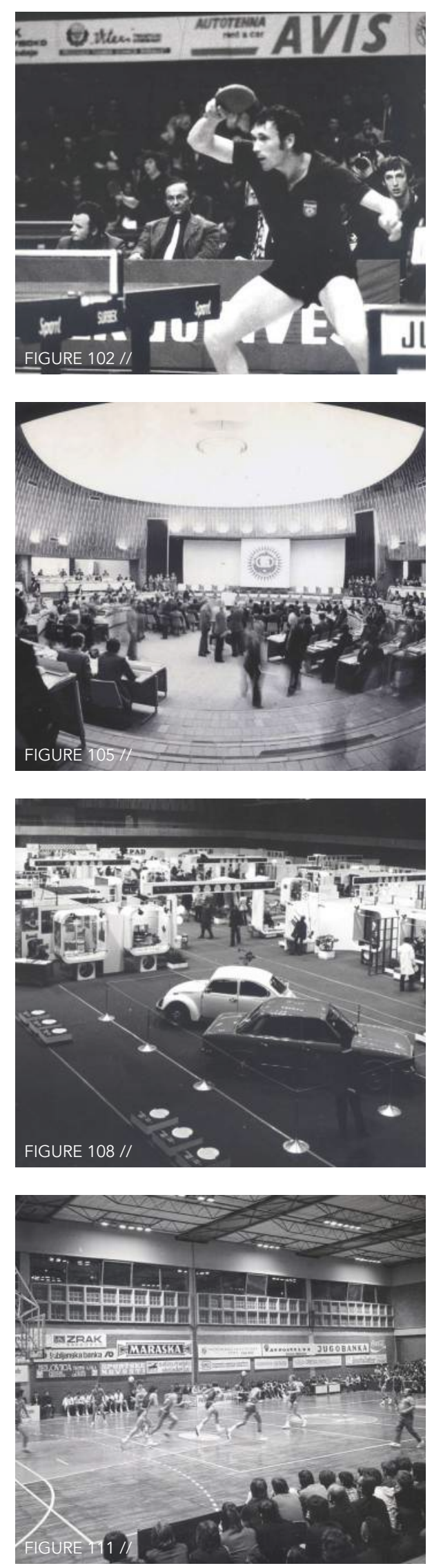
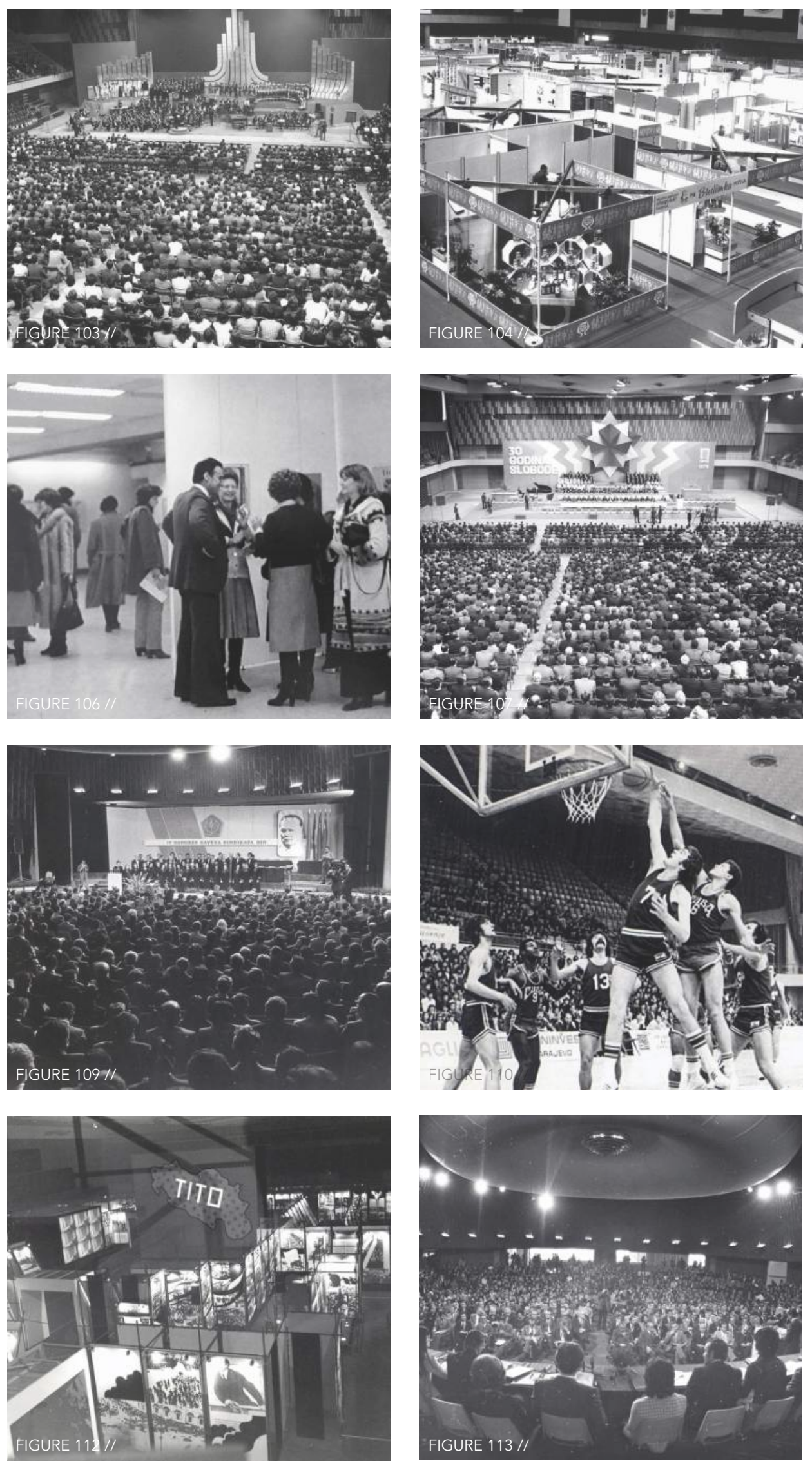

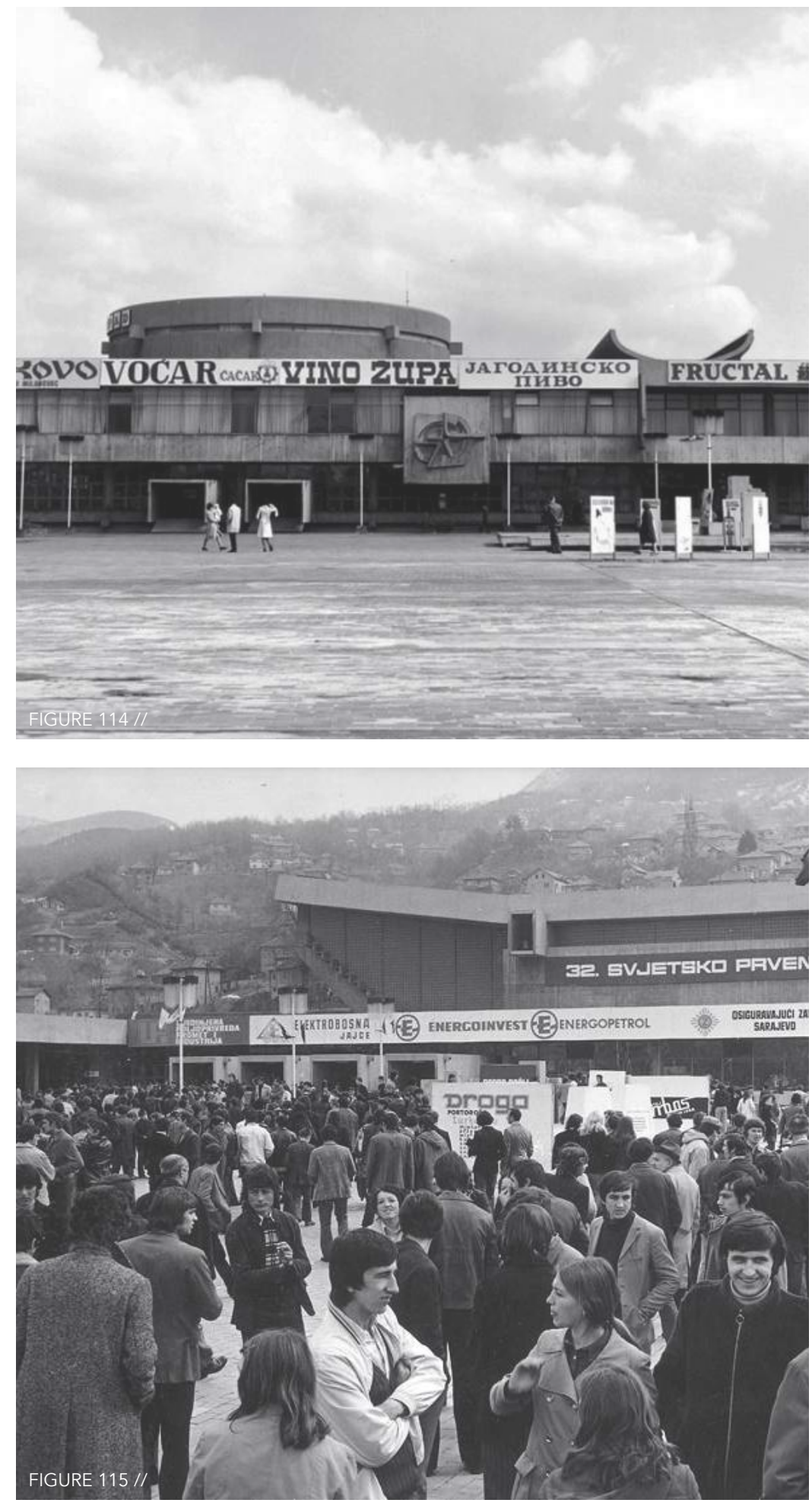


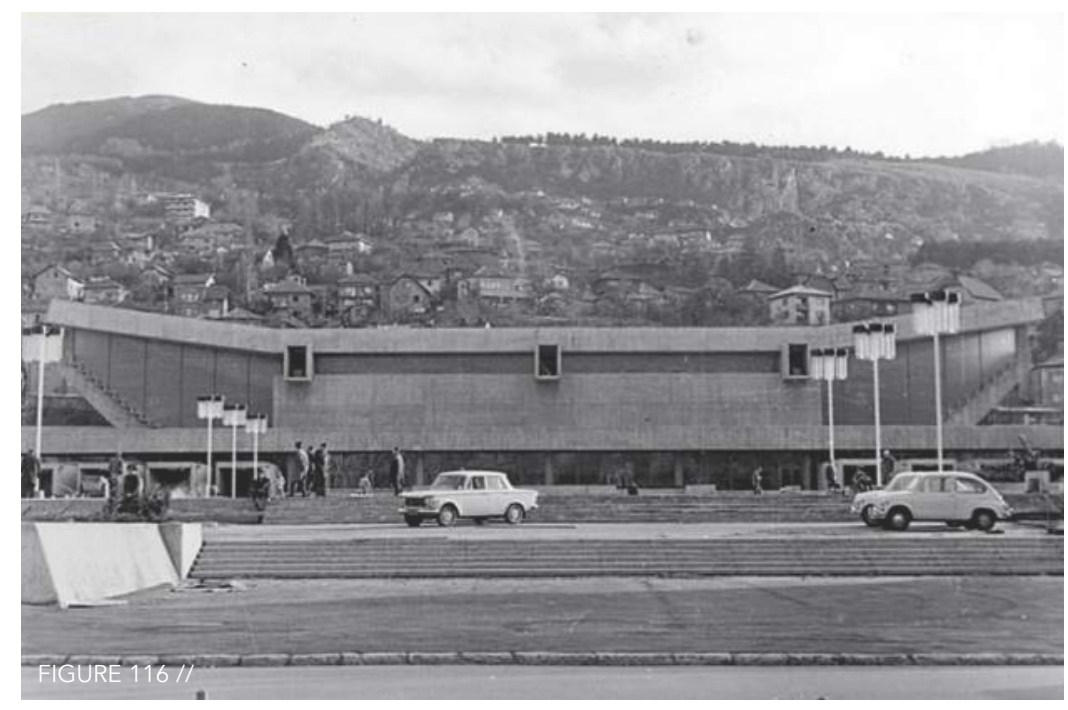

As a result of Skenderija's establishment, Sarajevo evolved into an economic city where high-quality forms of businesses and business people, from SFRY and abroad, would gather to exchange ideas and make connections. In addition, Skenderija's Dom Mladih [Youth House] was the place that shaped Sarajevo's youth, providing a place where they could be creative. Dom Mladih housed the incredibly popular 'Kaktus Disco Club', later symbolically renamed 'Vučko' after the 1984 Winter Olympics mascot. At the time, the Yugoslavian rock scene was unmistakeably the most iconic form of pop culture within the whole country, and Dom Mladih was its home base. Prominent Yugoslav rock stars that got their start there are notably Bijelo Dugme, Dino Merlin and Crvena Jabuka. In 1979, when Sarajevo was selected to host the 1984 Winter Olympic Games, the decision to expand the complex for the accommodation of a citywide event came as easily as Skenderija's conception itself. 


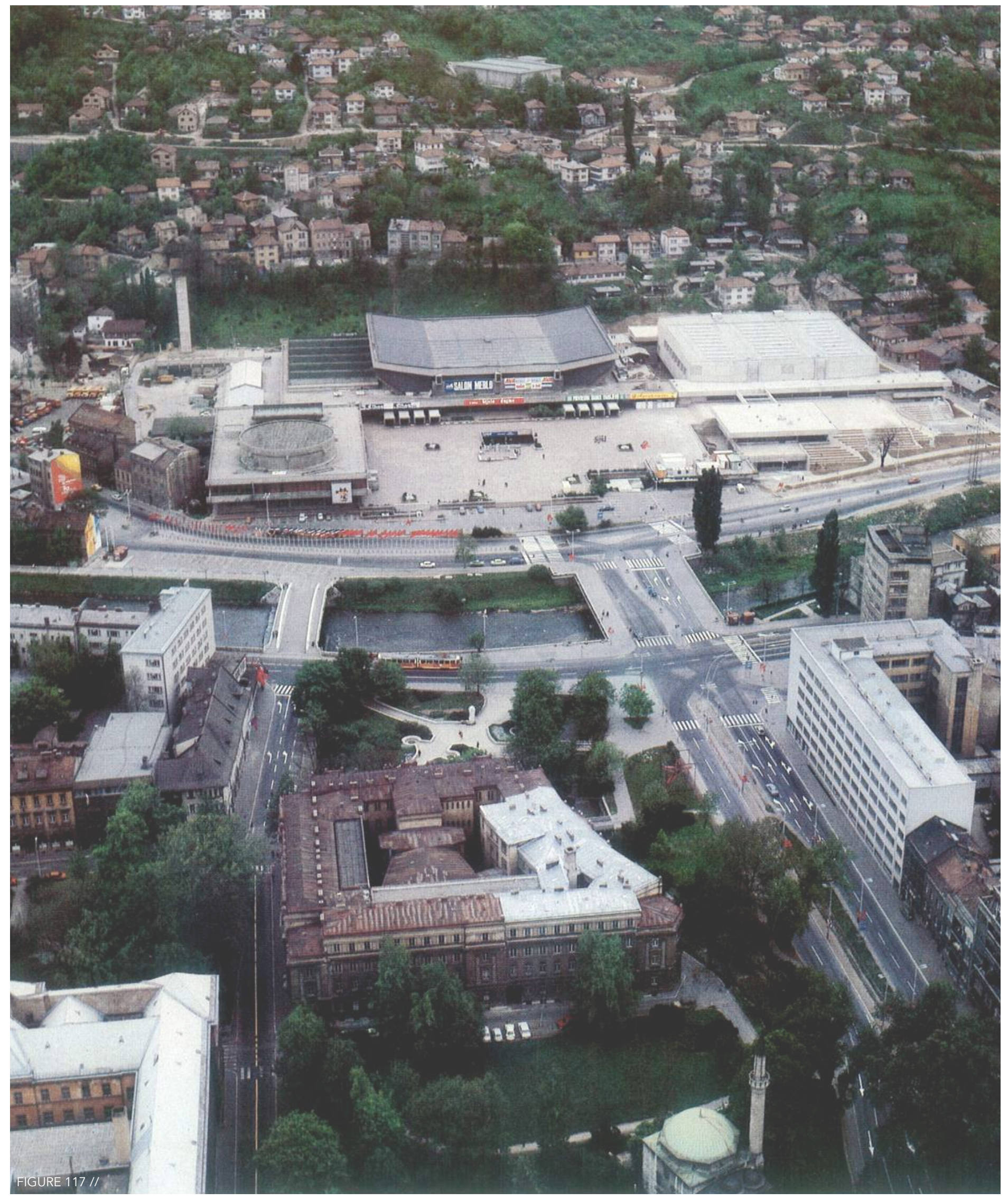




\section{OLYMPIC SYMBOLISM}

// IMAGINATION OF A BUILDING

Prior to the site's involvement in the Olympic games, Skenderija significantly facilitated the development of the city's sporting life in mass and quality. It was where Yugoslav, European and even International level clubs worked and competed. In its first few years, Skenderija hosted the Yugoslav Championship in table tennis, the European Basketball Champions Cup, the Balkan Women's Volleyball Championships, the International Handball Championship and the qualification for the World Basketball Championships. There were also numerous professional boxing giant matches and professional basketball Club Bosna games.

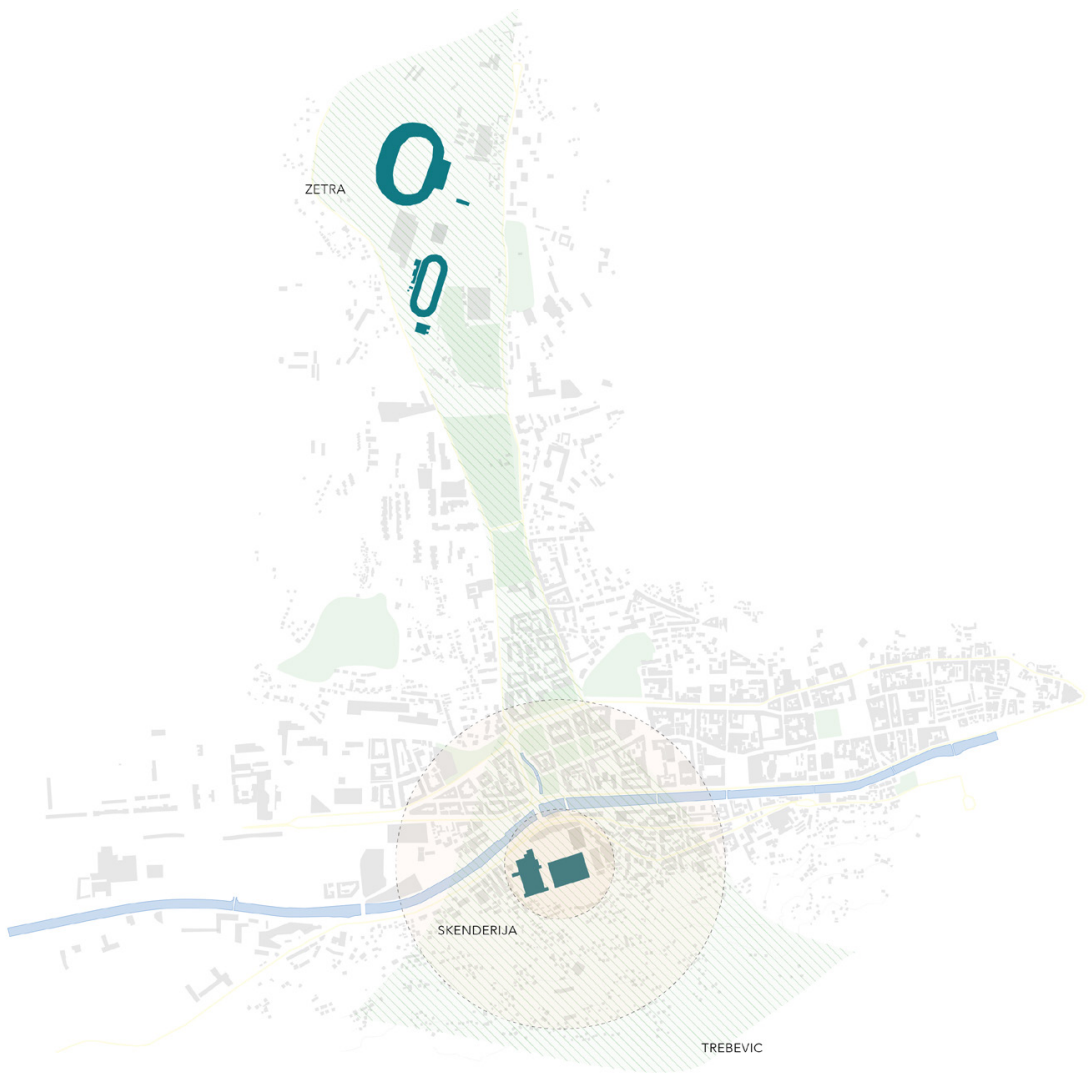

FIGURE $118 / /$ 


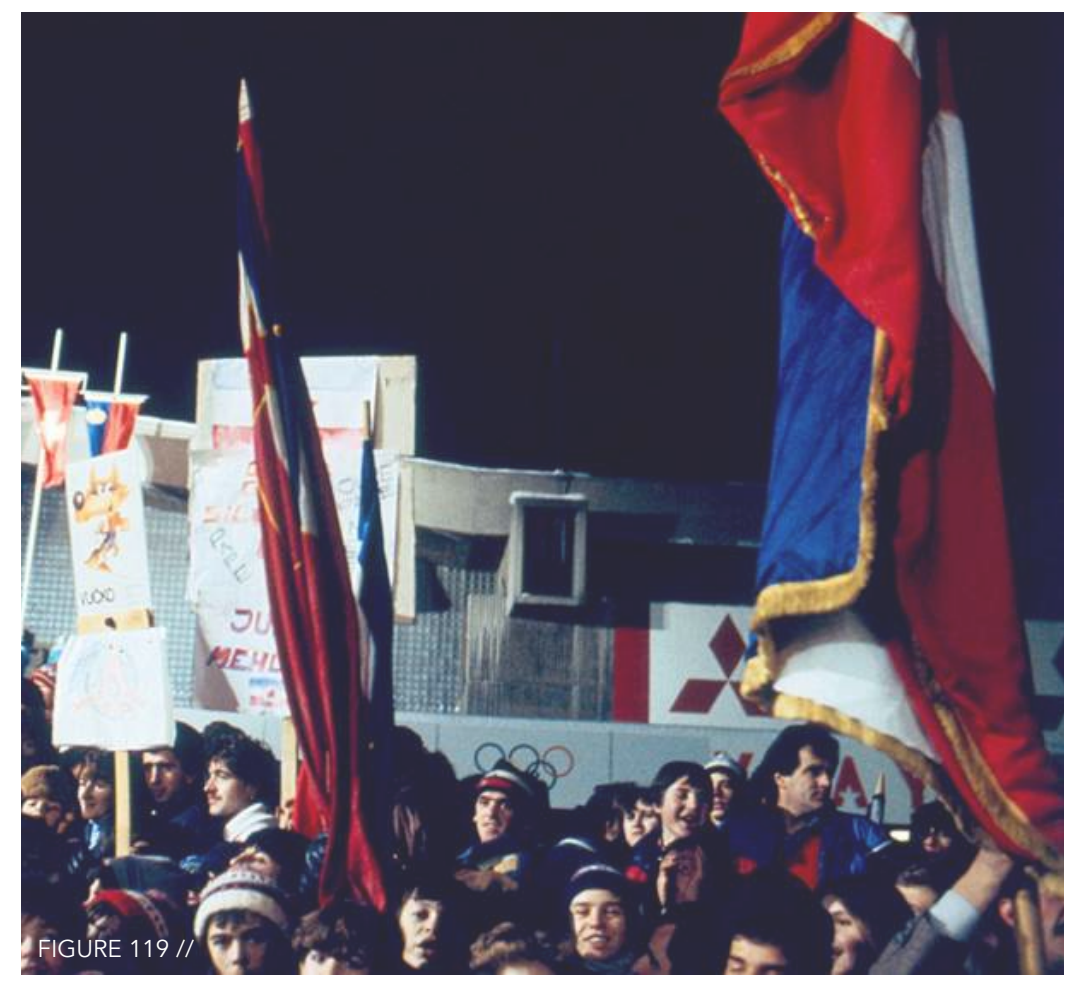

When the focus shifted to the 1984 Winter Olympic games, Sarajevo strategically utilized Skenderija's nodal position in the urban organization of the city. With the historic district to its east, and the socialist housing boom built to its west; the overlooked north-south axis, as earlier described, was proposed as a green passage and nicknamed 'ZeTra', or 'zelena transverzala', meaning green transversal (Figure 118). This established Olympic corridor intended to link the newly built Zetra Hall to Trebević Mountain, with a new urban network of green spaces and Skenderija complex at its core. The already nodal position of Skenderija was reinforced in both the activities and images of the Olympic games. During the festivities, Skenderija's facilities were used in a considerable number of ways. Its main arena, Mirza Delibašić Dvorana, held hockey trainings; Ledena Dvorana was for figure skating; all press conferences and radio interviews were done in Dom Mladih; and medal ceremonies took place on the plateau (Figures 119-121). 

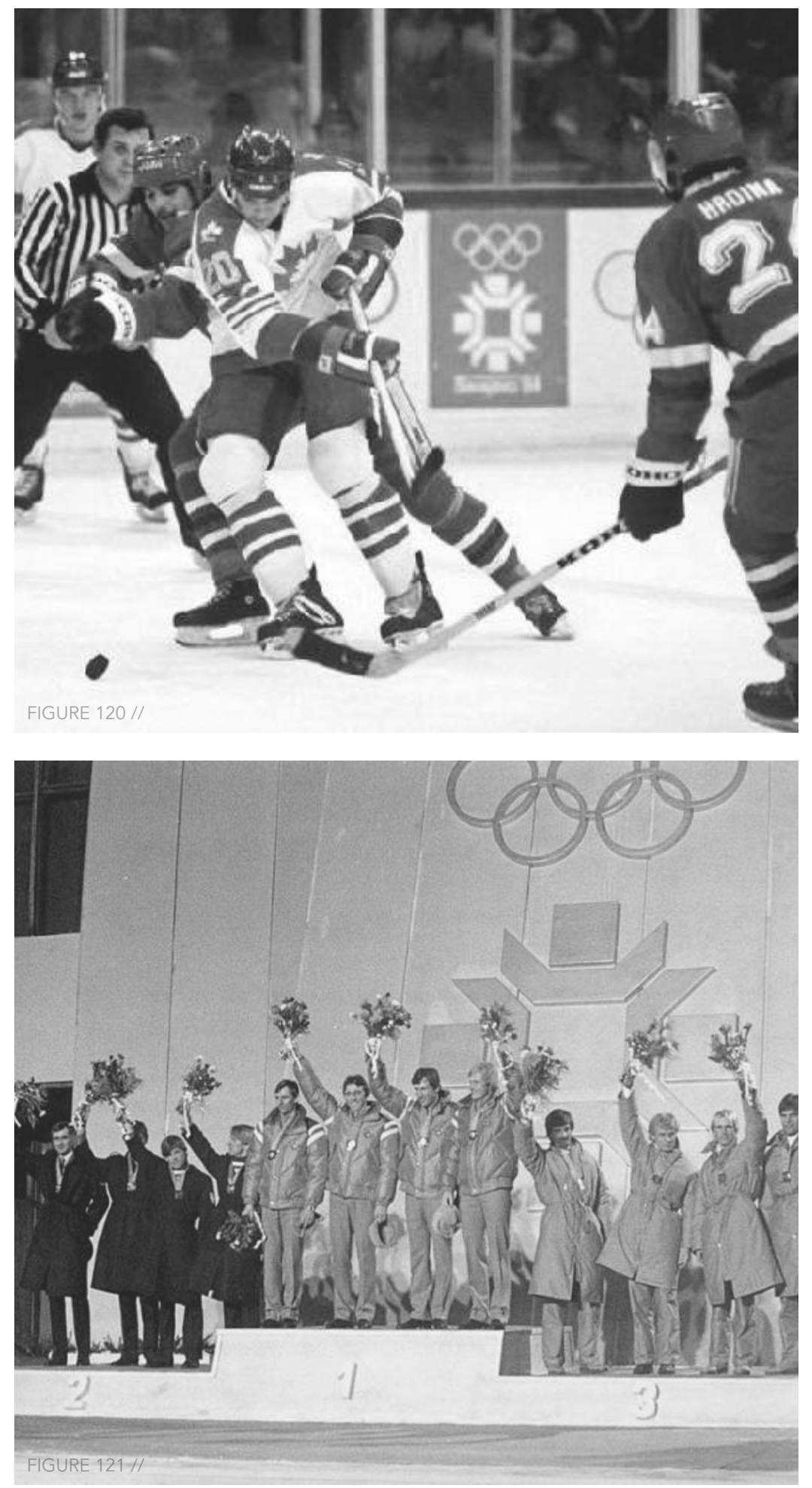


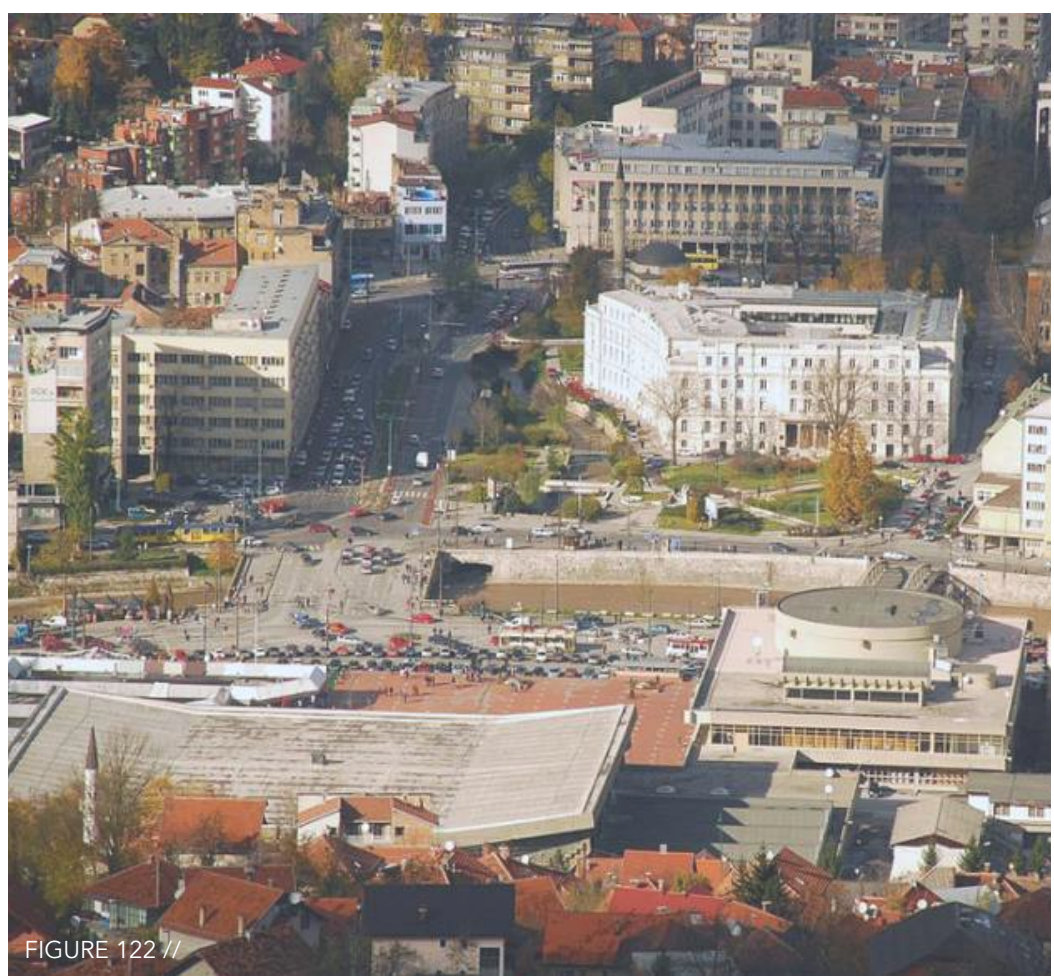

Its position at the crossing of the city's two axes - moving from east to west along the river and from north to south along valley to mountaintop - made Skenderija a valuable and vulnerable target during the war. Its proximity to the frontline during the siege, in addition to its visibility from Trebević Mountain where the BSA set up sniper and shelling posts (Figure 123), made Skenderija an incredibly dangerous location for Sarajevans. In 1992, as an act of memoricide conducted by the BSA, Skenderija's Dom Mladih was shelled and burned from the inside out leaving the city with just its shelled exterior. As the rest of the complex sustained only minor damage, the concrete giant inherited yet another layer of life operating as the UN's wartime depot for humanitarian aid (Figures 124-125). 

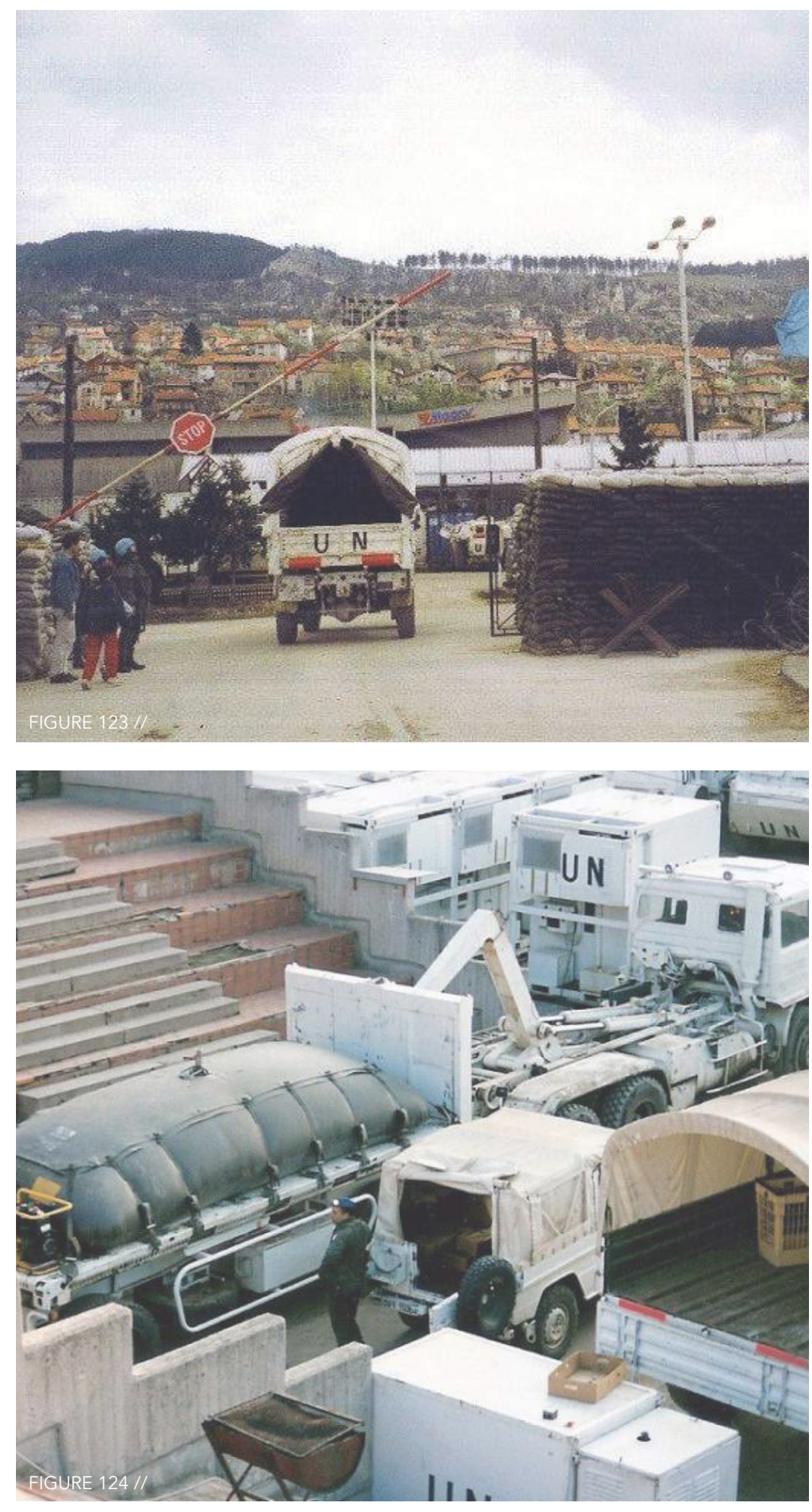


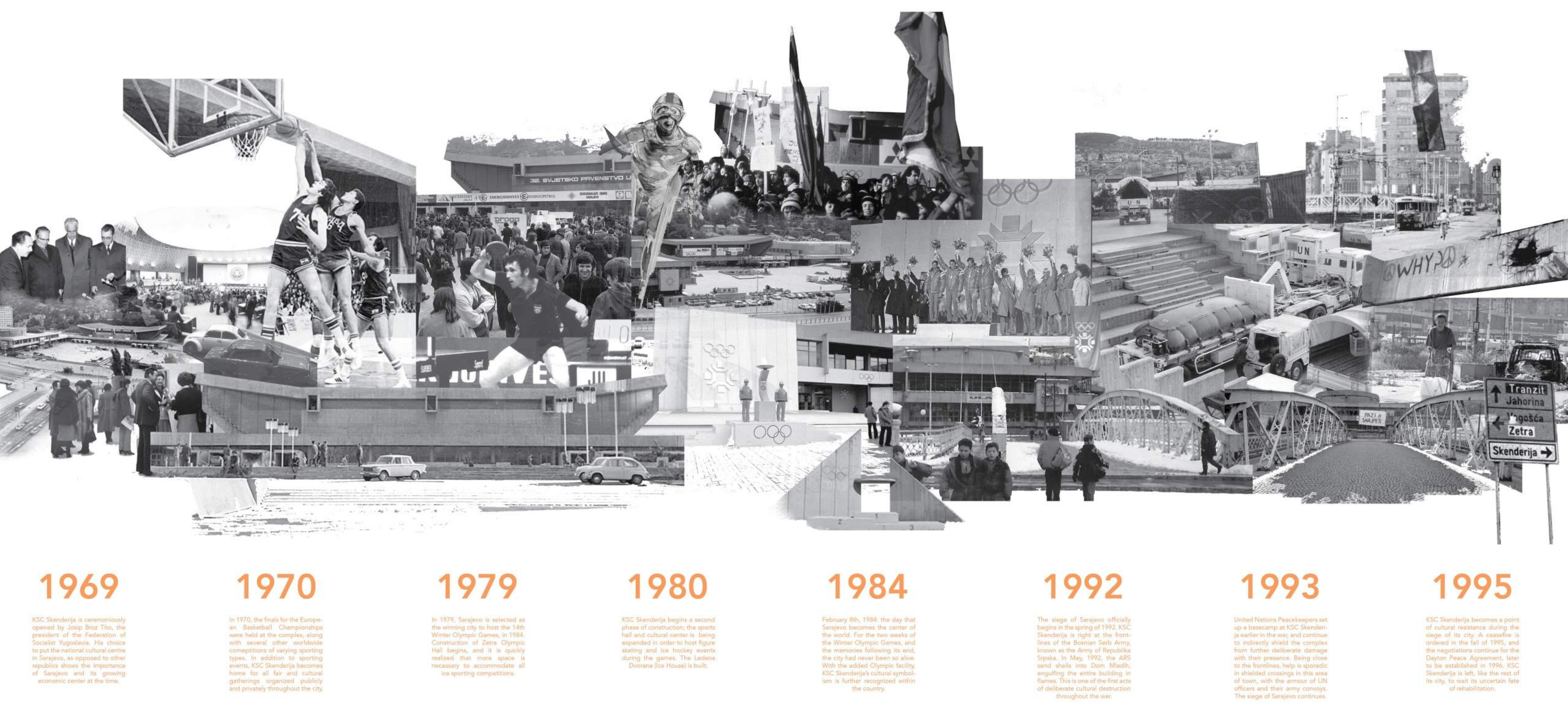




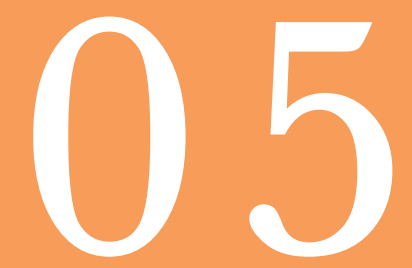

\section{// CULTURAL REINTEGRATION}

Site Impressions

Skenderija Reactivated

Skenderija Takes Centre Stage 


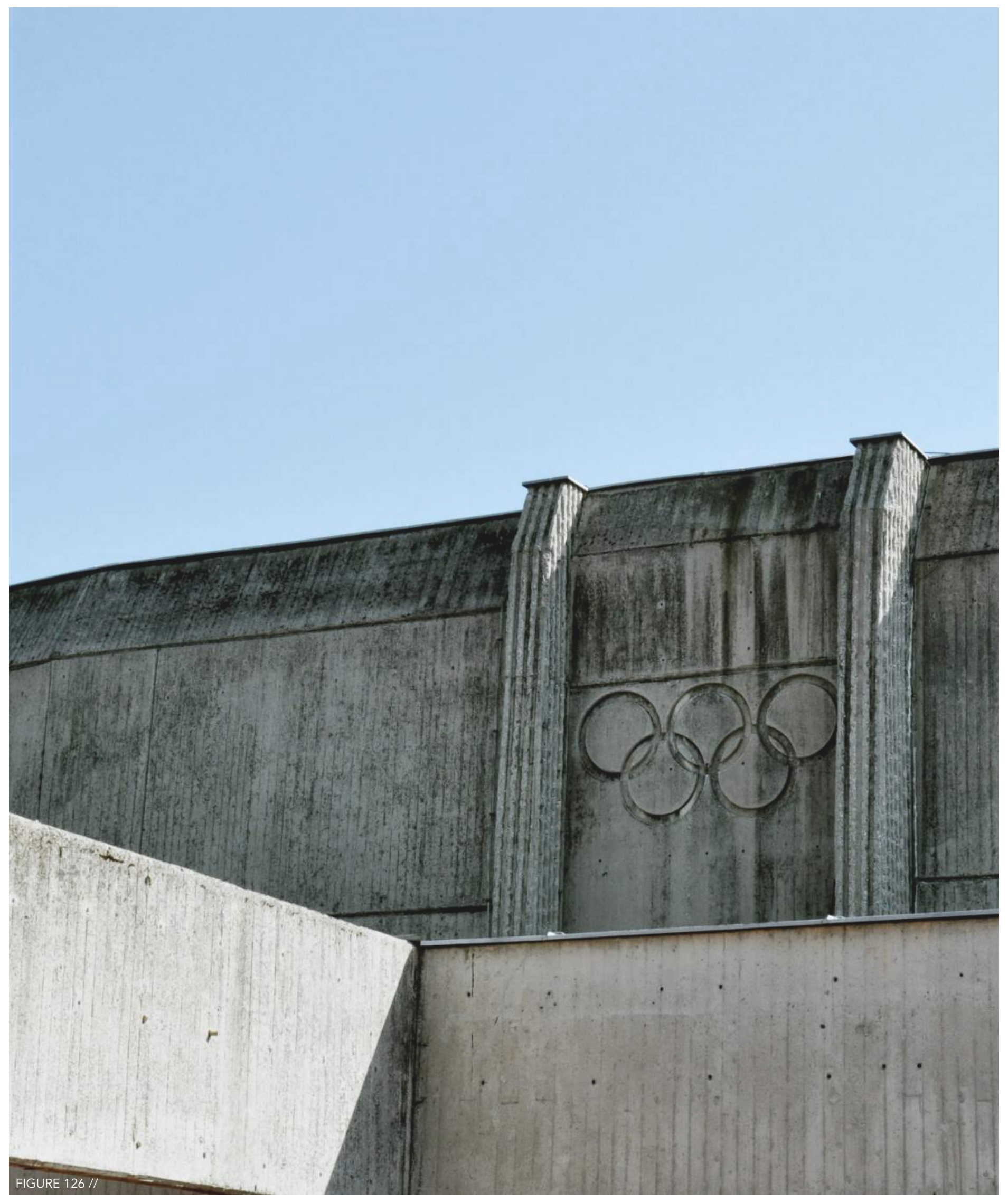




\section{SITE IMPRESSIONS}

\section{// CONDITIONAL ASSESSMENT}

Sarajevo's initial reconstruction efforts were allocated for the reconstruction of roads, bridges, and schools, so as the years passed after the war, Skenderija's entire complex fell into disrepair. Along with the development of the new socio-political world of consumerism, the new buildings erected in the city were of large-scale commercial typology, causing the shops beneath Skenderija's plateau to fade into a ghost town. This further threw Skenderija, once the main gathering space in the city, into a state of oblivion.

It wasn't until 2000 that Sarajevo decided it was time to renovate the complex in order to help with BiH's economy and trades. Financed by several independent companies and private investors, Skenderija began its reconstruction period under the ownership of these private bodies. Dom Mladih [Youth House] reopened in 2007, resuming its function as a cultural, sports, and events venue for Sarajevo's youth, with a portion of the building now housing the Ars Aevi Museum of Contemporary Art. Skenderija's main arena, Mirza Delibašić Dvorana, continued its function as Bosnia's professional basketball court, and Ledena Dvorana [Ice House] held administrative offices and gave an additional auditorium space. When Ledena Dvorana's roof collapsed under heavy snow load in 2012, the building became a literal shell of its past where it continues to stand roofless alongside its surrounding landscape. Although Dom Mladih still holds space for numerous opportunities of use, the foot traffic has only been sustained to the eastern part of the complex where visitors come and go for each event. People do not gather there or cross through the complex, which is what Skenderija previously thrived upon. In an effort to revive the social life of the complex, a façade face-lift was applied to Skenderija's main hall, Mirza Delibašić Dvorana, by painting its bare concrete exterior. This action caused immediate uproar in Sarajevo's architecture and design community. 

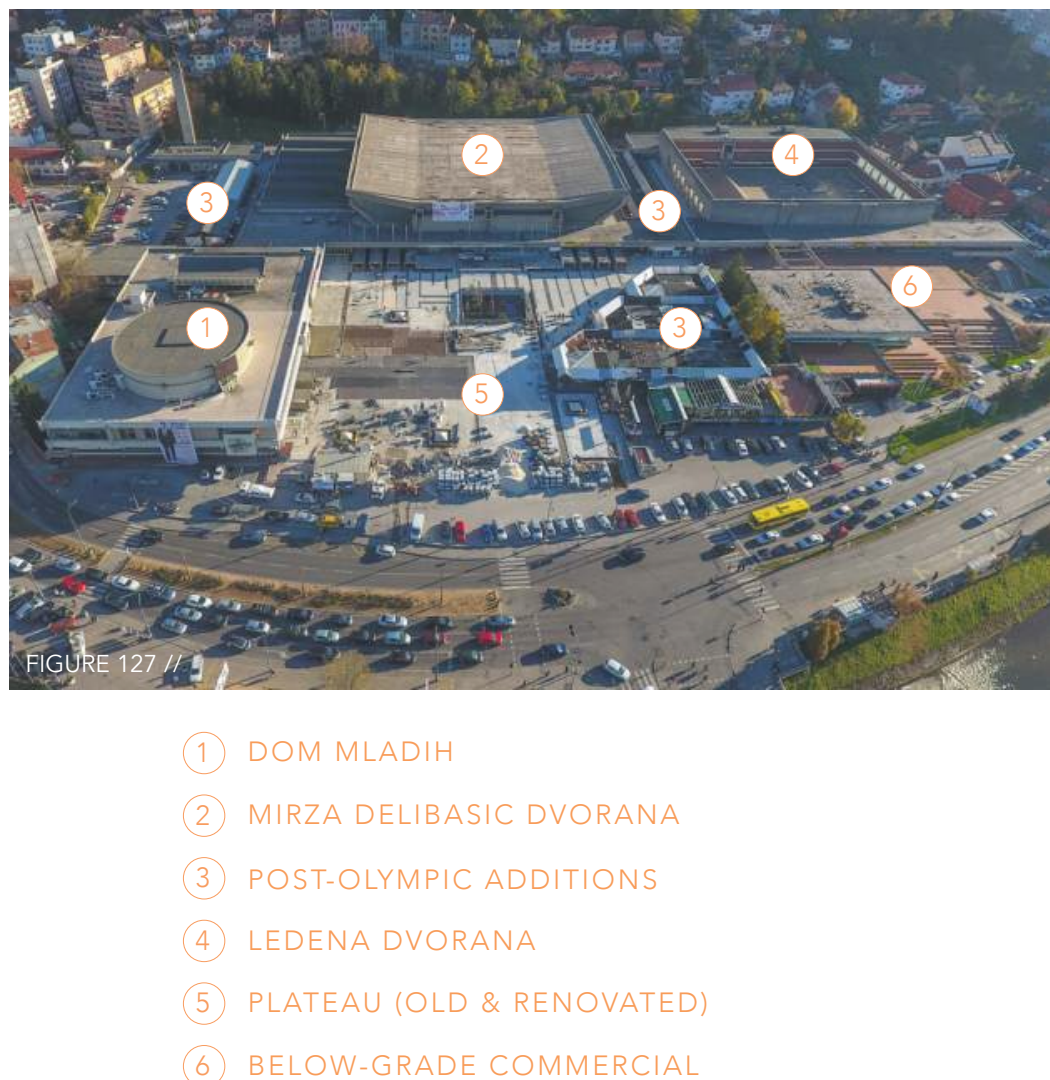

All collectively agreed that this action violated one of the basic stylistic characteristics of the building, destroying the aesthetics originally intended. Further to this, renovations on Skenderija's plateau began in the summer of 2016. Torn and broken red terracotta tiles were replaced with new grey ones, and the 1984 Sarajevo Winter Olympics logo had symbolically been tiled at its core, taking centre stage.

Despite the change of red terracotta significantly altering the appearance of the originally conceptualized plateau, it is immediately richer in functionality. With the project's completion the plateau's pedestrian traffic has increased, but its boundary line has only slightly spread across the new area. As the renovation only extended as far as Mirza Delibašić Dvorana and didn't cover the plateau in front of the roofless Ledena Dvorana, the complex is left with an entirely dead end. 

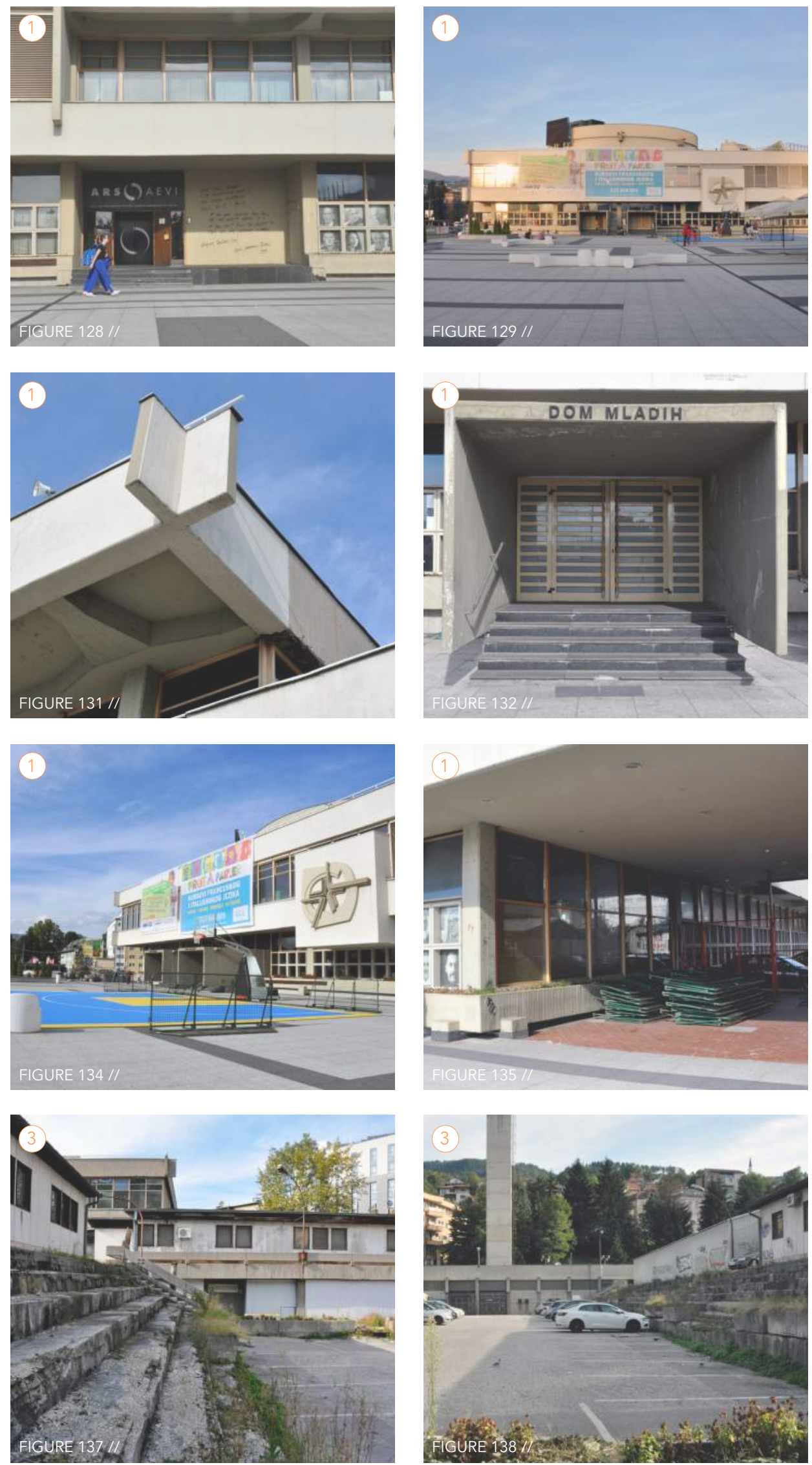
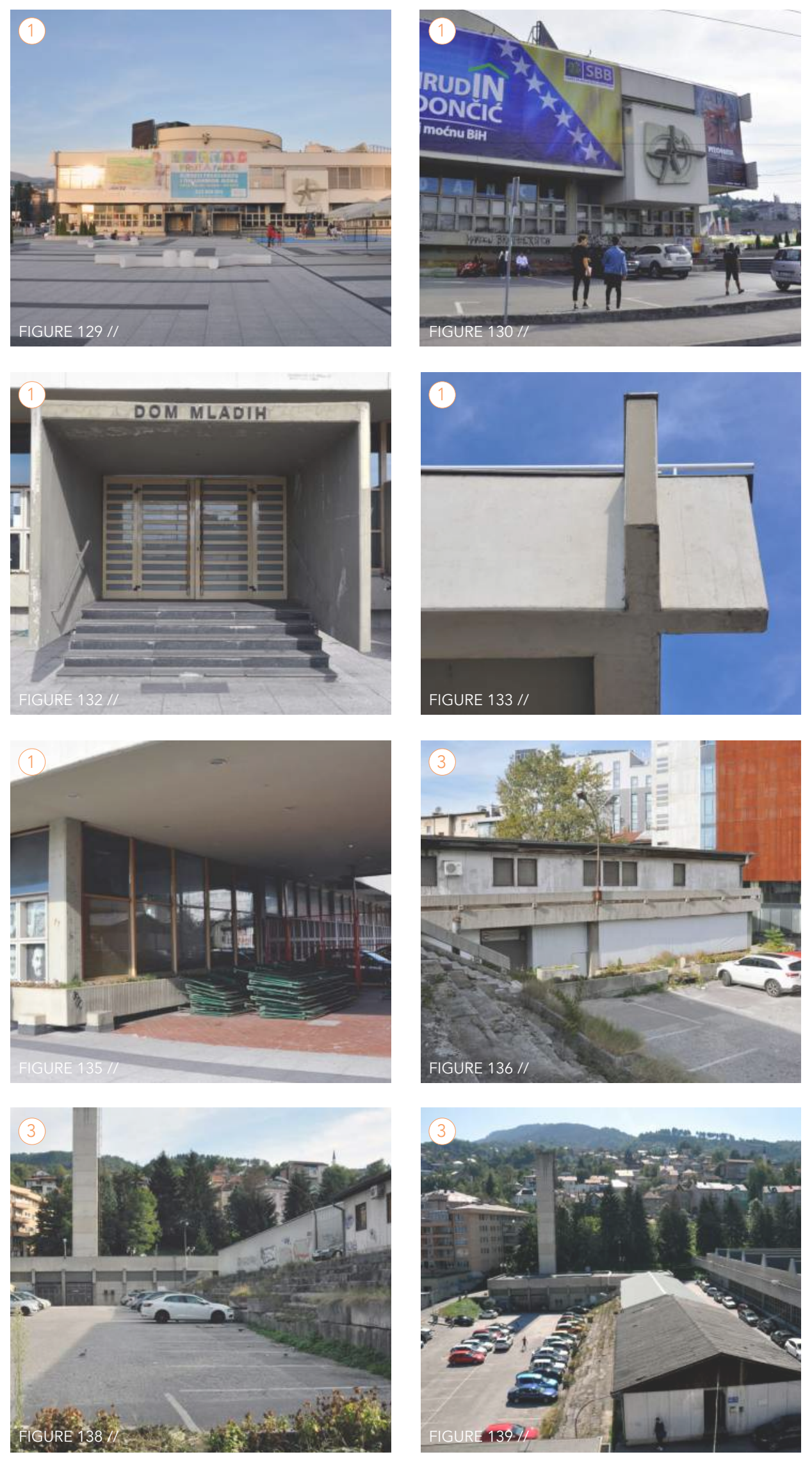

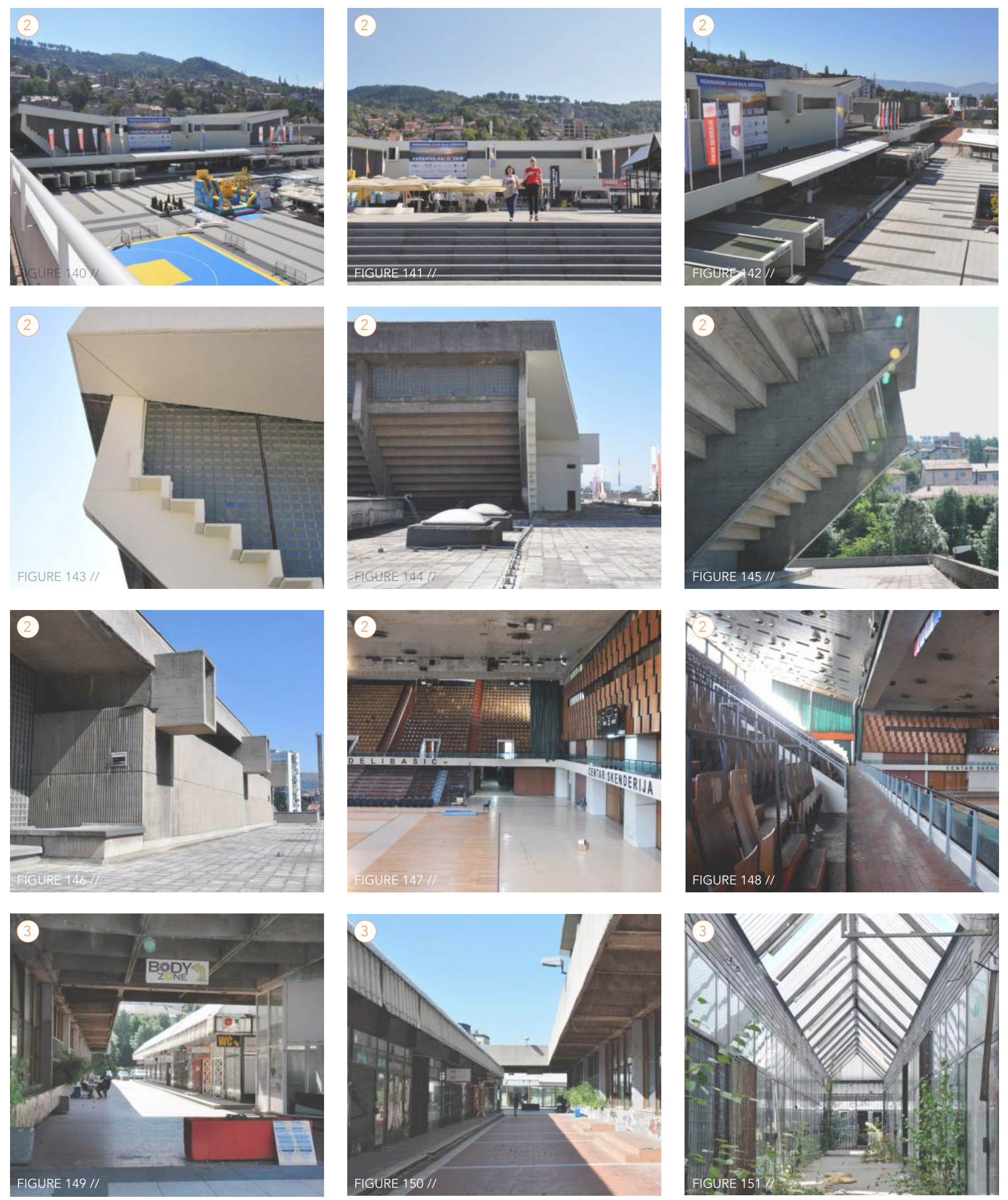

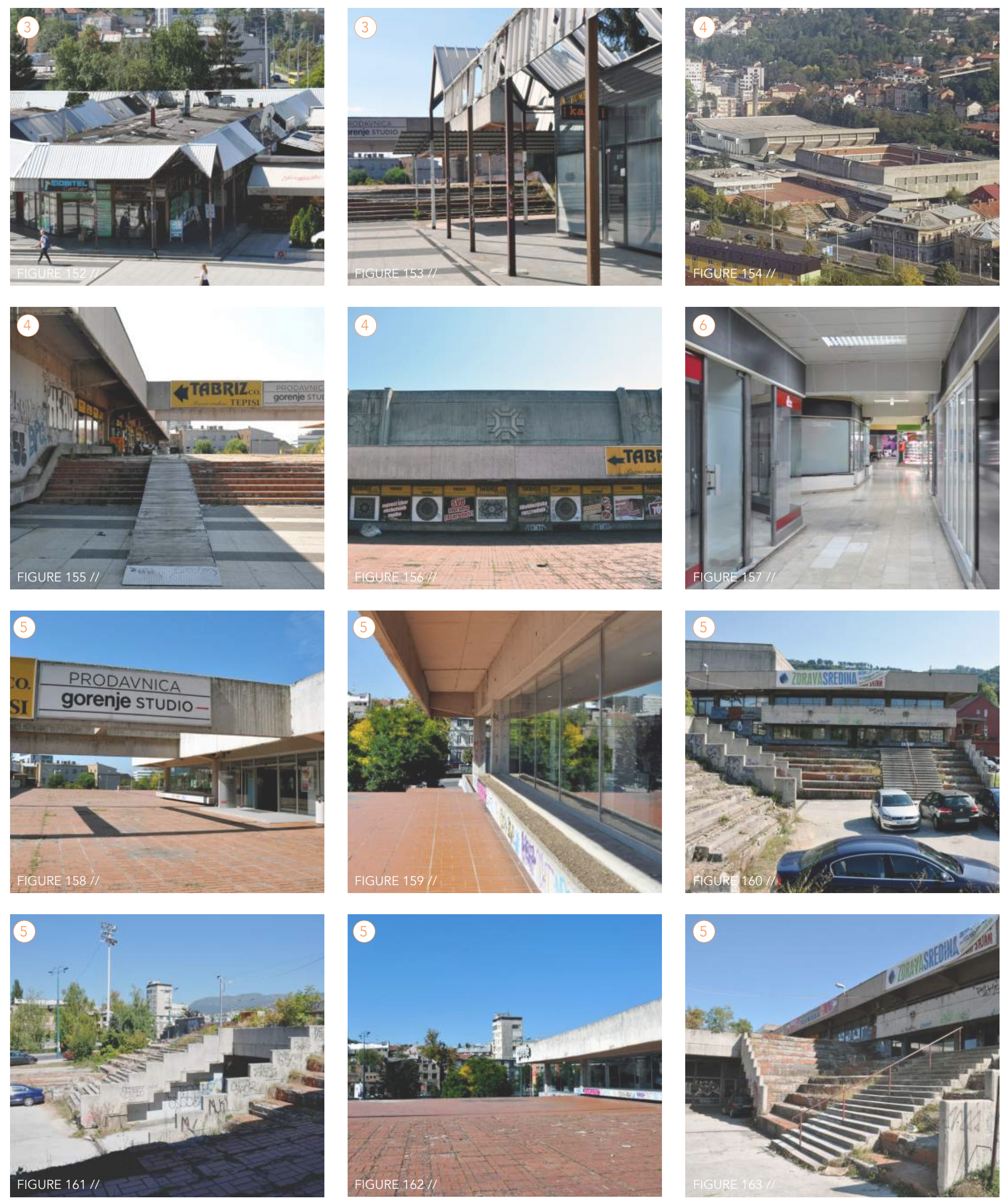
70, 000 sqm whole complex

10, 000 sqm plateau area

274 commercial shops below grade

$65 \%$ available for rent/unoccupied

10, 900 sqm Mirza Delibasic Dvorana

15, 000 maximum capacity

D1 sport/cultural/entertainment auditorium

$\mathbf{8 0 0}$ Dl auditorium capacity

D283 martial arts \& gymnastics auditorium

7, 000 sqm Dom Mladih [Youth House]

2, 000 upper Hall (standing) guest capacity

$\mathbf{8 0 0}$ upper Hall (sitting) guest capacity

600 amphitheatre (standing) guest capacity

300 amphitheatre (sitting) guest capacity

1992 burnt down

2007 renovated \& reopened

3, 226 sqm Ledena Dvorana [Ice House]

2012 roof collapsed

2016 plateau paving renovation 


\section{SITE IMPRESSIONS}

// CONTEXTUAL ASSESSMENT

The following mapping exercises illustrate Skenderija's location within the context of Sarajevo. The city's organization has been a product of its historic development over many centuries, which has also determined Skenderija's monumental position. With old town cafés and restaurants dominating the eastern side of the city, the socialist residential expansion dominating the west, and the Austro-Hungarian administrative district at its core, Skenderija is properly surrounded by all necessary socio-cultural pieces that make an effective urban site within a city.

Through the reuse of Ledena Dvorana's derelict shell and the revitalization of Skenderija's plateau, this thesis is well equipped to reintegrate into its socio-cultural landscape. 


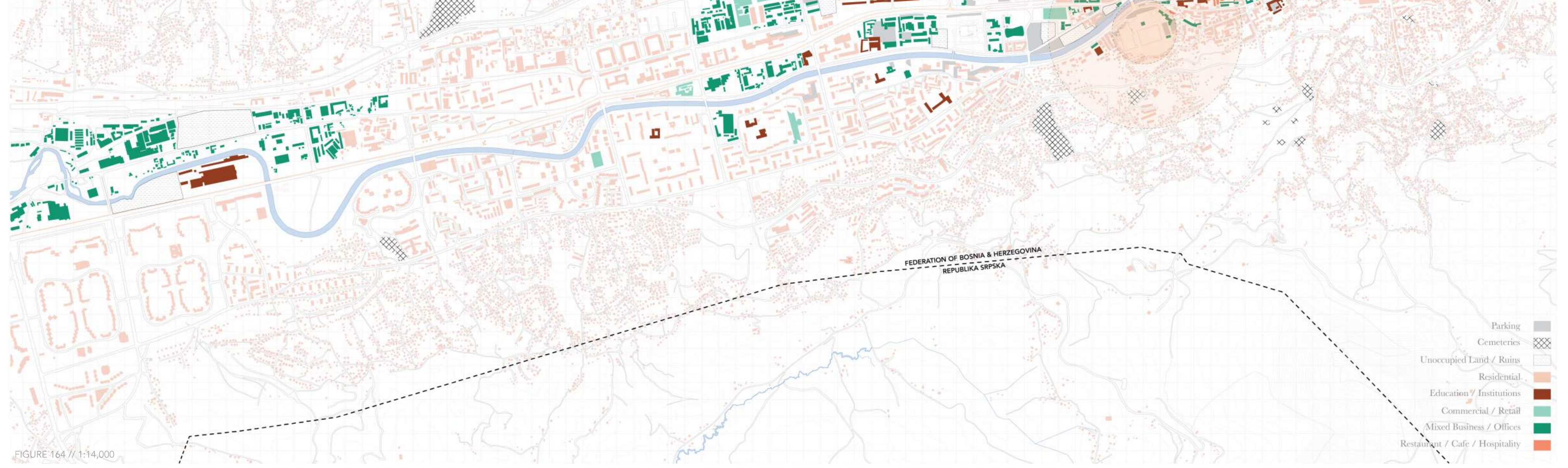


0

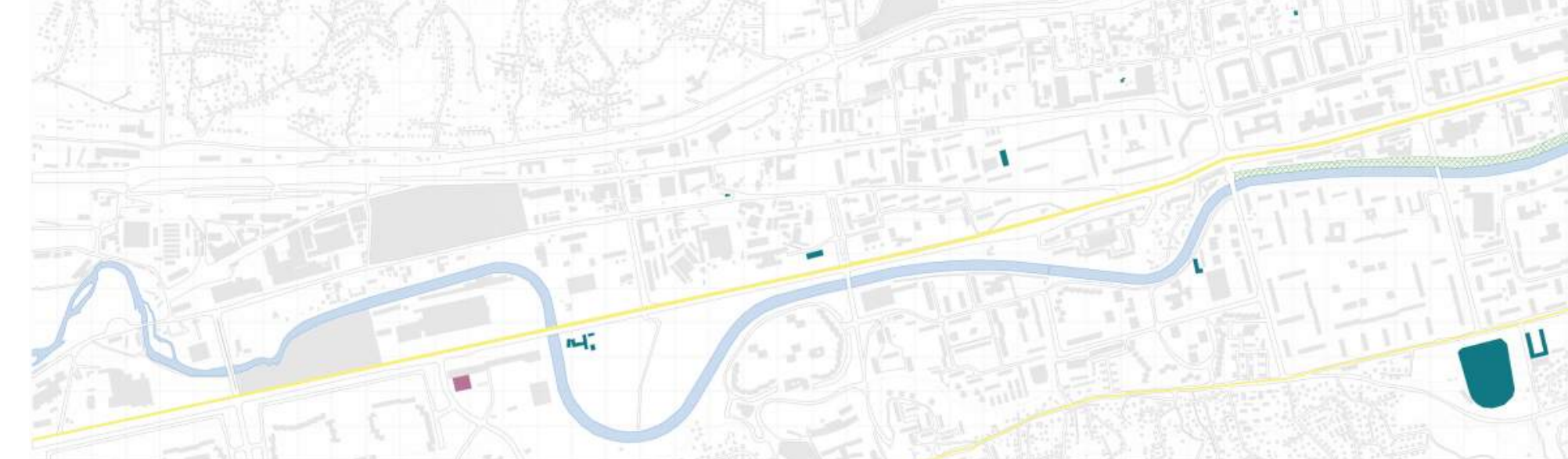




\section{SKENDERIJA REACTIVATED}

// CULTURAL REINTEGRATION

Built where two valleys meet, Skenderija's location is the connection point between two historic city developments. This position is unrepeatable in Sarajevo's city structure. Its strength goes beyond the issue of centrality, "it is the place where the geography of the city was predetermined for monumentality." Despite this favorable setting, over the years Skenderija's complex has detached itself from the rhythms and routines of everyday social life. It lies directly at the intersection from Vilsonovo Šetalište to Ferhadija Street, the two main pedestrian walkways in the city, passing right through Sarajevo's cultural and arts district. By acknowledging Sarajevo's rich walking culture and artistic capabilities, determined through site analysis, this thesis addresses a series of overlooked disconnections, bridging the gaps between Sarajevo's prominent societal activities.

The goal is to bring people back to Skenderija. Sarajevans are all in one way or another tied to the complex, and the relationship must be restored. A newly renovated space is not the feature of reconstruction that determines its success within a city; it is the cultural nuances that energize its urban life. While early reconstruction of Sarajevo understandably prioritized buildings of basic everyday necessity, the exclusion of culture, arts and social spaces, "denies one of the major pillars that supports humanity. Humans depend on culture, and cities, as human environments, even more so."2 Established as the highest evidence of modernist architecture during the socialist Yugoslav era, Skenderija needs to demonstrate an appropriate significance to the city once again. A facility for all Sarajevans and the whole country, it has always been a symbol of the city and the state. "Skenderija cannot live without people; she can only survive if she is filled with citizens." ${ }^{33}$ Therefore, all

individual parts that make up the whole complex must work together to propagate its value as a multifunctional spatial unit. 


\section{When the Italian}

architect Renzo Piano came to Sarajevo, I had the honour to show him the city and I remember, before Skenderija he stopped and said: 'Che bella brutta!' 
Architecturally, Skenderija is a softened version of what is known in the formal sense as brutalism. Finding its roots from Le Corbusier's term 'béton brut', meaning bare or raw concrete, the brutalism movement emerged in the 1950 s and gained massive popularity into the 1970s. Characteristically unadorned, simple, heavy block-like forms, Skenderija's architects were able to make the brutalist concrete mass into a poetic version of itself. Its softened edges, concrete casted details resembling carpentry, and enough formal sentiment pulsating through it, Skenderija is a beautiful expression of monumentality, complimented by the mountainous landscape it's nestled into.

Gathering citizens and visitors alike on a total of 70,000 square meters, Skenderija's individual parts connect under a unifying roof that alternates open versus tightly covered pedestrian communications. Throughout the decades it has become a cultural place of encounter in the city for all generations of Sarajevans. One significant point of interest within the urban network of Sarajevo is a sculpture called 'Figure on a Chair'. Erected at the entrance of the plateau after the siege, the woman with outstretched arms symbolizes the welcoming of all newcomers. For the last two decades, she stands as a reminder of resistance to the atrocities Sarajevans lived through. She greets pedestrians whether they are walking by, entering Skenderija, or using her as a meeting point. Nicknamed 'Teta Razapeta' by Sarajevans, she was designed before the siege by Alija Kučkalić, a renowned Bosnian artist and sculpting professor at the Academy of Fine Arts in Sarajevo. Holding the greatest award of the arts in $\mathrm{BiH}$, Kučkalić was sadly killed during heavy bombing on June 22, 1992. Teta Razapeta's presence has become synonymous to Skenderjia, and despite the complex's neglected appearance, its architecture and urban spaces demand to be reacquainted with the vibrant socio-cultural life of Sarajevo. By respecting these identifying characteristics within its design, this thesis aims to restore Skenderija's pedestrian communications through the inclusion of newly integrated public spaces that marry the existing points of interest. 


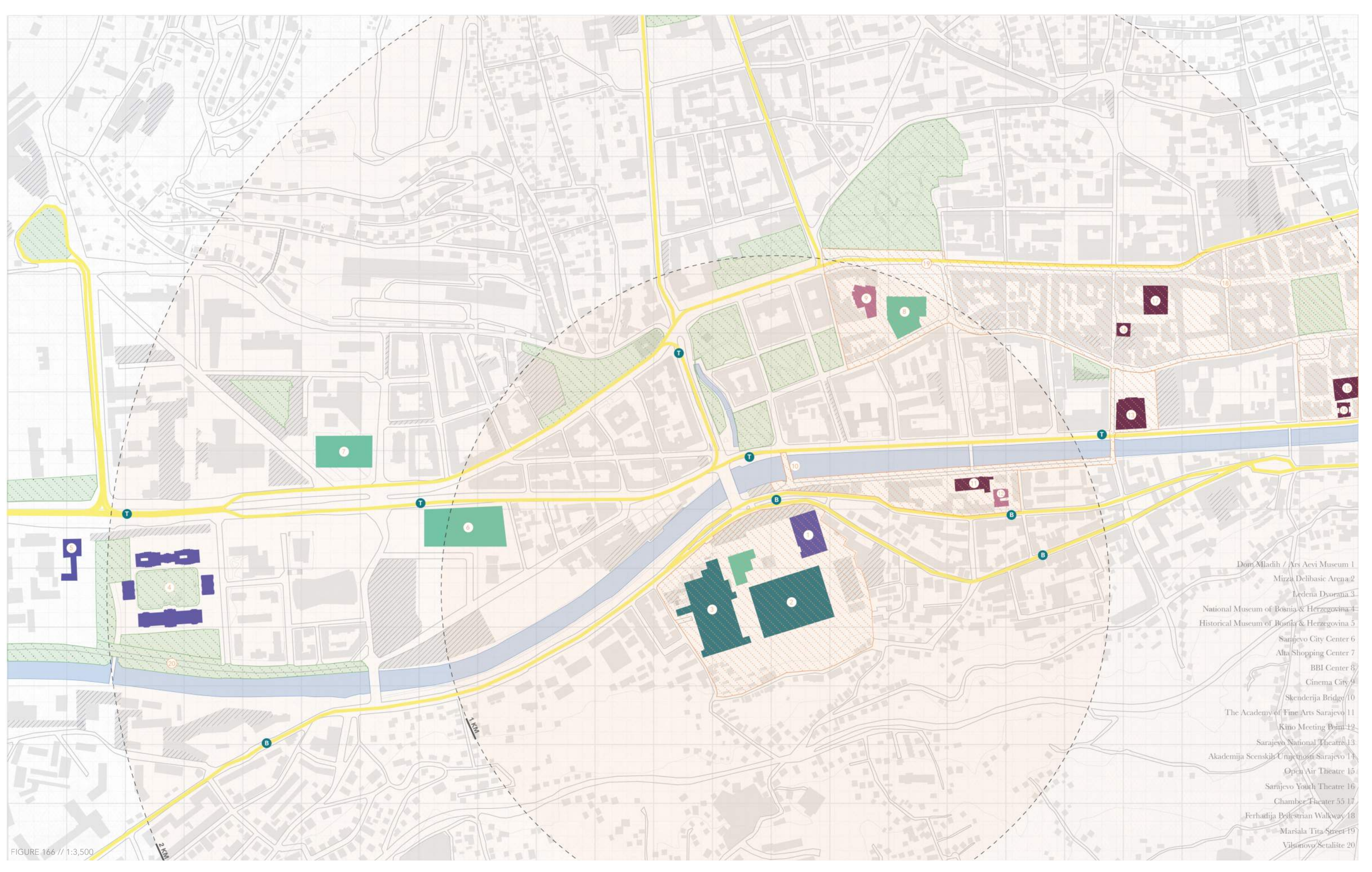




\section{SKENDERIJA TAKES CENTRE STAGE \\ // CULTURAL REINTEGRATION}

Situated perfectly within the city, Skenderija's most blatant obstacles lie in its lack of architectural and urban maintenance over the years. This has lead to a poorly connected zone, and as a result the absence of presence on site. In order to attract visitors, the community needs cultural engagement to bridge the gap in communication between its parts. The proposed design focuses on architectural intervention, cultural integration, and social connections. Skenderija already possesses the cultural density of sporting, museum, and youth facilities on site, and needs to rejuvenate its public space and social connection to Sarajevo's post-war ways of living. By the introduction of a film and events space, and linking the site by incorporating new and interesting activities for its varying landscapes, Skenderija will once again be an active part of the city tissue.

Architectural intervention begins with Ledena Dvorana. To strengthen the main composition axes in Sarajevo's urban heart, an emphasis is placed on the addition of a conference and events centre inside Ledena Dvorana's shell. Being a cultural city with a prominent arts and film scene, a centre of this calibre can act as a gateway between its east and west programs. Largely concentrated to the east, theatregoers can cross over to the west, and the museum buffs from the west are given the same opportunity, gathering at Skenderija. With the creation of this hall, the intention is for a diverse array of social, cultural, and economic needs to be met. As Sarajevo is internationally renowned for its eclectic and diverse selection of over 50 annual festivals, integrating the use of Skenderija's public indoor and outdoor spaces is fundamental in design. With multi-use space, administrative space and classroom or workshop spaces, the newly designed Ledena Dvorana allows for the surplus of any program being held at Skenderija's sports or youth halls to spill over seamlessly and be used in conjunction. Designed for 

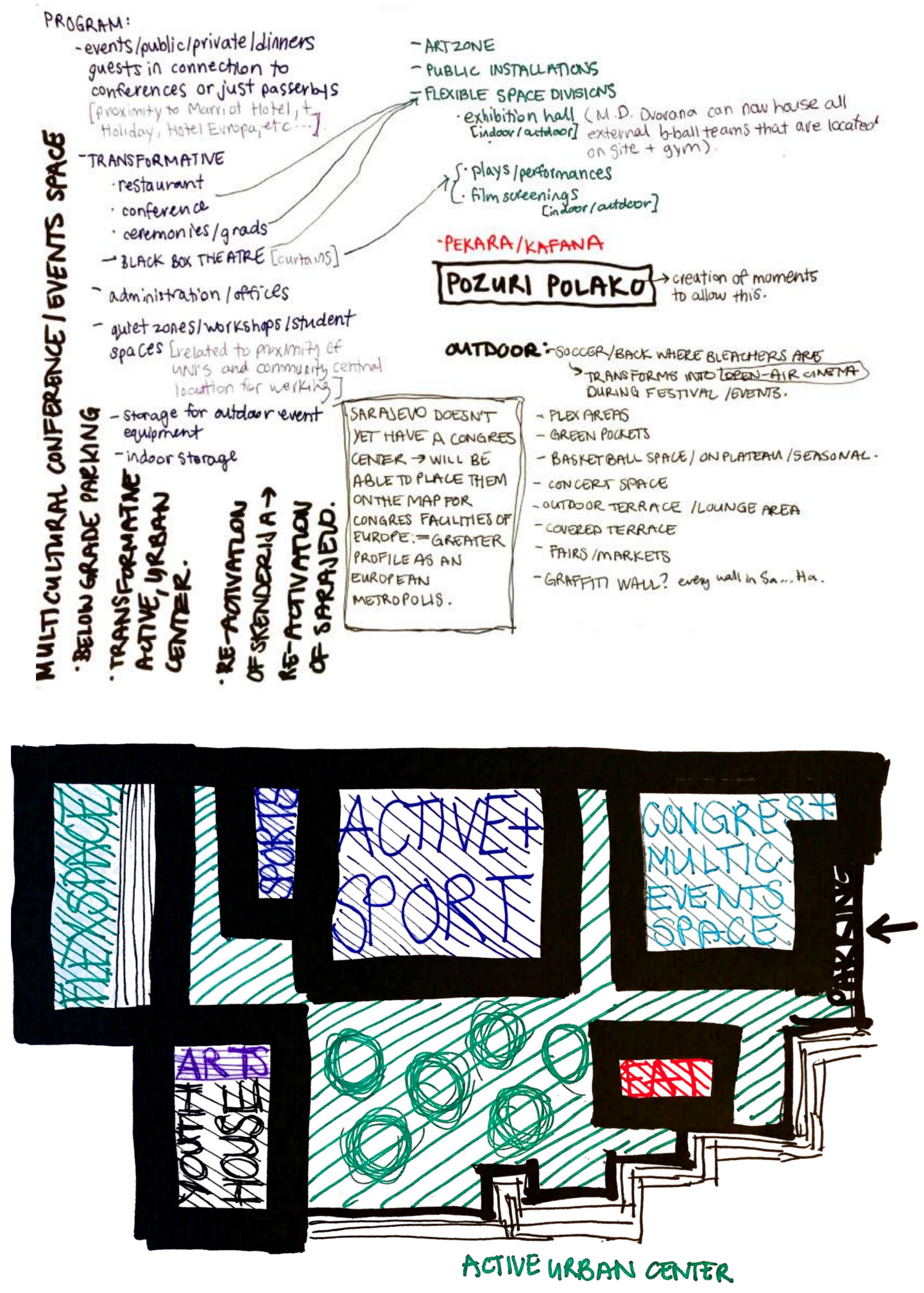

FIGURE 167 // 

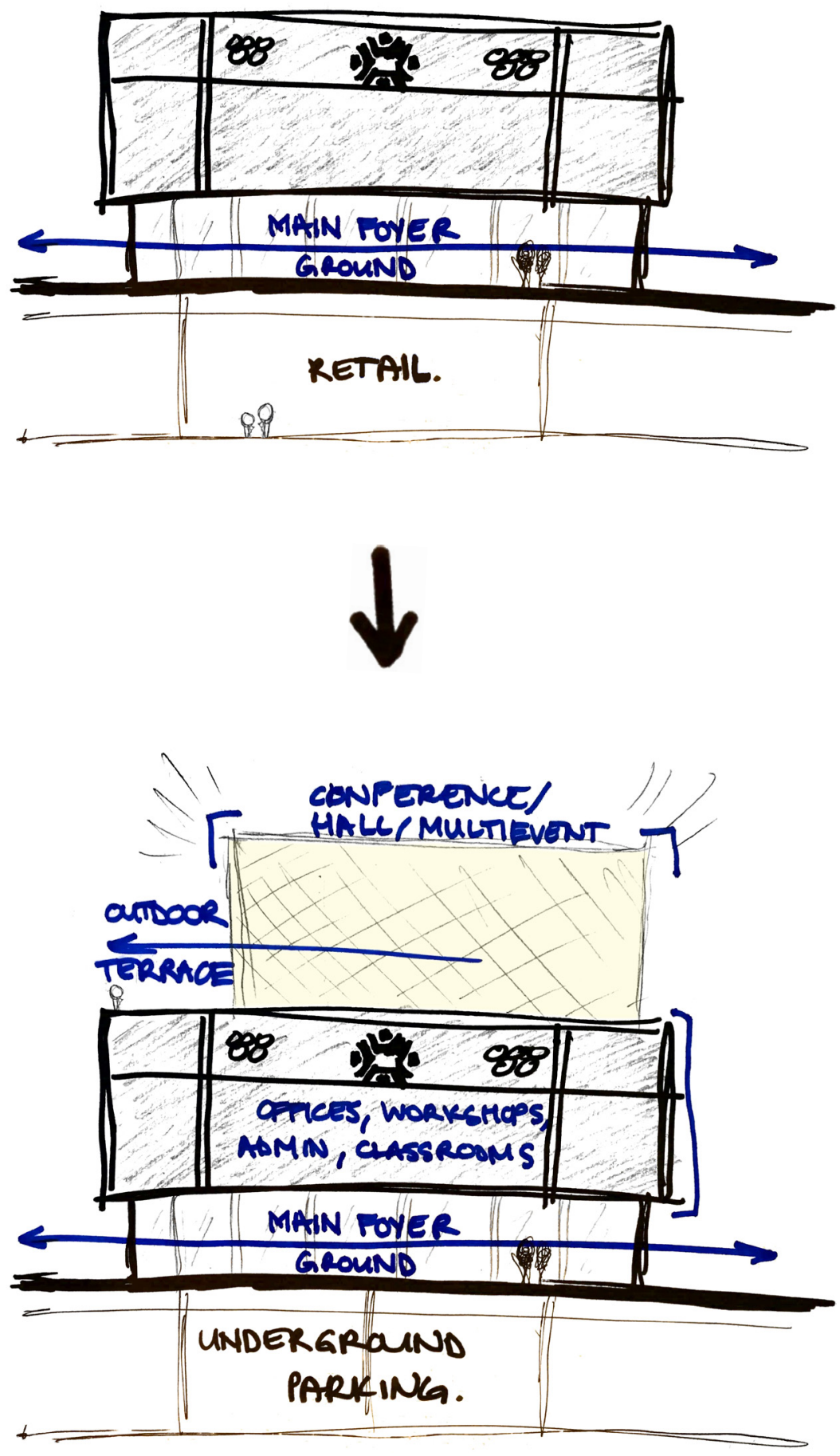

FIGURE 168 //

142 
Sarajevo's needs toward a lecture or concert hall, congress space, wedding and event reception, film education and production, black box theatre or cinema, the flexibility of the space allows for easy transitions between them all. For lectures, conferences and fairs, the space can be divided into two separate rooms with the addition of a sliding wall for desired use. For requirements of presentations, movies, concerts, and black box theatre performances, stage curtains along the perimeter of the walls can be drawn all the way around the space with large canvas screens for the displays. For wedding event receptions, the light, airy, façade with riverfront glazing looks onto the Austro-Hungarian town; this makes for an incredible atmosphere. Parking needs for the accommodation of large events with large groups of attendees are met with the addition of below-grade parking. With the empty commercial shops below the plateau, the repurposing of this space offers a practical solution.

Aesthetically, the light, transparent addition atop Ledena Dvorana aims to enhance the existing buildings through its material palette and sensitive approach. It's intended to complement and harmonize the concrete language, not replicate or compete with it. The addition, with its light glazing façade, appears as if it's floating above Ledena Dvorana's roofless shell. A view that Sarajevans are so accustomed to seeing, this provides a new compelling visual identity. During the evening, the addition lights up against the mountainous backdrop, enticing pedestrians onto the plateau beneath. The position of the building in Sarajevo's cross-axes at the bottom of the river valley, making it so visible both during the siege and the Olympic games, is now seen as a beacon and a new symbol of hope.

Cultural integration of Skenderija is done through the inclusion of internationally renowned annual festivals by providing functional space and facilities for their use. The most significant festival in the city, happening annually every summer, is the Sarajevo Film Festival (SFF). As previously discussed, a genuine child of war, SFF emerged as an act of cultural resistance 


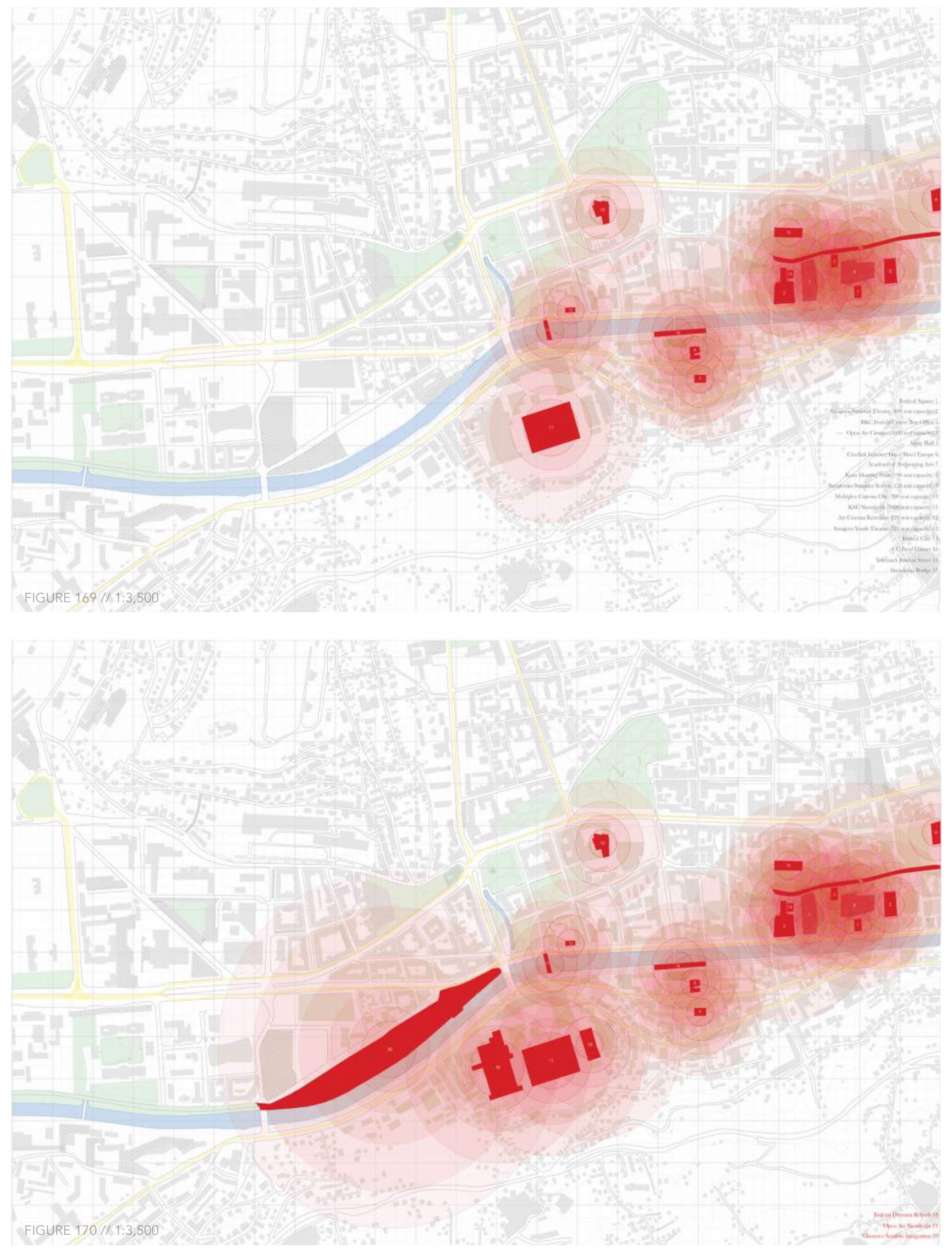




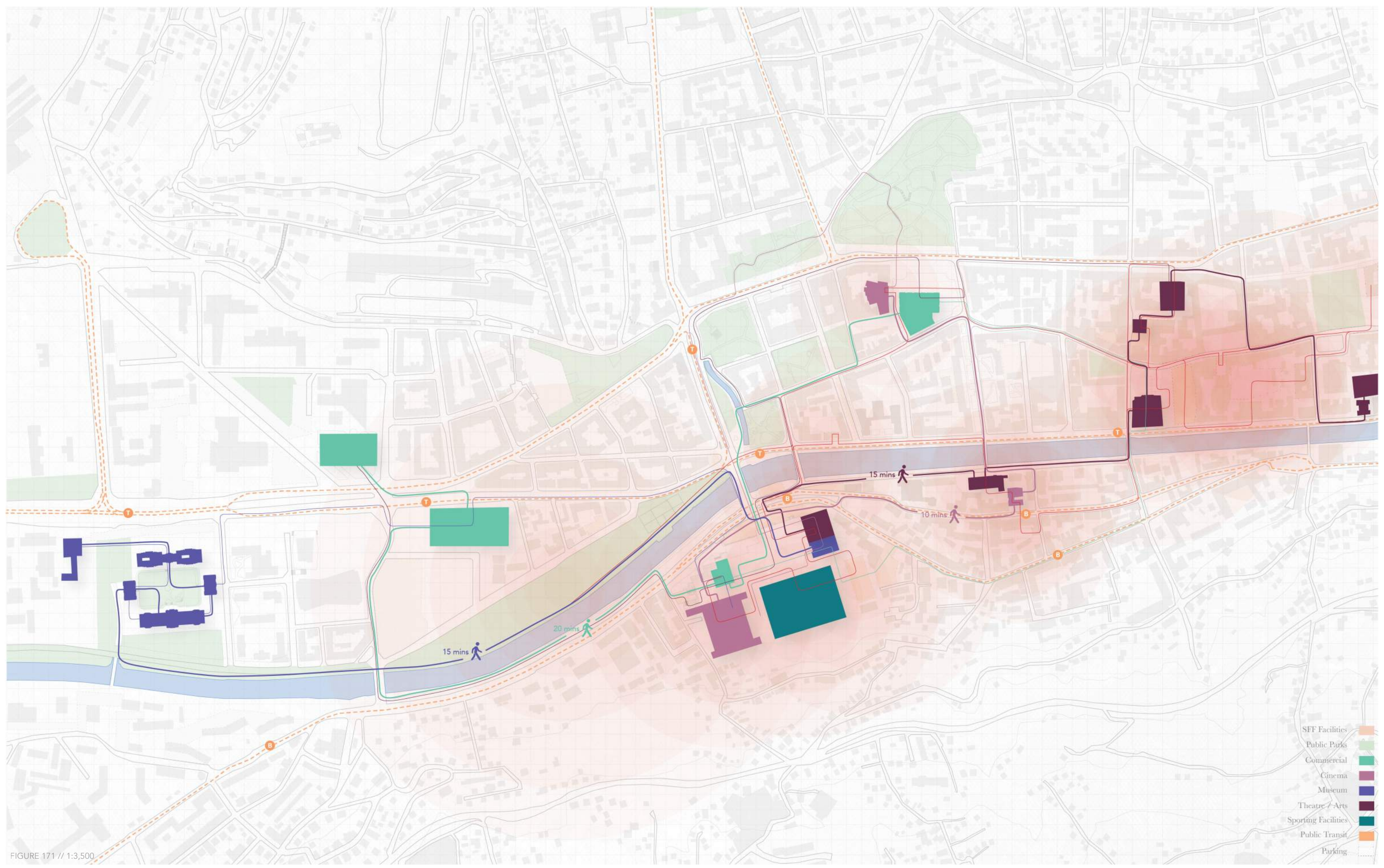


during the siege, enabling Sarajevan's to retain their humanity. Presently, SFF has grown into the leading film festival in southeast Europe and is internationally recognized by viewers and professionals as such. During the festivities, the Skender Bridge is utilized as an events corridor with music, lights and dancing. This brings visitors from the eastern facilities towards Skenderija, but not into the site itself. By activating Skenderija according to the ideas of Skender Bridge, a permanent invitation onto the plateau and Ledena Dvorana can be established (Figures 169-171). As SFF continues to expand and attract more visitors each year, it is reaching its physical boundaries and getting closer to encountering insufficient infrastructural capacities of venues. The opportunity to use Skenderija's plateau for outdoor activities, as well as Ledena Dvorana for film screenings and workshops, SFF is given the space to continue flourishing. With the addition of an outdoor flex space to the southeast corner of the site, concrete cast bleachers create the perfect outdoor environment for an open-air theatre during SFF and recreational activities throughout the remainder of the year. With the vast amount of Sarajevo fairs and festivals that happen weekly, Skenderija's rejuvenated urban facilities will allow for flexible uses year round.

Establishing social connections begins with the revitalization of Skenderija's plateau and its attachment to Sarajevo's main pedestrian walkways. Although Sarajevo is a cosmopolitan city, its distinctive habits and patterns in socializing distinguish it from the rest of the world. Sarajevo's particular urban life of walking the city and sacred coffee time are socio-cultural nuances that must be integrated. First, the ruins located directly across the river, inhibiting the expansion of Vilsonovo Šetalište towards Skenderija, must be addressed. In terms of this site, my design proposal leaves it open for adaptive re-use in a way that will culturally connect the two sides. Through the removal of these structures that have been informally turned into settlements post-war, the waterfront pedestrian pathway and garden can continue into Skenderija. Secondly, the revitalization of Skenderija's plateau is mandatory through the planning of walkways and spaces for 


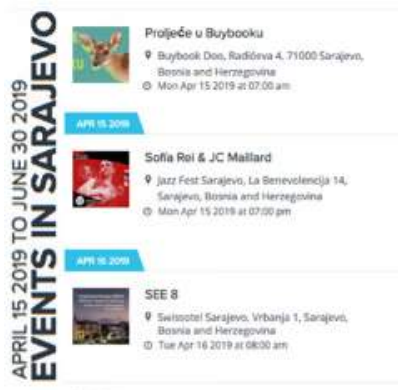

W4. Saraievo Business Fonm (saf) 2019 - Registrotion

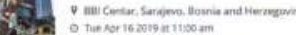

Antrang

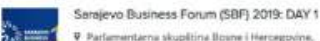

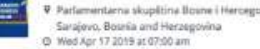

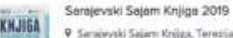

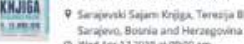

SBF 2019 - Welcome Dinner and Canure Prograrn

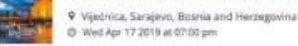

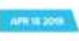

Sarajevo Business Forum (SBP) 2019: DAY 2

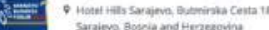

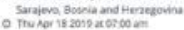

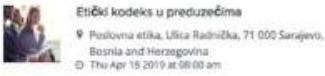

T. Maligyia Entrepreneur Camival 2019

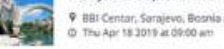

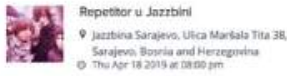

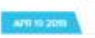

Saralevo Business Fonum /SBF 2019: DAY 3

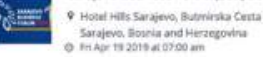

1. Romantétna vectera za dvojo u Summyantu

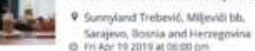

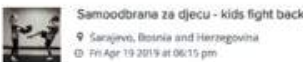

Thedstave Ko je ovde ition

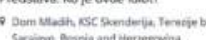

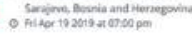

7. Kimur SHOCX // Sarajovo // 19.04. // Cinemas Sloga

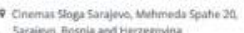

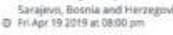

Emata Jahove

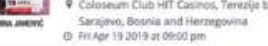

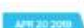

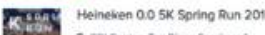

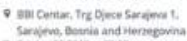

4. Uvodna foctionica iz Shema terapje

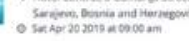

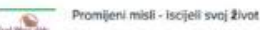

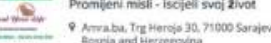

(8)

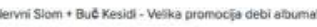

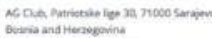

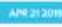

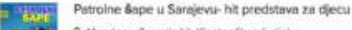

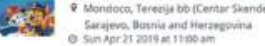

$\operatorname{sen} 2 x=0$

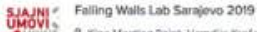

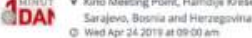

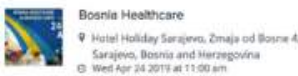

2.1. Sarajevo International Guihar Festival 2019

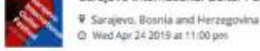

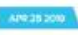

Fincont Conterence 2019

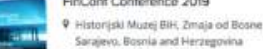

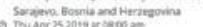

A4 Bakan Advanced Music - Conference fot Edton]

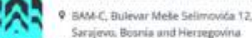

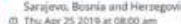

4. Interinationat Conference on Advances in Plant Sciences

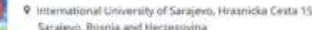

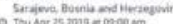

(48.

Ind inteernations Conterence on Advancos in Pant Sciences

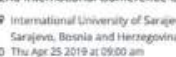

1. Ratel Aguire Concer

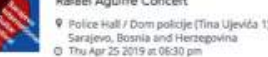

BaAMC by Nipht Day One / Opering Evert

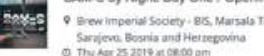

BAM-C ( Balkan Advanced Music Conterenese)

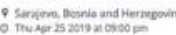

serszos

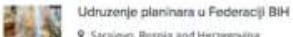

9.2.

Dercor sardievol

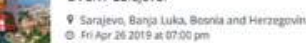

5. Duo Detoro Concer

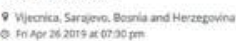

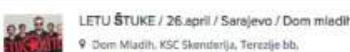

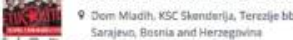

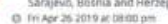

7. Decibei x BAM-C: Marko NastC., TRNO - SarajeOO

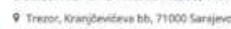

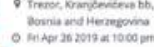

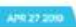

20. TEDrfentidialive - "Bigger than us" Simulicas

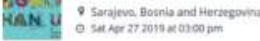

M. BeerDaps 2019. Festival della Bura Artigiande taliand

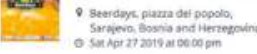

QZUMB 4 Sarajevo Zumbe Mastercliass

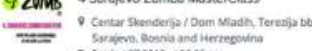

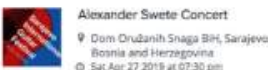

f) Bam-Cby Night Day Therec

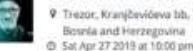

sencinesen

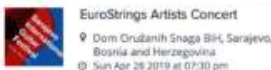

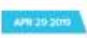

Los incuietos del Norte and E Filly y sus Aliodos
at Cliub Tropics (April 28, 2019)

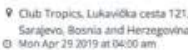

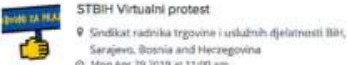

2. Atanas Ourkourounow, Corkoumak "Corona" Concert

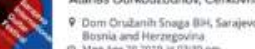

morizon

F1. Drunstance t. Maf Open Air (Day 8 Night

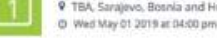

$\operatorname{mex} 200$

17. 20. Seminar Tal II Guan- uvod u Chen stll, Sarajevo

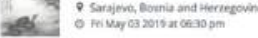

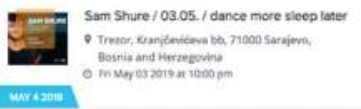

inte Moloss Matness 2019

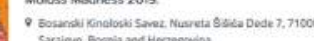

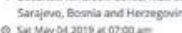

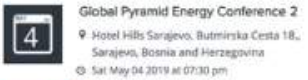
$\operatorname{mars} \min$

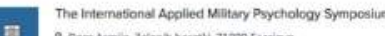

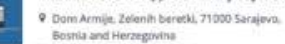

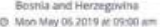

maresos

is:

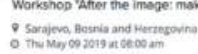

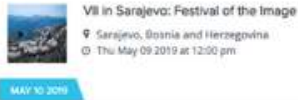

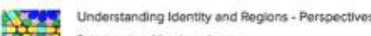

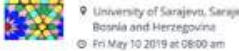

Danny Howelis / 10.05. / dance more sleep Intef

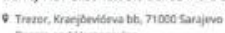

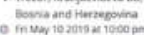

vartinit.

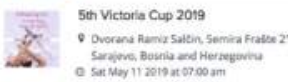

Yarg. Aastrango Vinyasa Yoge for All.

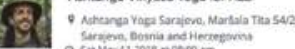

IYS EASY Flossing kurs Sarajevo

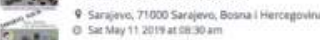

marasen

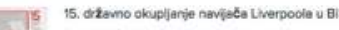

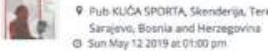

[utratain:

क्षै

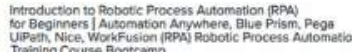

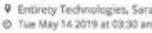

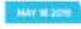

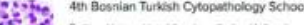

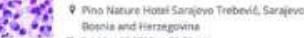

Marssom

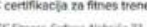

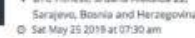

Fi. ERGON IASTM Basic Seminar SARALEVO

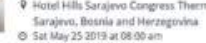

Fin Conered Resh / Pappy Seed Grinder / AG C CUD

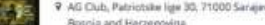
O Sat thar $252019200500 \mathrm{om}$

marabosen

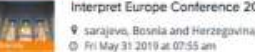

Fosiczons

플 SAMAT NEOGRANICENAH MOGUÉNOSTI

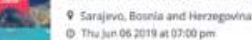

$\sin x=$

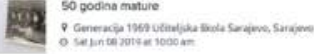

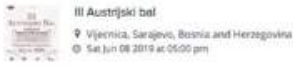

एक्षo:

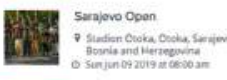

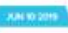

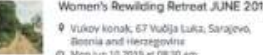

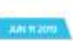

11911 Energe 2019

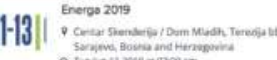

$\sin$

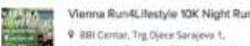

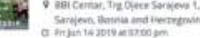

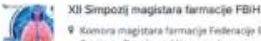

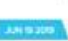

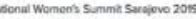

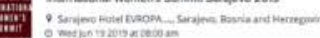

tamans

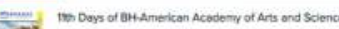

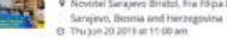

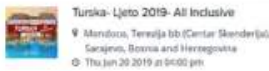

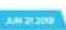

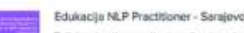

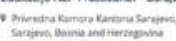

Gerden of Drooms Festive 2009

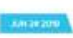

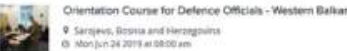




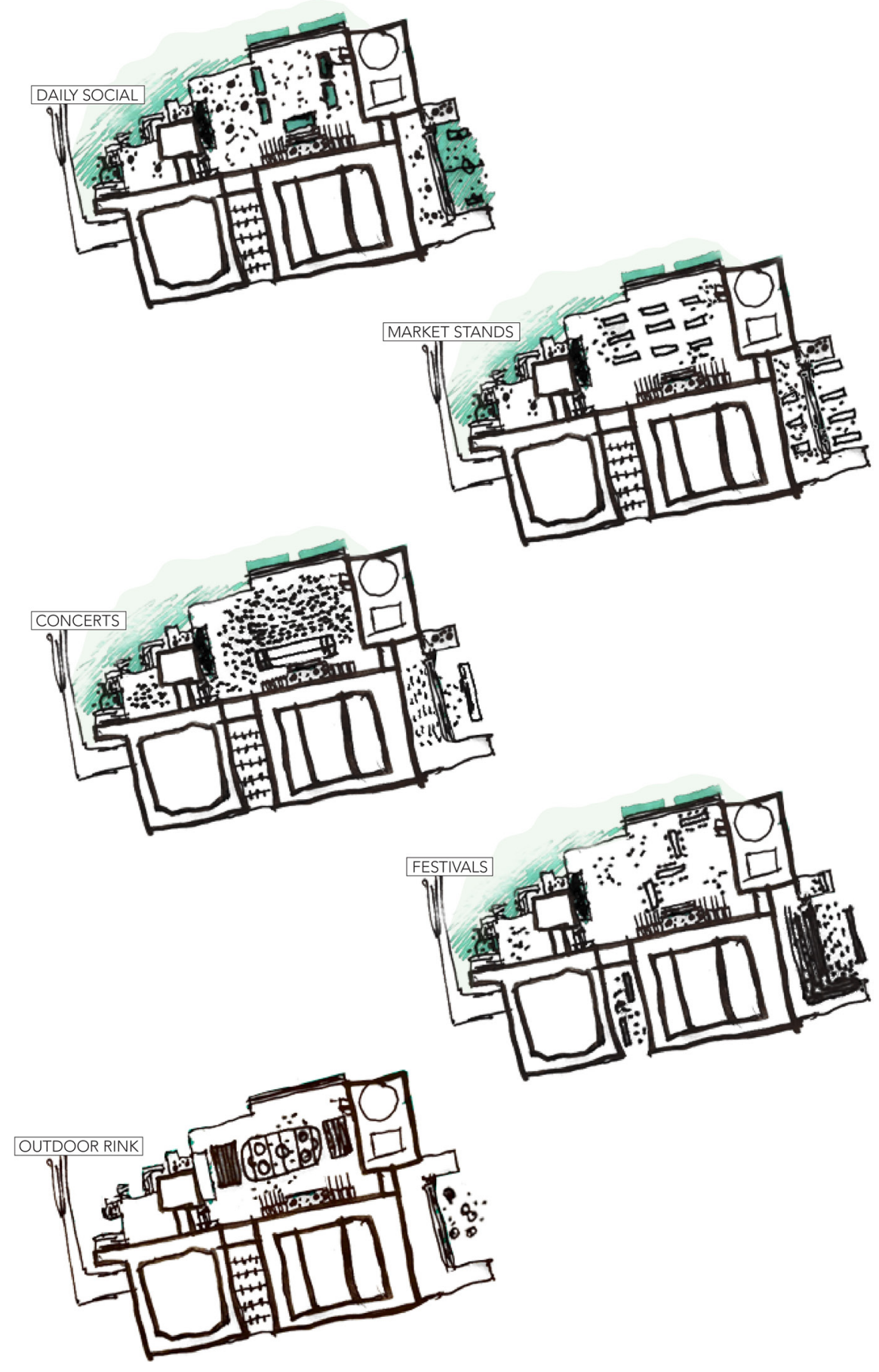


modern urban activities. In order to enable spaces of playing, gathering, and relaxation, the plateau offers content varying in services that will be used on a daily basis by all generations of Sarajevans. Apart from serving festivals and fairs, Skenderija's plateau provides an open urban location for social functions such as, farmers' markets, outdoor recreational sporting games, and organized yoga or meditation classes - creating formal and informal gatherings for a city of high social competence.

When it comes to urban spaces, supply creates demand; therefore, revitalizing Skenderija's plateau builds a new community space that may stimulate Sarajevo's contemporary social habits. The inclusion of a restaurant and café gives visitors new places to pause and enjoy Sarajevo's mentality of intensity done at a very leisurely pace. The concept of sitting back and people watching or being people-watched is ever present on the plateau, just as well within Sarajevo's social dialogue. As simple as it sounds, to allow this form of contact to happen people tend to sit where there are places to sit. Making changes as straightforward as doubling the number of places to sit, will in turn double the number of people who are seated there, significantly improving the patterns of use. With seating, social interactions and lingering are encouraged, making the plateau more than just a thoroughfare. As the plateau is intended for varying events and temporal installations in its seasonally changing landscape, the use of non-fixed seating throughout its surface allows the ability for visitors to freely use the allocated spaces per individual needs.

Whether you find yourself at Skenderija to play sports, meet for coffee, go to the museum or leisurely watch the city go by, each activity will promote an environmental experience alongside other Sarajevans. Through its solid and fluid states, visitors move through the plateau by open and covered pedestrian communications drawn from its prominent periods of history. Mimicking the organization of the Ottoman town, narrow passageways open into spaces located out of the public eye. Through the public life of seeing and 
being seen, the public spaces of the plateau act as an Austro-Hungarian gala stairway. The socialist era that influenced the recreational needs of cities and large spaces of cultural gathering is already built into Skenderija's physical and emotional presence. These additions and modifications to the site, including the lantern that lifts its profile and opens it to the valley, draws the design into new hybrid conditions and patterns of life in Sarajevo.

During the siege, Skenderija's visibility from the sniper posts and proximity to the front line came as a hindrance to the complex. Today, the case of its visibility, not just from street level but also from all angles of it surrounding context, is celebrated. Being able to promote events and festivals on its plateau, as well as attract visitors by the sole appearance of people gathering on its surface from afar is an aspect of Skenderija that cannot be found anywhere else. 


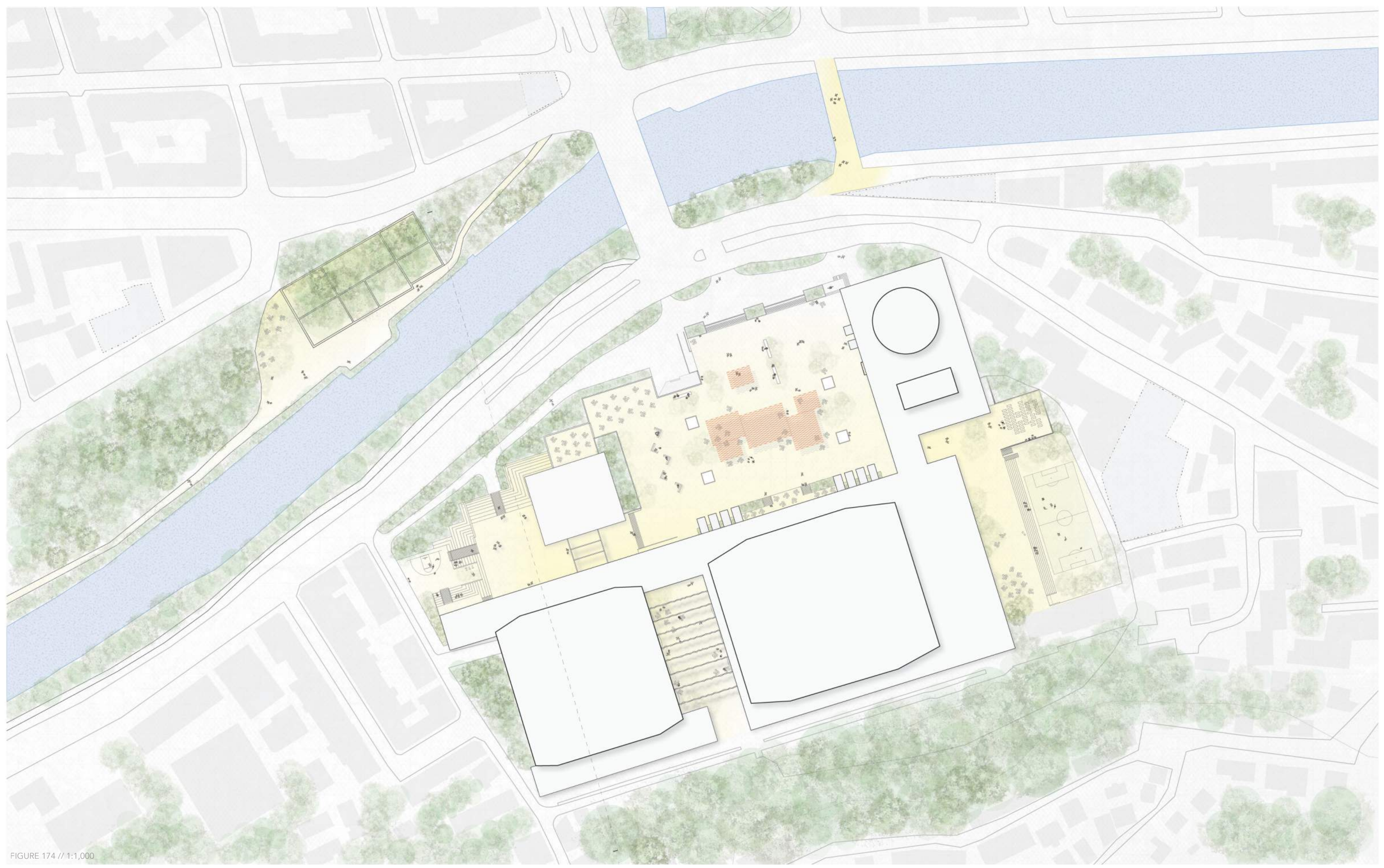




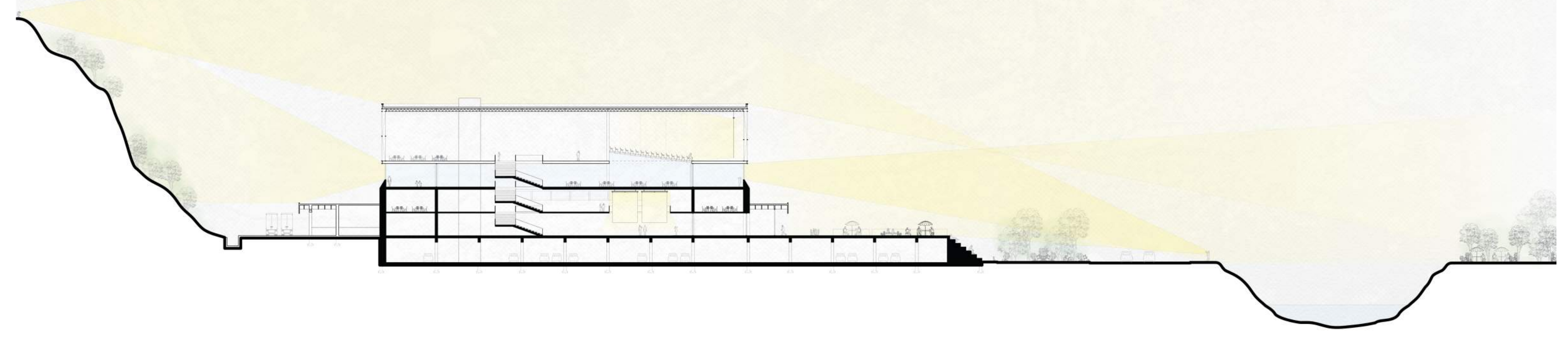




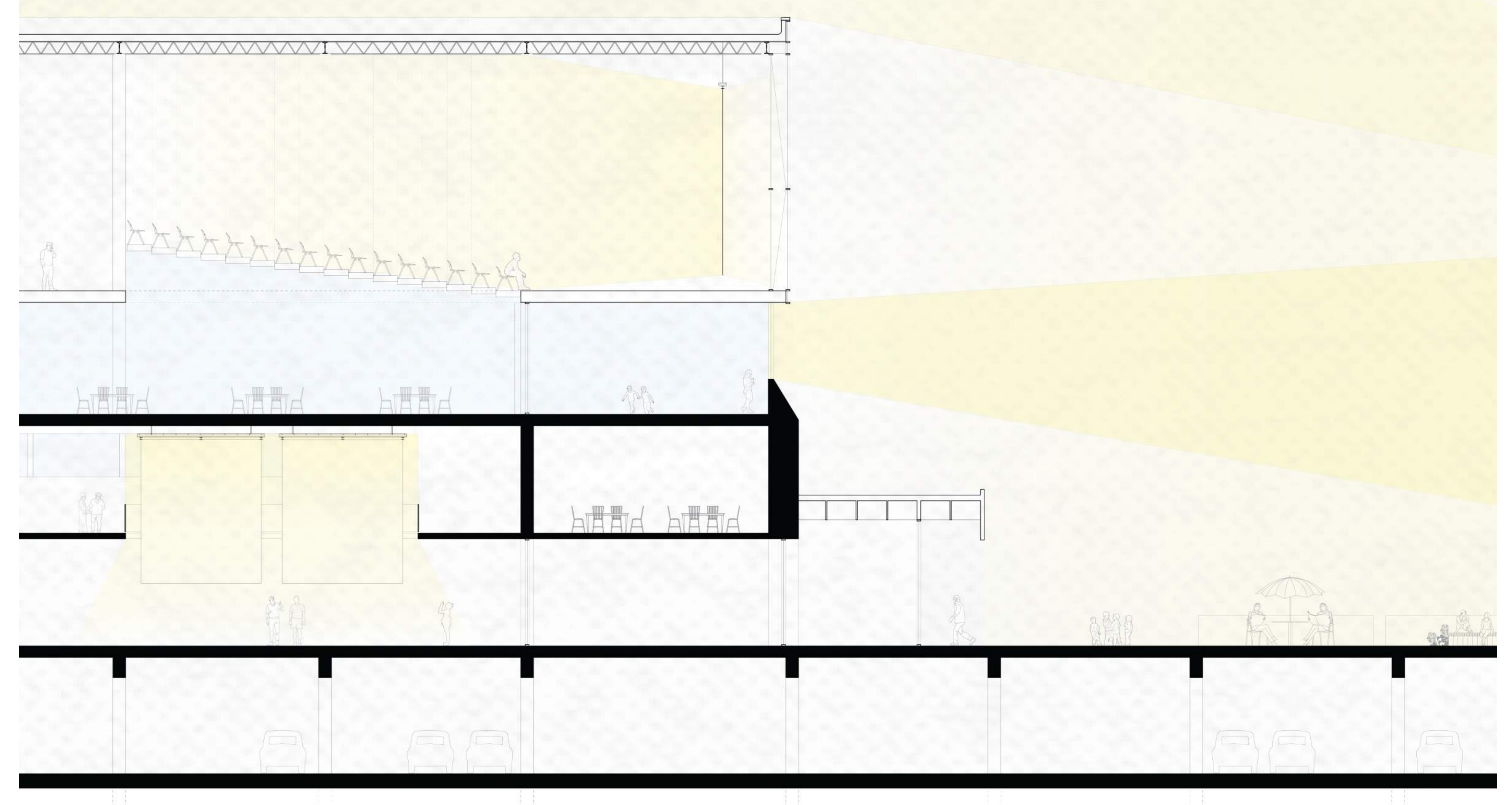




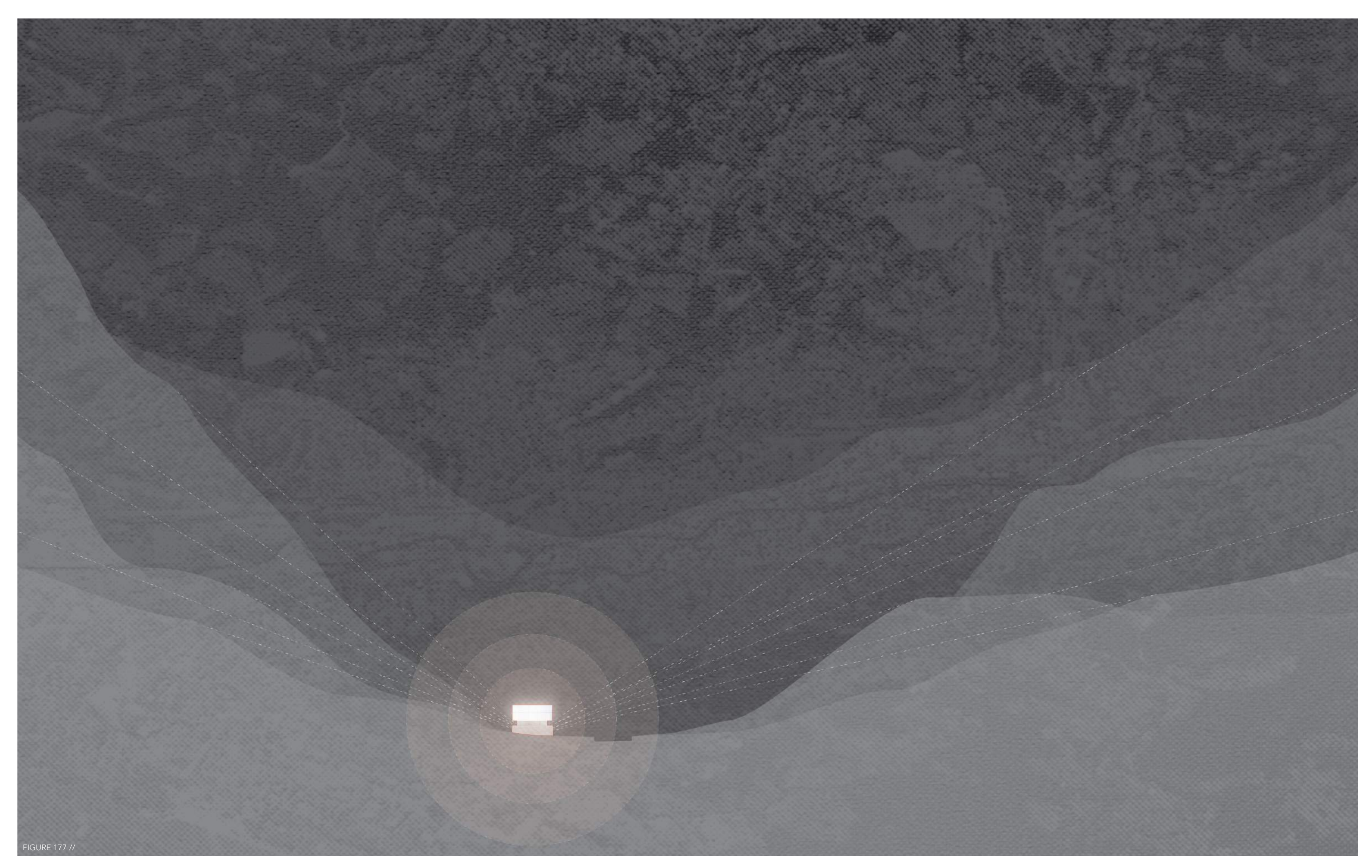




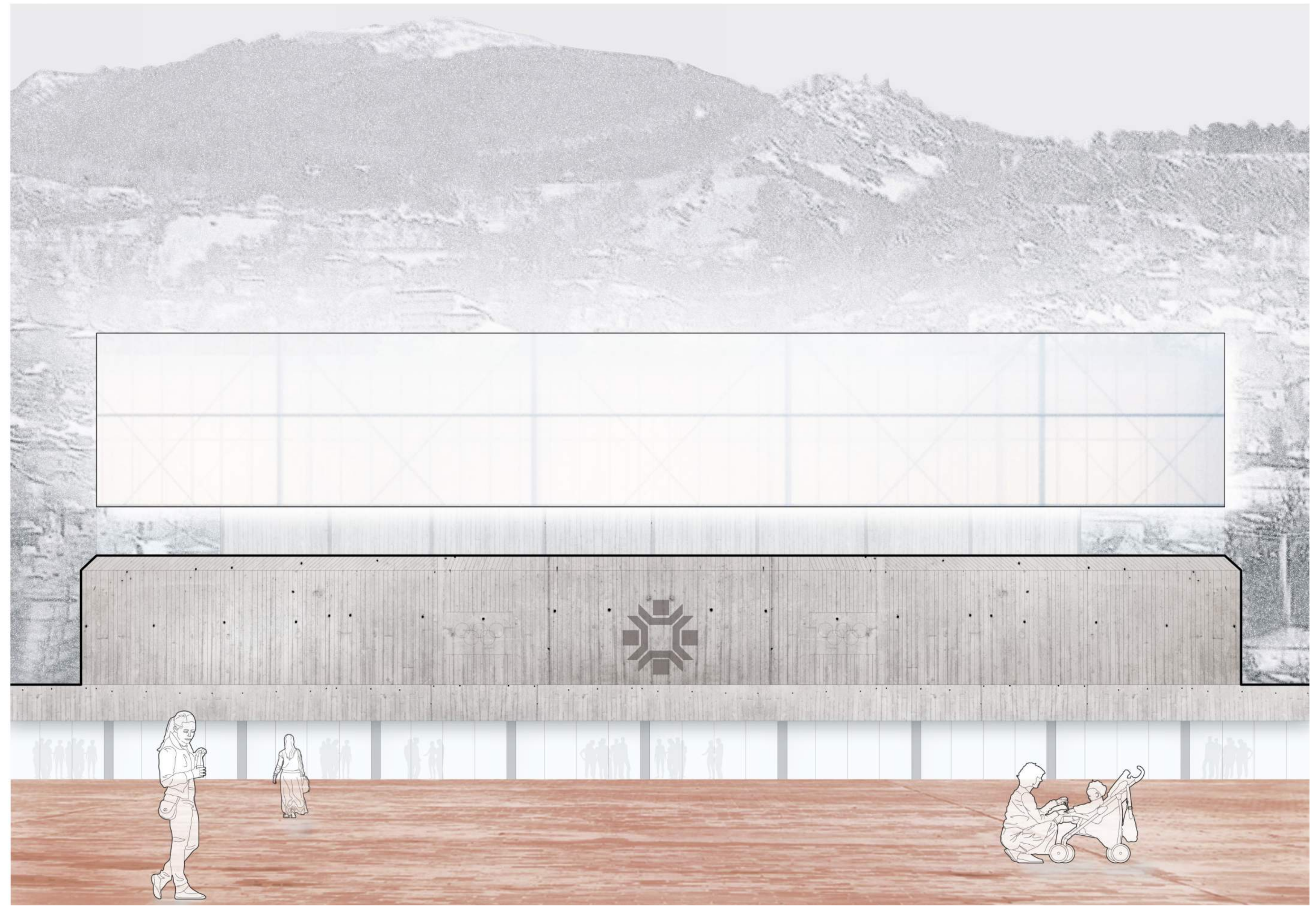







Crepe cook-off happens at KSC Skenderija's Mirza friendly competition for one of BiH's all time favourite dishes.

With cooking and judging organized for the interior, while spectators wander about, crepes are and consumption. Heating lanterns and seasone fire-pits are located below the terracotta canopy socialize.

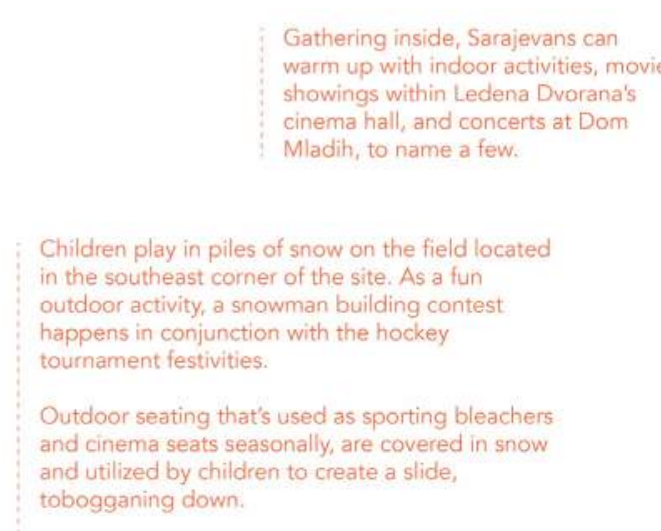

Film students prepare their final screen and in poster, all month long. With flexible classroom spaces that open up into open gal ery space with removal walls, screen caps of students' work, as well as their movis disptra ade printed on canvas and open plan.

As every other day commences the projection of another student's film arge sheet posters are hung throug At double height atrim space.

At the end of the month, a large celebration takes place in Ledena flattened and theatre seating removed.
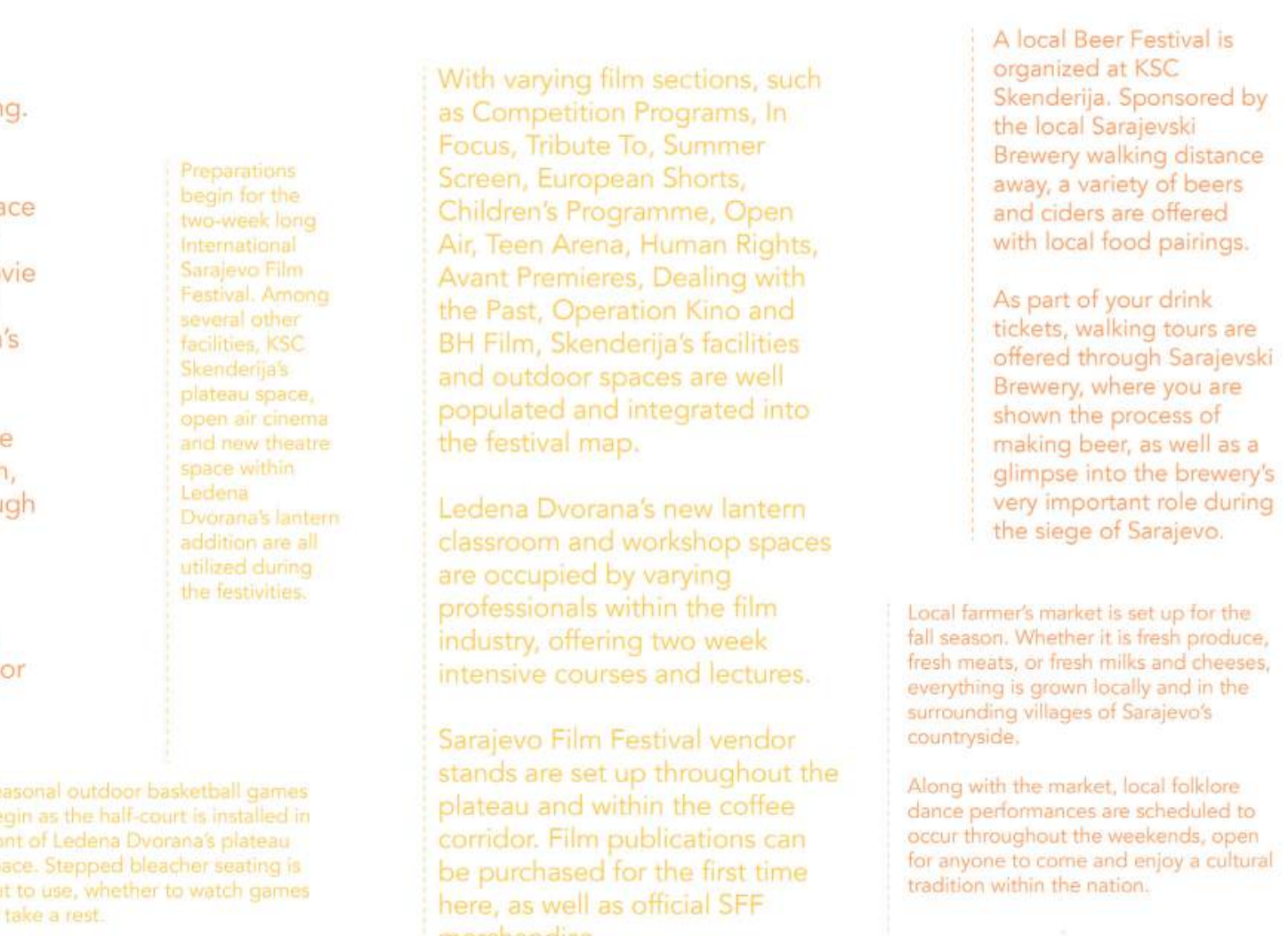

'Evening Under

the Stars,' a

student works

half of the year

is put on

friends.

An opportunity
for quests to

relaxing nigh

in Ledena

lantern space,
watching films
leaming

learning and
socializing
hofing

socializing
before the

holiday break.

\section{jan feb mar apr may jun july aug sep oct nov dec}

Temporary seasonal outdoor skating rink is Installed on KSC Skenderija's main plated The outdoor rink is accessible to allin

With varing levels of skills and activities, there are specific designated times blocked out for free skate, learning to skate for children, figure skating, and hockey.

With the rink open to all, the vendor stand from the coffee corridor is temporarily moved to the central plateanto senve warm beverages and treats to visitors.

A citywide, friendly hockey tournament is
organized on KSC Skenderija's seasonal

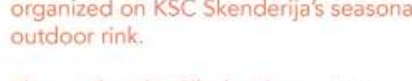
The weekend is filled with spectators
gathering around the plateau, sociali: Outdoor concert goes live in the local rock groups who began the careers at Dom Mladih in their youth, they join the rest of the city in

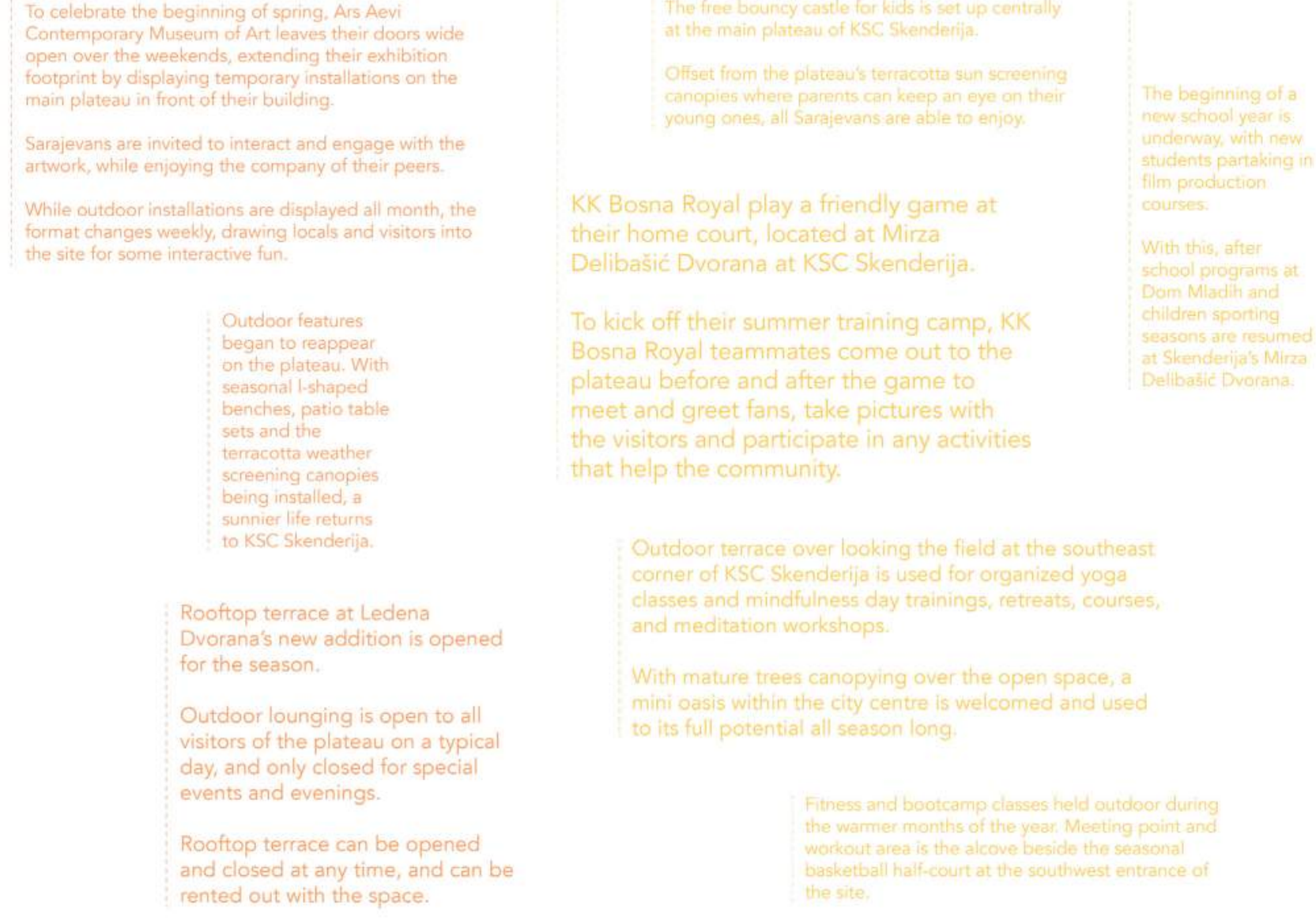

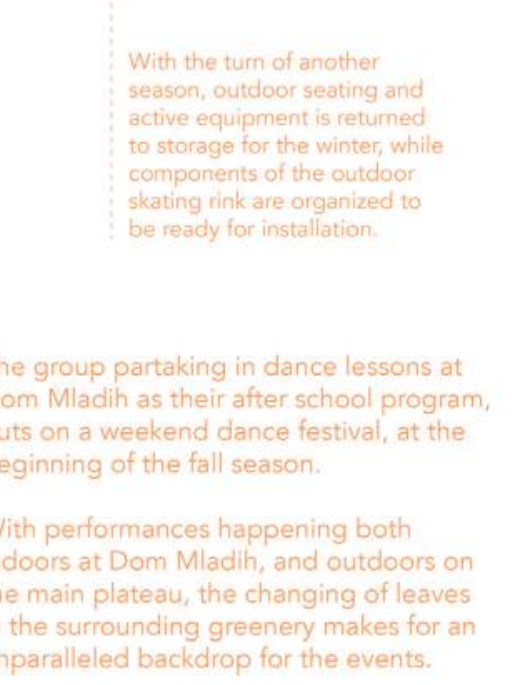

KSC Skenderiia's main plateau is set up as an ppen air cinema space, with a movie beting projected onto a hacinging canvas overtop of

Marking the turn of another season, outdoor activities and festivities within Sarajevo's 


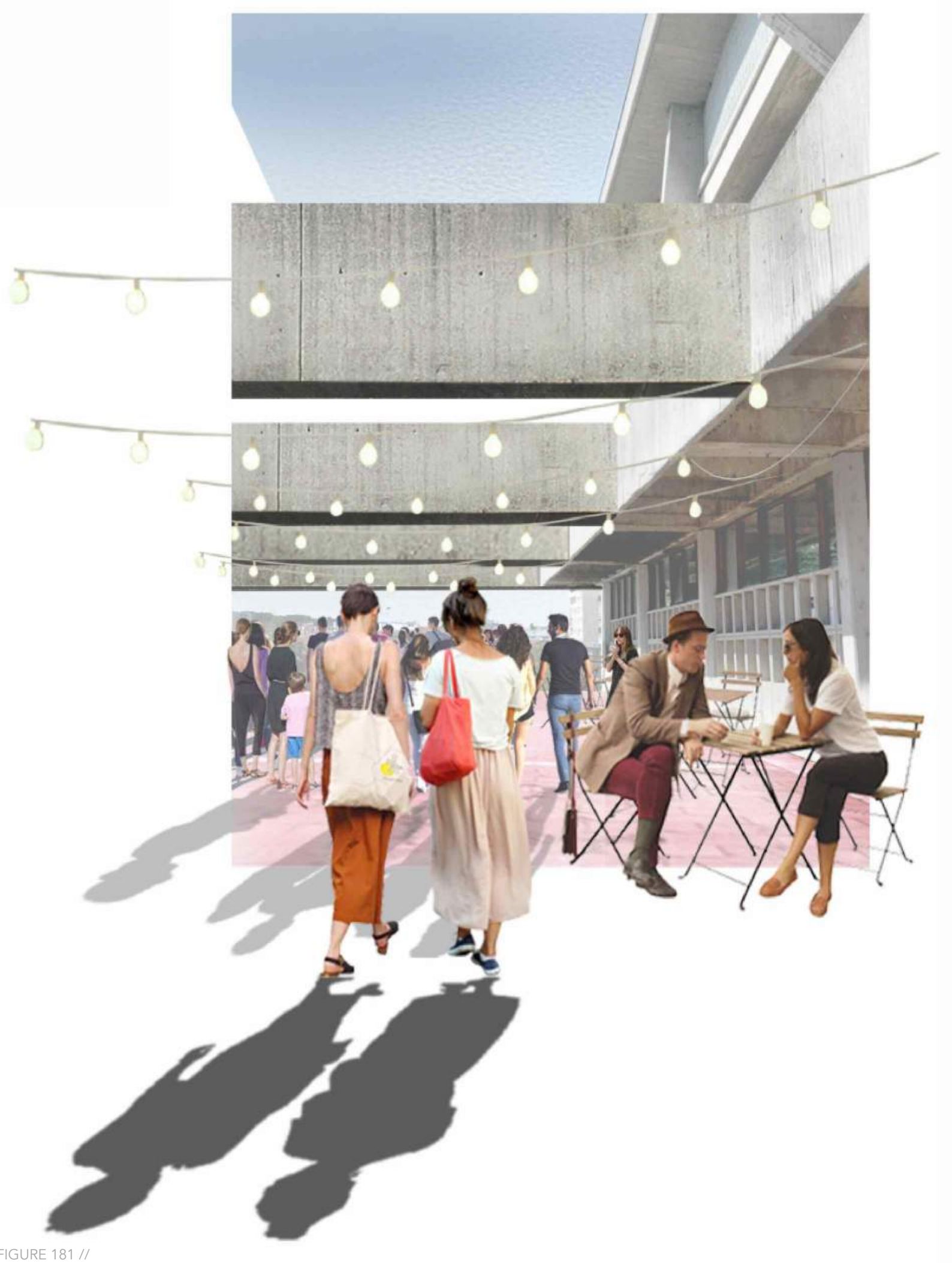




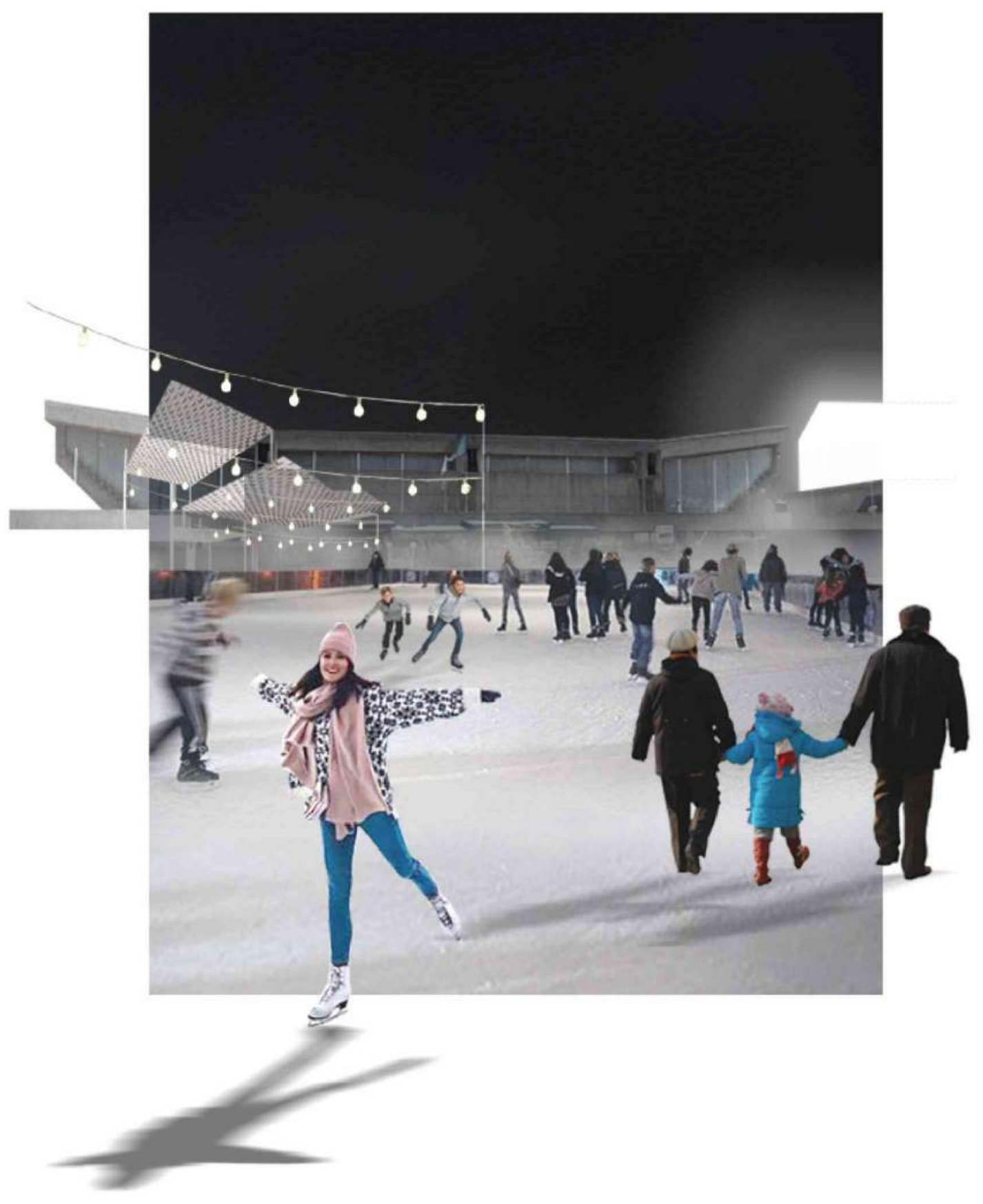




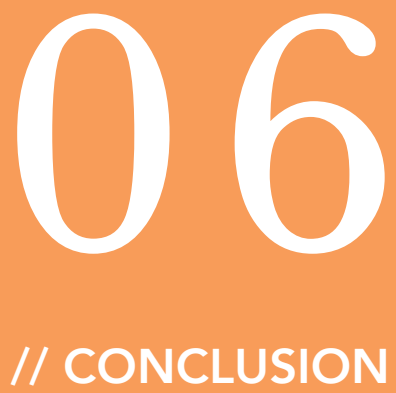




\section{CONCLUSION}

// THE SCARS OF SARAJEVO \& SKENDERIJA'S PLACE

Buildings are more than their physical assemblies. According to David Littlefield, they are "powerfully affected by human inhabitation and human practice." Skenderija has acquired many identities throughout its existence, all of which have been deposited into its fabric. Of past events that have been absorbed into its concrete, this thesis hopes to create a new Sarajevan collective memory of the complex. Building on the site's identity from the past, the core motivation of this thesis has been to reintegrate Skenderija into the city that passes by it everyday. The experience that this thesis intended to achieve is Tito's social Skenderija with a mixture of Olympic energy and vibrancy, and the rich culture of the city's deeper past and present. Through the recreation and reconstruction of this collective memory in the Sarajevan psyche, Skenderija can once again be a space where communities come together.

Throughout the duration of the siege, the landscape of terror enforced by the BSA inhibited flows of movement and paralyzed the city. This thesis strives to reverse this topography through structures and systems that invite people to publicly and multi-culturally gather at the heart of the city. I believe that architecture has the potential for, as well as the commitment to, social responsibility, so it was particularly important to me that I try to design a space where Sarajevo's distinct cosmopolitan way of living and its cultural nuances could be expressed, revealing and nourishing the soul of the city and its people.

By celebrating Sarajevo's prominent layers of architectural history, an unparalleled tapestry of new and old is rooted firmly into its urban life. This thesis aimed to enhance these spatial reconfigurations and qualities that impact the connective networks between public and recreational spaces 
on site. Although it has been argued that "Skenderija is probably the most impressive monument to the era of mature, liberal, market-consumeristoriented socialism in $\mathrm{BiH}$ and Yugoslavia," and therefore, its entire purpose. As our identities are interconnected with memory and history, we deeply rely on cultural and historical understandings of our societies in order to design successful spaces. Through reinventing the site of Skenderija, it was critical that this thesis further mend the emotional scars inflicted during the city's many pasts, creating frameworks for Sarajevo's socio-cultural structures to thrive. 


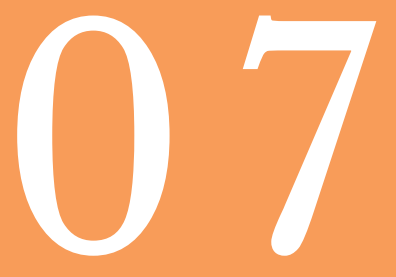

// APPENDICES

Glossary of Terms

Photo Dossier 


\section{GLOSSARY OF TERMS}

// APPENDICES

$\boldsymbol{B a s ̌ c ̌ a r s ̌ i j a ~ S a r a j e v o ' s ~ o l d ~ b a z a a r ~ i n ~ t h e ~ h i s t o r i c a l ~ a n d ~ c u l t u r a l ~ c e n t r e ~ o f ~}$ the city. It was built during the Ottoman Empire.

$\boldsymbol{B i H}$ Bosnia \& Herzegovina.

Bjelašnica Olympic mountain in Sarajevo. Mens alpine skiing was held here during the 1984 Winter Olympic Games.

Bosniak South Slavic nation and ethnic group found in the Balkans, mainly inhabiting BiH. The term Bosniak replaces Bosnian Muslims.

Brčko a small town, municipality and administrative seat of Brčko District in northern $\mathrm{BiH}$. Bordering Croatia, it is the only existing entirely selfgoverning free city in Europe. As part of the Dayton Peace Agreement in 1995, Brčko was not given to either entity of $\mathrm{BiH}$, and was left as a neutral territory.

$\boldsymbol{B S A}$ the Bosnian Serb Army, also known as the Army of Republika Srpska. This was the self-proclaimed military of the Bosnian Serb secessionist republic during the Bosnian War.

Cellist of Sarajevo Vedran Smailović, known as the "Cellist of Sarajevo," is a musician from $\mathrm{BiH}$, who, during the siege of Sarajevo, would play for funerals and under the eminent threat of sniper fire. Smailović is most notably known for performing publicly following the bread line massacre in the early days of the siege, for 22 days straight. He did this on Ferhadija Street in the open, each day commemorating each victim.

Croat South Slavic nation and ethnic group found in the Balkans. A Bosnian Croat refers to the Roman Catholic ethnic population, and has no relation to a Croatian, who is a resident of Croatia.

Collective memory refers to the joint memories held by a community about the past. It can refer to any period in the past, however in the current 
context signifies the collective memories held of Sarajevo before the siege.

Community refers to a feeling of togetherness with others, as a result of sharing common interests, goals and mentalities; an identity.

Culture the social behaviour and norms found in human societies. The arts, humanities, literature and music, referring to what makes a society reach intellectual human achievement collectively.

Dayton Peace Agreement peace agreement reached at Wright-Patterson Air Force Base near Dayton, Ohio, on November 1st, 1995, and formally signed in Paris, France, on December 14th, 1995. These accords put an end to the 4-year long Bosnian war.

D-B Tunnel also referred to as the "Tunnel of Hope," the D-B tunnel was a tunnel traveling underneath the Sarajevo airport constructed by the Bosnian army during the siege. Starting in Dobrinja and ending in Butmir (hence "D-B"), it linked the city of Sarajevo that was completely cut off from life by the Serbian forces, to the Bosnian-held territory on the other side of the airport; an area controlled by the United Nations. The tunnel allowed for humanitarian aid to be given to the civilians and became the only way to "safely" flee the city. The tunnel, whose entrance was through the interior of the Kolar family's private home, was built over a period of six months using only pickaxes and shovels. Illuminated by 'war candles,' a container filled with cooking oil and fitted with a wick made from string, digging happened from both ends and met in the middle. The tunnel was 800 meters long, 1 meter wide, and 1.5 meters high. There was sometimes up to 1,000 people in the tunnel at once, with each man carrying backpacks of about 50 kilograms of food. Whether for the transport of supplies or the escape of mothers with their young children, an average of 4,000 people passed through the tunnel each day.

Dobrinja a Sarajevo suburb, isolated through much of 1992 by Serbian nationalist forces. It was the suburb where the D-B Tunnel started, linking the city of Sarajevo to "safety".

Dolac Malta a neighbourhood located in the Novo Sarajevo municipality of the city of Sarajevo. 
$\boldsymbol{F B i H}$ Federation of Bosnia \& Herzegovina is one of the two political entities that compose $\mathrm{BiH}$, the other being Republika Srpska.

Ferhadija pedestrian street in Sarajevo's city centre.

Grbavica district of Sarajevo under Serbian nationalist control.

Hrasnica town in the municipality of BiH. Located near the D-B Tunnel, Hrasnica was considered "safe" territory during the siege of Sarajevo.

Igman Olympic mountain in Sarajevo. Cross-country skiing, biathlon and ski jumping were held here during the 1984 Winter Olympic Games.

Jablanica a town and municipality located in the Herzegovina-Neretva Canton of the Federation of Bosnia \& Herzegovina, in BiH. Jablanica is located $80 \mathrm{~km}$ southwest of Sarajevo.

Jahorina Olympic mountain in Sarajevo. Womens alpine skiing was held here during the 1984 Winter Olympic Games.

Jugonostalgičari translated to "Yugonostalgics" is a psychological and cultural phenomenon occurring among former Yugoslav republics and its citizens, describing the longing for Yugoslavia in its pre-1991 state. The term is commonly used in a positive sense, referring to a nostalgic emotional attachment to desirable aspects of the SFRY. Possible avenues include economic security, sense of solidarity, multiculturalism, internationalism, traditions, and more rewarding ways of life.

Kafana term used in former Yugoslav countries for a distinct type of local bistro, café, tavern hybrid, serving alcoholic beverages, coffee, snacks and live music performances. This concept of a social gathering place for men to drink alcohol and coffee originated in the Ottoman Empire. It spread to Southeast Europe further evolving into the contemporary kafana. The word is derived from the Turkish "kahvehane," meaning coffeehouse.

Karadžić, Radovan president of the Bosnian Serb Parliament. In 2016, Karadzić was found guilty on 11 counts of war crimes and crimes against humanity and sentenced to 40 years' imprisonment. 
Koševo Stadium Olympic stadium in Sarajevo. It hosted the opening ceremony of the 1984 Winter Olympics, and is currently home to the professional football club FK Sarajevo.

Makarska seaside town located in Croatia along the Mediterranean Sea.

Memoricide Interpreted as killing of memory. Addresses the destruction of built heritage as a means of erasing traces of communities that had inhabited the city.

MESS The Festival of Small and Experimental Stages of Yugoslavia; an international theatre festival founded in 1960, MESS continues to be held every year in Sarajevo.

Miljacka river that flows through the center of Sarajevo. It is only $36 \mathrm{~km}$ in length, but the dozen bridges that cross it date back from the Ottoman Empire to the present.

Milošević, Slobodan nationalist president of Serbia, with the vision for a 'Greater Serbia'. He died on March 11, 2006 in his prison cell at the Hague while on trial for war crimes and crimes against humanity.

Mladić, Ratko the commander of the Bosnian Serb armed forces. In 2017, he was found guilty on 10 counts of war crimes and crimes against humanity, sentenced to life in prison.

Novo Sarajevo meaning "New Sarajevo," is a municipality in the city of Sarajevo. Novo Sarajevo is a product of the city's massive growth and development in the 1960s and 1970s, during the socialist era. Located in the middle of the city, it is predominantly on the northern bank of Miljacka River where there are numerous socialist housing blocks, as well as varying city corporations.

Oslobođenje meaning 'Liberation'. One of BiH's main newspapers based in Sarajevo and founded in 1943.

Partisans referring to the members of the National Liberation Army and Partisan Detachments of Yugoslavia; Tito's victorious communist guerrilla 
army during World War II. This was Europe's most effective anti-Nazi resistance movement, and a leading force in the liberation of Yugoslavia.

Požuri polako meaning, "Hurry, but slowly," also referred to as festina lente. Požuri polako perfectly depicts the way of life in Sarajevo. The mentality of Sarajevans is to slow down and enjoy the journey.

Republika Srpska one of the two political entities that compose $\mathrm{BiH}$, the other being the Federation of Bosnia \& Herzegovina.

Resilience the capacity to recover quickly from difficulties.

Resistance the refusal to accept or comply with something, and having the ability to not be affected, especially adversely. The resistance of civilians throughout the Siege of Sarajevo was regarded as a defense mechanism that greatly supported their survival.

Sarajevan someone from Sarajevo.

Sarajevo Rose name given to a concrete scar caused by a mortar shell's explosion, and later filled with red resin. Sarajevo suffered thousands of shell explosions during the siege. Wherever these marked mortar explosions are filled with red resin, it signifies 3 or more deaths at this particular location.

Sarajlije Bosnian demonym for Sarajevan

Sense of place feeling or perception often used in relation to characteristics that make a place special or unique; fostering a sense of authentic human attachment and belonging.

Serb South Slavic nation and ethnic group found in the Balkans. A Bosnian Serb refers to the Christian Orthodox ethnic population, and has no relation to a Serbian, who is a resident of Serbia.

Skenderija (KSC) 'Kulturni i Sportski Centar', meaning Cultural and Sports Complex, in central Sarajevo. First opened on November 29, 1969. It was later expanded in 1979 for the utilization during the 1984 Winter Olympic Games. 
SFF Sarajevo Film Festival. The premier and largest film festival in Southeast Europe, as well as one of the biggest film festivals in all of Europe. Founded in 1995, during the siege of Sarajevo.

SFRY the Socialist Federal Republic of Yugoslavia. Before its breakup in 1992, SFRY consisted of six republics: BiH, Croatia, Montenegro, Macedonia, Slovenia, and Serbia. It was proclaimed on November 29, 1945, and was governed by Josip Broz Tito until his death on May 4, 1980.

Sniper's Alley the unofficial name given to the main boulevard in Sarajevo during the Bosnian war. It became infamous as the most dangerous place for civilians to cross, as it was a large road connecting the industrial part of the city to the Old Town's cultural and historic sites, with little to no shelter. Snipers would hide in the surrounding mountains giving them safe distance and excellent views. In reality, every single street in the city should have been named Sniper's Alley, as there was always a possibility of being hit. The reason for this particular one being named was its proximity to the Holiday Inn hotel, housing foreign journalists and media personnel, therefore affecting them directly.

The Hague in this thesis, it refers to the United Nation's International Criminal Court located in the Netherlands. The International Crime Court has the jurisdiction to prosecute individuals for international crimes of genocide, crimes against humanity, and war crimes.

Tito, Josip Broz the former president of the SFRY and most commonly referred to as Tito. Tito was a socialist revolutionary and political leader, as well as the military leader of the Partisans. Tito is the symbol of unity. He maintained the peaceful coexistence of all the nations of the Yugoslav federation, gaining further international attention as the chief leader of the Non-Aligned Movement. Josip Broz Tito died in 1980.

Trebević Olympic mountain in Sarajevo. Bobsleigh and Luge track were held here during the 1984 Winter Olympic Games. Due to its position and higher elevation, during the siege it was the ideal location for snipers to hide and for the Serb army to launch artillery into the city

UNPROFOR The United Nations Protection Force. 
Urbicide term that translates into the killing of a city. Urbicide symbolically, or practically, destroys cultural or organizational aspects of a city as a political and emotional attack on the civilian population, by means of architecture.

Vijećnica Sarajevo City Hall, located along the Miljacka River in central Sarajevo. Built during the Austro-Hungarian Empire, the style is a pseudoMoorish expression. After WWII, the City Hall served as the National and University Library of BiH. During the siege, Serbs caused the complete destruction of the library, including the two million volumes, books and manuscripts. Vijećnica was reopened in 2014, following its reconstruction.

Vilsonovo Šetalište most popular pedestrian walkway in central Sarajevo. Stretching along the Miljacka River, lined on both sides with thick rows of trees, Vilsonovo goes from Dolac Malta neighbourhood towards Skenderija neighbourhood. The road is closed to vehicular traffic every weekday after 5:00 pm and on weekends and holidays. Lined with cafes and restaurants, parks and workout equipment, young and old alike, there are always activities happening here.

Vojničko Polje neighbourhood located in Novo Sarajevo. The socialist construction of this area was conducted post WWII in accordance with the general plan of development of Sarajevo.

Zajednički život the phrase meaning 'common life', and a term used by Sarajevans to convey the everyday practices of Bosnia's heterogeneity and hybridity. This common life was constructed as a form of mutual relations in which each person could live according to their internal identity. This above all means that of customs and religion, but also in which all people were connected by living and working together.

Zetra Hall venue for speed skating, figure skating, the ice hockey finals and the closing ceremonies of the 1984 Winter Olympic Games. 


\section{PHOTO DOSSIER}

\section{// APPENDICES}

Note for the electronic copy:

This thesis contains an appendix photo dossier. The appendix is a full collection of photographs depicting Sarajevo, Bosnia \& Herzegovina, throughout its most prominent periods of history discussed in the context of this thesis. These aspects of its history have translated into some of the concepts presented in the design. Within the thesis text are images I found to be the most striking - for the full series, please review the independent photo appendix. 


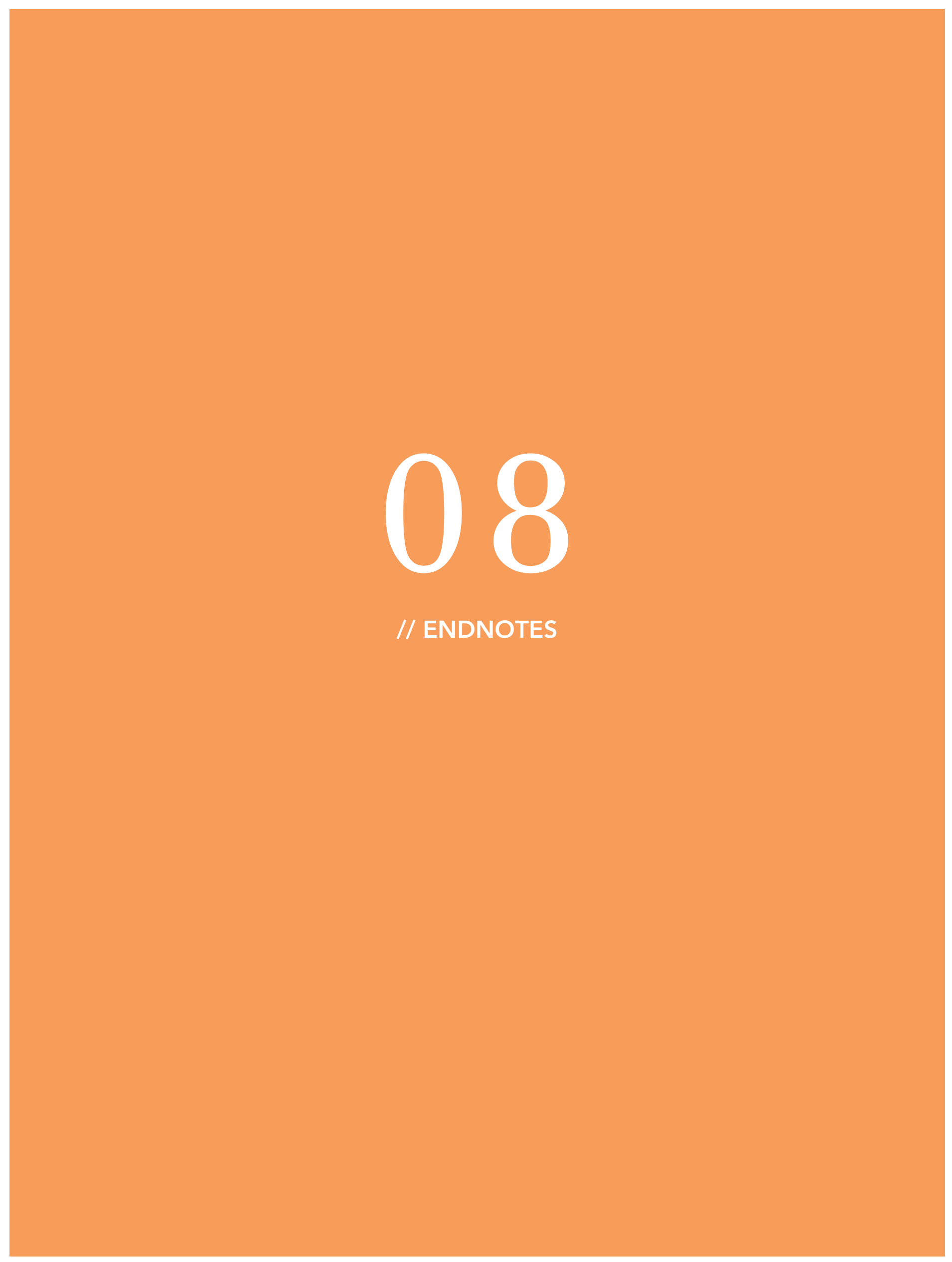




\section{ENDNOTES}

// THE SCARS OF SARAJEVO \& SKENDERIJA'S PLACE

THE OLYMPIC CITY

01. Valerijan Zujo, Sarajevo, (Rabic Publisher, 2006)

02. Ibid.

03. Ibid.

04. Ibid.

05. Jason Vuic, The Sarajevo Olympics: a History on the 1984 Winter

Games, (University of Massachusetts, 2015), 164.

06. Ibid.

THE BESIEGED CITY: A WAR OVER NAMES

01. Mirjana Ristić, Architecture, Urban Space and War: The Destruction and Reconstruction of Sarajevo, (Palgrave MacMillan, 2018), 16.

02. Tom Gjelten, Sarajevo Daily: a City and its Newspaper Under Siege,

(HarperCollins Publishers, 1996), 2.

03. Nigel C. Hunt, Memory, War and Trauma, (Cambridge University Press, 2010), 11.

04. Mirjana Ristić, Architecture, Urban Space and War: The Destruction and Reconstruction of Sarajevo, (Palgrave MacMillan, 2018), 51.

05. Tom Gjelten, Sarajevo Daily: a City and its Newspaper Under Siege, (HarperCollins Publishers, 1996), 141.

06. Robert Bevan, The Destruction of Memory: Architecture at War, (Reaktion Books, 2006), 33.

07. Ibid, 37.

THE BESIEGED CITY: A LANDSCAPE OF FEAR

08. Reif Larsen, Sarajevo's Enduring Optimism, (New York Times, 2015). 
09. Steven Galloway, The Gellist of Sarajevo, (Vintage Canada, 2009), 38.

10. Mirjana Ristić, Architecture, Urban Space and War: The Destruction and Reconstruction of Sarajevo, (Palgrave MacMillan, 2018), 51.

11. Ibid, 16.

12. Zlatko Dizdarević, Sarajevo: A War Journal, (Fromm International Publishing, 1993), 92.

THE BESIEGED CITY: RE-APPROPRIATING MEMORY

13. Robert Bevan, The Destruction of Memory: Architecture at War, (Reaktion Books, 2006), 36.

14. Mirjana Ristić, Architecture, Urban Space and War: The Destruction and Reconstruction of Sarajevo, (Palgrave MacMillan, 2018), 97.

15. Ibid, 82.

16. John F. Burns, Sarajevo Paper Defies War by Staying in Print, (New York Times, 1992).

17. Robert Bevan, The Destruction of Memory: Architecture at War, (Reaktion Books, 2006), 121.

18. Ibid, 122.

19. Ibid, 122.

20. Mirjana Ristić, Architecture, Urban Space and War: The Destruction and Reconstruction of Sarajevo, (Palgrave MacMillan, 2018), 69.

21. Nigel C. Hunt, Memory, War and Trauma, (Cambridge University Press, 2010), 96.

22. Mirjana Ristić, Architecture, Urban Space and War: The Destruction and Reconstruction of Sarajevo, (Palgrave MacMillan, 2018), 65.

23. Ibid, 97.

THE BESIEGED CITY: THE STRENGTH OF RESISTANCE

24. Mirjana Ristić, Architecture, Urban Space and War: The Destruction and Reconstruction of Sarajevo, (Palgrave MacMillan, 2018), 108. 
25. Xavier Bougarel, Elissa Helms \& Ger Duijzings, The New Bosnian

Mosaic: Identities, Memories and Moral Claims in a Post-War Society, (Ashgate, 2007), 55.

26. Mirjana Ristić, Architecture, Urban Space and War: The Destruction and Reconstruction of Sarajevo, (Palgrave MacMillan, 2018), 116.

27. Ibid, 119.

28. Reif Larsen, Sarajevo's Enduring Optimism, (New York Times, 2015).

29. Ivana Maćek, Sarajevo Under Siege: Anthropology in Wartime, (University of Pennsylvania Press, 2009), 55.

30. Reif Larsen, Sarajevo's Enduring Optimism, (New York Times, 2015).

THE DIVERSE CITY: THE OTTOMAN EMPIRE

01. Ivan Lovrenović, Bosnia and Herzegovina, (Svjetlost, 1986).

02. Nermina Zagora \& Dina Samić, Sarajevo Lost in Translation?

Ideologies and Their Representational Spaces, (International

Journal of Architectural Research, 2014).

THE DIVERSE CITY: THE AUSTRO-HUNGARIAN MONARCHY

03. Nermina Zagora \& Dina Samić, Sarajevo Lost in Translation?

Ideologies and Their Representational Spaces, (International

Journal of Architectural Research, 2014).

04. Ibid.

THE DIVERSE CITY: THE SOCIALIST ERA

05. Ivan Lovrenović, Bosnia and Herzegovina, (Svjetlost, 1986).

06. Martino Stierli \& Vladimir Kulić, Toward a Concrete Utopia:

Architecture in Yugoslavia 1948-1980, (MoMa, 2018).

07. Ibid, 210.

08. Valerijan Zujo, Sarajevo, (Rabic Publisher, 2006). 
09. Nermina Zagora \& Dina Samić, Sarajevo Lost in Translation? Ideologies and Their Representational Spaces, (International Journal of Architectural Research, 2014).

10. Ivan Štraus, The Architecture of Bosnia \& Herzegovina 1945-1995 [Arhitektura Bosne i Hercegovine 1945-1995], (OKO, 1998).

11. Nermina Zagora \& Dina Samić, Sarajevo Lost in Translation? Ideologies and Their Representational Spaces, (International Journal of Architectural Research, 2014).

12. Ivan Lovrenović, Bosnia and Herzegovina, (Svjetlost, 1986).

ZAJEDNIČKI ŽIVOT

01. Gruia Badescu, Dwelling in the Post-War City Urban Reconstruction and Home-Making in Sarajevo, (Revue d'Etudes Comparatives Est-Ouest, 2015), 35-60.

02. Robert Bevan, The Destruction of Memory: Architecture at War, (Reaktion Books, 2006), 176.

03. Gruia Badescu, Dwelling in the Post-War City Urban Reconstruction and Home-Making in Sarajevo, (Revue d'Etudes Comparatives Est-Ouest, 2015), 35-60.

04. Robert Bevan, The Destruction of Memory: Architecture at War, (Reaktion Books, 2006), 85.

05. Ibid.

CULTURAL PROFILE

01. Mirza Redzić, Made in War (Boomed in Peace): The Sarajevo Film Festival, (European Cultural Foundation, 2014).

02. Ibid.

03. Ibid.

04. Kenneth Turan, Sundance to Sarajevo: Film Festivals and the World they Made, (University of California Press, 2002), 97. 
05. Mirza Redzić, Made in War (Boomed in Peace): The Sarajevo Film Festival, (European Cultural Foundation, 2014).

SOCIAL DIALOGUE

01. Steven Galloway, The Cellist of Sarajevo, (Vintage Canada, 2009), 35.

02. Reif Larsen, Sarajevo's Enduring Optimism, (New York Times, 2015).

03. Aleksandar Hemon, Mapping Home: Learning a New City,

Remembering the Old, (The New Yorker, 2011).

04. Brad Cohen, The Complicated Culture of Bosnian Coffee, (BBC

Travel, 2014).

SKENDERIJA REACTIVATED

01. Djordje Krajisnik \& Mejrem Zatrić, Skenderija’s Case: Urbicide or Investment? [Slučaj Skenderija - Urbicid ili Investicija?], (Oslobođjenje, 2018).

02. Galen Lamphere-Englund, Rebuilding Sarajevo, (The Aleppo Project, 2015).

03. Amer Kapo, Skenderija Will Live a Full Life [Skenderija će Živjeti Punim Životom], (Radiosarajevo.ba, 2018).

CONCLUSION

01. David Littlefield, Saskia Lewis \& Alain de Botton, Architectural Voices: Listening to Old Buildings, (Wiley, 2007), 15.

02. Ivan Štraus, The Architecture of Bosnia \& Herzegovina 1945-1995

[Arhitektura Bosne i Hercegovine 1945-1995], (OKO, 1998). 


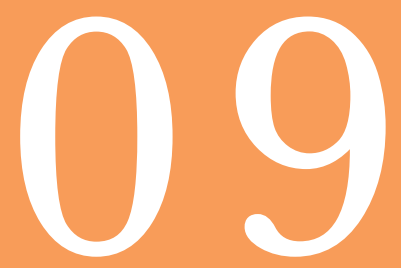

// LIST OF ILLUSTRATIONS 


\section{LIST OF ILLUSTRATIONS}

// THE SCARS OF SARAJEVO \& SKENDERIJA'S PLACE

PREFACE

Figure 1:

Photograph: By author. Looking down Strossmajerova Street, off Ferhadija Street in Sarajevo's Austro-Hungarian built centre, 2018.

Figure 2:

Photograph: Bahra Paralija (mother). Windows covered with plastic after shelling breaks all the glass, apartment in Voljničko Polje, 1995.

Figure 3:

Photograph: Bahra Paralija (mother). Playing on "Salvation Road" in Dolac Malta outside apartment (author on bike and sister above). Sarajevo, 1993.

Figure 4:

Photograph: Bahra Paralija (mother). Author celebrates third birthday in Makarska, Croatia after escaping the war. Makarska, 1995.

Figure 5:

Photograph: Mirjana Berry. First day in Canada. Toronto, 1995.

Figure 6:

Photograph: Dragan Tomić-Bešlić (father). Dragan's personal belongings, lost during the siege, are seen in a display case at the Historical Museum of Bosnia \& Herzegovina. His wallet, identity card and cigarette case haven't been seen for over twenty years. Sarajevo, 2018. 
Figure 7:

Graphic: By author. Map of Sarajevo highlighting the event locations of the 1984 Winter Olympic Games, hosted in Sarajevo.

Figure 8:

Photograph: David Madison. Opening ceremony of 1984 Winter Olympic Games, held at Koševo Stadium.

Figure 9:

Photograph: Skenderija.ba Archives. 1984 Winter Olympic Games metal ceremonies, held on the plateau of KSC Skenderija. Dom Mladih [Youth House] is seen in the back.

Figure 10:

Photograph: "All Roads Lead to Sarajevo" [Svi Putevi Vode u Sarajevo] newspaper article. Source: https://www.olympic.org/sarajevo-1984

THE BESIEGED CITY: A LANDSCAPE OF FEAR

Figure 11:

Graphic: By author. Map of Sarajevo under siege.

Figure 12:

Photograph: Gabriel Bouys. Two woman walking down the street famously known as Sniper's Alley, 1994. Source: https://www.cnn.com/travel/ article/sarajevo-holiday-inn/index.html

Figure 13:

Photograph: Danilo Krstanović. A sign reading "Pazi! Snajper" [Caution! Sniper] as civilians run across Sniper's Alley, 1993. 
Figure 14 \& 15:

Photograph: Michael Stravato. On the way home through Sniper's Alley. Sarajevo, 1993.

Figure 16:

Photograph: Mikkel Ostergaard. Sarajevo's Marijin Dvor in July 1992.

Figure 17, 18, 19 \& 20:

Photograph: Tom Stoddart. Sarajevans either running, or waiting to run across Sniper's Alley between the years of 1992-1995.

Figure 21:

Photograph: Unknown photographer. Sarajevans taking shelting behind a UN armoured vehicle while cross a portion of Sniper's Alley. Source: https: / / www.facebook.com/pg/Sarajevo-Under-Siege-92-96-252027648183188/ photos/?tab=albums

Figure 22:

Photograph: Unknown photographer. Bosnian soldiers. Source: https:// www.facebook.com/pg/Sarajevo-Under-Siege-92-96-252027648183188/ photos $/$ ?tab=albums

Figure 23:

Photograph: Gilles Peress. Sarajevo’s Marijin Dvor in 1993.

Figure 24:

Photograph: Paul Lowe. Running for your life, Sniper's Alley in 1992.

Figure 25 \& 26:

Photograph: Unknown photographer. Depicting the resilience of children living through a war childhood. Source: https://www.facebook.com/pg/ Sarajevo-Under-Siege-92-96-252027648183188/photos/?tab=albums 
Figure 27:

Photograph: Heldur Netocny. Depicting the resilience of kids living through a war childhood. Date unknown.

Figure 28:

Photograph: Mikkel Ostergaard. A little girl stands beside a UN soldier in Sarajevo, 1992.

Figure 29:

Photograph: Laurent Rebours. A father's hands press against the window, as his wife and son escape besieged Sarajevo to a safe city. November 1992. Source: https://www.theatlantic.com/photo/2012/04/20-years-since-thebosnian-war/100278/

Figure 30:

Photograph: Teun Voeten. Depicting the resilience of kids living through a war childhood, playing with rubble. July 1993.

Figure 31:

Photograph: Unknown photographer. Depicting the resilience of children living through a war childhood. Source: https://www.facebook.com/pg/ Sarajevo-Under-Siege-92-96-252027648183188/photos/?tab=albums

Figure 32:

Photograph: Mirza Ajanovic. Depicting the resilience of children living through a war childhood. Central Sarajevo, 1992.

Figure 33:

Photograph: Odd Andersen. Chilredn play on abandoned tank and rubble in the completely destroyed Serb held neighbourhood of Grbavica, after the ordered ceasefire. April 1996. 
Figure 34:

Photograph: Tom Stoddart. Kids play basketball beside the burned down UNIS towers in central Sarajevo. 1992.

Figure 35:

Photograph: Photographer unknown. Obala Street at Skenderija bridge, running along the Miljacka River was completely destroyed because of its proximity to the front line during the siege. 1993.

Figure 36:

Photograph: Unknown photographer. Depicting the resilience of children living through a war childhood. Source: https://www.facebook.com/pg/ Sarajevo-Under-Siege-92-96-252027648183188/photos/?tab=albums

Figure 37:

Photograph: Ron Haviv. Men huddle together after shots are fired during the Peace Demonstration in Marijin Dvor, Sarajevo, on April 6, 1992. This is considered the official start to the Bosnian war. Source: https:// www.theatlantic.com/photo/2012/04/20-years-since-the-bosnianwar/100278/

THE BESIEGED CITY: RE-APPROPRIATING MEMORY

Figure 38:

Photograph: George Gobet. UNIS Twin Towers burn in central Sarajevo, along Sniper's Alley. June 8, 1992. Source: https: / /www.rferl.org/a/twentyfive-years-on-from-the-siege-of-sarajevo/28407397.html

Figure 39:

Photograph: Photographer unknown. Elektroprivreda Building goes up in flames from Serb attack. 1992. Source: arhiva/oslobodjenje.ba 
Figure 40:

Photograph: Photographer unknown. Vijećnica goes up in flames after Serb attack. August 25, 1992. Source: sarajevo-x.com/arhiva

Figure 41:

Photograph: Photographer unknown. UN armour vehicle patroling Sniper's Alley with the demolished Oslobođenje Building in the back. November, 1995. Source: https://www.facebook.com/pg/Sarajevo-UnderSiege-92-96-252027648183188/photos/?tab=albums

Figure 42:

Photographer: Haris Hasanbegović. A wounded city merging with the new Sarajevo City Centre (SCG) in behind it. 2018.

THE BESIEGED CITY: THE STRENGTH OF RESISTANCE

Figure 43 \& 44:

Photograph: Christian Marechal. Sarajevans cut trees outside in order to burn as firewood. Mother and daughter going to collect water with their makeshift carrier. Winter, 1993.

Figure 45 \& 46:

Photograph: Photographer unknown. Sarajevans on route to collect clean drinking water from the Sarajevo Brewery - one of the only sites throughout the siege that had a supply of clean water. Many would walk for several kilometers, dodging snipers the entire way.

Source: https://www.facebook.com/pg/Sarajevo-Under-

Siege-92-96-252027648183188/photos/?tab=albums

Figure 47:

Photograph: Teun Voeten. Sarajevans bringing clean drinking water back home. This bridge used to have wood planks, all of which were stolen and used as firewood. July 1993. 
Figure 48:

Photograph: Zoran Kanlić. Woman cooking on her balcony, using a homemade stove that was made with a tin can. May 23, 1993. Source: https:// link.springer.com/content/pdf/10.1007/s13753-012-0004-4.pdf

Figure 49:

Photograph: Photographer unknown. Sarajevans walking up 'Put Života', known as 'Road of Salvation' behind shipping crates as barriers.

Source: https://www.facebook.com/pg/Sarajevo-Under-

Siege-92-96-252027648183188/photos/?tab=albums

Figure 50 \& 51:

Photograph: Photographer unknown. Different variations of soft barriers, in central Sarajevo, Titova Street. Source: https://www.facebook.com/pg/ Sarajevo-Under-Siege-92-96-252027648183188/photos/?tab=albums

Figure 52 \& 53:

Photograph: Photographer unknown. Different variations of hard barriers, in Novo Sarajevo, where the distances between buildings were larger and required more. Source: https://www.facebook.com/pg/Sarajevo-UnderSiege-92-96-252027648183188/photos/?tab=albums

Figure 54:

Photograph: Tom Stoddart. Meliha Varešanović defiantly walks to work in the dangerous suburb of Dobrinja, during the siege. This became the most famous photo throughout the siege, signifying 'You will never defeat us'.

Source: http://www.sarajevotimes.com/meliha-varesanovic-womanbrought-glamor-war-zone/

Figure 55:

Photograph:Jerome Delay. Participants in the Miss Besieged Sarajevo 1993 beauty pageant line up on stage, holding banner 'Don't Let Them Kill Us'. Source: https://www.theatlantic.com/photo/2012/04/20-years-since-thebosnian-war/100278/ 
Figure 56:

Photograph: Photographer unknown. Vedran Smailović plays his cello at the location of the bread line massacre, under the threat of snipers in Sarajevo. Ferhadija Street, 1992.

Source: https://www.cnn.com/videos/world/2012/04/06/natpkg-

bosnian-cello-player-remembers-sarajevo.cnn

THE DIVERSE CITY: THE OTTOMAN EMPIRE

Figure 57:

Graphic: By author. General map of Sarajevo showing the city's geography and different areas throughout its historic development. Source of map used as underlay: https://legacy.lib.utexas.edu/maps/bosnia.html

Figure 58:

Graphic: By author. Expansion map of Sarajevo.

Figure 59 \& 60:

Photograph: Photographer unknown. Sarajevo's Baščaršija in the Ottoman Empire. Source: arhiva/oslobodjenje.ba

Figure $61 \& 62$ :

Photograph: Dragoljub Zamurović. View of an Ottoman mahala, and view of Sarajevo's old Ottoman town. Source: Zujo, Valerijan. Sarajevo. Rabic Publisher. Sarajevo. Print. 2006.

Figure 63:

Photograph: Historic map of Sarajevo's Baščaršija in the Ottoman Empire. Shows a typical Ottoman town with an irregular street pattern. Source: http://tristotrojka.org/the-relationship-of-architecture-and-politicsthroughout-the-history-of-bh/ 
Figure 64 \& 65:

Photograph: Photographer unknown. Austro-Hungarian architecture along the river, on Obala Street, and Titova Street. Source: https://www. naimlogic.com/BH-Old-Postcards/Sarajevo/i-XWj79hs

Figure 66:

Photograph: Nedim Džaka. Sacred Heart Cathedral located on Ferhadija Street in Sarajevo's city centre. Traces of Austro-Hungarian architecture seen in background. 2016.

Figure 67:

Photographer: Zara Zun. Where Titova Street meets Ferhadija Street. 2016.

THE DIVERSE CITY: THE SOCIALIST ERA

Figure 68:

Photograph: Nedim Džaka. Otoka neighbourhood of Novo Sarajevo, in the socialist expansion of the city. 2017.

Figure 69:

Photograph: Dragoljub Zamurović. Sarajevo's socialist residential buildings. Source: Zujo, Valerijan. Sarajevo. Rabic Publisher. Sarajevo. Print. 2006.

Figure $70 \& 71$ :

Photograph: Chris Leslie. Sarajevo's socialist built residential buildings in Novo Sarajevo neighbourhood. 2000.

Figure 72:

Photograph: Photographer unknown. Plateau at Skenderija in its early years. Source: http://skenderija.ba/index.php/home/galerija/galerijaarhiva 
Figure 73:

Photograph: Photographer unknown. Kino Cinema was the most popular cinema, located beside the socialist Sarajka. Source: arhivsa.ba

Figure 74:

Photograph: Photographer unknown. Socialist built department store called Sarajka. Source: arhivsa.ba

Figure 75:

Photograph: Dragoljub Zamurović. Several generations playing chess at Trg Oslobođenje, located off of Ferhadija Street. Source: Zujo, Valerijan. Sarajevo. Rabic Publisher. Sarajevo. Print. 2006.

Figure 76:

Graphic: By author. Timeline highlighting most prominent periods within Sarajevo's history.

A CULTURAL PROFILE

Figure 77:

Photograph: Mirza Redžić. Poster for the first ever Sarajevo Film Festival, titled "After the End of the World." Source: https: / / www.culturalfoundation. eu/library/mirza-redzic-sff-essay

Figure 78 \& 79:

Photograph: Kenneth Turan. A bombed out theatre in the city's centre after the siege of Sarajevo. A banner promoting the first post ceasefire Sarajevo Film Festival. Source: Turan, Kenneth. Sundance to Sarajevo: Film Festivals and the World they Made. University of California Press. Print. 2002.

Figure 80 \& 81:

Photograph: Photographer unknown. Outdoor, open-air theatre space used 
by the Sarajevo Film Festival - in a bombed out playground in Sarajevo's city centre. Entrance of the National Theatre during the festival. Source: https://www.instagram.com/sarajevofilmfestival/

A SOCIAL DIALOGUE

Figure 82:

Photograph: Nedim Džaka. View of Miljacka River and all its bridges as seen from the Ottoman Old Town of the city. 2017.

Figure 83, 84 \& 85:

Photograph: Damir Hajdarbašić. Fall on Vilsonovo Šetalište in Sarajevo. Source: https://sarajevski.ba/foto-jesenje-boje-vilsonovog-setalista/41772

Figure 86:

Photograph: By author. Looking down Strossmajerova Street, off Ferhadija Street, showing sidewalk cafe culture. 2018.

Figure $87 \& 88$ :

Photograph: Dragoljub Zamurović. View onto Ferhadija Street. Ferhadija connects to Titova Street, view from above.

Source: Zujo, Valerijan. Sarajevo. Rabic Publisher. Sarajevo. Print. 2006.

Figure 89:

Photograph: Patrick Horton. Looking down the Copper trade street in the old Ottoman town of Sarajevo. 2014. Source: http://www.bbc.com/travel/ story/20140707-the-complicated-culture-of-bosnian-coffee

Figure 90:

Photograph: Rico Fabello. Looking down another narrow street in the old Ottoman town of Sarajevo. 2018. Source: https://ciaofabello.com/ blog/2018/1/two-weeks-in-bosnia-croatia-sarajevo-bosnia 
Figure 91, 92 \& 93:

Photograph: Photographer unknown. Sarajevo's sidewalk cafe culture.

Images in Ottoman old town and Ferhadija street. Source: Google Images.

Figure 94:

Photograph: Photographer unknown. Traditional Bosnian coffee serving. Source: Google Images.

Figure 95:

Graphic: By author. Map of key pedestrian zones in Sarajevo.

EVOLUTION OF SKENDER-BEY

Figure 96:

Graphic: By author. Diagram of Skenderija's site evolution.

Figure 97 \& 98:

Photograph: Photographer unknown. Skender-Bey Mosque with Skender Bridge, connecting the other side where the caravansary was located.

Source: http://skenderija.ba/index.php/home/galerija/galerijaarhiva

Figure 99:

Photograph: Photographer unknown. Image of Skender-Bey's soccer field after Austro-Hungarian development occurred throughout surrounding area. Source: http://skenderija.ba/index.php/home/galerija/galerijaarhiva

TITO'S SKENDERIJA

Figure $100 \& 101$ :

Photograph: Photographer unknown. KSC Skenderija upon its completion. President Josip Broz Tito (second from right) on the ceremonious opening. Source: http://skenderija.ba/index.php/home/galerija/galerijaarhiva 
Figure 102 - 113:

Photograph: Photographer unknown. Images of numerous events held at KSC Skenderija from the 1970s and 1980s.

Source: http://skenderija.ba/index.php/home/galerija/galerijaarhiva

Figure 114, 115 \& 116:

Photograph: Photographer unknown. Historic KSC Skenderija plateau. Source: http://skenderija.ba/index.php/home/galerija/galerijaarhiva

OLYMPIC SYMBOLISM

Figure 117:

Photograph: Photographer unknown. Aerial image of KSC Skenderija with the addition of Ledena Dvorana for the 1984 Winter Olympic Games. Source: http://skenderija.ba/index.php/home/galerija/galerijaarhiva

Figure 118:

Graphic: By author. Diagram illustrating Sarajevo's 'ZeTra' green passage; inteded to establish an Olympic corridor during the 1984 games.

Figure 119:

Photograph: Photographer unknown. Sarajevans gather and cheer on the plateau during the games. Source: http://skenderija.ba/index.php/home/ galerija/galerijaarhiva

Figure 120:

Photograph: Carey Wilson. Image of hockey game held at Leden Dvorana during the 1984 Winter Olympic games.

Figure 121:

Photograph: Photographer unknown. 1984 Winter Olympic Games Medal ceremony on Skenderija plateau. Source: http://skenderija.ba/index.php/ home/galerija/galerijaarhiva 
Figure 122:

Photograph: Mirjana Ristić. Snipers view from the hills above Skenderija, onto Marijin Dvor neighbourhood. Source: Ristić, Mirjana. Architecture, Urban Space and War: The Destruction and Reconstruction of Sarajevo. Palgrave MacMillan. Print. 2018.

Figure 123 \& 124:

Photograph: Photographer unknown. Skenderija being used as the United Nations base station for humanitarian aid during the siege. Source: https:/ / www.facebook.com/pg/Sarajevo-Under-Siege-92-96-252027648183188/ photos $/$ ?tab=albums

Figure 125:

Graphic: By author. Timeline highlighting Skenderija's functions and uses throughout its lifetime.

SITE IMPRESSIONS: CONDITIONAL ASSESSMENT

Figure 126:

Photograph: By author. Image of Ledena Dvorana's shelled roofless facade. Olympic rings cast within its bare concrete. 2018.

Figure 127:

Photograph: Photographer unknown. Aerial image of Skenderija in 2017 during the plateau renovations. Source: Klix.ba

Figure 128 - 163:

Photographs: By author. Selection of images depicting Skenderija's varying site conditions. These images show Skenderija's separate buildings, derelict areas, sections of renovated and damaged plateau, and city initiatives to increase activity on plateau through seasonally changing activities. Images taken on site study trip in fall 2018. 
Figure 164:

Graphic: By author. Map of Sarajevo highlighting building programs within the organization of the city.

Figure 165:

Graphic: By author. Map of Sarajevo highlighting points of sporting, arts, cultural, social interests within the city.

\section{SKENDERIJA REACTIVATED}

Figure 166:

Graphic: By author. Site study map highlighting points of sporting, arts, cultural, social interests within a $2.0 \mathrm{~km}$ radius of the thesis site.

\section{SKENDERIJA TAKES CENTRE STAGE}

Figure 167:

Graphic: By author. Mind mapping of programmatic possibilities of thesis site. Sketch of cultural divisions included on site.

Figure 168:

Graphic: By author. Conceptual sketches of Ledena Dvorana proposal.

Figure $169 \& 170$ :

Graphic: By author. Current map of facilities used during the Sarajevo Film Festival and the proposed rerouting of facilities used during the SFF.

Figure 171:

Graphic: By author. Site study map highlighting possible walking paths 
throughout the site and the city, connection areas of cultural, sporting, commercial, artistic and social interests within a $2.0 \mathrm{~km}$ radius of the thesis site. Sarajevo Film Festival facilities are highlighted in faint red radii.

Figure 172:

Graphic: By author. List of all confirmed and scheduled events and festivals happening in Sarajevo, BiH from April 15th to June 30th, 2019. Dates and events source: https://allevents.in/sarajevo

Figure 173:

Graphic: By author. Sketch diagram of plateau in potential opportunities of seasonally changing activities and uses.

Figure 174:

Graphic: By author. New proposed site plan of KSG Skenderija. Showing typical usage of public spaces throughout the plateau, highlighting areas of intended density.

Figure 175:

Graphic: By author. North-south section looking west. Cut through Ledena Dvorana and the plateau, highlighting important viewpoints through the site, into the site, and out of the site into the city.

Figure 176:

Graphic: By author. Closer look within Ledena Dvorana, cutting through the new theatre space. Flexible flooring within the theatre space allows for organized events, and raised seating for cinema viewings. Schedule lists hang through the double height balcony on fabric sheeting, reminiscent of barriers created throughout the resilience of war.

Figure 177:

Graphic: By author. Diagrammatic depiction of the new proposed lantern atop Ledena Dvorana's shell as a beacon of light through the valley of Sarajevo. 
Figure 178:

Graphic: By author. Proposed north elevation, looking toward the main entrance of Ledena Dvorana. The new addition with its light glazing facade, appears as if it is floating above Ledena Dvorana's roofless shell, lighting up against the mountainous backdrop during the evening.

Figure 179:

Graphic: By author. Programmatic division plan of thesis proposal. Showing typical plan of summer festival or event occuring on plateau, with tickets being purchased from the Ledena Dvorana box office and high density of visitors throughout.

Figure 180:

Graphic: By author. Timeline of potential seasonal events occuring at KSC Skenderija and its surrounding plateau, ranging in themes of culture, film, art, sporting, commercial and social, in addition to the already existing fair culture.

Figure 181:

Graphic: By author: Afternoon vignette of the proposed coffee corridor located between Mirza Delibašić Dvorana and Ledena Dvorana. Looking towards the plateau, visitors exit the box office through Ledena Dvorana and stop for a look through vendor stands and coffee.

Figure 182:

Graphic: By author. Evening vignette of the proposed plateau in the winter months. With Ledena Dvorana's lantern visibly shining, the central plateau houses a temporal public skating rink with terracotta weather canopies covering an adjacent seating area.

Figure 183:

Photograph: By author. Image of KSC Skenderija's main hall, Mirza Delibašić Dvorana, during sunset. Taken during site study trip in fall 2018. 

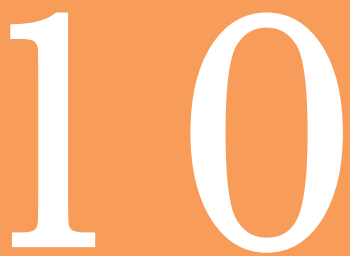

// BIBLIOGRAPHY 


\section{BIBLIOGRAPHY}

// TEXT CITATIONS

Abagi, Maya. How to Preserve and Protect the Modernist Symbol of Sarajevo [Kako Očuvati I Zaštititi Modernistički Simbol Sarajeva].

Oslobođjenje. Web. February 15, 2018.

https://www.oslobodjenje.ba/o2/kultura/kako-ocuvati-i-zastititi-

modernisticki-simbol-sarajeva

Badescu, Gruia. Dwelling in the Post-War City Urban Reconstruction and Home-Making in Sarajevo. Revue d'Etudes Comparatives Est-Ouest, vol. 46, no. 4, pp. 35-60. 2015

Bevan, Robert. The Destruction of Memory: Architecture at War. Reaktion Books. Print. 2006.

Bogunović, Duško. Against Demolition of Skenderija [Tekst Protiv Rušenja Skenderije]. Asocijacija Arhitekata u Bosni I Hercegovini. Web. Februrary 28, 2018.

https://aabh.ba/tekst-protiv-rusenja-skenderije-prof-dr-dusko-bogunovic/

Bougarel, Xavier and Helms, Elissa and Duijzings, Ger. The New Bosnian Mosaic: Identities, Memories and Moral Claims in a Post-War Society.

Ashgate, Aldershot. Print. 2007.

Brand, Stewart. How Buildings Learn: What Happens After They're Built. Penguin Books. Print. 1995.

Burns, John F. Racing Through Snipers' Alley on Ride to Sarajevo. Web. New York Times Archives. September 26, 1992.

https://www.nytimes.com/1992/09/26/world/racing-through-snipersalley-on-ride-to-sarajevo.html

Burns, John F. Sarajevo Paper Defies War by Staying in Print. Web. New York Times Archives. October 7, 1992.

https://www.nytimes.com/1992/10/07/world/sarajevo-paper-defies-warby-staying-in-print.html 
Burns, John F. The Death of a City: Elegy for Sarajevo - a Special Report: A People Under Artillery Fire Manage to Retain Humanity. Web. New York Times Archives. June 8, 1992.

https://www.nytimes.com/1992/06/08/world/death-city-elegy-forsarajevo-special-report-people-under-artillery-fire-manage.html

Cohen, Brad. The Complicated Culture of Bosnian Coffee. Web. BBC Travel. July 16, 2014.

http://www.bbc.com/travel/story/20140707-the-complicated-culture-ofbosnian-coffee

Dizdarević, Zlatko. Sarajevo: A War Journal. Fromm International Publishing. New York City. Print. 1993.

Filipović, Zlata. Zlata’s Diary. Penguin Books. New York City. Print. 1993

France-Presse, Agence. Sarajevo's Wartime Tunnel Survives as Museum. New York Times. Web. 2004.

https://www.nytimes.com/2004/02/01/international/europe/sarajevoswartime-tunnel-survives-as-museum.html

Galloway, Steven. The Cellist of Sarajevo. Vintage Canada, 2009.

Gehl, Jan. Cities for People. Island Press. Washington, DG. Print. 2010.

Gjelten, Tom. Sarajevo Daily: a City and its Newspaper Under Siege. New York City. HarperCollins Publishers. Print. 1996.

Hemon, Aleksandar. Mapping Home: Learning a New City, Remembering the Old. New York City. The New Yorker. Web. 2011.

https://www.newyorker.com/magazine/2011/12/05/mapping-home

Hunt, G. Nigel. Memory, War and Trauma. Cambridge University Press. New York City. Print. 2010.

Husukić, Erna \& Zejnilović, Emina. The Environmental Aesthetics of Sarajevo: A City Shaped by Memory. Urbani Izziv: Vol. 28, No. 1. Web. 2017. 
https://www.researchgate.net/publication/317638535_The_ environmental_aesthetics_of_Sarajevo_A_city_shaped_by_memory

Jergović, Miljenko. Three Winter Days in Sarajevo or Lamenting Skenderija [Tri Zimska Dana u Sarajevu ili Lament nad Skenderijom]. Jutarnji Journal. Web. 2018.

https://www.jutarnji.hr/komentari/tri-zimska-dana-u-sarajevu-ili-lamentnad-skenderijom/6913977/

Kappler, Stefanie. Sarajevo's Ambivalent Memoryscape: Spatial Stories of Peace and Conflict. Memory Studies: Vol. 10, Article 2. Web. 2017. https://journals.sagepub.com/doi/10.1177/1750698016650484

Kapo, Amer. Skenderija Will Live a Full Life [Skenderija će Živjeti Punim Životom]. Radiosarajevo.ba. Web. February 24, 2018.

https://www.radiosarajevo.ba/vijesti/lokalne-teme/kapo-skenderija-cezivjeti-punim-zivotom/292100

Krajisnik, Djordje. Skenderija's Case: Urbicide or Investment? [Slučaj Skenderija - Urbicid ili Investicija?]. Oslobođjenje. Web. February 22, 2018.

https://www.oslobodjenje.ba/o2/kultura/slucaj-skenderija-urbicid-iliinvesticija

Kurspahić, Kemal. As Long As Sarajevo Exists. Pamphleteers Press. Connecticut. Print. 1997.

Lamphere-Englund, Galen. Rebuilding Sarajevo. The Aleppo Project. Web. 2015.

https://www.thealeppoproject.com/wp-content/uploads/2015/10/

Rebuilding-Sarajevo-Full-report-HD.pdf

Larsen, Reif. Sarajevo's Enduring Optimism. New York Times. Web. 2015. https://www.nytimes.com/2015/10/04/travel/sarajevo-tourism-history. html

Littlefield, David \& Saskia Lewis \& Alain de Botton. Architectural Voices: Listening to Old Buildings. Wiley. 2007. 
Lovrenović, Ivan. Bosnia \& Herzegovina. Svjetlost. Sarajevo. Print. 1986.

Maćek, Ivana. Sarajevo Under Siege: Anthropology in Wartime.

University of Pennsylvania Press. Philadelphia. Print. 2009.

Mehaković, Mirza. Mature Modern Legacy in Sarajevo - KSG

"Skenderija" [Naslijede Zrele Moderne u Sarajevu - KSC "Skenderija"].

Tristotrojka. Web. January 22, 2018.

http://tristotrojka.org/naslijede-zrele-moderne-u-sarajevu-ksc-skenderija/

Pilav, Armina. Before the War, War, After the War: Urban Imageries for

Urban Resilience. School of Doctorate Studies, University of IUAV of

Venice. Web. 2012.

https://link.springer.com/content/pdf/10.1007/s13753-012-0004-4.pdf

Redzić, Mirza. Made in War (Boomed in Peace): The Sarajevo Film

Festival. European Cultural Foundation. Web. 2014.

https://static1.squarespace.com/static/526e5978e4b0b83086alfede/

t/5947b00f2e69cf8223954e02/1497870355971/

Made $\% 2$ Bin $\% 2$ Bwar $\% 2$ B $\% 28$ boomed $\% 2$ Bin $\% 2$ Bpeace $\% 29 \% 2 B S F F . p d f$

Ristić, Mirjana. Architecture, Urban Space and War: The Destruction and Reconstruction of Sarajevo. Palgrave MacMillan. Print. 2018.

Ristić, Željko. The Relationship of Architecture and Politics Throughout the History of Bosnia \& Herzegovina. Tristotrojka. Web. 2018.

http://tristotrojka.org/the-relationship-of-architecture-and-politicsthroughout-the-history-of-bh/

Salihović, Hamdija. Art and the Art of Architecture [Arhitekt i Umjetnost Graditeljstva]. Arhitektonski Fakultet. Print. 2002.

Stierli, Martino \& Kulić, Vladimir. Toward a Concrete Utopia:

Architecture in Yugoslavia 1948-1980. MoMa, New York. Print. 2018.

Štraus, Ivan. New Bosnia \& Herzegovina Architecture [Nova Bosansko Hercegovačka Arhitektura]. Svjetlost. Print. 1977. 
Štraus, Ivan. The Architecture of Bosnia \& Herzegovina 1945-1995

[Arhitektura Bosne i Hercegovine 1945-1995]. OKO. Print. 1998.

Štraus, Ivan. 99 Architects of Sarajevo, 1930-1990 [99 Arhitekata

Sarajevskog Kruga 1930-1990]. OKO. Print. 2010.

Till, Karen. "Wounded cities: Memory-Work and a Place-Based Ethics of Care.” Political Geograpby Journal: Vol. 31, pg. 3-14. Web. 2012.

http://citeseerx.ist.psu.edu/viewdoc/

download?doi $=10 \cdot 1 \cdot 1 \cdot 823.443 \&$ rep $=$ rep $1 \&$ type $=$ pdf

Till, Karen; Kaufman, Emily; and Woodward, Christine L. "Place, Memory, and Archive: An Interview with Karen Till," disClosure: A Journal of Social Theory: Vol. 27, Article 4. 2018

https://uknowledge.uky.edu/disclosure/vol27/iss 1/4

Tomsky, Terri. From Sarajevo to 9/11: Travelling Memory and the Trauma Economy. Parallax, vol. 17, issue 4. Pg. 49-60. Print. 2011.

Turan, Kenneth. Sundance to Sarajevo: Film Festivals and the World they Made. University of California Press. Print. 2002.

Vuic, Jason. The Sarajevo Olympics: a History on the 1984 Winter Games. University of Massachusetts. Print. 2015.

Whyte, William H. The Social Life of Small Urban Spaces. Project For Public Spaces. New York City. Print. 1980.

Woods, Lebbeus. War and Architecture. Pamphlet Architectural 15. New York City. Princeton Architectural Press. Print. 1993.

Zagora, Nermina \& Samić, Dina. Sarajevo Lost in Translation? Ideologies and Their Representational Spaces. International Journal of Architectural Research (IJAR): Vol. 8, Issue 1. Web. 2014.

https://www.researchgate.net/publication/266374344_Sarajevo_lost_in_ transition_Ideologies_and_their_representational_spaces

Zujo, Valerijan. Sarajevo. Rabic Publisher. Sarajevo. Print. 2006. 


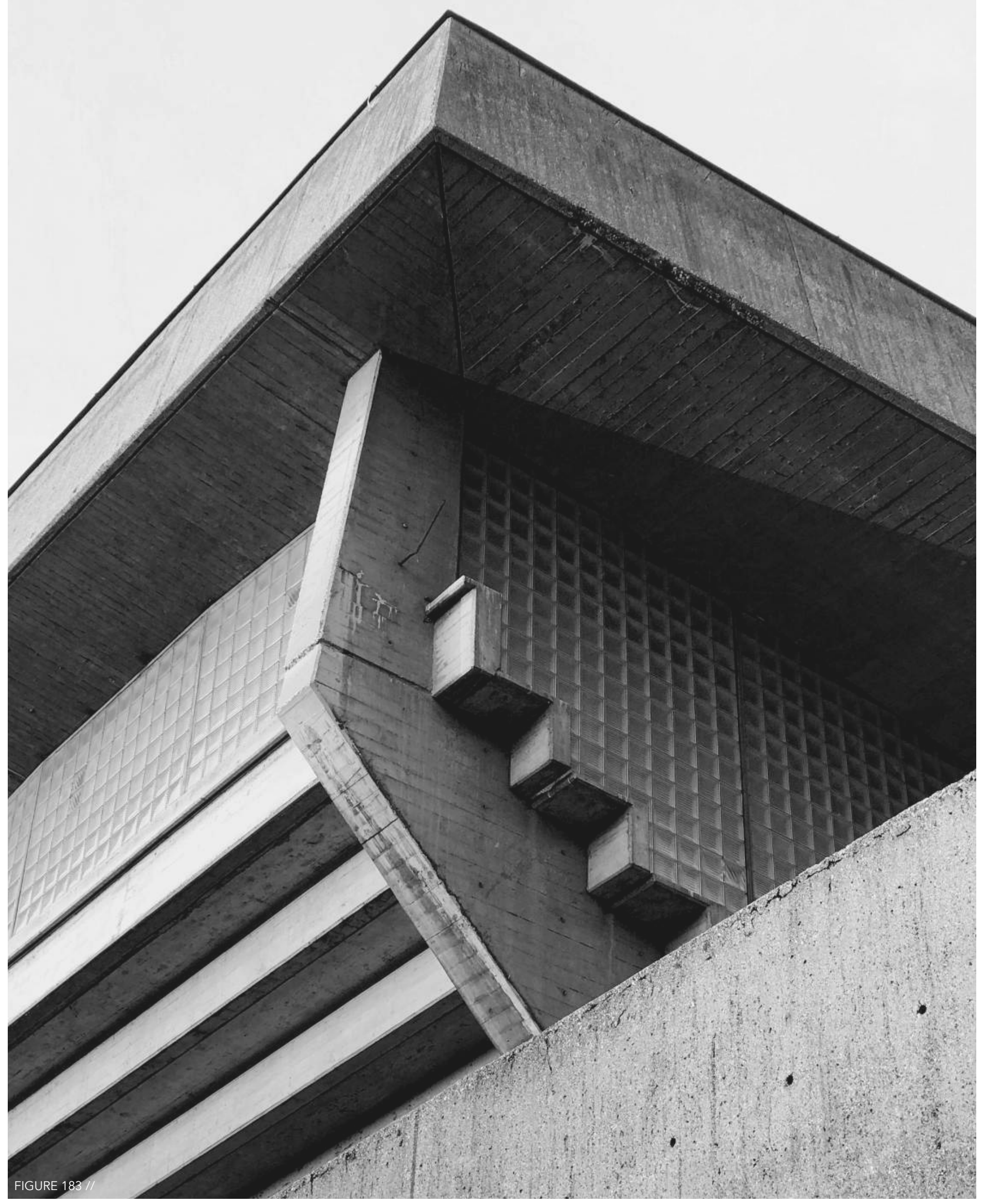

